\title{
Compilation of Geospatial Data for the Mineral Industries and Related Infrastructure of Latin America and the Caribbean
}

Open-File Report 2017-1079 



\section{Compilation of Geospatial Data for the Mineral Industries and Related Infrastructure of Latin America and the Caribbean}

By Michael S. Baker, Spencer D. Buteyn, Philip A. Freeman, Michael H. Trippi, and Loyd M. Trimmer III

Prepared in cooperation with the Inter-American Development Bank

Open-File Report 2017-1079 


\title{
U.S. Department of the Interior \\ RYAN K. ZINKE, Secretary
}

\section{U.S. Geological Survey William H. Werkheiser, Acting Director}

\author{
U.S. Geological Survey, Reston, Virginia: 2017
}

For more information on the USGS - the Federal source for science about the Earth, its natural and living resources, natural hazards, and the environment—visit http://www.usgs.gov or call 1-888-ASK-USGS.

For an overview of USGS information products, including maps, imagery, and publications, visit https://store.usgs.gov.

Any use of trade, firm, or product names is for descriptive purposes only and does not imply endorsement by the U.S. Government.

Although this information product, for the most part, is in the public domain, it also may contain copyrighted materials as noted in the text. Permission to reproduce copyrighted items must be secured from the copyright owner.

The material in this publication does not imply the expression of any opinion on the part of the Inter-American Development Bank (IDB) or the U.S. Geological Survey (USGS) concerning the legal status of any country, territory, city, or area or of its authorities, or concerning delimitations of its frontiers or boundaries, including disputed terrestrial or maritime claims. Moreover, the views expressed do not necessarily represent the decision or policy of IDB, nor does the use of trade names or commercial processes constitute endorsement.

Suggested citation:

Baker, M.S., Buteyn, S.D., Freeman, P.A., Trippi, M.H., and Trimmer, L.M., III, 2017, Compilation of geospatial data for the mineral industries and related infrastructure of Latin America and the Caribbean: U.S. Geological Survey Open-File Report 2017-1079, 87 p., 1 geodatabase and 1 geospatial PDF map, https://doi.org/10.3133/ofr20171079. 


\section{Preface}

This report describes the U.S. Geological Survey's ongoing commitment to its mission of understanding the nature and distribution of global mineral commodity supply chains by updating and publishing the georeferenced locations of mineral commodity production and processing facilities in Latin America and the Caribbean. The geodatabase and geospatial data layers described in this report create a new geographic information product in the form of a geospatial portable document format (PDF) map.

The material in this publication does not imply the expression of any opinion on the part of the Inter-American Development Bank (IDB) or the U.S. Geological Survey (USGS) concerning the legal status of any country, territory, city, or area or of its authorities, or concerning delimitations of its frontiers or boundaries, including disputed terrestrial or maritime claims. Moreover, the views expressed do not necessarily represent the decision or policy of IDB.

The contributions by non-USGS authors in this compilation, including geospatial data obtained from foreign governmental agencies or non-governmental organizations, are published as they were obtained. There may be more data in original datasets than presented in this compilation. The USGS makes no warranty, expressed or implied, concerning the accuracy of information contained in geographic data from non-USGS sources. Neither the USGS nor the U.S. Government shall be held liable for any damages resulting from the authorized or unauthorized use of these non-USGS data.

\section{Acknowledgments}

This report was sponsored by the Transparency Trust Fund of the Inter-American Development Bank (IDB), as part of the Bank's Extractive Sector Initiative (ESI), through the technical cooperation project entitled "Promoting Transparency and Sustainability in the Extractive Sector" (RG-T2496). On the basis of a Cooperative Research and Development Agreement (CRADA) signed by the IDB and the U.S. Geological Survey (USGS), the USGS has undertaken the project entitled "Compilation of geospatial data for the mineral industries and related infrastructure of Latin America and the Caribbean." 



\section{Contents}

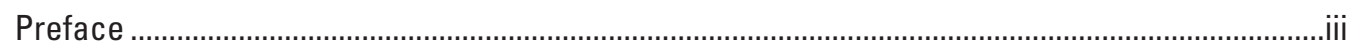

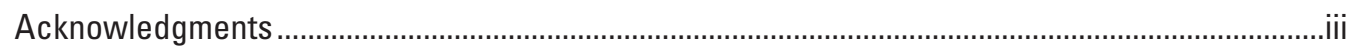

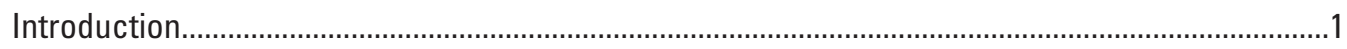

Historical background of USGS projects in Latin America and the Caribbean........................2

Latin America and the Caribbean—Current regional economic context .......................................2

Overview of current regional mineral production and reserve estimates.................................

Overview of the file geodatabase_LAC_Indust_Infra.gdb ….................................................

Geodatabase structure and overview of geospatial PDF map ..................................................

Overview of the file geodatabase — LAC_Indust_Infra.gdb ..........................................5

Overview of geospatial PDF map layout (layer navigation and visibility)..........................

Using the "Identify" and "Search" toolbars to access data feature class

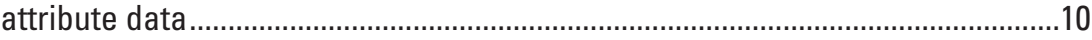

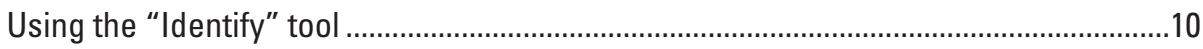

Using the "Search" function within the "Identify" tool...................................................13

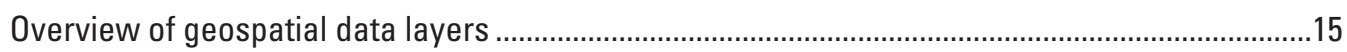

Mineral production sites and mineral processing facilities_- $A_{-}$MIN_FACIL

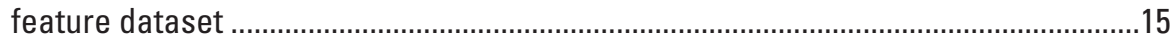

Mineral facilities: mines and processing facilities_-MINFAC_LAC feature class.........15

Oil and gas field center points_-OG_CENTER feature class ...........................................22

Mineral exploration and development sites and other mineral resources-

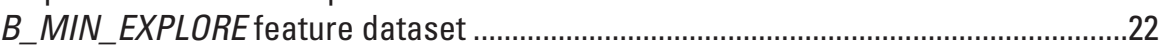

Mineral exploration and development sites_EXPLORE_LAC feature class ..................23

Coal occurrence areas_COAL_AREAS feature class ..................................................27

Undiscovered porphyry copper / polymetallic resources_CU_PORPH_TRACTS

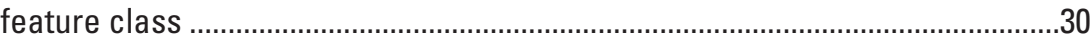

Energy infrastructure_C_ENERGY_INFRA feature dataset..................................................33

Electric power generating facilities_-POWER_LAC feature class...................................33

Oil and gas concession leasing areas_-OG_CONC_AREAS feature class ......................36

USGS petroleum provinces_PETRO_PROV feature class ...............................................36

Electric power transmission lines_-TRANSMISSION feature class.................................37

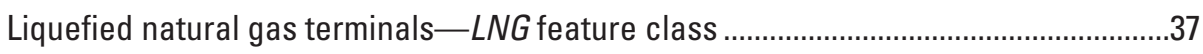

Oil and gas pipelines_-PIPELINES feature class.............................................................37

Oil and gas cumulative production and rank, recoverable proven plus probable hydrocarbon resources, and undiscovered hydrocarbon resources from IHS IEPD and USGS_D_IHS_USGS_OG_DATA feature dataset ................................39

Overview of hydrocarbon data from IHS IEPD and USGS-OG_COUNTRY and

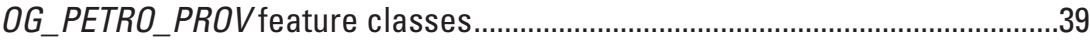

IHS IEPD data as displayed on the geospatial PDF map ................................................43

Additional information and data tables for OG_COUNTRY and OG_PETRO_PROV........43

Transportation infrastructure $-E \_T R A N S P O R \_I N F R A$ feature dataset.................................50

Railroads—RAIL feature class .............................................................................

Mineral commodity exporting ports_-PORTS_LAC feature class ................................50 
Cartographic elements-F_CARTO feature dataset ...........................................................54

Cartographic elements-CITIES, COUNTRY, LAC_ELEVATION, RIVERS, USA feature classes ............................................................................................

Geodatabase annotation groups_-G_ANNO feature dataset ...............................................5

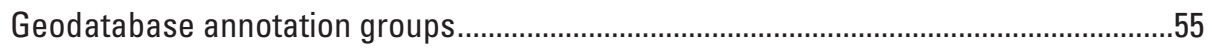

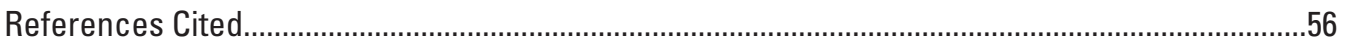

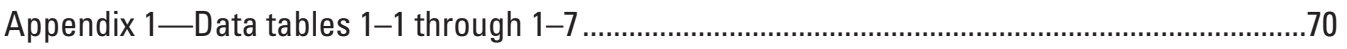

Appendix 2-Case study 1: Iron ore mining and transportation infrastructure

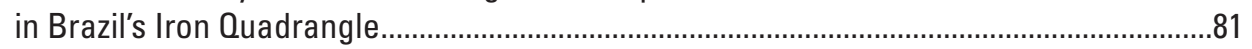

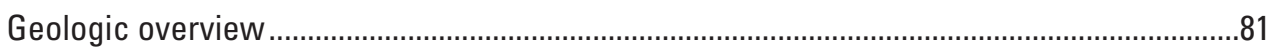

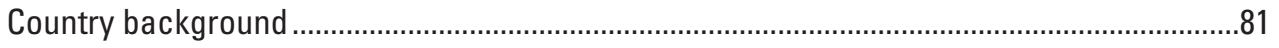

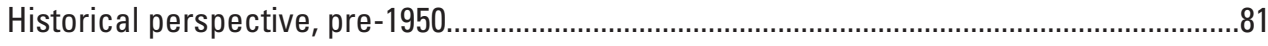

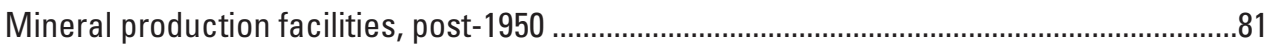

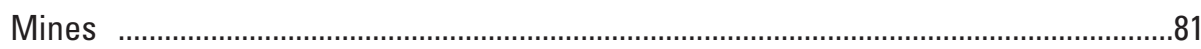

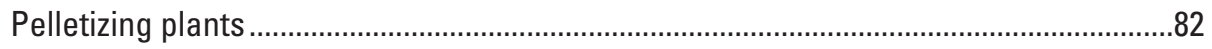

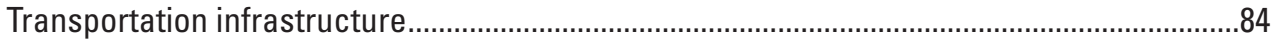

Appendix 3-Case study 2: Bauxite mining and alumina production in Jamaica ............................85

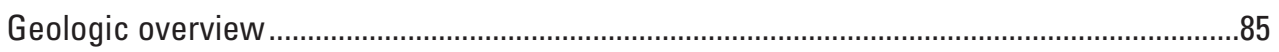

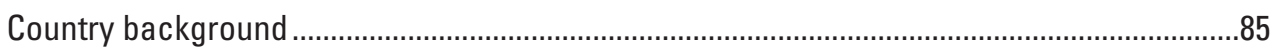

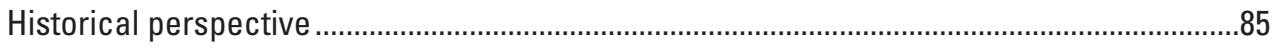

Mineral production facilities and transportation infrastructure .............................................86

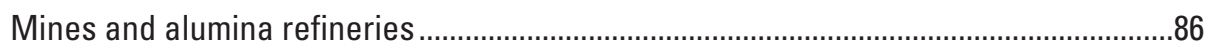

\section{Figures}

1. Annual GDP in constant (2015) million U.S. dollars for selected countries in Latin America and the Caribbean, 1990-2015.

2. File structure for $L A C_{-}$Indust_Infra.gdb geodatabase .....................................................

3. Screenshot of the geospatial PDF map, showing the left-hand layer navigation pane open.

4. List of feature dataset folders within the geospatial PDF map.

5. Expanded feature dataset folders showing individual data feature classes, or data layers, associated annotation group layers, or label layers, and the visibility controls within Adobe Reader

6. Screenshot of TerraGo Toolbar installed on a computer as a top menu, within Adobe Reader, showing several geospatial tools available for use

7. Screenshot of TerraGo Toolbar installed on a computer as an Extended menu on the right-hand side, within Adobe Reader, showing several geospatial tools available for use.

8. Screenshot of the "Identify" window, showing the "Search" function

9. Example results after performing a search with the "Search" function within the "Identify" window.

10. Expanded results of a search with the string "coal".

2-1. Overview map of iron ore mines, pelletizing plants, steel mills, and associated transportation infrastructure in the Iron Quadrangle, Minas Gerais, Brazil, 2015..........83

3-1. Overview map of bauxite mines and alumina refineries in Jamaica, 2016, showing associated transportation infrastructure. 


\section{Tables}

1. Examples of mineral-related cooperative projects between the U.S. Geological Survey and counterpart agencies in countries of Latin America and the Caribbean.......3

2. Globally significant nonfuel mineral commodity-producing countries in Latin America and the Caribbean, showing mineral commodity, 2015 preliminary production estimate by country, 2015 preliminary global production, and country production as percent share of global production

3. Countries ranking among the top three globally per nonfuel mineral commodity reserve estimate in Latin America and the Caribbean for 2015, by global rank and alphabetically by mineral commodity and country

4. Description of feature datasets within the file geodatabase LAC_Indust_Infra.gdb and supporting metadata files, as well as the related data folder name within the geospatial PDF map.

5. Geodatabase feature classes, geospatial PDF map data layers, and included attributes in the geospatial PDF map

6. List of attribute fields included in the geospatial PDF map, by data feature class..........13

7. Data feature classes within the $A \_M I N \_F A C I L$ feature dataset of the file geodatabase LAC_Indust_Infra.gdb.

8. Description of user-defined attribute fields in the mines and mineral processing facilities feature class MINFAC_LAC......

9. Total count of mineral facility data records in the MINFAC_LAC data feature class, by country

10. Data feature classes within the $B_{-}$MIN_EXPLORE feature dataset of the file geodatabase $L A C \_I n d u s t$ Infra.gdb.

11. Description of user-defined attribute fields in the mineral exploration and development sites feature class EXPLORE_LAC

12. Description of user-defined attribute field "PROJTYPE" in the mineral exploration and development sites feature class EXPLORE_LAC.

13. Total counts of selected mineral exploration and development sites in Latin America and the Caribbean, by country and project type, 2013-15, from the EXPLORE_LAC feature class

14. Number of coal occurrence areas in Latin America and the Caribbean, by coal rank and by country, from the COAL_AREAS feature class

15. Description of user-defined attribute fields in the coal occurrence areas feature class COAL_AREAS.

16. Undiscovered porphyry copper tracts assessed by the U.S. Geological Survey, containing the greatest estimated mean undiscovered metal content in the Caribbean and Central America, Mexico, and South America, 2008-10, from the CU_PORPH_TRACTS feature class..

17. Data feature classes within the $C_{-} E N E R G Y_{-}$INFRA feature dataset of the file geodatabase LAC_Indust_Infra.gdb.

18. Description of user-defined attribute fields in the electric power generating facilities data feature class POWER_LAC

19. Active liquefied natural gas terminals in Latin America and the Caribbean, 2016, from the $L N G$ data feature class

20. User-defined attribute fields in the OG_COUNTRY and OG_PETRO_PROV data feature classes. 
21. Cumulative production and recoverable proven plus probable resources of conventional hydrocarbon resources from oil fields, by country within Latin America and the Caribbean, from the OG_COUNTRY feature class.

22. Cumulative production and recoverable proven plus probable resources of conventional hydrocarbon resources from oil fields, by petroleum province within Latin America and the Caribbean, from the OG_PETRO_PROV feature class

23. Total mean volumes of undiscovered, technically recoverable conventional hydrocarbon resources from oil fields, by country within Latin America and the Caribbean, from the OG_COUNTRY feature class.

24. Total mean volumes of undiscovered, technically recoverable conventional hydrocarbon resources from oil fields, by petroleum province within Latin America and the Caribbean, from the OG_PETRO_PROV feature class

25. Description of user-defined attribute fields in the mineral commodity exporting ports feature class PORTS_LAC.

26. Summary statistics on mineral commodity exporting ports of Latin America and the Caribbean, 2010-12, from the PORTS_LAC feature class..

27. Mineral commodity-level statistics for mineral commodity exporting ports in Latin America and the Caribbean, 2010-12.

28. Annotation feature classes in the G_ANNO feature dataset and their corresponding map document feature class and corresponding geospatial PDF map layer, in alphabetical order by annotation feature class

1-1. Global reserve estimates (2015) and mine production (2014-15) of nonfuel mineral commodities for countries of Latin America and the Caribbean, by commodity and country.

1-2. Cumulative production and recoverable proven plus probable resources of conventional hydrocarbon resources from gas-only fields, by country within Latin America and the Caribbean

1-3. Cumulative production and recoverable proven plus probable resources of extra-heavy crude resources from oil fields, by country within Latin America and the Caribbean

1-4. Cumulative production and recoverable proven plus probable resources of unconventional hydrocarbon resources from oil fields, by country within Latin America and the Caribbean

1-5. Cumulative production and recoverable proven plus probable resources of conventional hydrocarbon resources from gas-only fields, by petroleum province within Latin America and the Caribbean...

1-6. Cumulative production and recoverable proven plus probable resources of extra-heavy crude from oil fields, by petroleum province within Latin America and the Caribbean

1-7. Cumulative production and recoverable proven plus probable resources of unconventional hydrocarbon resources from oil fields, by petroleum province within Latin America and the Caribbean .

2-1. Iron ore mining companies within the Iron Quadrangle region, Minas Gerais, Brazil 


\section{Conversion Factors}

International System of Units to U.S. Customary Units

\begin{tabular}{|c|c|c|}
\hline Multiply & $\mathrm{By}$ & To obtain \\
\hline \multicolumn{3}{|c|}{ Length } \\
\hline meter $(\mathrm{m})$ & 3.281 & foot $(\mathrm{ft})$ \\
\hline centimeter $(\mathrm{cm})$ & 0.3937 & inch (in.) \\
\hline millimeter $(\mathrm{mm})$ & 0.03937 & inch (in.) \\
\hline kilometer (km) & 0.6214 & mile (mi) \\
\hline \multicolumn{3}{|c|}{ Area } \\
\hline square kilometer $\left(\mathrm{km}^{2}\right)$ & 0.3861 & square mile $\left(\mathrm{mi}^{2}\right)$ \\
\hline \multicolumn{3}{|c|}{ Mass } \\
\hline kilogram $(\mathrm{kg})$ & 2.2046 & pound avoirdupois (lb) \\
\hline metric ton $(\mathrm{t})$ & 1.1023 & short ton \\
\hline \multicolumn{3}{|c|}{ Volume } \\
\hline cubic meter $\left(\mathrm{m}^{3}\right)$ & 6.2898 & $\begin{array}{l}\text { barrel (bbl; petroleum, } \\
1 \mathrm{bbl}=42 \text { gallons) }\end{array}$ \\
\hline cubic meter $\left(\mathrm{m}^{3}\right)$ & 35.3147 & cubic foot $\left(\mathrm{ft}^{3}\right)$ \\
\hline
\end{tabular}

U.S. Customary Units to International System of Units

\begin{tabular}{ccc}
\hline Multiply & By & To obtain \\
\hline & Volume & \\
\hline $\begin{array}{c}\text { barrel (bbl; petroleum, } \\
1 \text { bbl=42 gallons) } \\
\text { cubic foot }\left(\mathrm{ft}^{3}\right)\end{array}$ & 0.1590 & cubic meter $\left(\mathrm{m}^{3}\right)$ \\
\hline
\end{tabular}

\section{Datum}

Horizontal coordinate information is referenced to the World Geodetic System of 1984 (WGS 84). 


\section{Abbreviations}

\begin{tabular}{|c|c|}
\hline BCM & billion cubic meters \\
\hline CAP & Clarendon Alumina Production \\
\hline CFN & Companhia Ferroviária do Nordeste / Northeastern Railway Company \\
\hline CVRD & Companhia Vale do Rio Doce / Vale do Rio Doce Company \\
\hline DCW & Digital Chart of the World \\
\hline DEM & digital elevation model \\
\hline DOI & U.S. Department of the Interior \\
\hline DOS & U.S. Department of State \\
\hline LAC & Economic Commission for Latin America and the Caribbean \\
\hline EEZ & exclusive economic zone \\
\hline EFVM & Estrada de Ferro Vitória a Minas / Vitória-Minas Railway \\
\hline ENUD & estimated number of deposits \\
\hline FA & Ferrocarriles Argentinos S.A. / Argentine Railroads \\
\hline FCA & Ferrovia Centro-Atlantica S.A. / Atlantic Central Railroad \\
\hline $\mathrm{PP}$ & gross domestic product \\
\hline GIS & geographic information system \\
\hline $\mathrm{OR}$ & gas-to-oil ratio \\
\hline$G$ & billion metric tons \\
\hline$B$ & Inter-American Development Bank \\
\hline IEPD & International exploration and production database (IHS Markit) \\
\hline IH & Information Handling Services \\
\hline JBI & Jamaica Bauxite Institute \\
\hline JBM & Jamaica Bauxite Mining \\
\hline LAC & Latin America and the Caribbean \\
\hline IG & liquefied natural gas \\
\hline LSIB & Large-Scale International Boundary \\
\hline LT1 & less than one unit \\
\hline MCM & million cubic meters \\
\hline Mt & million metric tons \\
\hline N & megawatt \\
\hline NA & data not available or not applicable \\
\hline th. & The Netherlands \\
\hline & National Geospatial-Intelligence Agency (U.S.) \\
\hline
\end{tabular}




$\begin{array}{ll}\text { NGL } & \text { natural gas liquids } \\ \text { NMIC } & \text { National Minerals Information Center (U.S. Geological Survey) } \\ \text { PDF } & \text { portable document format } \\ \text { RFFSA } & \text { Rede Ferroviária Federal S.A. / Federal Railroad Network } \\ \text { RPP } & \text { recoverable proven plus probable resources } \\ \text { TOE } & \text { total oil equivalent } \\ \text { U.K. } & \text { United Kingdom } \\ \text { U.S. } & \text { United States } \\ \text { USAID } & \text { U.S. Agency for International Development } \\ \text { USGS } & \text { U.S. Geological Survey } \\ \text { W } & \text { data withheld to protect proprietary information } \\ \text { WPI } & \text { World Port Index }\end{array}$





\title{
Compilation of Geospatial Data for the Mineral Industries and Related Infrastructure of Latin America and the Caribbean
}

\author{
By Michael S. Baker, Spencer D. Buteyn, Philip A. Freeman, Michael H. Trippi, and Loyd M. Trimmer III
}

\section{Introduction}

The U.S. Geological Survey (USGS) compiles information on the location of mineral commodity extraction and processing facilities and analyzes their distribution worldwide to further understand the spatial characteristics of mineral commodity supply chains. The extractive mineral industries, including both fuel and nonfuel mineral commodities and resources, consist of any operations that remove aggregates, hydrocarbons, metals, and minerals from the earth. Examples of extractive processes used at mines and mineral production sites include oil and gas drilling and extraction, mining, mineral beneficiation and concentration, dredging, and quarrying, with examples of downstream processing facilities including petroleum refineries, metal refineries and smelters, and industrial mineral plants, such as those for cement.

The National Minerals Information Center (NMIC) of the USGS collects, analyzes, and disseminates information on a monthly, quarterly, and annual basis for more than 90 nonfuel mineral commodities in more than 180 countries, with information on fuel minerals included in regularly published country profiles. The NMIC performs analytical studies that address topical issues related to the availability of, the supply for, and the domestic and global flows of minerals and mineral commodity products in the global economy. The NMIC also determines the annual U.S. net import reliance on foreign sources of mineral materials to better understand the Nation's economic and strategic requirements.

Past projects by the NMIC have compiled and mapped the overall structure of the mineral industries across major global regions. These reports, beginning in 2006 with USGS Open-File Report 2006-1375 covering Latin America and Canada and USGS Open-File Report 2006-1135 on Africa and the Middle East, have used data from country profiles within the International Area Reports (Volume III) of the annual U.S. Geological Survey Minerals Yearbook, namely, the locations and ownership of specific mines, processing plants (including refineries and smelters), representative oil and gas field center points, and associated petroleum refineries that are representative of the major production and processing facilities in each country (Bernstein and others, 2006; Eros and Candelario-Quintana, 2006). With the publication in 2010 of the regional reports covering Asia and the Pacific (USGS Open-File Report 2010-1254), Northern and Central Eurasia (USGS Open-File Report 2010-1255), and Europe (USGS Open-File Report 2010-1257), the NMIC completed a comprehensive, near-real-time dataset on the structure of the global mineral industry (Almánzar and others, 2010; Baker and others, 2010a-b). Since 2010, NMIC has continued to modernize its digital geospatial data holdings and processing capabilities, allocating additional resources and leveraging geospatial technologies to deliver a more robust range of data products. Information products derived from updates to the global datasets of mineral facilities, as well as commodityspecific studies on the flows of materials through global supply chains, include the following:

- Four reports on the conflict minerals mined in the Democratic Republic of the Congo, covering gold (George, 2015), tantalum (Papp, 2014), tin (Anderson, 2015), and tungsten (Bermúdez-Lugo, 2014);

- An analysis of the impact of the Ebola virus on the minerals industries of countries of West Africa (Bermúdez-Lugo and Menzie, 2015);

- A 60-year retrospective of U.S. net import reliance for nonfuel mineral commodities (Fortier and others, 2015);

- An overview of the minerals industry of Iran in light of the lifting of economic sanctions in 2016 (Hastorun and others, 2016);

- An analysis of resource nationalism in Indonesia (Lederer, 2016); and

- An overview of global stocks of selected mineral-based commodities (Wilburn and others, 2016).

This report reflects NMIC's ongoing commitment to its mission of understanding the nature and distribution of global mineral commodity supply chains by updating and publishing the georeferenced locations of mineral commodity production and processing facilities in Latin America and the Caribbean. 
This report also incorporates additional geospatial data layers within a file geodatabase to create a new geographic information product in the form of a geospatial portable document format (PDF) map. ${ }^{1}$ This geodatabase and geospatial PDF map include geospatial data on the related physical and economic infrastructure within countries of the region that are required for the extraction and domestic and international trade of mineral resources, as well as additional data layers that highlight exploration and potential areas of future mineral resource extraction and development. Visually comparing the distribution of data across disparate datasets within the multiple data layers of the geospatial PDF map contributes to a deeper understanding of the intersections and complexities of the extractive industries within the region. Some geospatial data layers, such as railroads, electric transmission lines, and oil and gas pipelines, are presented for additional context of the spatial distribution of the related infrastructure of the extractive sector, but this report does not necessarily include detailed attribute information on each related data layer.

\section{Historical background of USGS projects in Latin America and the Caribbean}

The USGS has a long history of collaborative scientific projects with the governments of countries within the Latin America and Caribbean (LAC) region. As an objective and unbiased source for scientific information for the general public, government agencies, and private industry, the USGS conducts scientific research that is not in competition with private or State-sponsored industries within foreign countries. The USGS maintains an Office of International Programs which coordinates cooperative research efforts between the USGS and foreign countries and their scientific and geological counterparts or agencies. The Office of International Programs partners with specific mission areas of the USGS to focus on the following:

- Providing information and technical assistance in response to catastrophic geologic events in foreign countries as well as in reducing risks associated with future catastrophic geologic events (such as earthquakes, landslides, land subsidence, sinkholes, tsunamis, and volcanic eruptions);

- Providing technical assistance in the assessment of energy, mineral, and water resources within foreign countries;

- Developing data and information standards and regional data-sharing networks; and

\footnotetext{
${ }^{1}$ The contributions by non-U.S. Geological Survey (USGS) authors in this compilation, including geospatial data obtained from foreign governmental agencies or non-governmental organizations, are published as they were obtained. Attribute data in original datasets may be more comprehensive in scope than those presented in this compilation. Data produced entirely by non-USGS authors do not necessarily represent the views or position of the USGS or the U.S. Government and are published solely as part of this compilation.
}

- Conducting worldwide scientific assessments of energy and mineral resources.

Examples of collaborative scientific investigations by the USGS with counterpart agencies include studies conducted in Bolivia and Venezuela, in cooperation with the U.S. Trade and Development Program, to produce mineral resource assessments of the Altiplano region in Bolivia (also known as the Bolivian Plateau) and in the Guyana Shield of eastern Venezuela (U.S. Geological Survey and Servicio Geológico de Bolivia, 1992; U.S. Geological Survey and Corporación Venezolana de Guayana, Técnica Minera, C.A., 1993). The Altiplano investigation presented a comprehensive overview of the geologic setting and detail of the area of interest, with geochemical studies, mineral deposit models, geologic analysis of known mineral deposits, and discussions on the application of economic evaluation models to the deposit models (U.S. Geological Survey and Servicio Geológico de Bolivia, 1992, p. vii). The Guyana Shield investigation presented mineral resource assesments of mineral deposits, covering iron, sedimentary manganese, low-sulfide quartz veins, massive sulfide deposits, and dolomite-marble deposits, among others (U.S. Geological Survey and Corporación Venezolana de Guayana, Técnica Minera C.A., 1993, p. v).

Some examples of mineral-related cooperative projects are listed below in table 1. More geological studies and mineral resource assessments conducted in Latin America and the Caribbean may be found through the USGS Publications Warehouse, located at https://pubs.er.usgs.gov/.

\section{Latin America and the Caribbean- Current regional economic context}

The Latin America and Caribbean region includes 33 independent countries and 16 dependencies of foreign governments. Dependencies of the United States-Puerto Rico and the U.S. Virgin Islands - are not included in this report. For some oil and gas data, the Falkland Islands (a British overseas territory that is also known as Islas Malvinas) are included. The Economic Commission for Latin America and the Caribbean (ECLAC) is a part of the United Nations that collects, organizes, and standardizes economic data on the region. Over a 26-year period from 1990 to 2015, ECLAC reported a 111 percent increase in overall annual gross domestic product (GDP) in constant 2015 U.S. dollars for the independent countries ${ }^{2}$ for which it had data, increasing from approximately $\$ 2,700$ trillion in 1990 to $\$ 5,700$ trillion in 2015. The trend is illustrated in figure 1. In 2015, Brazil accounted for the largest percent share of GDP at 41 percent,

\footnotetext{
${ }^{2}$ Antigua and Barbuda, Argentina, The Bahamas, Barbados, Belize, Bolivia, Brazil, Chile, Colombia, Costa Rica, Cuba, Dominica, Dominican Republic, Ecuador, El Salvador, Grenada, Guatemala, Guyana, Haiti, Honduras, Jamaica, Mexico, Nicaragua, Panama, Paraguay, Peru, Saint Kitts and Nevis, Saint Vincent and the Grenadines, Saint Lucia, Suriname, Trinidad and Tobago, Uruguay, and Venezuela.
} 
Table 1. Examples of mineral-related cooperative projects between the U.S. Geological Survey and counterpart agencies in countries of Latin America and the Caribbean.

[NA, not applicable]

\begin{tabular}{|c|c|c|c|c|}
\hline Country & $\begin{array}{l}\text { Commodities } \\
\text { of interest }\end{array}$ & $\begin{array}{c}\text { Country organization/ } \\
\text { agency }\end{array}$ & Program & $\begin{array}{l}\text { Publication } \\
\text { reference }\end{array}$ \\
\hline Bolivia & $\begin{array}{l}\text { Gold, copper, lead, zinc, } \\
\text { silver }\end{array}$ & $\begin{array}{l}\text { Servicio Geológico de } \\
\text { Bolivia }\end{array}$ & $\begin{array}{l}\text { U.S. Trade and Develop- } \\
\text { ment Program and U.S. } \\
\text { Department of State }\end{array}$ & $\begin{array}{l}\text { U.S. Geological Survey } \\
\text { and Servicio Geológico } \\
\text { de Bolivia, } 1992 .\end{array}$ \\
\hline Colombia & Phosphates & $\begin{array}{l}\text { Servicio Geológico } \\
\text { Nacional and the } \\
\text { Inventario Minero } \\
\text { Nacional }\end{array}$ & $\begin{array}{l}\text { USGS program, } \\
\text { sponsored by the U.S. } \\
\text { Agency for Interna- } \\
\text { tional Development } \\
\text { (USAID) and U.S. } \\
\text { Department of State }\end{array}$ & $\begin{array}{l}\text { U.S. Geological Survey } \\
\text { and Servicio Geologico } \\
\text { Nacional de Colombia, } \\
1969 .\end{array}$ \\
\hline Costa Rica & $\begin{array}{l}\text { Gold, copper, lead, zinc, } \\
\text { manganese, chromium, } \\
\text { and bauxite }\end{array}$ & $\begin{array}{l}\text { Dirección General de } \\
\text { Geología, Minas y } \\
\text { Hidrocarburos, and the } \\
\text { Universidad de Costa } \\
\text { Rica }\end{array}$ & $\begin{array}{l}\text { Costa Rican Minerals } \\
\text { Reconnaissance } \\
\text { Program }\end{array}$ & $\begin{array}{l}\text { U.S. Geological Survey, } \\
\text { Dirección General } \\
\text { de Geología, Minas } \\
\text { y Hidrocarburos, and } \\
\text { Universidad de Costa } \\
\text { Rica, } 1987 .\end{array}$ \\
\hline Guyana & Chromium minerals & $\begin{array}{l}\text { Geological Survey of } \\
\text { Guyana }\end{array}$ & NA & $\begin{array}{l}\text { U.S. Geological Survey } \\
\text { and Geological Survey } \\
\text { of Guyana, } 1976 .\end{array}$ \\
\hline Uruguay & Iron and manganese & $\begin{array}{l}\text { Dirección Nacional de } \\
\text { Minería y Geología } \\
\text { (formerly Instituto Geo- } \\
\text { logico del Uruguay) }\end{array}$ & $\begin{array}{l}\text { U.S. Army Mission to } \\
\text { Uruguay under the } \\
\text { auspices of the Govern- } \\
\text { ment of Uruguay and } \\
\text { USAID }\end{array}$ & Wallace, 1976. \\
\hline Venezuela & $\begin{array}{l}\text { Iron, manganese, } \\
\text { polymetallic systems } \\
\text { (copper, lead, zinc, } \\
\text { gold, silver), stone, } \\
\text { uranium-gold }\end{array}$ & $\begin{array}{l}\text { Corporación Venezolana } \\
\text { de Guayana, Técnica } \\
\text { Minera, C.A. }\end{array}$ & NA & $\begin{array}{l}\text { U.S. Geological Survey } \\
\text { and Corporación } \\
\text { Venezolana de } \\
\text { Guayana, Técnica } \\
\text { Minera C.A., } 1993 .\end{array}$ \\
\hline
\end{tabular}

followed by Mexico, Argentina, Colombia, and Chile, at 21 percent, 8 percent, 6 percent, and 5 percent, respectively. The entire Caribbean sub-region accounted for 1 percent of GDP. Mining and mining-related activities accounted for 5 percent of the total GDP in 2015, up from 2 percent in 1990, at 2015 prices (the most recent historical price valuation data available for the mining sector) (Economic Commission for Latin America and the Caribbean, 2017).

Still negatively affected by the global economic downturn that began in 2008-09 and the decline in both fuel and nonfuel mineral commodity prices over intervening years, the region has been impacted by external market forces that have reduced demand for mineral commodities since early 2012, most notably by the reduction in demand from China for copper and iron ore (Seth, 2016). However, some mineral-related activities in the region continued to be robust, with exploration and development of mining for gold accounting for 60 percent of all deposits explored in 2012 (Wacaster and others, 2014). Lack of infrastructure within the region poses a great challenge to future extractive industry development. Willis Towers Watson, a global risk advisory organization, estimated that Latin American countries will need to re-invest 9 percent of GDP toward infrastructure projects until 2020 to remain competitive with other global regions such as Southeast Asia (Campbell, 2013). In 2016, ECLAC reported a decline of 9.1 percent in foreign direct investment within the region, constituting the lowest level since 2010, and closely tied to the natural resource sectors of hydrocarbons and mining (Economic Commission for Latin America and the Caribbean, 2016). 


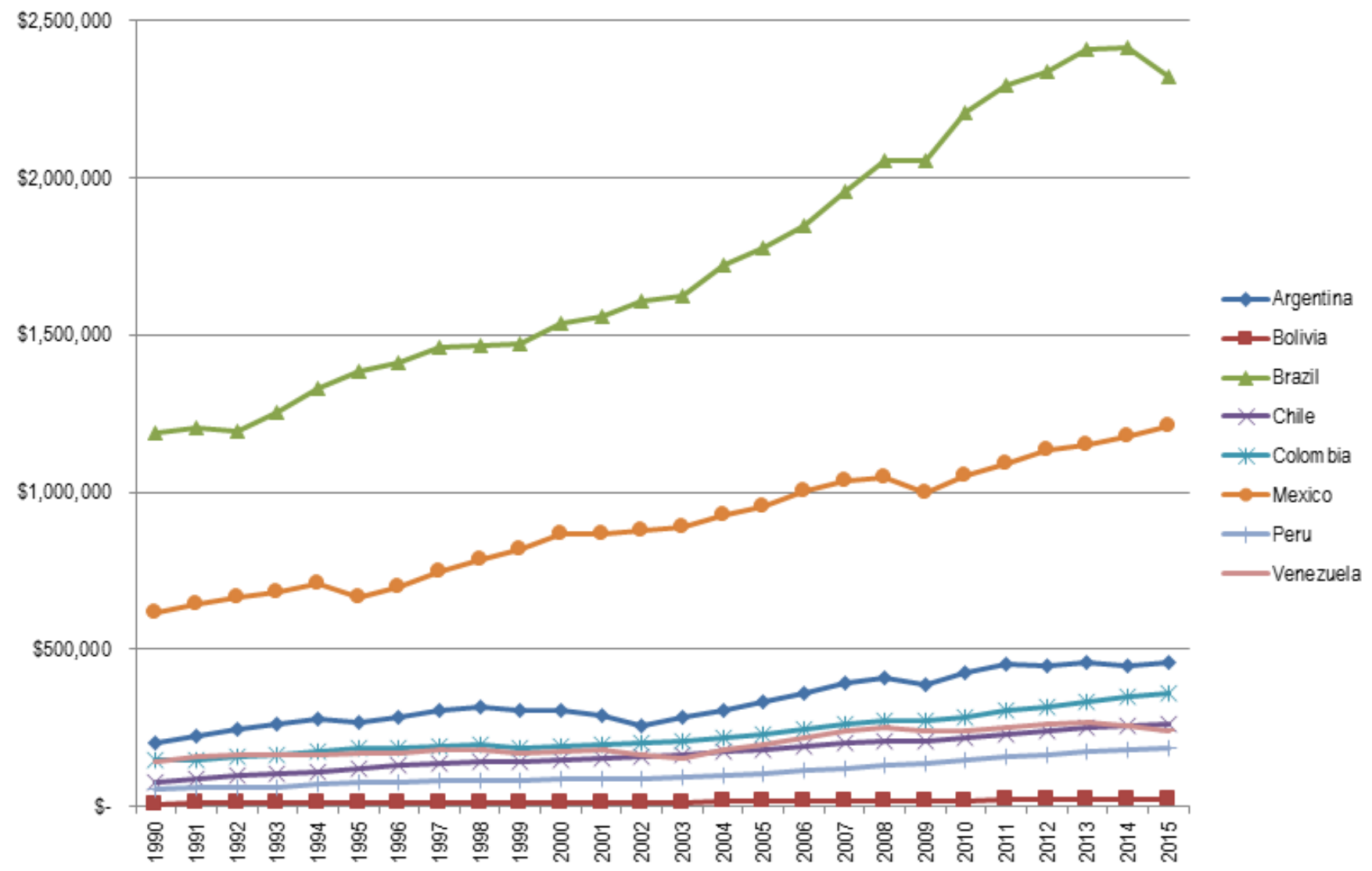

Figure 1. Annual GDP in constant (2015) million U.S. dollars for selected countries in Latin America and the Caribbean, 1990-2015 (Economic Commission for Latin America and the Caribbean (ECLAC), 2017).

\section{Overview of current regional mineral production and reserve estimates}

Major mineral producers of the region include Argentina, Brazil, Bolivia, Chile, Mexico, and Peru, with significant production of metallic mineral resources occurring throughout the American Cordillera from Mexico to Chile. Several of these countries have been among the world's top five leading producers of several nonfuel mineral commodities since the late 2000s by both mine production tonnage and value: Brazil for kaolin, niobium-columbium, tantalum, and iron ore, as well as accounting for a third of the global supply of bauxite; Chile for copper, iodine, lithium, and rhenium, in addition to being a major producer of boron and molybdenum; Bolivia for antimony; Mexico for barite, bismuth, fluorspar, gypsum, silver, strontium, and wollastonite; and Peru for copper, gold, lead, silver, tin, and zinc. Colombia is a major producer of coal whereas Mexico and Venezuela produce globally significant amounts of crude petroleum.
Table 2 shows the total percentage of global production per mineral commodity for several of the region's largest producers (Anderson, 2016a-d; Bedinger, 2016; Bray, 2016a-b; Brininstool, 2016; Corathers, 2016; Crangle, 2016; Gambogi, 2016; George, 2016a-b; Guberman, 2016b; Jasinski, 2016a-b; Jaskula, 2016; Kuck, 2016; McRae, 2016a-b; Olson, 2016; Papp, 2016a-b; Polyak, 2016a-b; Schnebele, 2016; Shedd, 2016; Tolcin, 2016; Tuck, 2016).

Based on reserve estimates for 2015, the LAC region contains globally significant reserves for niobium (columbium), lithium, and rhenium, at 95 percent (Brazil), 54 percent (Chile), and 52 percent (Chile) of the global reserves, respectively. Brazil contains 36 percent and 31 percent, respectively, of the global reserves of tantalum and graphite, while Chile contains 29 percent and 21 percent, respectively, of the global reserves of copper and selenium. Peru contains 21 percent and 13 percent of the global reserves of silver and zinc, respectively. Table 3 highlights the countries in the region that rank among the top three countries globally for containing 
Table 2. Globally significant nonfuel mineral commodity-producing countries in Latin America and the Caribbean, showing mineral commodity, 2015 preliminary production estimate by country, 2015 preliminary global production, and country production as percent share of global production.

[Data from individual chapters of the USGS's Mineral Commodity Summaries, 2016. Production type is annual mine production for all mineral commodities except molybdenum, the production type of which is unknown. Units are thousand metric tons of metal content or industrial mineral, except where otherwise noted]

\begin{tabular}{|c|c|c|c|c|}
\hline Country & Commodity & $\begin{array}{l}\text { Country preliminary } \\
2015 \text { production } \\
\text { (thousand metric tons) }\end{array}$ & $\begin{array}{l}\text { Global preliminary } \\
2015 \text { production } \\
\text { (thousand metric tons) }\end{array}$ & $\begin{array}{l}\text { Country percent } \\
\text { of global production }\end{array}$ \\
\hline Brazil & Niobium (Columbium) & 50 & 56 & 89 \\
\hline Chile & Iodine & 20 & 30.3 & 66 \\
\hline Chile & Rhenium & $\begin{array}{l}26,000 \text { kilograms of } \\
\text { rhenium content }\end{array}$ & $\begin{array}{l}46,000 \text { kilograms of } \\
\text { rhenium content }\end{array}$ & 57 \\
\hline Chile & Copper & 5,700 & 18,700 & 31 \\
\hline Mexico & Silver & 5.4 & 27.3 & 20 \\
\hline Chile & Molybdenum & 49 & 267 & 18 \\
\hline Mexico & Fluorspar & 1,110 & 6,250 & 18 \\
\hline Peru & Silver & 3.8 & 27.3 & 14 \\
\hline Brazil & Tantalum & $\begin{array}{l}150 \text { metric tons of } \\
\text { tantalum content }\end{array}$ & $\begin{array}{l}1,200 \text { metric tons of } \\
\text { tantalum content }\end{array}$ & 13 \\
\hline Peru & Zinc & 1,370 & 13,400 & 10 \\
\hline Chile & Boron & 580 & 5,960 & 10 \\
\hline Peru & Copper & 1,600 & 18,700 & 9 \\
\hline Argentina & Boron & 500 & 5,960 & 8 \\
\hline Peru & Tin & 22.5 & 294 & 8 \\
\hline Bolivia & Tin & 20 & 294 & 8 \\
\hline Peru & Molybdenum & 18.1 & 267 & 7 \\
\hline
\end{tabular}

mineral reserves of nonfuel mineral commodities as of 2015 (Anderson, 2016a-d; Bedinger, 2016; Bray, 2016a-b; Brininstool, 2016; Corathers, 2016; Crangle, 2016; Gambogi, 2016; George, 2016a-b; Guberman, 2016a; Jasinski, 2016a-b; Jaskula, 2016; Kuck, 2016; McRae, 2016a-b; Olson, 2016; Papp, 2016a-b; Polyak, 2016a-b; Schnebele, 2016; Shedd, 2016; Tolcin, 2016; Tuck, 2016).

Table $1-1$ in appendix 1 includes complete 2015 reserve estimates as well as 2014 annual production and 2015 preliminary production estimates for LAC countries included in the USGS's 2016 Mineral Commodity Summaries, including those commodities with significant global reserves that do not rank in the top three among mineral commodity. Note: the reserves and production data from the Mineral Commodity Summaries are not within the geodatabase or visualized in the geospatial PDF map, but are provided in appendix 1 of this report for reference.

\section{Overview of the file geodatabase- LAC_Indust_Infra.gdb}

\section{Geodatabase structure and overview of geospatial PDF map}

\section{Overview of the file geodatabase- LAC_Indust_Infra.gdb}

The primary goal of this project was to compile a range of geospatial data layers that contribute to the analysis of the extractive fuel and nonfuel mineral industries and the related economic and physical infrastructure that are integral for the successful operation of the mineral industries 
Table 3. Countries ranking among the top three globally per nonfuel mineral commodity reserve estimate in Latin America and the Caribbean for 2015 , by global rank and alphabetically by mineral commodity and country.

[Data are from the USGS's Mineral Commodity Summaries, 2016. Units are million metric tons of metal content or industrial mineral, unless otherwise specified. >, greater than; kg, kilogram]

\begin{tabular}{|c|c|c|c|c|c|}
\hline Country & $\begin{array}{l}\text { Mineral } \\
\text { commodity }\end{array}$ & $\begin{array}{c}2015 \text { country } \\
\text { reserve estimate } \\
\text { (million metric tons) }\end{array}$ & Global rank & $\begin{array}{c}2015 \text { global } \\
\text { reserve estimate } \\
\text { (million metric tons) }\end{array}$ & $\begin{array}{c}\text { Country percent } \\
\text { of global reserve } \\
\text { estimate }\end{array}$ \\
\hline Chile & Copper & 210 & 1 & 720 & 29 \\
\hline Chile & Lithium & $\begin{array}{l}7,500 \text { metric tons of } \\
\text { lithium content }\end{array}$ & 1 & $\begin{array}{l}14,000 \text { metric tons of } \\
\text { lithium content }\end{array}$ & 54 \\
\hline Brazil & $\begin{array}{l}\text { Niobium (colum- } \\
\text { bium) }\end{array}$ & 4.1 & 1 & $>4.3$ & 95 \\
\hline Chile & Rhenium & $\begin{array}{l}1,300,000 \mathrm{~kg} \text { of } \\
\text { rhenium content }\end{array}$ & 1 & $\begin{array}{l}2,500,000 \mathrm{~kg} \text { of } \\
\text { rhenium content }\end{array}$ & 52 \\
\hline Peru & Silver & $\begin{array}{l}120,000 \text { metric tons } \\
\text { of silver content }\end{array}$ & 1 & $\begin{array}{c}570,000 \text { metric tons } \\
\text { of silver content }\end{array}$ & 21 \\
\hline Peru & Tellurium & $\begin{array}{l}3,600 \text { metric tons of } \\
\text { tellurium content }\end{array}$ & 1 & $\begin{array}{l}25,000 \text { metric tons of } \\
\text { tellurium content }\end{array}$ & 14 \\
\hline Chile & Iodine & 1.8 & 2 & 75 & 24 \\
\hline Brazil & Nickel & 10 & 2 & 79 & 13 \\
\hline Brazil & Rare earths & $\begin{array}{l}22 \text { (rare-earth oxide } \\
\text { (REO) equivalent) }\end{array}$ & 2 & 130 & 17 \\
\hline Chile & Selenium & $\begin{array}{l}25,000 \text { metric tons of } \\
\text { selenium content }\end{array}$ & 2 & $\begin{array}{l}120,000 \text { metric tons } \\
\text { of selenium content }\end{array}$ & 21 \\
\hline Brazil & Tantalum & $\begin{array}{l}36,000 \text { metric tons of } \\
\text { tantalum content }\end{array}$ & 2 & $\begin{array}{c}>100,000 \text { metric tons } \\
\text { of tantalum content }\end{array}$ & 36 \\
\hline Bolivia & Antimony & 0.31 & 3 & 2 & 16 \\
\hline Brazil & Bauxite & 2.6 (dry) & 3 & 28 & 9.3 \\
\hline Peru & Zinc & 25 & 3 & 200 & 13 \\
\hline
\end{tabular}

within the region and the transporation of mineral products across domestic and global markets. An Esri ${ }^{3}$ ArcGIS file geodatabase, LAC_Indust_Infra.gdb, was constructed to allow for centralized data management of the geospatial data layers. Additional sections of this report go into further detail discussing the individual data layers (also called feature classes), their methodologies and data sources, as well as their broader analytical context. Comprehensive metadata are available for this geodatabase which, in addition to this report, explain any user-defined attribute data contained with any

${ }^{3}$ Esri is a software development and services company providing geographic information systems software and geodatabase management applications. data tables, including any coded values or abbreviations used within data tables.

The geodatabase (LAC_Indust_Infra.gdb) is a single Esri file geodatabase that includes seven feature datasets, which contain more than 20 data feature classes that are shown within the geospatial PDF map. New point data feature classes were researched, compiled, and published as separate USGS data releases: mines and mineral processing plant facilities (also referred to as "mineral facilities" broadly), mineral exploration and development sites, and mineral commodity exporting ports (Baker, Bleiwas, and Goonan, 2016; Baker and Buteyn, 2016; Baker and Wilburn, 2016). Additional point data feature classes compiled from other sources 
include locations of liquefied natural gas terminals, porphyry copper deposits, and oil and gas field center points. Polyline data feature class examples include oil and gas pipelines, transmission lines, and oil and gas concession leasing areas. Polygon data feature class examples include USGS petroleum provinces and porphyry copper tracts potentially containing polymetallic deposits. A down-sampled 30-meter (m) regional digital elevation model (DEM) is included for generalized topographic reference. This file geodatabase along with its metadata and a map document file in the compressed archive file LAC_Indust_Infra.zip are available at https:// doi.org/10.3133/ofr20171079. Figure 2 and table 4 show the structure of the file geodatabase, as organized by the seven top-level feature datasets, as well as a top-level raster feature.

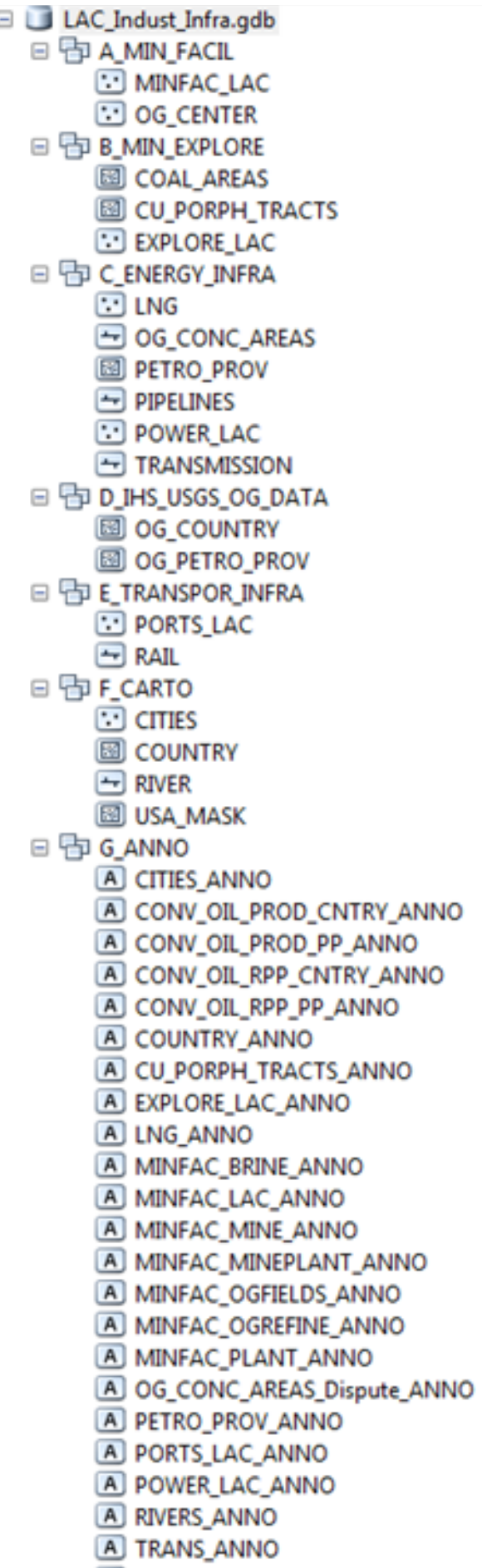

Figure 2. File structure for $L A C \_I n d u s t$ Infra.gdb geodatabase.
A RIVERS_ANNO
A TRANS_ANNO
A XMark_City
A XMark_CoalAreas
A XMark_Country
A XMark_CuPorph
A XMark_Explore
A XMark_LNG
A XMark_MinFac_Brine
A XMark_MinFac_Mine
A XMark_MinFac_MinePlant
A XMark_MinFac_OGField
A XMark_MinFac_OGRefinery
A XMark_MinFac_Plant
A XMark_OGCENTER
A XMark_OGConcAreas
A XMark_PetroProv
A XMark_Pipelines
A XMark_Ports
A XMark_Power
A XMark_ProdCntry_OilProd
A XMark_ProdPP_OilProd
A XMark_Railroads
A XMark_Rivers
A XMark_RPP_PP_OilProd
A XMark_RPPCntry_OilProd
A XMark_Topo
A XMark_TransLines
門 LAC_ELEVATION 
Table 4. Description of feature datasets within the file geodatabase LAC_Indust_Infra.gdb and supporting metadata files, as well as the related data folder name within the geospatial PDF map.

[NA, not applicable]

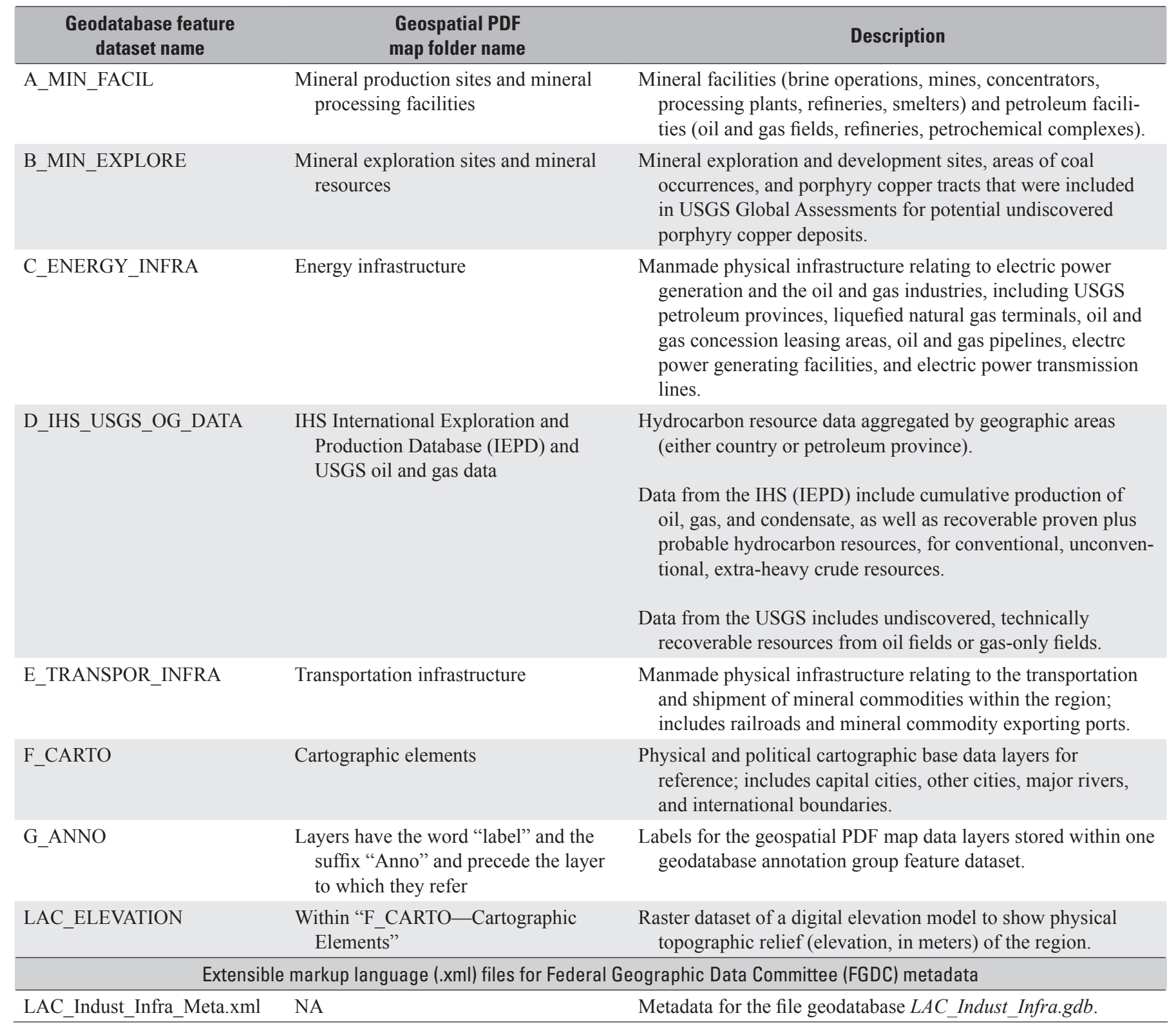

\section{Overview of geospatial PDF map layout (layer navigation and visibility)}

The geospatial PDF map created for this project contains the feature datasets and their feature classes organized as map layers. Within a PDF reader, such as Adobe Reader, these layers are accessed through a layer navigation pane on the lefthand side of the screen when the PDF file is open (figure 3). For this geospatial PDF map, there is one layer navigation menu for the "LAC Regional Map" layer.
Figure 4 shows a list of the feature dataset folders containing the feature classes, or individual data layers, within the geospatial PDF map. Clicking the "plus" button next to a folder will expand the folder so the folder contents are visible, as in figure 5. Clicking on the eye icon to the left of any individual feature class data layer within a folder turns on or off the visibility of that individual data layer; clicking on the eye icon next to the top-level feature dataset folder turns off visibility of all contents within that folder. If all feature datasets and classes are turned on simulatenously, the map 


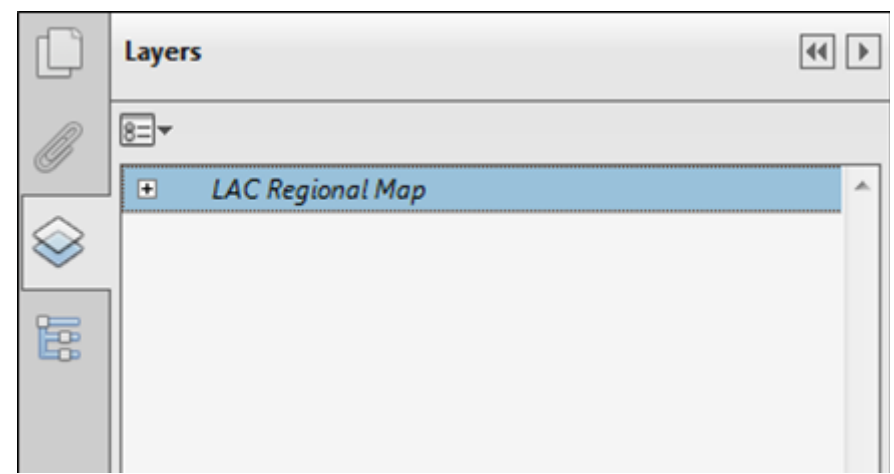

Figure 3. Screenshot of the geospatial PDF map, showing the left-hand layer navigation pane open.

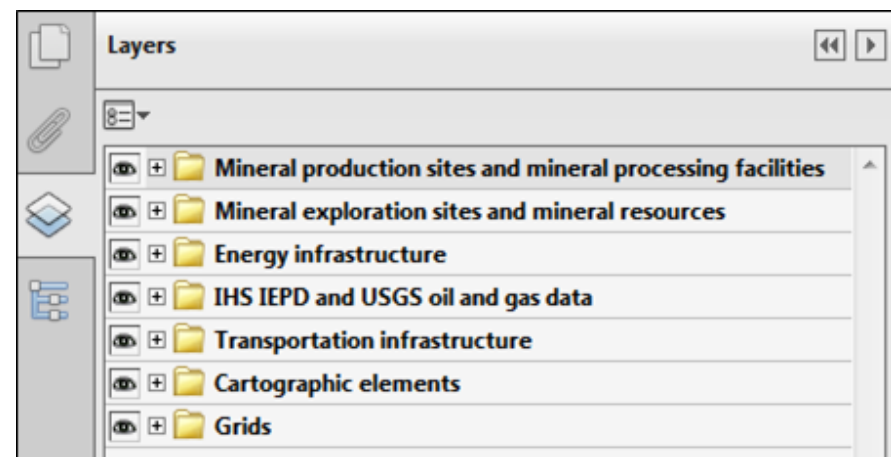

Figure 4. List of feature dataset folders within the geospatial PDF map.

will be illegible due to the number of data layers present and overlapping labels. However, a user may selectively turn on or off different layers and their labels to analyze the spatial relationships between the feature classes. Base cartographic elements that are visible upon opening the geospatial PDF map, such as vector data points for cities, vector polyline data for major rivers or international boundaries, and raster digital elevation model (DEM) data for the topographic relief, can be turned off for clearer visual interpretation of data feature classes. Turning off topographic relief may enhance visual analysis, by showing only the international boundaries.

Attribute data cannot be accessed through this navigation pane. See the following section for information on accessing attribute data with the map. Annotation group layers for labels directly precede the layer they refer to and can be turned on and off separately for better visual clarity between other data layers. A user is able to generate different maps of individual data layers by controlling the visibility of data layers and their labels, which can then be printed out as an individual map. For example, a user could overlay oil and gas field center points with the USGS petroleum provinces to determine which cluster of oil and gas fields is within which specific petroleum province; the user will then have the ability to print out that specific representation.

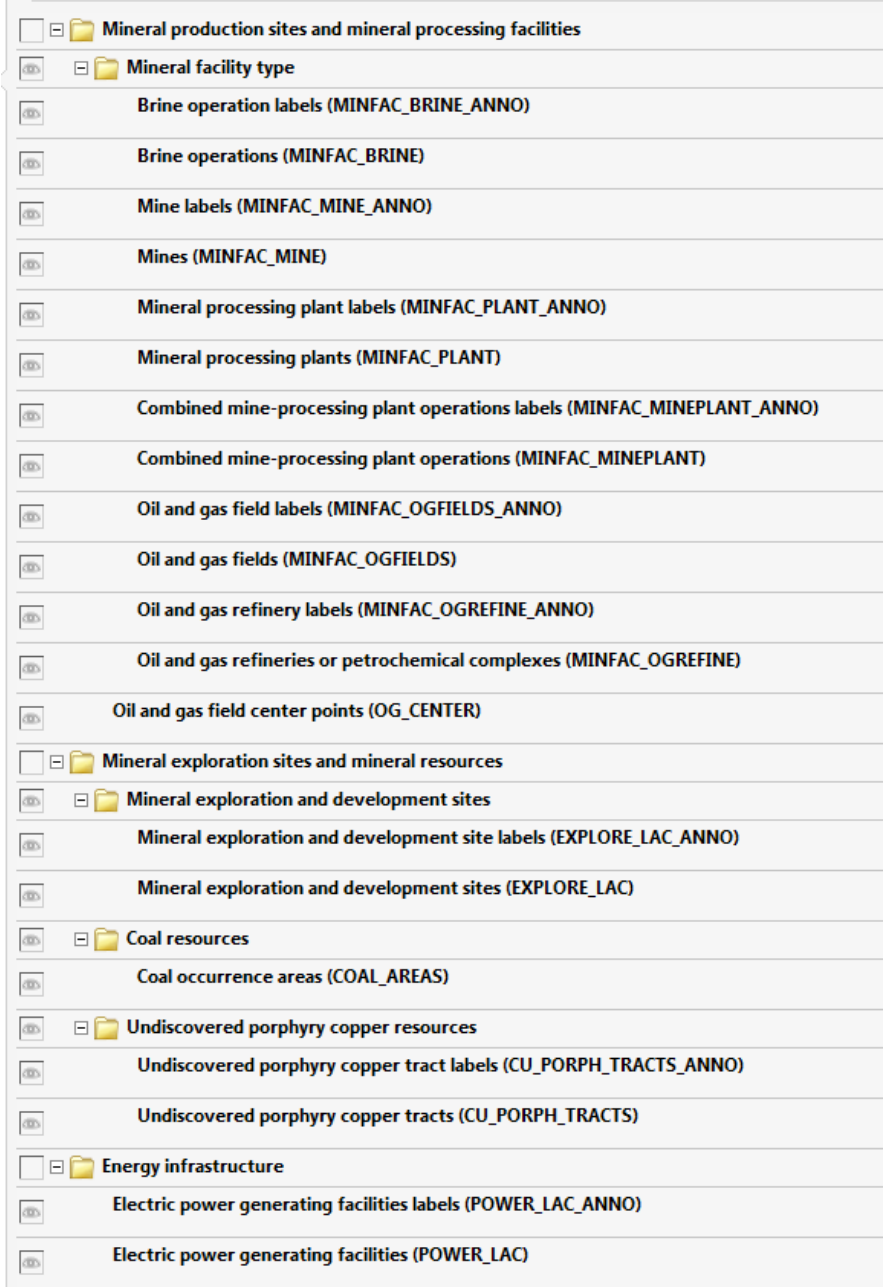

Figure 5. Expanded feature dataset folders showing individual data feature classes, or data layers, associated annotation group layers, or label layers, and the visibility controls within Adobe Reader. Values in parentheses indicate the corresponding feature class in the geodatabase. 


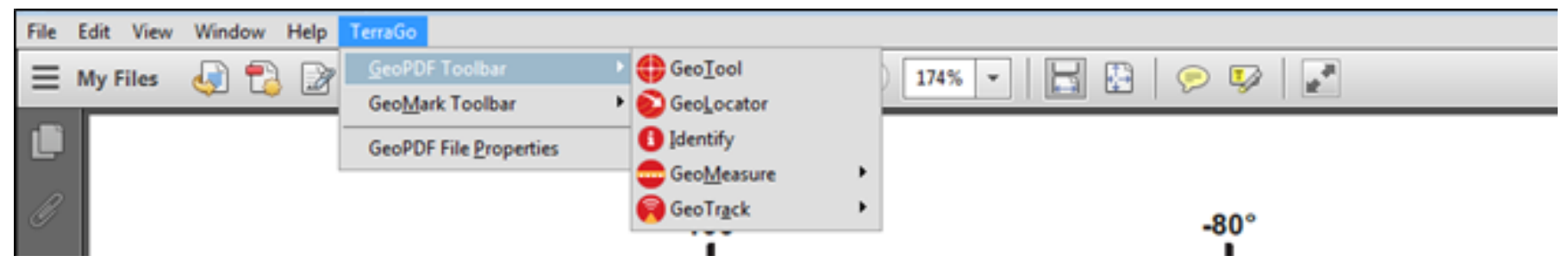

Figure 6. Screenshot of TerraGo Toolbar installed on a computer as a top menu, within Adobe Reader, showing several geospatial tools available for use.

\section{Using the "Identify" and "Search" toolbars to access data feature class attribute data}

The geospatial map produced as part of this report is a TerraGo Technologies geospatial PDF map (GeoPDF). The proprietary software that creates this type of a geospatial PDF map allows several of the core functions of the map to work, namely, the ability to export multiple geospatial data layers into a geopackage that supports data queries while the PDF is open in Adobe Reader, as well as advanced file size compression algorithms. A geopackage is a "hidden" SQLite database embedded into the geospatial PDF map. The benefits of this functionality include the ability to generate PDF maps that contain attribute data within the PDF so a user does not have to cross-reference against external data sources. For maximized usage of this map, users may download the latest version of the TerraGo Toolbar, a free plug-in for Adobe Reader and Adobe products, available at http://www. terragotech.com/products/terrago-toolbar. ${ }^{4}$

Upon installation, the TerraGo Toolbar appears as a top menu within Adobe Reader (fig. 6) or as an Extended menu on the right-hand side of the Adobe Reader screen (fig. 7). Both toolbar locations offer the same functionality to the user.

${ }^{4}$ Any use of trade, firm, or product names, including TerraGo Technologies, TerraGo Toolbar, and TerraGo GeoPDF is for descriptive purposes only, to better inform the user of advanced functions presented by this technology, and does not imply endorsement by the U.S. Government.

\section{Using the "Identify" tool}

Figure 7 shows the location of the "Identify" tool. This tool enables a user to click on a drawn feature of a feature class, such as a point or polygon, which contains attribute data. Within the "Identify" window a user can see the attribute data associated with that feature. Table 5 shows which geodatabase feature classes and map layers have attribute data within the geospatial PDF map. See specific report sections for those map layers having attributes for which data attribute fields are included. In table 5, the column labelled "additional detailed attribute information included in geodatabase data tables" refers to additional tabular data, beyond geospatial geometry parameters, that may be included, but which are not included in the attribute fields within the map (owing to limitations on total file size for the PDF; excessive attribute data can render the PDF unuseable). Attribute data are packaged into an Open Geospatial-Consortium-compliant Geopackage within the geospatial PDF map; a GeoPackage is a SQLite database that can retain multiple vector features and attributes with efficient drawing capabilities. SQLite is a database engine that allows a SQL-type database to be embedded within a product. Owing to the large amount of attribute information for the mineral facilities within the region, when a user clicks on the "Identify" tool, it may take a while to load, or "hang," especially once the file is first opened; this is normal software behavior.
Figure 7. Screenshot of TerraGo Toolbar installed on a computer as an Extended menu on the righthand side, within Adobe Reader, showing several geospatial tools available for use.

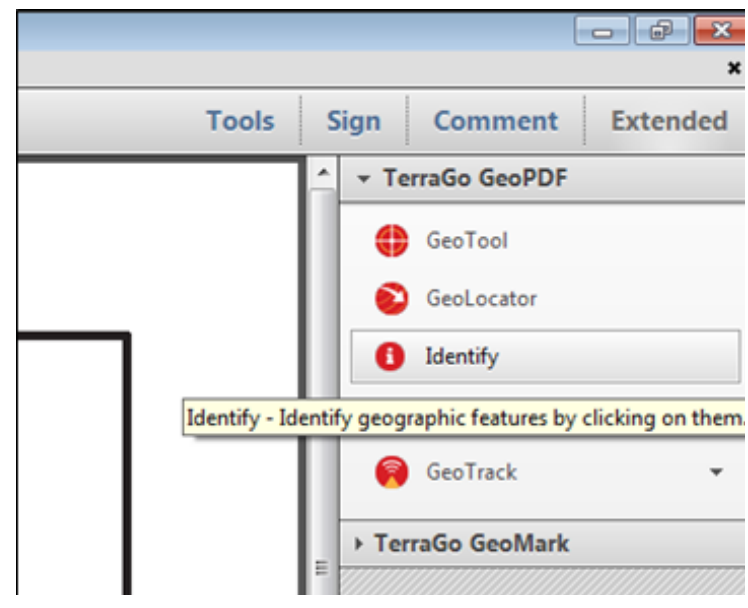


Table 5. Geodatabase feature classes, geospatial PDF map data layers, and included attributes in the geospatial PDF map.

[RPP, recoverable proven plus probable resources; NA, not applicable]

\begin{tabular}{|c|c|c|c|c|}
\hline $\begin{array}{l}\text { Geodatabase feature } \\
\text { class name }\end{array}$ & $\begin{array}{l}\text { Geospatial PDF map and } \\
\text { ArcGIS map document } \\
\text { (.mxd) data layer name }\end{array}$ & $\begin{array}{l}\text { Attribute information } \\
\text { included in geo- } \\
\text { spatial PDF map }\end{array}$ & $\begin{array}{l}\text { User-defined attribute field } \\
\text { used as map layer label in } \\
\text { geospatial PDF map }\end{array}$ & $\begin{array}{l}\text { Additional detailed attribute } \\
\text { information included in } \\
\text { geodatabase data tables }\end{array}$ \\
\hline \multicolumn{5}{|c|}{ Feature dataset A_MIN_FACIL - Mineral production sites and mineral processing facilities } \\
\hline \multirow[t]{7}{*}{ MINFAC_LAC } & $\begin{array}{l}\text { Mineral facilities, which } \\
\text { include the following } \\
\text { separate data layers for } \\
\text { better display: }\end{array}$ & Yes & "FACID" & Yes \\
\hline & Brine operations & & & \\
\hline & Mines & & & \\
\hline & Mineral processing plants & & & \\
\hline & $\begin{array}{l}\text { Combined mine-plant } \\
\text { operations }\end{array}$ & & & \\
\hline & Oil and gas fields & & & \\
\hline & $\begin{array}{l}\text { Oil and gas refineries } \\
\text { and (or) petrochemical } \\
\text { complexes }\end{array}$ & & & \\
\hline OG_CENTER & $\begin{array}{l}\text { Oil and gas field center } \\
\text { points }\end{array}$ & No & Not labeled & No \\
\hline \multicolumn{5}{|c|}{ Feature dataset B_MIN_EXPLORE - Mineral exploration sites and mineral resources } \\
\hline COAL_AREAS & Coal occurrence areas & No & Not labeled & Yes \\
\hline CU_PORPH_TRACTS & $\begin{array}{l}\text { Undiscovered porphyry } \\
\text { copper tracts }\end{array}$ & No & $\begin{array}{l}\text { "Tract_name" and } \\
\text { "TractID" fields } \\
\text { combined. }\end{array}$ & Yes \\
\hline & & & $\begin{array}{l}\text { For example, the Sonoran } \\
\text { Desert tract has the } \\
\text { TractID MX-J2 and is } \\
\text { labeled as "Sonoran } \\
\text { Desert (MX-J2)." }\end{array}$ & \\
\hline EXPLORE_LAC & $\begin{array}{l}\text { Mineral exploration and } \\
\text { development sites }\end{array}$ & Yes & "FACID" & Yes \\
\hline \multicolumn{5}{|c|}{ Feature dataset C_ENERGY_INFRA - Energy infrastructure } \\
\hline LNG & $\begin{array}{l}\text { Liquefied natural gas } \\
\text { terminals }\end{array}$ & Yes & "Project_Name" & Yes \\
\hline OG_CONC_AREAS & $\begin{array}{l}\text { Oil and gas concession } \\
\text { leasing areas }\end{array}$ & No & Not labeled & No \\
\hline PETRO_PROV & USGS petroleum provinces & No & "NAME" & Yes \\
\hline PIPELINES & Oil and gas pipelines & No & Not labeled & No \\
\hline POWER_LAC & $\begin{array}{l}\text { Electric power generating } \\
\text { facilities }\end{array}$ & Yes & "FACID" & Yes \\
\hline TRANSMISSION & $\begin{array}{l}\text { Electric power transmission } \\
\text { lines }\end{array}$ & No & Not labeled & No \\
\hline \multicolumn{5}{|c|}{ Feature dataset D_IHS_USGS_OG_DATA - IHS IEPD and USGS oil and gas data } \\
\hline OG_COUNTRY & $\begin{array}{l}\text { Cumulative conventional oil } \\
\text { production, by country }\end{array}$ & Yes & "RANK1" & Yes \\
\hline OG_PETRO_PROV & $\begin{array}{l}\text { Cumulative conventional oil } \\
\text { production, by petroleum } \\
\text { province }\end{array}$ & Yes & "RANK1" & Yes \\
\hline
\end{tabular}


Table 5. Geodatabase feature classes, geospatial PDF map data layers, and included attributes in the geospatial PDF map.—Continued [RPP, recoverable proven plus probable resources; NA, not applicable]

\begin{tabular}{|c|c|c|c|c|}
\hline $\begin{array}{l}\text { Geodatabase feature } \\
\text { class name }\end{array}$ & $\begin{array}{l}\text { Geospatial PDF map and } \\
\text { ArcGIS map document } \\
\text { (.mxd) data layer name }\end{array}$ & $\begin{array}{l}\text { Attribute information } \\
\text { included in geo- } \\
\text { spatial PDF map }\end{array}$ & $\begin{array}{l}\text { User-defined attribute field } \\
\text { used as map layer label in } \\
\text { geospatial PDF map }\end{array}$ & $\begin{array}{l}\text { Additional detailed attribute } \\
\text { information included in } \\
\text { geodatabase data tables }\end{array}$ \\
\hline OG_COUNTRY & $\begin{array}{l}\text { Conventional oil, RPP, by } \\
\text { country }\end{array}$ & Yes & "RANK2" & Yes \\
\hline OG_PETRO_PROV & $\begin{array}{l}\text { Conventional oil, RPP, by } \\
\text { petroleum province }\end{array}$ & Yes & "RANK2" & Yes \\
\hline \multicolumn{5}{|c|}{ Feature dataset E_TRANSPOR_INFRA - Transportation infrastructure } \\
\hline PORTS_LAC & $\begin{array}{l}\text { Mineral commodity } \\
\text { exporting ports }\end{array}$ & Yes & "PORTNAME" & Yes \\
\hline RAIL & Railroads & No & Not labeled & No \\
\hline \multicolumn{5}{|c|}{ Feature dataset F_CARTO - Cartographic elements } \\
\hline CITIES & Capital and other cities & No & "NAME" & Yes \\
\hline COUNTRY & International boundaries & No & "NAME" & No \\
\hline RIVERS & Major rivers & No & "NAME" & No \\
\hline USA & United States & $\begin{array}{l}\text { Not in project study } \\
\text { area; grayed out } \\
\text { and shown for } \\
\text { reference }\end{array}$ & Not labeled & No \\
\hline LAC_ELEVATION & Topographic relief & No & Not labeled & NA \\
\hline \multicolumn{5}{|c|}{ Feature dataset G_ANNO - Annotation group } \\
\hline
\end{tabular}

48 annotation group label layers as individual feature class (not listed here).

Two categories are included: (i) annotation group label layers for data layers and (ii) annotation group layer using an " $X$ " to indicate which layer is visible in the geospatial PDF map in the upper right-hand corner of the map.

In the map document table of contents and geospatial PDF map, label layers precede the data layer to which they refer and have the word "label" in the layer title. In the geodatabase, these layers are indicated with the suffix "ANNO."

In the map document table of contents, the visibility indicator layers have the prefix "XMark_" and precede the data layer to which they refer. In the geodatabase, these layers follow the same format, with the prefix "XMark_." In the geospatial PDF map, these "XMark_" layers are not visible at all and are instead part of the data layer itself.

The "Identify" feature works best at 100 percent zoom level for the entire document. One software limitation to this tool is that increasing the document zoom level to 200 percent or higher causes the crosshair target to have a more difficult time selecting the feature. Point features should be clicked nearest to the center of the symbol icon on the map document. If multiple feature classes are shown at the same time, it may be necessary to turn off any other feature classes to avoid inadvertently selecting a different feature. There is no option to select all objects within a polygon search area by dragging the cursor over drawn symbols. On older computers, or for users working with an older version of Adobe Reader, the "Identify" feature may hang or load slowly between different feature selections, or may not be functional. Table 6 shows which feature class attribute fields are included in the geospatial PDF map for general reference. See additional sections of this report for a detailed discussion of each of these attribute fields and their values. 
Table 6. List of attribute fields included in the geospatial PDF map, by data feature class.

\begin{tabular}{lc}
\hline \multicolumn{1}{c}{ Geodatabase feature class name } & Attribute fields included in the geospatial PDF map \\
\hline MINFAC_LAC & FACID, COUNTRY, COMMODITY, MIN_PROD, LOCDESC, LOCNAME, FACTYPE, \\
& OPERATOR, ANNCAP, UNITS, COMBOCAP, STATUS, LOCACC \\
\hline POWER_LAC & FACID, COUNTRY, PLANTNAME, CAPACITY_MW, ENERGY_TYPE \\
\hline LNG & FACID, COUNTRY, PROJECT_NAME, LOCATION_DESCRIPTION, TYPE, OWNERS \\
PORTS_LAC & FACID, PORTPRODID, MULTI_REC, COUNTRY, PORTNAME, COMM_EXPD, \\
& FORM_COMM, EST_ANN_TONNAGE, DEST, FEED_SOURCE \\
EXPLORE_LAC & FACID, COUNTRY, PROJTYPE, PROJNAME, COMM \\
OG_COUNTRY & COUNTRY, CONV_OILFLD \\
& For cumulative production of conventional oil: CONV_OILCM_MCM, CAT 1, RANK 1 \\
& For recoverable proven plus probable conventional oil resources: CONV_OILRPP_MCM, CAT 2, \\
& RANK 2 \\
USGS_PP_CODE, USGS_PP_NAME, CONV_OILFLD \\
For cumulative production of conventional oil: CONV_OILCM_MCM, CAT 1, RANK 1 \\
For recoverable proven plus probable conventional oil resources: CONV_OILRPP_MCM, CAT 2, \\
RANK 2 \\
\hline
\end{tabular}

\section{Using the "Search" function within the "Identify" tool}

Within the "Identify" tool window, a search bar is located immediately at the top (figure 8). This search bar allows for character string-based searches within relevant feature classes. A character string refers to any combination of text or numeric characters that could be a stand-alone defined word or only a portion of a word. Similarly to the potential for lag-time on loading the "Identify" tool, the "Search" function may pause when performing queries that return multiple results; for example; a search for "gold" returns 233 results across the "MINFAC_LAC," "EXPLORE_LAC," and "PORTS_LAC" feature classes.

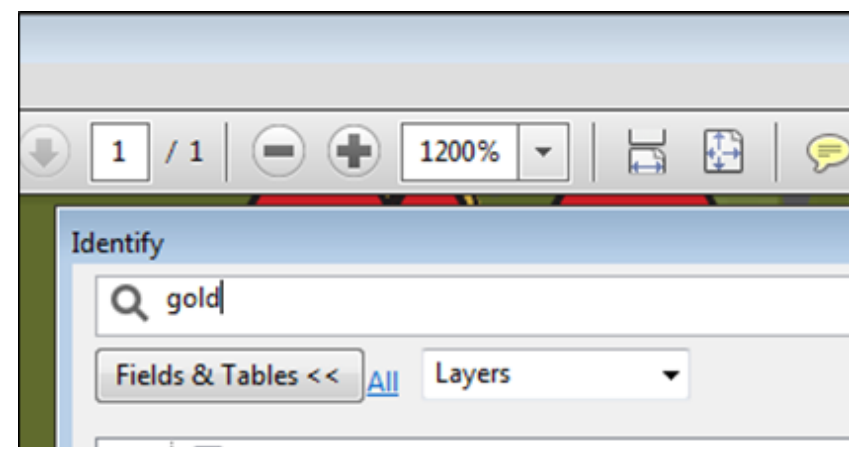

Figure 8. Screenshot of the "Identify" window, showing the "Search" function.
The visibility of a data layer is irrelevant to the "Search" function, meaning that data layers that are turned off are also searchable, depending on the input string. The "Search" parameters are inclusive; for example, a string of "tin" would return mineral facility records that have the string "tin" anywhere in any data field, including both mineral commodity records for the element tin and records of the country of Argentina.

Figure 9 shows an example of the results of the "Search" function with the mineral commodity exporting ports feature class, labelled as "Ports" in the map document. A user can click through the results list to see the attribute information per data record.

The software is limited to exact string inputs. So for example, searching for "gold, Bolivia," will not return all gold records within Bolivia. In this case, the program will be searching for anything that exactly matches "gold, Bolivia," which in the context of this project, is an unlilely combination of search terms. Users will have better results with broad and simple searches for specific locations, such as a city or port name, or for a specific mineral commodity ("lithium") or form of a mineral commodity ("lithium hydroxide"). This software plug-in does not have the full functionality of more robust database querying capabilities, including multiple string searches. Figure 10 shows when search results are returned from multiple data layers; a user has the option to scroll through multiple results and expand or collapse coverage from multiple layers. 


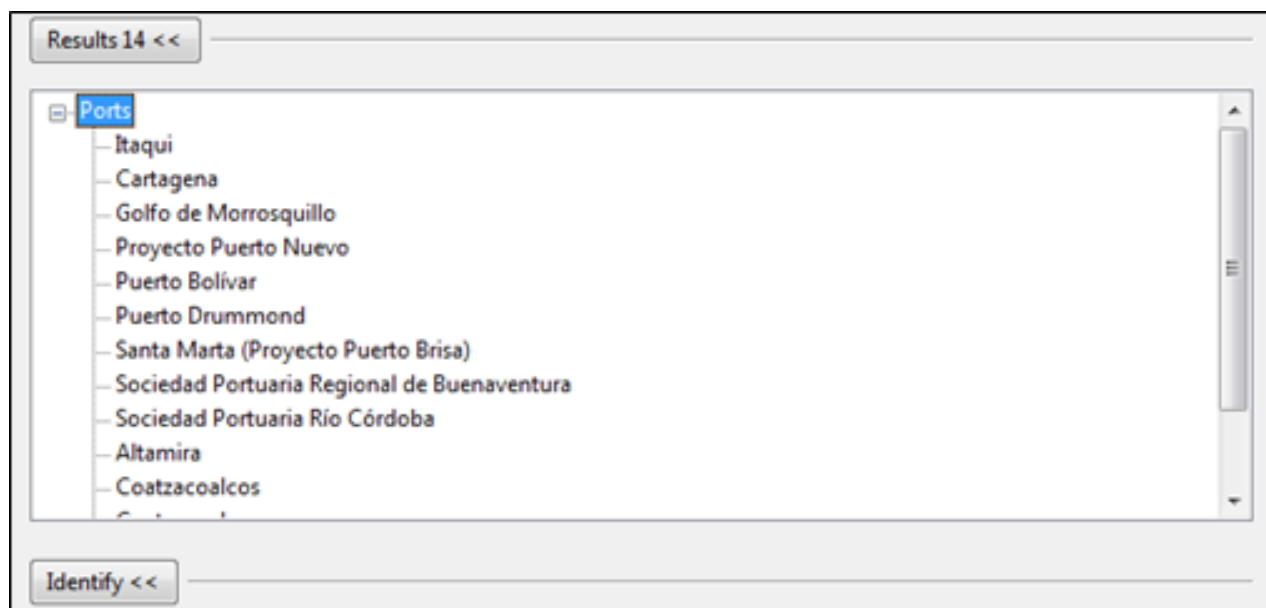

Figure 9. Example results after performing a search with the "Search" function within the "Identify" window.

Figure 10. Expanded results of a search with the string "coal." The Fields \& Tables tab shows data layers containing a result. The Results tab shows individual data points containing a match with the search query string; the number following the word "Results," 78, indicates the total number of matches. The Identify tab shows individual field values for a data point when that data point is selected in the Results tab. Note that the selection in this example is for a port name (highlighted in yellow) that contains the string "coal" and is not a mineral commodity entry; the software returns any entries that match the text string searched.

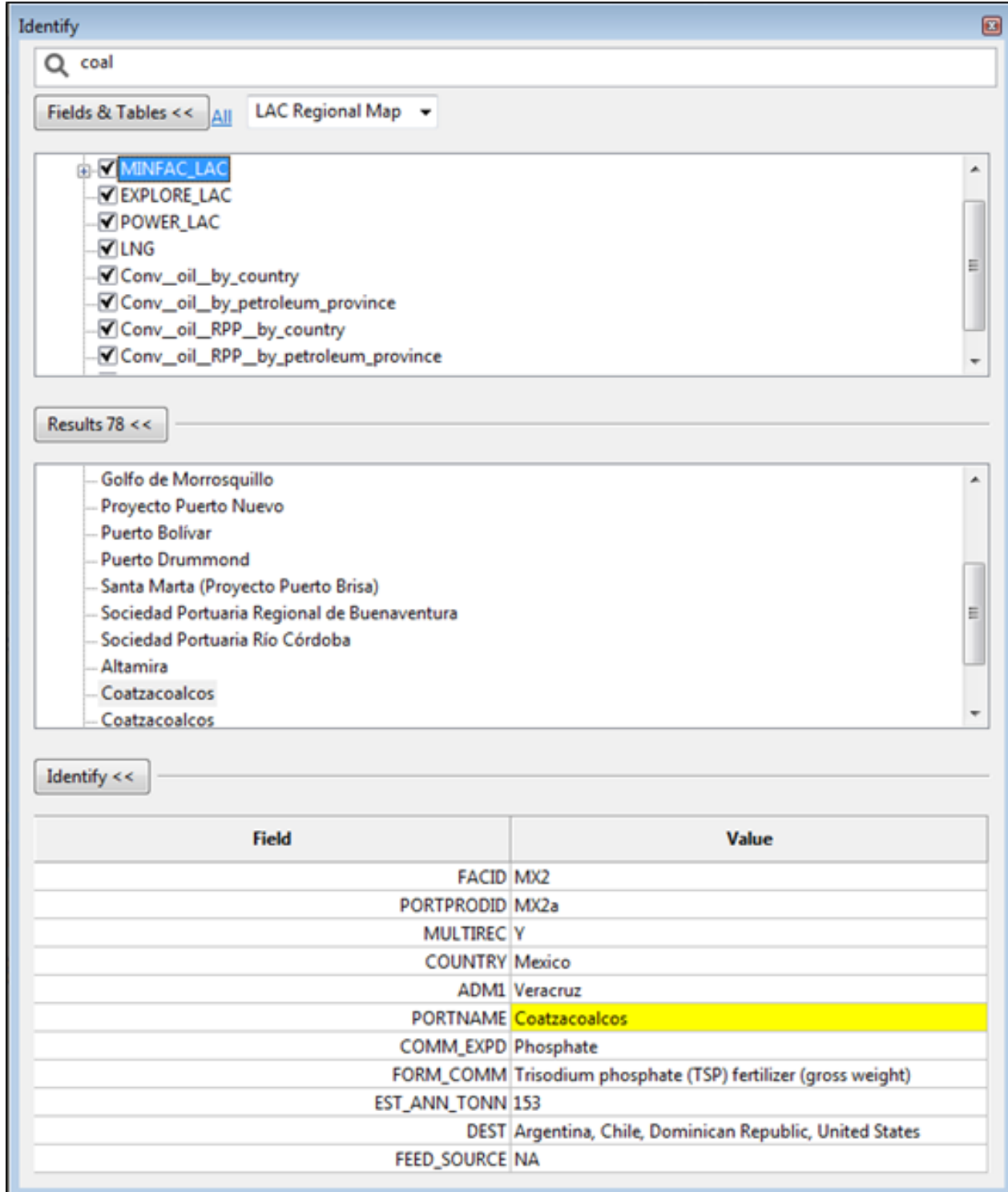




\section{Overview of geospatial data layers}

\section{Mineral production sites and mineral processing facilities-A_MIN_FACIL feature dataset}

The feature dataset $A \_M I N \_F A C I L$ contains vector point data covering the mines, mineral processing facilities, oil and gas fields, petroleum refineries, metal refineries and smelters, and similar production and extraction-related geospatial data. Table 7 shows the individual feature classes within this feature dataset.

\section{Mineral facilities: mines and processing facilities-MINFAC_LAC feature class}

Central to NMIC's mission in understanding global mineral commodity supply chains is the compilation and publication of tables highlighting the structure of the global mineral industry in Volume III of the annual U.S. Geological Survey Minerals Yearbook (https://minerals.usgs.gov/ minerals/pubs/country/). This volume is organized by major geographic regions, of which Latin America and Caribbean, along with Canada, are combined as one. Country specialists within NMIC's Global Minerals Analysis Section assemble data into a table which includes the following:

- Mineral commodity and specific forms of mineral commodity products (if known).

- Major operating companies and major equity owners.

- Names and locations of mines and mineral processing facilities.

- Annual capacity per facility for that given mineral commodity or specific form of mineral commodity product. $^{5}$

${ }^{5} \mathrm{NMIC}$ tracks the annual production capacities of international facilities as opposed to the annual production figure. Data are published to reflect the overall structure of a country's mineral industry from year to year, rather than the specific annual production at individual facilities. Table 1 of each individual country chapter within Volume III presents an overview of annual production within a specific country.
Locations $s^{6}$ of facilities are determined from company reports and websites, atlases of mining locations from foreign countries' governments and universities, and a variety of geological and scientific literature and data resources. These tables are not necessarily comprehensive or exhaustive for any one country but generally do contain the major mineral-related facilities within most countries. For example, information and data on the nature and extent of some industrial mineral operations can be difficult to obtain and fully validate; therefore, this data layer may be more heavily skewed toward metals. It is also important to note that oil and gas fields and petroleum-producing areas within this data layer include only those for which NMIC country specialists were able to determine annual capacities; additional oil and gas field center points from other USGS sources are shown in a separate data layer for general spatial reference but do not contain attribute information (see next section). ${ }^{7}$

Table 8 shows the attribute fields contained in the mineral facility data feature class MINFAC_LAC, the range of specific field values if applicable, and necessary comments for interpretation of the data. The full mineral facility data feature class, as well as metadata explaining all attribute field values, codes, and abbreviations, is available as a USGS data release (Baker and Buteyn, 2016) through the USGS ScienceBase data release page, available at https://doi.org/10.5066/ F7MG7MM6.

In the geospatial PDF map, the six categories of facility types are shown as separate map layers for better understanding of the geographic distribution of the varying kinds of facilities and for improved legibility of the map labels. Labels are shown as separate data layers that have the title format of "MINFAC_[Facility Type]_ANNO," indicating that they belong to the MINFAC data feature class and are

\footnotetext{
${ }^{6}$ Throughout this report and geodatabase, all locations contain information on the locational accuracy of individual points. "A" represents approximate locations; "E" represents exact locations. Approximate locations may be present owing to several factors, including (1) the nature of the input data point is more suited to a single approximate point, as in the case of aggregated information at a country level, (2) available satellite imagery was too low in resolution for the exact identification of a facility, or (3) conflicting information existed in public sources as to the exact location.

${ }^{7}$ Not all information contained within Volume III of the Minerals Yearbook may be included within the MINFAC_LAC feature class, owing to revisions or delayed release of updated country information.
}

Table 7. Data feature classes within the $A \_M I N \_F A C I L$ feature dataset of the file geodatabase $L A C \_I n d u s t \_I n f r a . g d b$.

\begin{tabular}{lll}
\hline \multicolumn{1}{c}{ Feature class name } & Feature class name in geospatial PDF map & \multicolumn{1}{c}{ Description } \\
\hline MINFAC_LAC & Mineral facility types & $\begin{array}{c}\text { Vector point data. Fuel and nonfuel mineral facilities each a } \\
\text { separate map layer: brine, mine, mineral processing plant, mine } \\
\text { and plant combined, oil and gas field, oil and gas refinery and } \\
\text { (or) petrochemical complex. }\end{array}$ \\
\hline OG_CENTER & Oil and gas field center points & $\begin{array}{c}\text { Vector point data. Oil and gas field center points derived from the } \\
\text { USGS Energy Resources Program publication. Included for } \\
\text { visual spatial reference; no attribute data are included in the } \\
\text { geodatabase. }\end{array}$ \\
\hline
\end{tabular}


Table 8. Description of user-defined attribute fields in the mines and mineral processing facilities feature class MINFAC_LAC.

[ID, identification; e.g., for example; GENC, Geopolitical Entities, Names, and Codes]

\begin{tabular}{|c|c|c|c|c|c|}
\hline $\begin{array}{c}\text { Data release and } \\
\text { geodatabase field } \\
\text { name }\end{array}$ & Field alias & Field type & Description & $\begin{array}{l}\text { Examples of values } \\
\text { (if applicable) }\end{array}$ & $\begin{array}{l}\text { Attribute field } \\
\text { included in geo- } \\
\text { spatial PDF map }\end{array}$ \\
\hline OBJECTID & Object ID & Numeric (integer) & $\begin{array}{l}\text { Unique ID number for each data } \\
\text { record object }\end{array}$ & Sequential order, ascending & No \\
\hline ROWID & Row ID & Numeric (integer) & $\begin{array}{l}\text { Unique ID number for each row } \\
\text { from original dataset }\end{array}$ & Sequential order, ascending & No \\
\hline GENC_CC & GENC country code & Text & GENC two-digit country code & Unique to each country & No \\
\hline FACID_NUM & Facility ID number & Numeric (integer) & $\begin{array}{l}\text { Unique ID number per facility } \\
\text { per country }\end{array}$ & Sequential order, ascending, restarts for each country. & No \\
\hline FACID & Facility ID & Alphanumeric & $\begin{array}{l}\text { GENC_CC combined with } \\
\text { FACID_NUM. } \\
\text { Used as labels on map. }\end{array}$ & Sequential order, ascending & Yes \\
\hline MULTI_COMM & Multiple commodities & Text & $\begin{array}{l}\text { Multiple commodities produced } \\
\text { at a single facility }\end{array}$ & $\begin{array}{l}\text { Flagged "Y" to indicate when multiple commodities } \\
\text { are produced at a single facility. } \\
\text { Example 1: Aguilar Mine in Argentina produces lead } \\
\text { and silver concentrates. } \\
\text { Example 2: The Vinto smelting complex in Bolivia } \\
\text { produces antimony, bismuth, lead, silver, tin, and } \\
\text { tin-lead alloys. }\end{array}$ & No \\
\hline MULTI_PROD & Multiple products & Text & $\begin{array}{l}\text { Multiple products of at least one } \\
\text { mineral commodity produced } \\
\text { at a single facility }\end{array}$ & $\begin{array}{l}\text { Flagged "Y" to indicate when multiple products of } \\
\text { at least one mineral commodity are produced at a } \\
\text { single facility. } \\
\text { Example 1: The ArcelorMittal steel mill at the Point } \\
\text { Lisas Industrial Estate in Trinidad and Tobago } \\
\text { produces steel billets, direct-reduced iron pellets, } \\
\text { and steel wire rods, all examples of iron and steel } \\
\text { products. } \\
\text { "Iron and steel" is treated as a single commodity, } \\
\text { separate from iron ore, iron and steel scrap, or iron } \\
\text { and steel slag. }\end{array}$ & No \\
\hline COUNTRY & Country & Text & Country name & Country name & Yes \\
\hline
\end{tabular}


Table 8. Description of user-defined attribute fields in the mines and mineral processing facilities feature class MINFAC_LAC._CContinued

[ID, identification; e.g., for example; GENC, Geopolitical Entities, Names, and Codes]

\begin{tabular}{|c|c|c|c|c|c|}
\hline $\begin{array}{c}\text { Data release and } \\
\text { geodatabase field } \\
\text { name }\end{array}$ & Field alias & Field type & Description & $\begin{array}{l}\text { Examples of values } \\
\text { (if applicable) }\end{array}$ & $\begin{array}{l}\text { Attribute field } \\
\text { included in geo- } \\
\text { spatial PDF map }\end{array}$ \\
\hline YEAR & Year & Numeric & $\begin{array}{l}\text { Year of data source material in } \\
\text { Volume III of the Minerals } \\
\text { Yearbook. Ninety-five percent } \\
\text { of records are from } 2014 .\end{array}$ & 2013,2014 , or 2015 & No \\
\hline COMMTYPE & Mineral commodity type & Text & Mineral commodity type & $\begin{array}{l}\text { Three mineral commodity types: fuel, industrial, } \\
\quad \text { and metal. } \\
\text { Fuel examples: } \\
\text { Coal } \\
\text { Methanol } \\
\text { Natural gas } \\
\text { Petroleum } \\
\text { Industrial examples: } \\
\text { Cement } \\
\text { Clays } \\
\text { Phosphate } \\
\text { Metal examples: } \\
\text { Gold } \\
\text { Silver } \\
\text { Lead } \\
\text { Zinc } \\
\text { Copper }\end{array}$ & No \\
\hline COMMODITY & Mineral commodity & Text & Mineral commodity & USGS mineral commodity names & Yes \\
\hline MIN_PROD & $\begin{array}{l}\text { Form of mineral } \\
\text { commodity product }\end{array}$ & Text & $\begin{array}{l}\text { Specific form of a mineral } \\
\text { commodity produced at a } \\
\text { given facility }\end{array}$ & $\begin{array}{l}\text { Variable depending on mineral commodity. } \\
\text { Examples include: } \\
\text { Ore } \\
\text { Ores and concentrates } \\
\text { Concentrates } \\
\text { Refined (e.g., metal) } \\
\text { Refinery products } \\
\text { Crude (e.g., petroleum) } \\
\text { Note: when unknown or unspecified, this field may } \\
\quad \text { simply be a duplicate of the COMMODITY field. }\end{array}$ & Yes \\
\hline
\end{tabular}


Table 8. Description of user-defined attribute fields in the mines and mineral processing facilities feature class MINFAC_LAC.—Continued

[ID, identification; e.g., for example; GENC, Geopolitical Entities, Names, and Codes]

\begin{tabular}{|c|c|c|c|c|c|}
\hline $\begin{array}{l}\text { Data release and } \\
\text { geodatabase field } \\
\text { name }\end{array}$ & Field alias & Field type & Description & $\begin{array}{l}\text { Examples of values } \\
\text { (if applicable) }\end{array}$ & $\begin{array}{l}\text { Attribute field } \\
\text { included in geo- } \\
\text { spatial PDF map }\end{array}$ \\
\hline ADM1 & $\begin{array}{l}\text { First-order administrative } \\
\text { division }\end{array}$ & Text & $\begin{array}{l}\text { First-order administrative } \\
\text { divisions are the equivalents } \\
\text { of States in Brazil, Mexico, } \\
\text { and the United States }\end{array}$ & $\begin{array}{l}\text { Codeset from National Geospatial-Intelligence } \\
\text { Agency }\end{array}$ & No \\
\hline LOCDESC & Location description & Text & $\begin{array}{l}\text { The full description of the loca- } \\
\text { tion as given in the chapter of } \\
\text { Volume III of the Minerals } \\
\text { Yearbook } \\
\text { Included to show how many } \\
\text { specific locations may share } \\
\text { an annual } \\
\text { capacity when capacities are } \\
\text { given for multiple locations }\end{array}$ & Variable text & Yes \\
\hline LOCNAME & Location name & Text & $\begin{array}{l}\text { Condensed version of location } \\
\text { description, limited to specific } \\
\text { mine or mineral processing } \\
\text { plant name, if available or } \\
\text { applicable }\end{array}$ & $\begin{array}{l}\text { Variable. May just be a general statement (e.g., } \\
\text { "Buenos Aires plant"). }\end{array}$ & Yes \\
\hline FACTYPE & Facility type & Text & $\begin{array}{l}\text { Type of facility, corresponding to } \\
\text { symbology on map }\end{array}$ & $\begin{array}{l}\text { - B - Brine operation } \\
\cdot \mathrm{M}-\text { Mine } \\
\cdot \mathrm{M} / \mathrm{P}-\mathrm{Co}-\text { located mine and plant } \\
\cdot \mathrm{P}-\text { Mineral processing plant (processor of concen- } \\
\text { trate or refinery / smelter; post-concentrator) } \\
\text { - OG - Oil and gas field } \\
\text { - OR - Oil and gas refinery and (or) petrochemical } \\
\quad \text { complex }\end{array}$ & Yes \\
\hline OPERATOR & Operating company & Text & $\begin{array}{l}\text { Operator information from } \\
\text { source material in Volume III } \\
\text { of the Minerals Yearbook }\end{array}$ & $\begin{array}{l}\text { First given value in the combined "Operator and } \\
\text { ownership" column of individual country chapters } \\
\text { within Volume III of the Minerals Yearbook. }\end{array}$ & Yes \\
\hline OWNER & Ownership & Text & $\begin{array}{l}\text { Ownership information from in } \\
\text { Volume III of the Minerals } \\
\text { Yearbook }\end{array}$ & $\begin{array}{l}\text { Second given values in the combined "Operator and } \\
\text { ownership" column of individual country chapters } \\
\text { within Volume III of the Minerals Yearbook. }\end{array}$ & No \\
\hline
\end{tabular}


Table 8. Description of user-defined attribute fields in the mines and mineral processing facilities feature class MINFAC_LAC_-Continued

[ID, identification; e.g., for example; GENC, Geopolitical Entities, Names, and Codes]

\begin{tabular}{|c|c|c|c|c|c|}
\hline $\begin{array}{c}\text { Data release and } \\
\text { geodatabase field } \\
\text { name }\end{array}$ & Field alias & Field type & Description & $\begin{array}{l}\text { Examples of values } \\
\text { (if applicable) }\end{array}$ & $\begin{array}{l}\text { Attribute field } \\
\text { included in geo- } \\
\text { spatial PDF map }\end{array}$ \\
\hline ANNCAP & $\begin{array}{l}\text { Annual production } \\
\text { capacity }\end{array}$ & Numeric & $\begin{array}{l}\text { As listed in source material in } \\
\text { Volume III of the Minerals } \\
\text { Yearbook }\end{array}$ & $\begin{array}{l}\text { Capacities may repeat several times due to geograph- } \\
\text { ically distinct facilities having a combined annual } \\
\text { capacity. Care should be taken when adding } \\
\text { capacities for the same mineral commodity within } \\
\text { a country (see below with the "COMBOCAP" } \\
\text { field description). } \\
\text { These data may not be comprehensive for a given } \\
\text { country. }\end{array}$ & Yes \\
\hline ECAP & $\begin{array}{l}\text { Estimated annual } \\
\text { capacity }\end{array}$ & Text & $\begin{array}{l}\text { Estimated annual production } \\
\text { capacity }\end{array}$ & Flagged "e" if estimated. & No \\
\hline UNITS & $\begin{array}{l}\text { Units of measure for annual } \\
\text { production capacity }\end{array}$ & Text & $\begin{array}{l}\text { Units of measure for annual } \\
\text { production capacity }\end{array}$ & $\begin{array}{l}\cdot \mathrm{mt}-\text { metric tons } \\
\cdot \mathrm{tmt} \text { - thousand metric tons } \\
\cdot \mathrm{kg} \text { - kilograms } \\
\cdot \mathrm{NA} \text { - not available / not applicable } \\
\cdot \mathrm{mcm}-\text { million cubic meters } \\
\text { - } \mathrm{tcmpd} \text { - thousand cubic meters per day } \\
\text { - } \mathrm{t} 42 \text {-gb - thousand 42-gallon barrels } \\
\cdot \mathrm{t} 42 \text {-gbpd - thousand 42-gallon barrels per day } \\
\cdot \mathrm{m} 42 \text {-gb - million 42-gallon barrels }\end{array}$ & Yes \\
\hline COMBOCAP & Combined capacities & Text & $\begin{array}{l}\text { Some entries from original } \\
\text { source material have multiple } \\
\text { locations that share one given } \\
\text { annual capacity figure. } \\
\text { To track individual locations and } \\
\text { retain the capacity informa- } \\
\text { tion, this field acts as a flag } \\
\text { to users so that they will not } \\
\text { assume that the given capacity } \\
\text { is for that one particular loca- } \\
\text { tion only and instead is shared } \\
\text { across multiple locations } \\
\text { under the same ownership. }\end{array}$ & $\begin{array}{l}\text { “***\#-\#” notation with FACID numbers } \\
\text { (FACID_NUM) listed. } \\
\text { For example, an entry flagged in this field as } \\
\text { "***5-8” would indicate that the given annual } \\
\text { production capacity is a combined figure for data } \\
\text { records with the FACID_NUM's of 5, 6, 7, and } 8 \text {. } \\
\text { These entries should all have the same ownership } \\
\text { information, but commonly include geographi- } \\
\text { cally distinct facilities. }\end{array}$ & Yes \\
\hline
\end{tabular}


Table 8. Description of user-defined attribute fields in the mines and mineral processing facilities feature class MINFAC_LAC._Continued

[ID, identification; e.g., for example; GENC, Geopolitical Entities, Names, and Codes]

\begin{tabular}{|c|c|c|c|c|c|}
\hline $\begin{array}{c}\text { Data release and } \\
\text { geodatabase field } \\
\text { name }\end{array}$ & Field alias & Field type & Description & $\begin{array}{l}\text { Examples of values } \\
\text { (if applicable) }\end{array}$ & $\begin{array}{l}\text { Attribute field } \\
\text { included in geo- } \\
\text { spatial PDF map }\end{array}$ \\
\hline STATUS & Operating status & Text & $\begin{array}{l}\text { Assumed active for a given year } \\
\text { if not annotated in source } \\
\text { material. }\end{array}$ & $\begin{array}{l}\text { - A - active } \\
\text { - } \mathrm{C} \text { - closed / past producer } \\
\text { - } \mathrm{CM} \text { - care and maintenance } \\
\text { - } \mathrm{S} \text { - suspended } \\
\text { - } \mathrm{U} \text { - unknown } \\
\text { - UC - under construction } \\
\text { - UD - under development }\end{array}$ & Yes \\
\hline LOCACC & Locational accuracy & Text & $\begin{array}{l}\text { Accuracy of the given coordi- } \\
\text { nates for the facility }\end{array}$ & $\begin{array}{l}\text {-A - Approximate location } \\
\text { - E - Exact location }\end{array}$ & Yes \\
\hline DDLAT & Latitude in decimal degrees & Numeric & Latitude in decimal degrees & Variable & No \\
\hline DDLONG & Longitude in decimal degrees & Numeric & Longitude in decimal degrees & Variable & No \\
\hline SOURCEID & Source / reference ID & Text & Source index number & $\begin{array}{l}\text { Internal USGS reference to georeferencing sources } \\
\text { Sources for this data field refer to the references used } \\
\text { to determine geographic location. } \\
\text { The actual source material for the data record is } \\
\text { Volume III of the Minerals Yearbook. }\end{array}$ & No \\
\hline COMMENTS & Comments & Text & Comments and explanatory notes & If included in source material & No \\
\hline
\end{tabular}


the annotation group containing the labels. The facility type appears in the middle of the text string; for example, "MINFAC_BRINE_ANNO" is the label annotation group for the brine operations map layer in the PDF.

For this report, the six facility type categories are defined as follows:

\section{Brine operations}

- Facilities extracting or processing brine-based mineral solutions in the liquid form.

2. Mines

- Operations producing either metallic mineral ores or mineral concentrates (including concentration mills / beneficiation plants that are not also producing refined metals or downstream products), including from surface mines and underground mines. Also including quarries producing industrial minerals.

\section{Mineral processing plants}

- For metallic minerals, operations that consume mineral concentrates for processing downstream refined metallic products; for industrial minerals, such as cement plants, operations that process raw material into a finished industrial product.

\section{Combined mine and processing plants}

- Where indicated in Volume III of the Minerals Yearbook, these facilities are co-located mining and processing operations, often with any ore or mineral concentrates produced or milled onsite also being processed into further downstream products at the adjacent processing plant. Within the geodatabase, these values are derived from the "LOCDESC," or location description field.

\section{Oil and gas fields}

- Oil and natural gas fields. Some individual data records may refer to a specific oil and gas field with an individual annual capacity for that field, whereas other data records may refer to an aggregated annual capacity number for one company across several fields in a wide geographic area, commonly at the first-order administrative level division.

\section{Oil and gas refineries and (or) petrochemical complexes}

- Oil and gas refineries and (or) petrochemical complexes that are processing crude oil or natural gas into downstream petrochemical products.

The mineral facility data feature class contains more than 1,300 total records relating to the extractive mineral industries of Latin America and the Caribbean. More than 1,100 unique facilities are contained within this data feature class. Of the 33 independent countries and 16 dependencies of foreign governments within the LAC region, the MINFAC_LAC data feature class contains information on the mining and mineral processing facilities of 27 independent countries ${ }^{8}$ and two foreign dependencies [Aruba (the Netherlands) and French Guiana (France)]. Independent countries and foreign dependencies that are not included in this feature class are those islands of the Caribbean which do not support any mining or mineral-related activity, or for which no available data were found.

Table 9 shows the distribution of data records by country. The top four countries on the basis of number of total records - Chile, Bolivia, Brazil, and Peru — account for approximately 66 percent of the total number of records, and are among the region's largest producers of mineral commodities. However, other countries may have locally important mines and mineral processing facilities, which significantly contribute to those countries' overall economies. As described in table 8 for the "MULTI_COMM" and "MULTI_PROD" fields, there is not a one-to-one relationship between the number of data records and the number of facilities. Facilities can be listed multiple times owing to multiple commodities being produced onsite (such as different metallic elements contained within ore and concentrated into separate mineral commodity products at a mine) or because different product forms of the same mineral commodity are produced onsite (such as a variety of steel products all being produced at a mill, each with a different annual production capacity listed in the table). Caution should be exercised when summing or aggregating information on annual production capacities. Multiple geopgrahically disparate facilities may share a single capacity if that is the lowest level of data resolution that was found by the original researchers of the individual chapters of Volume III of the Minerals Yearbook. These facilities are flagged by the field "COMBOCAP," which stands for combined capacity, and have the individual facility identification numbers included in the data point of the "COMBOCAP" field.

By commodity type, metals accounted for 668 total records, or 50 percent, followed by industrial minerals with 433 , or 33 percent, and fuel minerals with 231 , or 17 percent. Based on geographic research to determine the location of facilities, 1,195 records, or 90 percent, have exact locational accuracy, with the other 137 records, or 10 percent, having approximate locations. Active facilities account for 1,149 records, or 86 percent, for the given calendar year of the source material. Twenty-two records, or 2 percent, were suspended, while all other operational statuses (under construction, under development, on care-and-maintenance, unknown, or closed) account for the remaining 12 percent of the total record count.

\footnotetext{
${ }^{8}$ The independent countries are Argentina, The Bahamas, Barbados, Belize, Bolivia, Brazil, Chile, Colombia, Costa Rica, Cuba, Dominican Republic, Ecuador, El Salvador, Guatemala, Guyana, Haiti, Honduras, Jamaica, Mexico, Nicaragua, Panama, Paraguay, Peru, Suriname, Trinidad and Tobago, Uruguay, and Venezuela. All of these countries except Cuba are borrowing members of the Inter-American Development Bank.
} 
Table 9. Total count of mineral facility data records in the MINFAC_LAC data feature class, by country.

[Percent totals are rounded to no more than two significant figures; may not add to totals shown]

\begin{tabular}{|c|c|c|}
\hline Country & $\begin{array}{l}\text { Total number of } \\
\text { records per country }\end{array}$ & $\begin{array}{l}\text { Percent of total } \\
\text { for record count }\end{array}$ \\
\hline Argentina & 77 & 6 \\
\hline Aruba & 1 & 0 \\
\hline Bahamas, The & 1 & 0 \\
\hline Barbados & 1 & 0 \\
\hline Belize & 2 & 0 \\
\hline Bolivia & 132 & 10 \\
\hline Brazil & 241 & 18 \\
\hline Chile & 372 & 28 \\
\hline Colombia & 45 & 3 \\
\hline Costa Rica & 8 & 1 \\
\hline Cuba & 28 & 2 \\
\hline Dominican Republic & 7 & 1 \\
\hline Ecuador & 21 & 2 \\
\hline El Salvador & 6 & 0 \\
\hline French Guiana & 3 & 0 \\
\hline Guatemala & 29 & 2 \\
\hline Guyana & 4 & 0 \\
\hline Honduras & 6 & 0 \\
\hline Jamaica & 10 & 1 \\
\hline Mexico & 79 & 6 \\
\hline Nicaragua & 7 & 1 \\
\hline Panama & 1 & 0 \\
\hline Paraguay & 5 & 0 \\
\hline Peru & 133 & 10 \\
\hline Suriname & 15 & 1 \\
\hline Trinidad And Tobago & 39 & 3 \\
\hline Uruguay & 7 & 1 \\
\hline Venezuela & 52 & 4 \\
\hline Total & 1,332 & \\
\hline
\end{tabular}

The top 20 mineral commodities by total number of records within this dataset all have at least 12 records each across all countries and represent 1,073 total data records, or 81 percent of the entire dataset. These commodities, in descending order of total record count, are: cement (176), petroleum (149), gold (131), iron and steel (119), copper (103), silver (75), natural gas (51), zinc (39), lead (37), calcium carbonate (27), coal (23), antimony (20), molybdenum (19), silica (19), bauxite (18), nickel (16), gypsum (14), nitrates (13), boron (12), and iodine (12). Note that these are among the region's best-known produced mineral commodities; however, it is also important to note that this is not a count of unique facilities but rather is a count of total data records. Some of these records may indicate double or multiple counting across facilities, as some mines produce multiple metal ores and concentrates from polymetallic deposits, and some mineral processing plants produce multiple different metals and or multiple single-metal products.

\section{Oil and gas field center points-OG_CENTER feature class}

More than 2,800 oil and gas field center points were derived from two maps showing the regional geology, oil and gas fields, and geological provinces of South America and the Caribbean, and were merged to create the $O G_{-}$CENTER feature class. The original sources of the oil and gas field data were from the 1997 (South America) and 2002 (Caribbean, Central America, and Mexico) Petroconsultants International Data Corp. petroleum database, as published in USGS OpenFile Reports 97-470-D and 97-470-K, respectively (Schenk and others, 1999; French and Schenk, 2004). These data do not contain attribute information on production or installed production capacity, which are included in the data from Volume III of the Minerals Yearbook in the MINFAC_LAC feature class. Therefore, this feature class represents a greater number of individual field points - which are included to show the overall areal extent of major oil and gas fields within the region - than are included in Volume III. The records shown in Volume III represent those fields for which country specialists had access to specific capacity data, either for individual fields or aggregated across an entire company or country.

\section{Mineral exploration and development sites and other mineral resources-B_MIN_EXPLORE feature dataset}

The feature dataset $B \_M I N \_E X P L O R E$ contains vector point data on mineral exploration sites (EXPLORE_LAC feature class) and vector polygon data on geologic tracts assessed for having the greatest porphyry copper mineral potential. Table 10 shows the individual feature classes within this feature dataset. 
Table 10. Data feature classes within the $B \_M I N \_E X P L O R E$ feature dataset of the file geodatabase $L A C \_I n d u s t \_I n f r a . g d b$.

\begin{tabular}{llr}
\hline \multicolumn{1}{c}{ Feature class name } & Feature class name in geospatial PDF map & Description \\
\hline EXPLORE_LAC & Mineral exploration and development sites & $\begin{array}{c}\text { Vector point data on mineral exploration sites } \\
\text { within Latin America and the Caribbean. }\end{array}$ \\
COAL_AREAS & Coal resources & Areas of coal occurrence. \\
CU_PORPH_TRACTS & Undiscovered porphyry copper resources & $\begin{array}{r}\text { Vector polygon data for tracts having the } \\
\text { greatest porphyry copper mineral potential. }\end{array}$ \\
\hline
\end{tabular}

\section{Mineral exploration and development sites- EXPLORE_LAC feature class}

Selected mineral exploration sites are included as a dataset to provide a regional overview of major mineral exploration sites in exploration or developmental stages. NMIC analysts annually collect and analyze global exploration data and publish a report that reviews worldwide exploration trends. These annual reviews provide data on exploration budgets by region and mineral commodity, identify significant mineral discoveries, and discuss governmental programs or regulatory actions (Wilburn and Karl, 2016). The exploration data contained in EXPLORE_LAC feature class is data from NMIC annual reviews researched using publicly accessible sources to confirm current mineral commodities of interest, project type, location, operational status, primary name, and primary ownership. Financial information on the level of capital or foreign investment into an exploration site or project is not included in this report.

A master global list of mineral exploration sites (not included as part of this report owing to the presence of a significant amount of proprietary data from a subscription service), analyzed by the NMIC for calendar year 2015 , totaled 1,930 mineral exploration sites worldwide, with Latin America and the Caribbean accounting for approximately 340, or 18 percent. This feature class accounts for an approximate "top 100" and includes only those sites for which the NMIC had been tracking their exploration activity via public information separate from any propeietary sources of information. About two-thirds of the LAC sites in the master list reflect global trends of exploration, in which half the exploration activity globally is the exploration for and the identification of gold and silver deposits, and this trend is true within this dataset as well. Exploration for base metals was the next largest category, accounting for nearly an additional 80 sites, or about 20 percent.

Among global regions Latin America, since 2005, has had the largest exploration budget in nominal U.S. dollars. In 2015, the value of the region's exploration budget was approximately $\$ 2.5$ billion, representing 25 percent of the world's total. This total, while still greater than for any other region identified by the USGS, was significantly less than the all-time high of almost $\$ 5.3$ billion in 2012. A significant portion, 46 percent, of all sites within Latin America and the Caribbean were early-stage discoveries, whereas exploration at producing sites (commonly for mine expansions) accounted for 31 percent (Wilburn and Karl, 2016).

Table 11 describes the user-defined data attribute fields in the feature class. The full mineral exploration site feature class, as well as metadata explaining all attribute field values, codes, and abbreviations, is available as a USGS data release (Baker and Wilburn, 2016) through the USGS ScienceBase data release page, available at https://doi.org/10.5066/ F7GQ6VWG.

The project type field "PROJTYPE" indicates the stage of exploration or development activity at a site. Different companies may report terms with different meanings but for the purposes of this report, these terms are defined in table 12 and are shown in temporal rather than alphabetical order.

Table 13 shows summary statistics on the total number of exploration projects by country and project type included in the exploration dataset for this report. The listed mineral commodity is the major exploration target for a particular site. Exploration and development work is extremely site-specific and is controlled by a range of geologic, economic, environmental, and social factors. Frequently, especially for metallic mineral commodities, there are additional metallic targets owing to the geology of any given ore deposit. However, depending on the stage of exploration, not all targeted minerals known to occur at a site will be present in sufficient quantities for economic feasibility for potential extraction. Often projects may be more narrowly developed in later stages to a specific mineral commodity or a subset of known mineral resources. Conversely, even if a mineral resource occurs in sufficient quantities at a particular site, the feasibility of development may be limited owing to economic factors (such as a price crash on major international exchanges, resulting in decreased funding potential from investors), environmental or social concerns (local, intra-, and international opposition), or physical inaccessibility (distance from major transportation networks). 
Table 11. Description of user-defined attribute fields in the mineral exploration and development sites feature class EXPLORE_LAC.

[ID, identification; GENC, Geopolitical Entities, Names, and Codes]

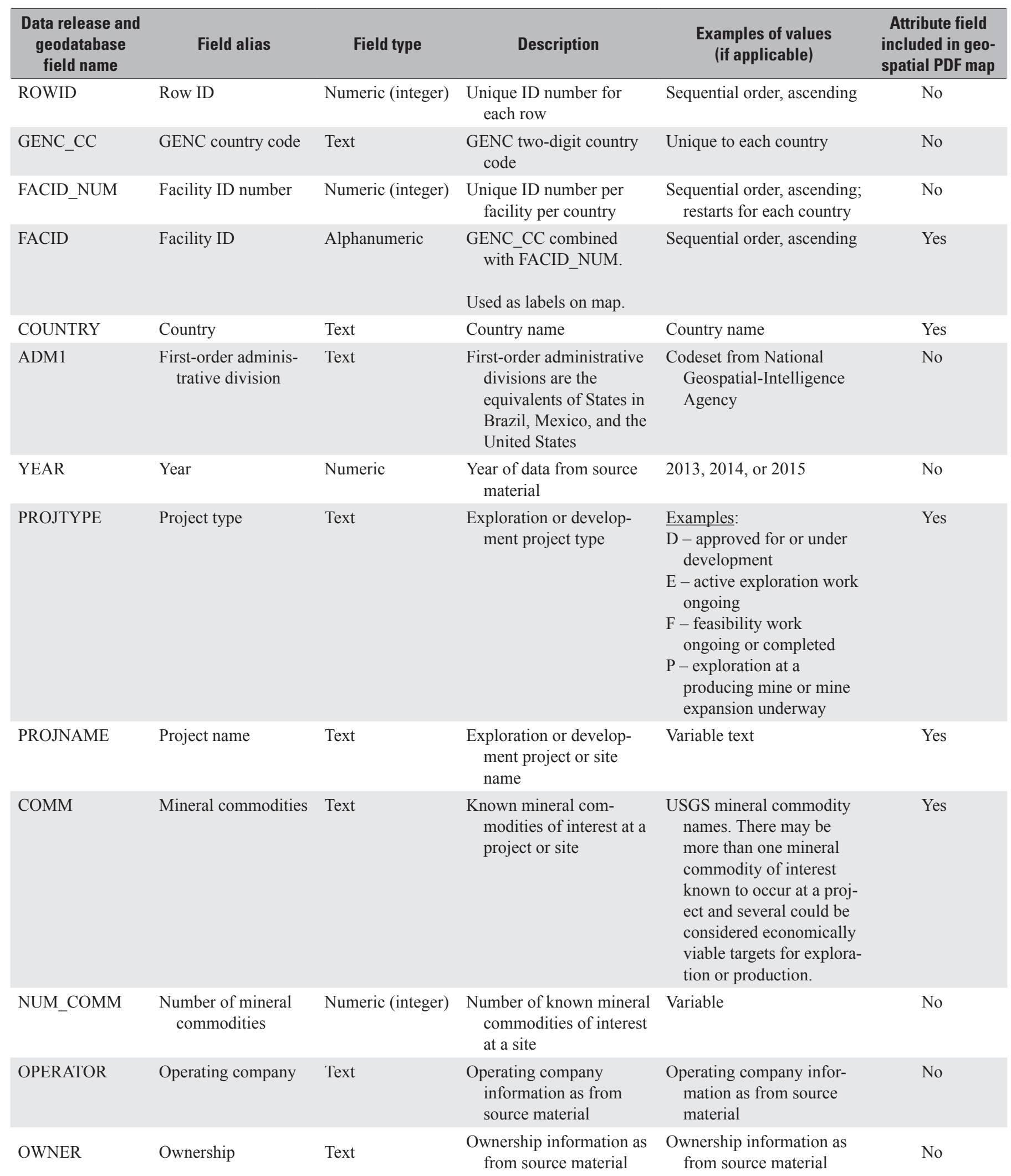


Table 11. Description of user-defined attribute fields in the mineral exploration and development sites feature class EXPLORE_LAC.-Continued

[ID, identification; GENC, Geopolitical Entities, Names, and Codes]

\begin{tabular}{llllll}
\hline $\begin{array}{c}\text { Data release and } \\
\text { geodatabase } \\
\text { field name }\end{array}$ & Field alias & Field type & Description & $\begin{array}{c}\text { Examples of values } \\
\text { (if applicable) }\end{array}$ & $\begin{array}{c}\text { Attribute field } \\
\text { included in geo- } \\
\text { spatial PDF map }\end{array}$ \\
\hline LOCACC & Locational accuracy & Text & $\begin{array}{c}\text { Accuracy of the given } \\
\text { coordinates for the } \\
\text { facility }\end{array}$ & $\begin{array}{l}\text { ・A-Approximate location } \\
\text { - E- Exact location }\end{array}$ & No \\
\hline DDLAT & $\begin{array}{c}\text { Latitude in decimal } \\
\text { degrees }\end{array}$ & Numeric & $\begin{array}{c}\text { Latitude in decimal } \\
\text { degrees }\end{array}$ & Variable & No \\
\hline DDLONG & $\begin{array}{c}\text { Longitude in decimal } \\
\text { degrees }\end{array}$ & Numeric & $\begin{array}{c}\text { Longitude in decimal } \\
\text { degrees }\end{array}$ & Variable & No \\
\hline SOURCEID & Source / reference ID & Text & Source index number & $\begin{array}{c}\text { Internal reference to } \\
\text { sources for USGS }\end{array}$ & No \\
\hline
\end{tabular}

Table 12. Description of user-defined attribute field "PROJTYPE" in the mineral exploration and development sites feature class EXPLORE_LAC.

\begin{tabular}{|c|c|c|}
\hline $\begin{array}{l}\text { PROJTYPE } \\
\text { abbreviation }\end{array}$ & Field alias & Explanation \\
\hline $\mathrm{E}$ & Active exploration work ongoing & $\begin{array}{l}\text { May include a range of exploration work, } \\
\text { including drilling for assay samples or } \\
\text { mineral deposit delineation work to determine } \\
\text { spatial and geologic characteristics of the } \\
\text { deposit. }\end{array}$ \\
\hline $\mathrm{F}$ & $\begin{array}{l}\text { Feasibility work ongoing or } \\
\text { completed }\end{array}$ & $\begin{array}{l}\text { Mineral deposit discovered and studies } \\
\text { undertaken to determine economic viability. }\end{array}$ \\
\hline $\mathrm{D}$ & Approved for or under development & $\begin{array}{l}\text { Post-feasibility and permitted to develop a } \\
\text { property having an economically viable } \\
\text { mineral deposit toward becoming a producing } \\
\text { mine. }\end{array}$ \\
\hline $\mathrm{P}$ & $\begin{array}{l}\text { Exploration at a producing mine or } \\
\text { mine expansion underway }\end{array}$ & $\begin{array}{l}\text { Note: any mine expansion may include the other } \\
\text { stages of exploration or development work, } \\
\text { depending on the stage of mine expansion. }\end{array}$ \\
\hline
\end{tabular}


Table 13. Total counts of selected mineral exploration and development sites in Latin America and the Caribbean, by country and project type, 2013-15, from the EXPLORE_LAC feature class.

$[\mathrm{D}$, approved for or under development; E, active exploration work ongoing; F, feasibility work ongoing or completed; P, exploration at a producing mine or mine expansion underway]

\begin{tabular}{|c|c|c|c|c|c|}
\hline \multirow{2}{*}{$\begin{array}{l}\text { Country and primary mineral commodities } \\
\text { at an exploration site }\end{array}$} & \multicolumn{4}{|c|}{ Project type } & \multirow{2}{*}{$\begin{array}{c}\text { Grand } \\
\text { total }\end{array}$} \\
\hline & D & $\mathbf{E}$ & $\mathbf{F}$ & $\mathbf{P}$ & \\
\hline \multicolumn{6}{|c|}{ Argentina } \\
\hline Copper (also with gold, molybdenum, silver) & & 1 & 4 & & 5 \\
\hline Gold (also with copper, silver, lead, and zinc) & & 1 & & 2 & 3 \\
\hline Lithium & & 3 & 1 & & 4 \\
\hline Natural gas, shale oil & & 1 & & & 1 \\
\hline Silver (also with lead and zinc) & & 1 & 1 & & 2 \\
\hline Triuranium octoxide $\left(\mathrm{U}_{3} \mathrm{O}_{8}\right)$ & & 1 & 1 & & 2 \\
\hline Argentina subtotal & & 8 & 7 & 2 & 17 \\
\hline \multicolumn{6}{|c|}{ Bolivia } \\
\hline Lithium & 1 & & & & 1 \\
\hline Silver, tin, zinc & & & & 1 & 1 \\
\hline Bolivia subtotal & 1 & & & 1 & 2 \\
\hline \multicolumn{6}{|c|}{ Brazil } \\
\hline Bauxite & & & 1 & & 1 \\
\hline Copper (gold and silver) & 1 & 1 & 1 & & 3 \\
\hline Gold & & 2 & & 3 & 5 \\
\hline Iron ore & 3 & & 5 & & 8 \\
\hline Phosphate & & & 4 & & 4 \\
\hline Sulfate of potash & & 1 & & & 1 \\
\hline Brazil subtotal & 4 & 4 & 11 & 3 & 22 \\
\hline \multicolumn{6}{|c|}{ Chile } \\
\hline Copper & 1 & 6 & 10 & 2 & 19 \\
\hline Gold, silver & & 1 & & 1 & 2 \\
\hline Iron ore & 1 & & 2 & 1 & 4 \\
\hline Silver, gold, antimony & & & & 1 & 1 \\
\hline Chile subtotal & 2 & 7 & 12 & 5 & 26 \\
\hline \multicolumn{6}{|c|}{ Colombia } \\
\hline Gold (also with silver) & & 2 & & 1 & 3 \\
\hline Colombia subtotal & & 2 & & 1 & 3 \\
\hline \multicolumn{6}{|c|}{ Ecuador } \\
\hline Copper (also with gold and silver) & & & 1 & & 1 \\
\hline Ecuador subtotal & & & 1 & & 1 \\
\hline \multicolumn{6}{|c|}{ French Guiana } \\
\hline Gold & & & 1 & & 1 \\
\hline French Guiana subtotal & & & 1 & & 1 \\
\hline \multicolumn{6}{|c|}{ Guyana } \\
\hline Bauxite & & & 1 & & 1 \\
\hline Guyana subtotal & & & 1 & & 1 \\
\hline
\end{tabular}


Table 13. Total counts of selected mineral exploration and development sites in Latin America and the Caribbean, by country and project type, 2013-15, from the EXPLORE_LAC feature class. - Continued

[D, approved for or under development; E, active exploration work ongoing; F, feasibility work ongoing or completed; P, exploration at a producing mine or mine expansion underway]

\begin{tabular}{|c|c|c|c|c|c|}
\hline \multirow{2}{*}{$\begin{array}{l}\text { Country and primary mineral commodities } \\
\text { at an exploration site }\end{array}$} & \multicolumn{4}{|c|}{ Project type } & \multirow{2}{*}{$\begin{array}{l}\text { Grand } \\
\text { total }\end{array}$} \\
\hline & D & $\mathbf{E}$ & $\mathbf{F}$ & $\mathbf{P}$ & \\
\hline \multicolumn{6}{|c|}{ Jamaica } \\
\hline Copper, gold & & & 1 & & 1 \\
\hline Jamaica subtotal & & & 1 & & 1 \\
\hline \multicolumn{6}{|c|}{ Mexico } \\
\hline Copper (also with gold and silver) & & 4 & 7 & & 11 \\
\hline Gold (also with silver) & 1 & 1 & & 5 & 7 \\
\hline Lithium & & & 1 & & 1 \\
\hline Silver (also with copper, gold, lead, and zinc) & & 3 & & 4 & 7 \\
\hline Mexico subtotal & 1 & 8 & 8 & 9 & 26 \\
\hline \multicolumn{6}{|c|}{ Peru } \\
\hline Copper (also with gold and silver) & 1 & 2 & 6 & & 9 \\
\hline Heavy mineral sands & & 1 & & & 1 \\
\hline Iron ore & & & 1 & & 1 \\
\hline Phosphate & & & 2 & & 2 \\
\hline Silver, gold & & & & 1 & 1 \\
\hline Peru subtotal & 1 & 3 & 9 & 1 & 14 \\
\hline \multicolumn{6}{|c|}{ Suriname } \\
\hline Bauxite & & & 1 & & 1 \\
\hline Gold & & & & 1 & 1 \\
\hline Suriname subtotal & & & 1 & 1 & 2 \\
\hline Grand total & 9 & 32 & 52 & 23 & 116 \\
\hline
\end{tabular}

\section{Coal occurrence areas_COAL_AREAS feature class}

Coal occurrence areas (also known as coal-bearing areas) are included for general spatial reference as the data feature class COAL_AREAS. The USGS published a compilation of coal data for the Western Hemisphere in 2008 in anticipation of increases in coal consumption and international trade of coal based on projections from the U.S. Energy Information Administration in 2007 (Tewalt and others, 2008). Coal resources were found to be prominent in about 125 areas of 30 countries of the Western Hemisphere. However, the data in this feature class are not suitable for coal resource calculations. The areas included are for general reference, not adjusted for geologic structure, and they do not include coal at depth but instead represent generalized analysis of surficial geology (Tewalt and others, 2008). For example, a large area of Tertiary lignite occurrences exists in northern Peru in the Maranon-Montana Basin of Loreto Department. The extent of this area varies based on source (for example, this region is shown smaller by Weaver and Good [1994]), but the representations in this feature class represent work from across many publications to show total potential for coal occurrences or areas of known occurrences. These areas delineate the known potential for coal occurrences based on surficial geology and do not indicate equal distribution of coal throughout the entire area. Table 14 shows the distribution by rank of the coal resource (type of coal) and table 15 shows the user-defined attribute fields included in the COAL_AREAS feature class. The term "mixed ranks" refers to those coal ranks that in the original data are coal-bearing areas that include a mixture of coal ranks in a range, such as "bituminous to anthracite," or "bituminous to semi-anthracite." Some data points within the original data are also marked with a question mark to denote uncertain rank; these values are included in the mixed values total. A few areas had coal rank as "not reported" and are not included in any specific rank shown. 
Table 14. Number of coal occurrence areas in Latin America and the Caribbean, by coal rank and by country, from the COAL_AREAS feature class.

[Data from Tewalt and others, 2008. Note: in the feature class data table within the geodatabase, users may see values marked with a question mark. These values are of uncertain rank and are included in the mixed value totals]

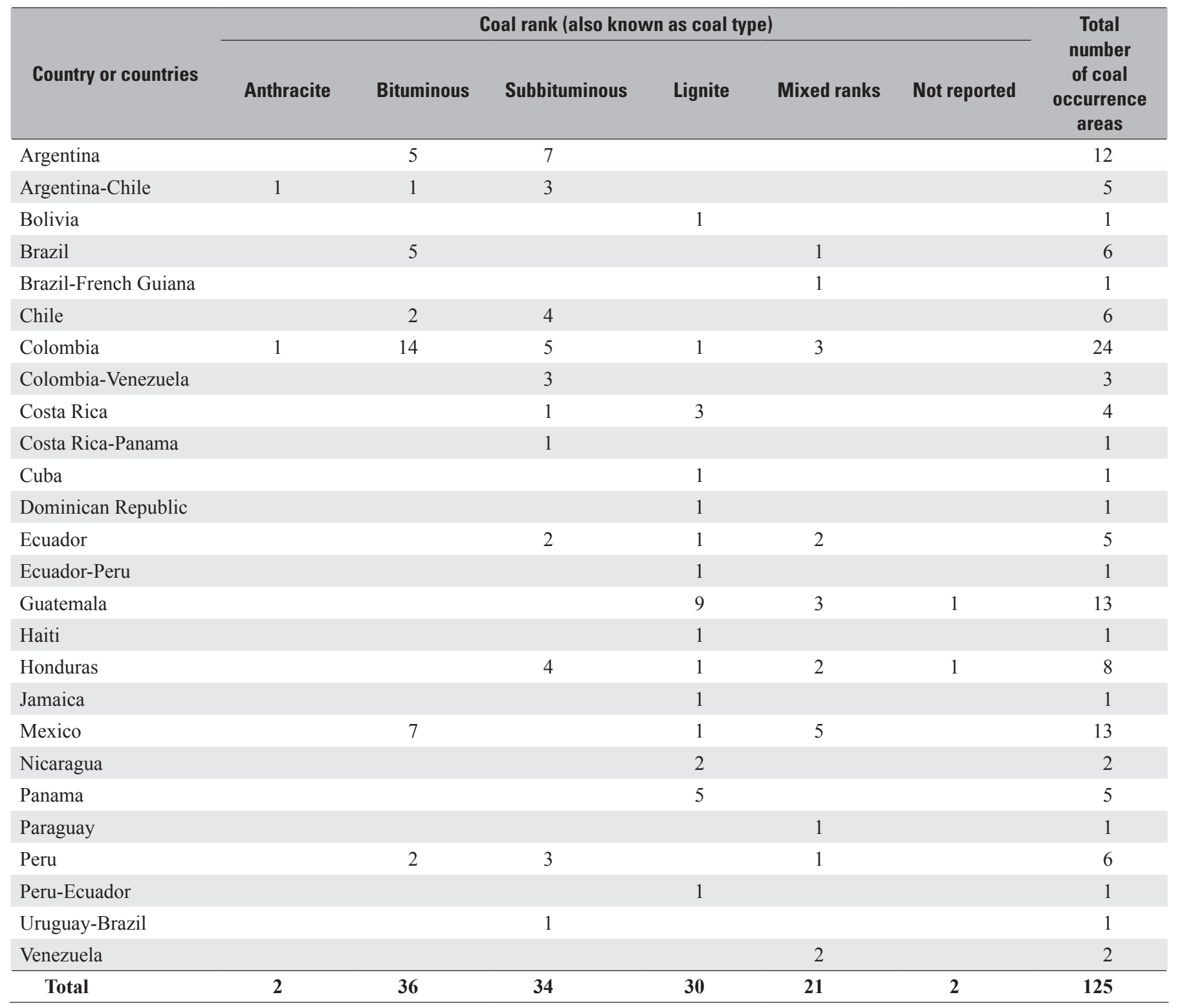


Table 15. Description of user-defined attribute fields in the coal occurrence areas feature class COAL_AREAS.

[From Tewalt and others, 2008. NA, not applicable or not available]

\begin{tabular}{|c|c|c|}
\hline Field alias & $\begin{array}{l}\text { Data field } \\
\text { description }\end{array}$ & $\begin{array}{c}\text { Data field } \\
\text { example values }\end{array}$ \\
\hline FID & Feature identification number & NA \\
\hline Age & $\begin{array}{l}\text { Geologic age of the coal represented } \\
\text { by the polygon }\end{array}$ & $\begin{array}{l}\text { Cenozoic } \\
\text { Quaternary } \\
\text { Tertiary } \\
\text { Pliocene } \\
\text { Miocene } \\
\text { Oligocene } \\
\text { Eocene } \\
\text { Paleocene } \\
\text { Mesozoic } \\
\text { Cretaceous } \\
\text { Jurassic } \\
\text { Triassic } \\
\text { Paleozoic } \\
\text { Permian } \\
\text { Carboniferous } \\
\text { Pennsylvanian } \\
\text { Mississippian } \\
\text { Devonian }\end{array}$ \\
\hline Source & $\begin{array}{l}\text { Source material or original publica- } \\
\text { tion of the data }\end{array}$ & NA \\
\hline Rank & $\begin{array}{l}\text { Apparent rank calculated from } \\
\text { proximate analysis data }\end{array}$ & $\begin{array}{l}\text { Lignite } \\
\text { Subbituminous } \\
\text { Bituminous } \\
\text { Anthracite }\end{array}$ \\
\hline Country & $\begin{array}{l}\text { Country or countries in which a } \\
\text { coal-bearing area occurs }\end{array}$ & $\begin{array}{l}\text { Argentina } \\
\text { Bolivia } \\
\text { Brazil } \\
\text { Chile } \\
\text { Colombia } \\
\text { Costa Rica } \\
\text { Cuba } \\
\text { Dominican Republic } \\
\text { Ecuador } \\
\text { Guatemala } \\
\text { Haiti } \\
\text { Honduras } \\
\text { Jamaica } \\
\text { Mexico } \\
\text { Nicaragua } \\
\text { Panama } \\
\text { Paraguay } \\
\text { Peru } \\
\text { Uruguay } \\
\text { Venezuela }\end{array}$ \\
\hline Continent & $\begin{array}{l}\text { Continent or continents in which a } \\
\text { coal-bearing area occurs }\end{array}$ & $\begin{array}{l}\text { North America } \\
\text { South America }\end{array}$ \\
\hline Min_age & $\begin{array}{l}\text { Minimum age of the coal repre- } \\
\text { sented by the polygon }\end{array}$ & $\begin{array}{l}\text { Same range of values as } \\
\text { Age data field }\end{array}$ \\
\hline Max_age & $\begin{array}{l}\text { Maximum age of the coal repre- } \\
\text { sented by the polygon }\end{array}$ & $\begin{array}{l}\text { Same range of values as } \\
\text { Age data field }\end{array}$ \\
\hline
\end{tabular}




\section{Undiscovered porphyry copper / polymetallic ${ }^{9}$ resources_CU_PORPH_TRACTS feature class}

As part of a global copper mineral resource assessment, the USGS Mineral Resources Program (MRP) analyzed two deposit types which, when combined, account for approximately 80 percent of the world's copper supply; porphyry copper deposits alone account for about 60 percent and sediment-hosted stratabound copper deposits account for the other 20 percent. These two deposit types produce approximately 12 million metric tons of copper per year (Johnson and others, 2014). In 2008 and 2010, the results of a series of mineral resource assessments for porphyry copper deposits conducted in partnership with counterpart scientific agencies in countries across Latin America and the Caribbean region were published (Cunningham and others, 2008; Gray and others, 2014; Hammarstrom and others, 2010).

A total of 43 geographic areas were outlined by the MRP as permissive tracts that may contain undiscovered porphyry copper deposits and prospects within 1 kilometer $(\mathrm{km})$ of the surface: 26 tracts for South America in the Andes Mountains; 12 tracts for Mexico, primarily in the Sierra Madre Occidental stretching from the U.S.-Mexico border to the south-central part of Mexico; and 5 tracts along the mountainous cordillera of Central America and among the islands of the Caribbean. Tracts were delineated primarily on the basis of tectonic setting, occurrences of types of igneous rocks known to host porphyry copper deposits, exploration history, and distribution of known porphyry copper deposits and prospects. Probabilistic estimates of numbers of undiscovered deposits in each tract were combined with appropriate grade and tonnage models to derive probabilistic estimates of the amounts of copper, gold, molybdenum, and silver that could be contained within any undiscovered deposits within a tract.

Table 16 shows characteristics and model estimates for several of the tracts having the greatest estimated mean

\footnotetext{
'In this context, the term "polymetallic" is used to denote mineral resources covering several discrete potential recoverable metals extractable from a mineral resource.
}

metal content for each of the three sub-regions - these tracts and data are those shown in the $C_{-} P O R P H_{-} T R A C T S$ feature class. Other tracts that were assessed, but which contain lower estimates for mean metal content, are included in the feature class shown on the map with gray shading. Attribute data for these other tracts can be accessed through the map document or geodatabase for reference.

The tract having the greatest total expected mean metal content in the entire region is the Chile Eocene-Oligocene Chuquicamata tract along the Argentina-Chile border in the Andes of South America, with an estimated 210 million metric tons (Mt) of copper content, $6.3 \mathrm{Mt}$ of molybdenum content, 1,300 metric tons ( $\mathrm{t}$ ) of gold content, and 70,000 $\mathrm{t}$ of silver content contained in 27 billion metric tons (Gt) of host rock. Among the Caribbean and Central American tracts, the Cocos tract stretching from southern Mexico into Panama but mostly located in Honduras and Nicaragua contains the greatest expected mean metal content, with an expected $53 \mathrm{Mt}$ of copper, 1.4 Mt of molybdenum, 1,300 t of gold, and 18,000 t of silver contained in $11 \mathrm{Gt}$ of host rock. The leading Mexican tract is the Sierra Madre Occidental (West) tract, stretching from the U.S.-Mexico border to the Mexican State of Sinaloa, with an estimated $48 \mathrm{Mt}$ of copper, 1.3 Mt of molybdenum, 1,200 t of gold, and 16,000 $\mathrm{t}$ of silver contained in $9.9 \mathrm{Gt}$ of host rock.

Tracts having the greatest expected mean metal content are not necessarily those with the greatest number of known or undiscovered deposits. For South America, the Peru-Ecuador middle-late Miocene La Granja tract has the greatest number of undiscovered deposits (15) that could occur based on the model, yet the tract overall ranks third for expected mean copper content. However, for Mexico and the Caribbean and Central America, the Sierra Madre Occidental (West) and Cocos tracts (those with the highest expected copper content) do contain the greatest number of undiscovered deposits, 13 and 14, respectively. The permissive tracts listed in table 16 range in area from about 3,000 to 200,000 square kilometers $\left(\mathrm{km}^{2}\right)$. 
Table 16. Undiscovered porphyry copper tracts assessed by the U.S. Geological Survey, containing the greatest estimated mean undiscovered metal content in the Caribbean and Central America, Mexico, and South America, 2008-10, from the CU_PORPH_TRACTS feature class.

[Data from Cunningham and others, 2008; Hammarstrom and others, 2010; and Gray and others, 2014. Tracts identified contain the greatest total metallic resource estimates and the greatest number of tota estimated undiscovered and known deposits. ENUD, estimated mean number of undiscovered deposits; ID, identification. Total number of deposits is rounded to two significant digits]

\begin{tabular}{|c|c|c|c|c|c|c|c|c|c|c|c|c|}
\hline \multirow[b]{2}{*}{ Tract ID } & \multirow[b]{2}{*}{ Coded ID } & \multirow[b]{2}{*}{ Tract name } & \multirow[b]{2}{*}{$\begin{array}{l}\text { Country / } \\
\text { countries }\end{array}$} & \multirow[b]{2}{*}{$\begin{array}{l}\text { Assessment } \\
\text { country or } \\
\text { region }\end{array}$} & \multicolumn{3}{|c|}{ Deposits } & \multicolumn{5}{|c|}{$\begin{array}{l}\text { Estimated mean undiscovered metal content and } \\
\text { total host-rock tonnage (thousand metric tons) }\end{array}$} \\
\hline & & & & & ENUD & $\begin{array}{l}\text { Number } \\
\text { of known } \\
\text { deposits }\end{array}$ & $\begin{array}{c}\text { Total } \\
\text { number } \\
\text { of } \\
\text { deposits }\end{array}$ & Copper & $\begin{array}{l}\text { Molyb- } \\
\text { denum }\end{array}$ & Gold & Silver & $\begin{array}{c}\text { Total } \\
\text { host-rock } \\
\text { tonnage }\end{array}$ \\
\hline MX-L2 & $003 \mathrm{pCu} 3007$ & $\begin{array}{l}\text { Sierra Madre Occidental } \\
\quad \text { (West) }\end{array}$ & Mexico & Mexico & 13 & 15 & 28 & 48,000 & 1,300 & 1.2 & 16 & $9,900,000$ \\
\hline MX-T3 & $003 \mathrm{pCu} 3011$ & Southwest Mexico & Mexico & Mexico & 9.6 & 3 & 13 & 37,000 & 1,000 & 0.940 & 12 & $7,500,000$ \\
\hline MX-L3 & 003pCu3008 & Laramide Central Plateau & Mexico & Mexico & 5.5 & 0 & 6 & 20,000 & 560 & 0.51 & 6.5 & $4,100,000$ \\
\hline MX-L1 & $003 \mathrm{pCu} 3006$ & $\begin{array}{l}\text { Western Mexican Basin } \\
\text { and Range }\end{array}$ & Mexico & Mexico & 4.2 & 1 & 5 & 16,000 & 460 & 0.400 & 5.6 & $3,300,000$ \\
\hline MX-T2 & 003pCu3009 & Tertiary Central Plateau & Mexico & Mexico & 2.5 & 0 & 3 & 9,600 & 260 & 0.250 & 3.1 & $1,900,000$ \\
\hline MX-T1 & $003 \mathrm{pCu} 3010$ & Eastern Alkaline Province & Mexico & Mexico & 2.2 & 0 & 2 & 6,700 & 39 & 0.49 & 2.2 & $1,300,000$ \\
\hline SA10abPC & 005pCu010b & $\begin{array}{l}\text { Chile Eocene-Oligocene } \\
\text { Chuquicamata }\end{array}$ & $\begin{array}{l}\text { Argentina- } \\
\text { Chile }\end{array}$ & South America & 6 & 10 & 16 & 210,000 & 6,300 & 1.3 & 70 & $27,000,000$ \\
\hline SA14bPC & $005 \mathrm{pCu} 014 \mathrm{~b}$ & $\begin{array}{l}\text { Chile Miocene-Pliocene } \\
\text { El Teniente }\end{array}$ & Chile & South America & 1.9 & 2 & 3.9 & 69,000 & 2,000 & 0.44 & 24 & $8,900,000$ \\
\hline SA06PC & $005 \mathrm{pCu} 006$ & $\begin{array}{l}\text { Peru-Ecuador middle-late } \\
\text { Miocene La Granja }\end{array}$ & Peru-Ecuador & South America & 15 & 12 & 27 & 49,000 & 1,200 & 1.2 & 16 & $9,700,000$ \\
\hline SA08PC & $005 \mathrm{pCu} 008$ & $\begin{array}{l}\text { Chile-Peru Paleocene- } \\
\text { Eocene Toquepala }\end{array}$ & Chile-Peru & South America & 12 & 12 & 24 & 43,000 & 1,100 & 1 & 14 & $8,400,000$ \\
\hline SA13bPC & 005pCu013b & $\begin{array}{l}\text { Argentina-Chile } \\
\text { Miocene-Pliocene } \\
\text { Los Pelambres }\end{array}$ & $\begin{array}{l}\text { Argentina- } \\
\text { Chile }\end{array}$ & South America & 6.4 & 2 & 8.4 & 22,000 & 560 & 0.52 & 7 & $4,300,000$ \\
\hline CA_CARIB_T2 & $003 \mathrm{pCu} 4004$ & Cocos & $\begin{array}{l}\text { Central } \\
\text { America }\end{array}$ & $\begin{array}{l}\text { Central } \\
\text { America } \\
\text { and the } \\
\text { Caribbean }\end{array}$ & 14 & 2 & 16 & 53,000 & 1,400 & 1.3 & 18 & $11,000,000$ \\
\hline
\end{tabular}


Table 16. Undiscovered porphyry copper tracts assessed by the U.S. Geological Survey, containing the greatest estimated mean undiscovered metal content in the Caribbean and Central America, Mexico, and South America, 2008-10, from the CU_PORPH_TRACTS feature class._-Continued

[Data from Cunningham and others, 2008; Hammarstrom and others, 2010; and Gray and others, 2014. Tracts identified contain the greatest total metallic resource estimates and the greatest number of total estimated undiscovered and known deposits. ENUD, estimated mean number of undiscovered deposits; ID, identification. Total number of deposits is rounded to two significant digits]

\begin{tabular}{|c|c|c|c|c|c|c|c|c|c|c|c|c|}
\hline \multirow[b]{2}{*}{ Tract ID } & \multirow[b]{2}{*}{ Coded ID } & \multirow[b]{2}{*}{ Tract name } & \multirow[b]{2}{*}{$\begin{array}{l}\text { Country / } \\
\text { countries }\end{array}$} & \multirow[b]{2}{*}{$\begin{array}{l}\text { Assessment } \\
\text { country or } \\
\text { region }\end{array}$} & \multicolumn{3}{|c|}{ Deposits } & \multicolumn{5}{|c|}{$\begin{array}{l}\text { Estimated mean undiscovered metal content and } \\
\text { total host-rock tonnage (thousand metric tons) }\end{array}$} \\
\hline & & & & & ENUD & $\begin{array}{l}\text { Number } \\
\text { of known } \\
\text { deposits }\end{array}$ & $\begin{array}{c}\text { Total } \\
\text { number } \\
\text { of } \\
\text { deposits }\end{array}$ & Copper & $\begin{array}{l}\text { Molyb- } \\
\text { denum }\end{array}$ & Gold & Silver & $\begin{array}{c}\text { Total } \\
\text { host-rock } \\
\text { tonnage }\end{array}$ \\
\hline $\begin{array}{l}\text { CA_CARIB_ } \\
\text { KT1 }\end{array}$ & $003 \mathrm{pCu} 4001$ & Santiago & $\begin{array}{l}\text { Caribbean } \\
\text { islands, } \\
\text { including } \\
\text { Cuba, } \\
\text { Hispaniola, } \\
\text { Jamaica, } \\
\text { Puerto } \\
\text { Rico }\end{array}$ & $\begin{array}{l}\text { Central } \\
\text { America } \\
\text { and the } \\
\text { Caribbean }\end{array}$ & 12 & 4 & 16 & 36,000 & 210 & 2.7 & 12 & $7,400,000$ \\
\hline $\begin{array}{l}\text { CA_CARIB_- } \\
\text { KT2 }\end{array}$ & $003 \mathrm{pCu} 4003$ & Chortis & $\begin{array}{l}\text { Mostly } \\
\text { Honduras }\end{array}$ & $\begin{array}{l}\text { Central } \\
\text { America } \\
\text { and the } \\
\text { Caribbean }\end{array}$ & 6.1 & 0 & 6.1 & 23,000 & 640 & 0.57 & 7.3 & $4,600,000$ \\
\hline CA_CARIB_T1 & $003 \mathrm{pCu} 4002$ & Darién & Panama & $\begin{array}{l}\text { Central } \\
\text { America } \\
\text { and the } \\
\text { Caribbean }\end{array}$ & 3.5 & 1 & 4.5 & 14,000 & 400 & 0.34 & 4.4 & $2,900,000$ \\
\hline CA_CARIB_T3 & $003 \mathrm{pCu} 4005$ & Lesser Antilles & $\begin{array}{l}\text { Lesser } \\
\text { Antilles }\end{array}$ & $\begin{array}{l}\text { Central } \\
\text { America } \\
\text { and the } \\
\text { Caribbean }\end{array}$ & 1.1 & 0 & 1.1 & 3,300 & 19 & 0.24 & 1.1 & 680,000 \\
\hline
\end{tabular}




\section{Energy infrastructure-C_ENERGY_INFRA feature dataset}

The feature dataset C_ENERGY_INFRA contains vector point and polyline data feature classes covering the infrastructure relating to the production of electric energy (electric power generating plants and transmission lines), as well as associated infrastructure for the petroleum industries, including pipelines and operational liquefied natural gas terminals. Table 17 shows the individual feature classes within this feature dataset.

\section{Electric power generating facilities- POWER_LAC feature class}

Major electric power generating facilities in the LAC region, also known as powerplants, were researched to present the overall scale and distribution of electric generating power. Extractive industries, including mining and oil and gas extraction, are dependent on locally available and reliable sources of electric energy in large quantities to power their operations. Some countries - such as those in the Southern Cone (Argentina, Brazil, Chile, and Uruguay) — have welldeveloped, internationally connected electric grid systems, capable of generating and distributing electric power for major metropolitan areas and heavy industries. Other countries, notably those in the Caribbean, have smaller grid systems reliant on smaller-capacity generating plants, with industries

Table 17. Data feature classes within the $C_{-} E N E R G Y_{-} I N F R A$ feature dataset of the file geodatabase $L A C_{-}$Indust_Infra.gdb.

\begin{tabular}{ll}
\hline Feature class name & \multicolumn{1}{c}{ Description } \\
\hline POWER_LAC & $\begin{array}{c}\text { Vector point data. Electric power } \\
\text { generating facilities within the region, } \\
\text { including energy source (geothermal, } \\
\text { hydroelectric, nuclear, solar, thermal, } \\
\text { and wind). Thermal energy sources } \\
\text { include coal, gas, and oil-fired power- } \\
\text { plants. }\end{array}$ \\
\hline OG_CONC_AREAS & $\begin{array}{l}\text { Oil and gas concession leasing areas } \\
\text { PETRO_PROV }\end{array}$ \\
\hline TRANSMISSION & $\begin{array}{c}\text { Vector polyline data. Electric power } \\
\text { transmission lines. No attribute data; } \\
\text { provided only for visual spatial } \\
\text { reference. }\end{array}$ \\
\hline LNG & $\begin{array}{l}\text { Vector point data. Liquefied natural } \\
\text { gas terminals, including facility type } \\
\text { (regasification or liquefaction). }\end{array}$ \\
\hline PIPELINES & $\begin{array}{l}\text { Vector polyline data. Oil and natural gas } \\
\text { pipelines. No attribute data; provided } \\
\text { only for visual spatial reference. Not } \\
\text { broken into specific product pipelines. }\end{array}$ \\
\hline
\end{tabular}

commonly generating their own electric power onsite (McIntyre and others, 2016). Using publicly available geospatial and non-geospatial sources, a dataset with over 500 data points was created based on information available from the governments of foreign countries regarding powerplants, their locations, their installed capacities, and energy sources. Data were collected from a range of national authorities, including:

- Argentina-Ministerio de Energía y Minería

- Bolivia-Autoridad de Fiscalizatión y Control de Electricidad

- Brazil-Agência Nacional de Energia Eléctrica

- Chile-Ministerio de Energía

- Ecuador-Corporación Eléctrica del Ecuador

- Mexico-Instituto Nacional de Estadística y Geografíca

- Peru-Ministerio de Energía y Minas

In some cases, such as data for Brazil and Chile, the criterion for inclusion in this dataset was facilities having the greatest installed electric power generating capacities: for Brazil, greater than or equal to 400 megawatts (MW), and for Chile, greater than or equal to $100 \mathrm{MW}$. For other countries, based on available data sources, the criterion was set lower-for example, Peruvian data are those facilities having an installed electric power generating capacity greater than or equal to $30 \mathrm{MW}$. However, for smaller countries, including those in Central America, that do not contain facilities as large as in other countries, facilities were included based on available research. Some data gaps may be present depending on the country. Table 18 highlights the main feature attributes and data fields within the electric power generating facility feature class.

In 2010, the World Bank reported that six countries within the LAC region accounted for 84 percent of the region's total electric power generating capacity in 2010: Brazil (36 percent), Mexico (21 percent), Argentina ( 9 percent), Venezuela (9 percent), Colombia (5 percent), and Chile (4 percent) (Yepez-García and others, 2010). In 2010, hydroelectric dams represented 65 percent of all electric power capacity in the region, with a total installed capacity nearing 153 gigawatts (Wheeler, 2012). In 2013, the Inter-American Development Bank stated that, for its member states, installed power capacity was relatively unchanged from 2010: Brazil, 37 percent; Mexico, 19 percent; and the Southern Cone [Argentina, Chile, Paraguay, and Uruguay], 18 percent (Flavin and others, 2014).

Paraguay is a significant producer of hydroelectricity owing to the Itaipu Binacional dam that straddles the BrazilParaguay border - the largest electric power generating facility in the LAC region and the second largest power producing facility in the world, with a total installed capacity of 14 gigawatts. Most of Paraguay's production is immediately sold back to Brazil (Yepez-García and others, 2010). For this reason, 
Table 18. Description of user-defined attribute fields in the electric power generating facilities data feature class POWER_LAC.

[ID, identification; GENC, Geopolitical Entities, Names, and Codes]

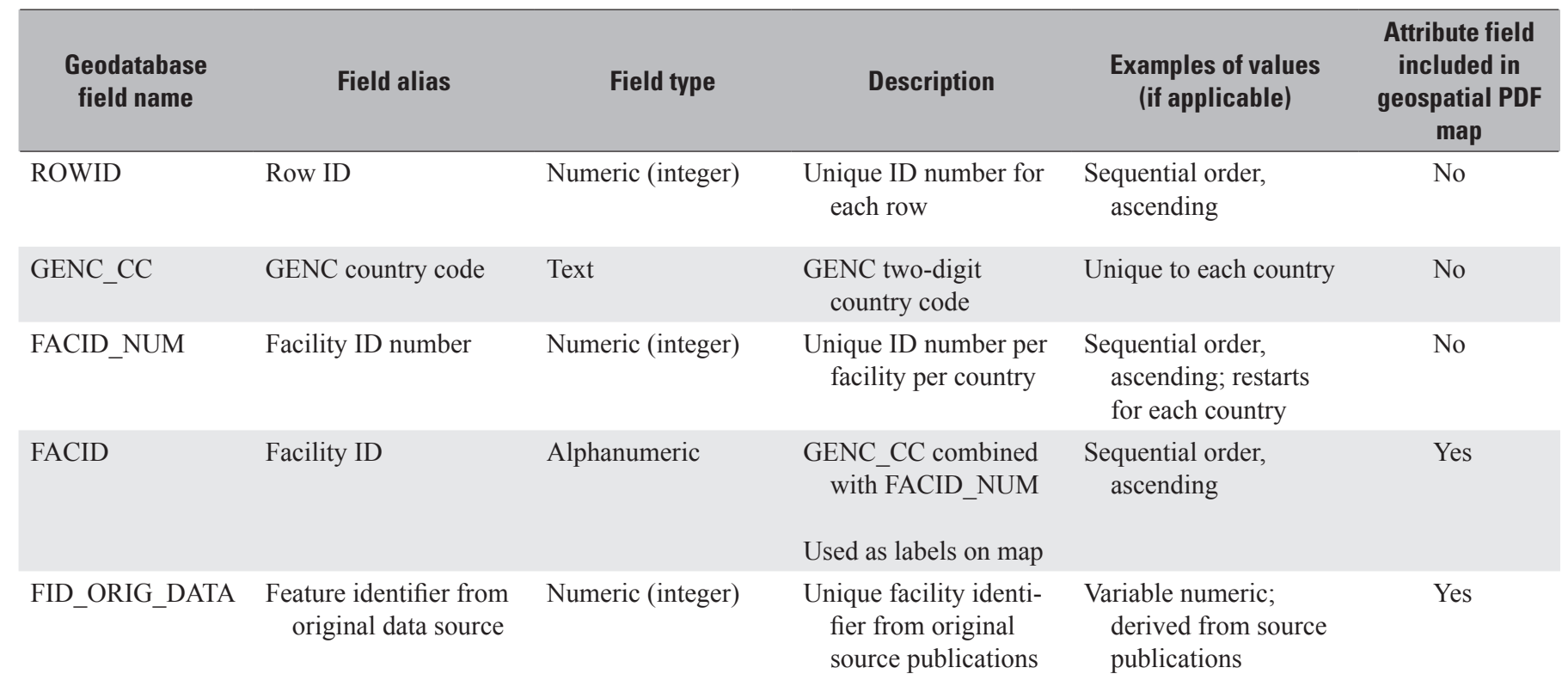

\begin{tabular}{|c|c|c|c|c|c|}
\hline COUNTRY & Country & Text & Country name & Country name & Yes \\
\hline ADM1 & $\begin{array}{l}\text { First-order administra- } \\
\text { tive division }\end{array}$ & Text & $\begin{array}{l}\text { First-order administra- } \\
\text { tive divisions are the } \\
\text { equivalents of States } \\
\text { in Brazil, Mexico, } \\
\text { and the United States }\end{array}$ & $\begin{array}{l}\text { Codeset from } \\
\text { National Geospatial- } \\
\text { Intelligence Agency }\end{array}$ & No \\
\hline
\end{tabular}

\begin{tabular}{|c|c|c|c|c|c|}
\hline PLANTNAME & $\begin{array}{l}\text { Electric power generat- } \\
\text { ing facility name }\end{array}$ & Text & Facility name & Variable text & Yes \\
\hline CITY & City & Text & $\begin{array}{l}\text { Location of electric } \\
\text { power generating } \\
\text { facility }\end{array}$ & Variable text & No \\
\hline ENERGY_TYPE & Energy source category & Text & $\begin{array}{l}\text { Primary energy source } \\
\text { for electric power } \\
\text { generation }\end{array}$ & $\begin{array}{l}\text { - Geothermal } \\
\text { - Hydroelectric } \\
\text { - Nuclear } \\
\text { - Solar } \\
\text { - Thermal } \\
\text { - Wind }\end{array}$ & Yes \\
\hline OPERATOR & Facility operator & Text & $\begin{array}{l}\text { Operator of the facility, } \\
\text { if known }\end{array}$ & Variable text & Yes \\
\hline
\end{tabular}


Table 18. Description of user-defined attribute fields in the electric power generating facilities data feature class POWER_LAC.-Continued

[ID, identification; GENC, Geopolitical Entities, Names, and Codes]

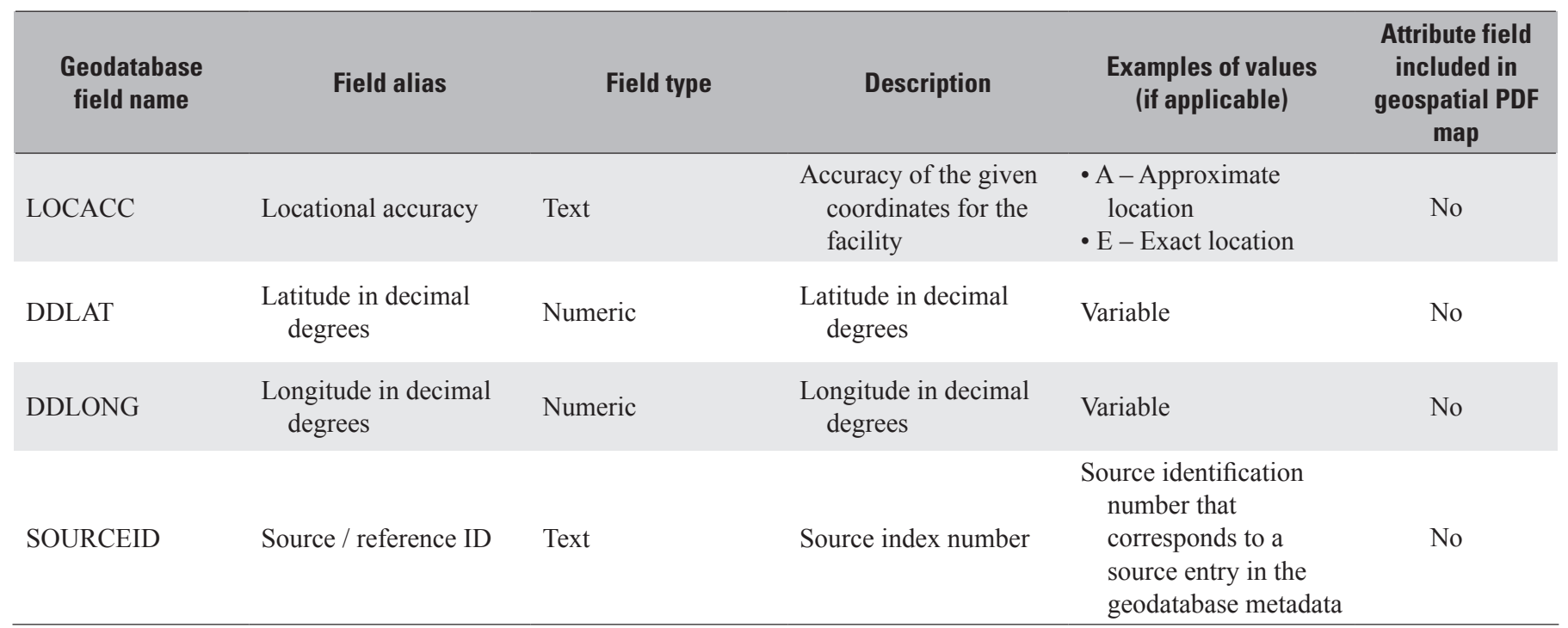

Itaipu is included in the dataset as a Brazilian facility, although it is shared by the two countries. This situation is similar for the Acaray (listed as a primarily Brazilian facility in this dataset) and Yacyreta Binacional (Argentina) plants, which also occur on waterways sharing the border of Paraguay. In 2010, Brazil accounted for 74 percent of all hydroelectric power generated in the LAC region (Wheeler, 2012), and as of 2015, had 92 gigawatts of installed hydroelectric power capacity, accounting for 65 percent of the country's overall energy needs (International Hydropower Association, 2016).

Other energy sources used to produce electricity for the region account for a smaller share of total installed capacity. Six nuclear reactors were operational in the region as of 2016. They are, by country: (1) Atucha I and II and Embalse in Argentina; (2) Angra I and II in Brazil, both co-located at Praia de Itaorna, Rio de Janeiro State; and (3) Laguna Verde in Mexico. Angra III in Brazil is under construction and has not yet been brought online. Powerplants using fossil fuels are categorized in this report under the "thermal" category. The only country with significant coal-fired plant development plans is Colombia, which possesses the region's largest coal reserves and remains the region's largest coal exporter (Yepez-García and others, 2010). Petroleum-fueled power generating plants, which use fuel oil or diesel, account for the majority of smaller capacity facilities, concentrated mostly in island countries in the Caribbean, as well as in French Guiana, Guyana, and Suriname. In 2005, 75 percent of Caribbean countries relied on petroleum-burning power facilities to generate electric power, in contrast to the regional total of 14 percent (Yepez-García, 2010). In 2012, almost a decade later, 41 percent of the Caribbean's installed power capacity was reliant on fuel oil and diesel as a primary energy source, with 47 percent reliant on natural gas (Inter-American Development Bank, 2014).

Large disparities exist relative to electricity access within the countries of Latin America and the Caribbean; access is almost entirely dependent on proximity to either larger metropolitan areas or to large hydroelectric dams. In 2008, Peru had the largest disparity in electrification rates between rural and urban areas: 28 percent versus 96 percent. In addition to Peru, Bolivia, Haiti, Honduras, and Nicaragua each had rural electrification rates under 50 percent (YepezGarcía and others, 2010). Some studies analyzing the power distribution in the region focus on electricity accessibility rates by demographics and population density, however, this does not reflect upon the distribution of power for mining. Mines, especially those in wilderness areas in the Andes, tend to rely on generating their own electric power through relatively smaller-scale diesel generators in addition to connecting to larger transmission grids. Several mines in Chile have been transitioning to renewable energy sources in order to lower their reliance on diesel fuel, including using small-scale solar to partially operate solvent extraction-electrowinning plants (Dixon and Nakagawa, 2016, p. 7).

The lack of diversification among energy types within a country's individual power system can pose problems with consistent generation and distribution of electricity, leading to electric supply shortages intra- and internationally. The heavy reliance on hydroelectricity has been impacted by large-scale regional weather events. The 2016 El Niño in the Pacific Ocean altered rainfall patterns and caused a drought that shut down Venezuela's Guri Dam for an extended period. The dam 
had accounted for 60 percent of the country's power production and the result was widespread power outages that affected major metropolitan areas and industrial facilities (Cawthorne, 2016). Brazil is also very reliant on hydroelectricity and as of 2016 had been experiencing a mutli-year drought that has negatively impacted States with major population centers and industrial activity, including Bahia, Minas Gerais, Pernambuco, Rio de Janeiro, and São Paulo (International Hydropower Association, 2016).

\section{Oil and gas concession leasing areas- OG_CONC_AREAS feature class}

Where data sources were available and reproduceable, oil and gas concession leasing areas were compiled and digitized to create the $O G_{-} C O N C \_A R E A S$ feature class. These areas are included in the geospatial PDF map as a visual spatial reference and do not contain attribute information. Few countries publish comprehensive leasing attribute information in a digital format including details on current lease-holders of concession areas; however some countries, such as Peru, make their geospatial concession footprint data available online (PeruPetro S.A., 2016). Data were obtained from the following foreign government ministries and agencies, where available and applicable:

- Argentina-Ministerio de Energía y Minería, 2017, including both:

- Producción Hidrocarburos Concesiones de Explotación

- Producción Hidrocarburos Lotes de Explotación

- Belize-Ministry of Energy, Science and Technology, and Public Utilities, 2015

- Brazil—Agência Nacional do Petróleo, Gás Natural e Biocombustíveis

- Colombia-Unidad de Planeacion Minero Energetica and Agencia Nacional de Hidrocarburos, 2015

- Dominican Republic-Ministerio de Energía y Minas, 2015

- Guatemala-Ministerio de Energía y Minas, Dirección General de Hidrocarburos, 2007

- Mexico-Comisión Nacional de Hidrocarburos, 2017

- Paraguay_Viceministerio de Minas y Energia, 2016

- Peru-PeruPetro S.A., 2016

Over 5,000 delineated areas (also referred to as blocks) are included and these vary greatly in spatial scale and resolution. Some delineated areas in mountains of Colombia or along the eastern central coast of Mexico may be no larger than $50 \mathrm{~km}^{2}$; other individual blocks may be as large as $30,000 \mathrm{~km}^{2}$ or more. Some countries may only have data on offshore areas, with no available data on inland oil and gas concession leasing areas. Although most countries have delineated blocks for leasing purposes, not all blocks are leased or explored. For example, exploration of Cuba's offshore blocks has been limited to a few nearshore sites off the northern coast, with limited to no exploration pursued in areas held to the west of the country in the Gulf of Mexico (Wacaster and others, 2015). For the entire region, comparing the $O G_{-} C E N T E R$ data feature class_- showing the center points of producing oil and gas fields-against $O G_{-} C O N C_{-} A R E A S$ shows that not all delineated areas open for leasing have actually had discovery or production.

Offshore concession leasing areas are usually within a country's exlcusive economic zone (EEZ), or less than 200 nautical miles offshore. Some areas within this feature class may appear farther than this distance, as the EEZ may have been calculated based on a country's island possessions that are not prominently visible at the scale of the geospatial PDF map. A maritime dispute exists between Colombia and Nicaragua involving significantly overlapping offshore rights within both countries' EEZs, owing to the location of the Colombian department of the Archipelago of San Andrés, Providencia, y Santa Catalina. Such diplomatic disputes prevent further natural resource exploration or extraction (Kashi, 2013).

\section{USGS petroleum provinces_PETRO_PROV feature class}

In the late 1990s, in anticipation of conducting worldwide assessments of petroleum provinces using a consistent total petroleum systems approach, the World Energy Project of the USGS divided the world into 937 geologic provinces to support future assessments of undiscovered hydrocarbon resources (Klett and others, 1997). The PETRO_PROV feature class contains the petroleum provinces that are within this project's study area (including some shared between the United States and Mexico). Petroleum provinces contain common geologic attributes and may include a single dominant structural element, such as a basin or fold belt. Where applicable they follow natural geological boundaries. Within Latin America and the Caribbean, but excluding provinces in the Gulf of Mexico that are entirely within the territorial waters of the United States, there are 159 delineated petroleum provinces, of which 80 are represented on the map. These 80 are those in which oil and gas field-level data were available from the Information Handling Services (IHS) International Exploration and Production Database (IEPD) ${ }^{10}$ (see following section, "Oil and gas cumulative production and rank, recoverable proven plus probable hydrocarbon resources, and undiscovered hydrocarbon resources from IHS IEPD and

\footnotetext{
${ }^{10}$ The IHS International Exploration and Production Database was accessed by USGS researchers when the company conducted business as IHS Global. In July 2016, the parent company of IHS Global, IHS Inc., merged with Markit Ltd. to become IHS Markit.
} 
USGS—D_IHS_USGS_OG_DATA feature dataset" for further discussion).

These petroleum provinces vary greatly in areal extent and typically cross international boundaries. The largest province by areal extent included in this report, the Andean Province, stretches along the Pacific coast of South America from southern Ecuador to the extreme southern tip of Chile. This province surrounds several smaller distinct provinces, such as the Temuco and Altiplano Basins, which were separately identified owing to those regions' specific geologic features. Offshore basins are included, among them the wellknown oil-producing provinces off the coast of Argentina, Brazil, and Uruguay: the Espírito Santo, Campos, Santos, Pelotas, and East Patagonia Basins.

\section{Electric power transmission lines- TRANSMISSION feature class}

Electric power transmission line data were obtained from geospatial directories or online catalogs of foreign countries or digitized from maps representing very broad outlines of the electric power distribution network to create the TRANSMIS$S I O N$ feature class. Transmission lines plotted on the map of this report are not necessarily to scale on-the-ground, nor do they contain any attribute information as to total kilowatt capacity or kilowatt-hours delivered; they are provided as a visual spatial reference to add to the understanding of the region's broader industrial infrastructure. The length of all electric power transmission lines represented in this report totals almost $250,000 \mathrm{~km}$. An integrated regional grid, similar to that of North America, is not fully operating across the entire LAC region. In Central America, construction has begun to create interconnectors between Mexico and Colombia in order to unify the North American and northern South American grid systems (Flavin and others, 2014). Other parts of the region - such as the Caribbean and the Guyanas (French Guiana, Guyana, and Suriname) - are still reliant on fairly low-wattage power generation from oil- and diesel-burning facilities with little international infrastructure for power sharing.

Where applicable and available, data were obtained as geospatial formats or digitized from a variety of foreign governmental sources, including the following ministries and agencies:

- Argentina-Ministerio de Energía y Minería, 2017

- Bolivia-Autoridad de Fiscalización y Control de Electricidad, 2016

- Brazil-Agência Nacional de Energia Eléctrica, 2016

- Chile-Ministerio de Energía, 2017: Sistema de Transmisión Eléctrica (Linea de Transmisión SING, Linea de Transmisión SIC, Linea de Transmisión Aysen)
- Colombia-Unidad de Planeacion Minero Energetica and Ministerio de Minas y Energía

- Ecuador-Corporación Eléctrica del Ecuador, 2014

- Peru-Ministerio de Energía y Minas, 2011

- Venezuela-Corporación Eléctrica Nacional S.A. (CORPOLEC), 2017

\section{Liquefied natural gas terminals—LNG feature class}

Table 19 shows example attribute data of the $L N G$ feature class from the 2016 global directory published by the International Gas Union; the file geodatabase data table contains additional attribute information, including nameplate capacity and latitude and longitude in decimal degrees. In 2014, the International Energy Agency estimated that the global trade of liquefied natural gas (LNG) would rise by 40 percent to 450 billion cubic meters by 2019, and, as part of this increase, that total LNG exports from the United States to the LAC region could climb to approximately 241 million cubic meters, or 8.5 billion cubic feet, a day by 2020 (Burma and Hong, 2014). In a report from 2015 with The Inter-American Dialogue, the Inter-American Development Bank projected that countries within the LAC region will benefit from any U.S. gas boom in the future, given rising gas demand in most countries and the conversion of oil-fired powerplants to burn cheaper and cleaner natural gas. Most countries within the region remain net importers of natural gas (Viscidi and others, 2015, p. 1). Trinidad and Tobago and Peru are the two leading net exporters of LNG, through the four Atlantic LNG terminals at Point Fortin, Trinidad, and the Peru LNG Camisea terminal, respectively (Viscidi and others, 2015, p. 7). These countries had the only operational liquefaction terminal complexes within the LAC region as of 2016; the only other operational liquefaction terminal in the Western Hemisphere was at Kenai, Alaska, U.S. (International Gas Union, 2016, p. 22). Trinidad and Tobago produced 39 percent of the LAC region's total LNG demand in 2014; the majority of Peruvian LNG was shipped to Mexico (Viscidi and others, 2015, p. 7). The 11 regasification terminals within the region convert LNG back into a gaseous state for transportation and consumption: Brazil and Mexico, each with three; Argentina and Chile, each with two; and one in the Dominican Republic.

\section{Oil and gas pipelines-PIPELINES feature class}

Oil and gas pipeline polyline data were obtained from foreign governmental ministries' or agencies' online geospatial infrastructure web portals or derived from existing maps and digitized to compile the PIPELINES feature class. No attribute information is present within this feature class and it is provided for visual spatial reference. Some information on product differentiation is present in original source material, 
Table 19. Active liquefied natural gas terminals in Latin America and the Caribbean, 2016, from the LNG data feature class.

[Data derived from International Gas Union, 2016. km, kilometer; LNG, liquefied natural gas]

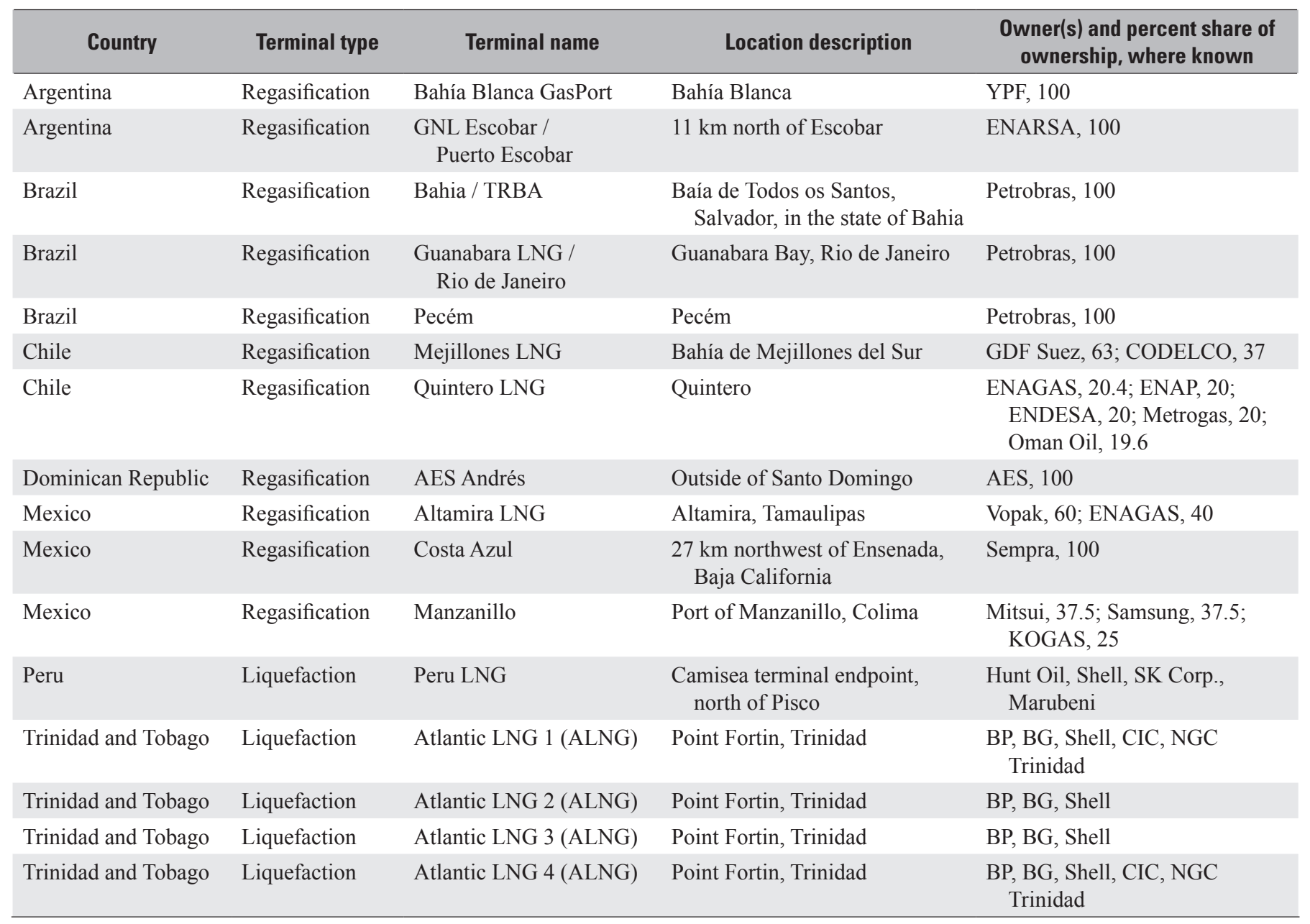

but for including the spatial footprint of the pipelines, all oil and gas pipelines are represented as a single feature class. The total length of all pipeline features in this feature class is over 93,000 km. Data on oil and gas pipelines were collected from a range of foreign governmental or company sources, including:

- Argentina-Ministerio de Energía y Minería, 2017

- Brazil-Agência Nacional de Energia Eléctrica, 2016

- Chile-Ministerio de Energía, 2017

- Mexico-Instituto Nacional de Estadística y Geografía, 2017

- Suriname-Staatsolie Maatschappij Suriname N.V., 2017

- Peru-Instituto Geográfico Nacional, 2015

It is known that Argentina, Colombia, Ecuador, and Venezuela have differentiated product pipelines, depending on the original source and form of the product (for example, gas-only or oil fields with sufficiently exploitable quantities of both oil and gas) as well as the destination market (internal consumption or shipment for export). Peru's Camisea Pipeline begins in the Ucayali Basin in Amazonian Peru at the San Martín gas field and ends at the Pacific Ocean at the Pisco fractioning plant and Peru LNG facility for export. Production from the gas fields began in 2004, and this pipeline continues to supply over 95 percent of Peru's internal demand for gas while exporting more than 5.6 billion cubic meters annually of LNG to Mexico (Oil \& Gas Year Ltd., The, 2015). Other networks of pipelines exist on the Atlantic coast of Argentina, Brazil, and Uruguay, serving that part of the region's major metropolitan markets. One example of a major interntional pipeline is the Cruz del Sur pipeline, operated by Gasoducto Cruz del Sur S.A. Crossing under the Río de la Plata from Punta Lara, Argentina, and eventually reaching Montevideo, Uruguay, the 24-inch-diameter, 57-km-long pipeline is an extension of Argentina's natural gas grid to deliver natural gas to Uruguayan customers (Gasoducto Cruz del Sur S.A., 2017). 
Oil and gas cumulative production and rank, recoverable proven plus probable hydrocarbon resources, and undiscovered hydrocarbon resources from IHS IEPD and USGSD_IHS_USGS_OG_DATA feature dataset

\section{Overview of hydrocarbon data from IHS IEPD and USGS-OG_COUNTRY and OG_PETRO_PROV feature classes}

Working in collaboration with the USGS Energy Resources Program, the NMIC obtained permission from IHS IEPD $^{11}$ to use data from the IHS International Exploration and Production Database (IEPD) on hydrocarbon production within the region (IHS Global Inc., 2016). These data were originally individual records from oil fields or gas-only fields that were then aggregated by the USGS into country or petroleum province totals based on hydrocarbon product or resource category. For this report, the term "oil field" refers to those underground petroleum reservoirs that contain oil, natural gas, and condensate or natural gas liquids; whereas "gas-only" fields contain little to no exploitable oil. Within the geodatabase, the D_IHS_USGS_OG_DATA feature dataset contains two feature classes with extensive data attribute tables, OG_COUNTRY and OG_PETRO_PROV, which contain the IHS IEPD data organized by country or petroleum province, respectively.

Table 20 shows the simplified schema for the userdefined attribute field names for $O G_{-} C O U N T R Y$ and OG_PETRO_PROV within the file geodatabase. These data are organized by cumulative production and recoverable proven plus probable resources based on the following hydrocarbon resource categories:

1. Conventional oil, gas, and condensate from oil fields, shown with the field alias prefix "CONV_"

2. Conventional gas and condensate from gas-only fields, shown with the field alias prefix "CONV_GASO_"

3. Extra-heavy crude resources from oil fields, shown with the field alias prefix "XHC_"

4. Unconventional oil, gas, and condensate resources from oil fields, shown with the field alias prefix "UNCONV_"

\footnotetext{
${ }^{11}$ As stated in the section on petroleum provinces, the IHS International Exploration and Production Database (IEPD) was accessed by USGS Energy Resources Program researchers when the company conducted business as IHS Global. In July 2016, the parent company of IHS Global, IHS Inc., merged with Markit Ltd. to become IHS Markit.
}

There is a fifth grouping of data attribute fields at the end of each table which are not IHS IEPD data but instead are derived from the USGS 2012 world assessment of undiscovered, technically recoverable conventional oil and gas resources (Data Series 69-FF; U.S. Geological Survey World Conventional Resources Assessment Team, 2013). The format is similar although the terminology differs slightly from that of IHS IEPD, using the term "natural gas liquids" (NGL), which includes condensates but which also may include other natural gas liquids. These data also include total oil equivalent (TOE) for all hydrocarbon resources, as well as a generalized category for any offshore resources that are not allocated at a country level. These data do not have a prefix, but begin with the "OO_MCM" data field.

Two USGS-created fields per hydrocarbon resource product category that are not part of the original numeric IHS IEPD or USGS data are included: (a) fields beginning with "CAT," showing a USGS-created categorization schema for simplified cartographic visualization, and (b) fields beginning with "RANK," indicating the USGS-calculated regional rank. "CAT" fields are categorized by magnitude of production, regardless of the units of measurement used within a particular hydrocarbon resource's numeric data fields. Natural gas liquids (from USGS) and oil are reported in million cubic meters, whereas condensate (from IHS IEPD) and gas are reported in billion cubic meters. Data were not converted into one magnitude to preserve original reported data precision.

For example, category " $\mathrm{A}$ " refers to the largest category of production by magnitude, values greater than 10,000 million (or billion) cubic meters. Category "B" refers to values between 1,000 and 9,999 million (or billion) cubic meters. Category "C" refers to values between 100 and 999 million (or billion) cubic meters. Category " $D$ " refers to values between 1 and 99 million (or billion) cubic meters. Category "E" refers to values that are less than one unit (marked as "LT1," meaning less than one million (or billion) cubic meters). The value "NA" denotes when data were not available or applicable. The value "W" denotes when a value is witheld to protect proprietary information or when there is only one field reporting per geographic area (country or petroleum province).

Data records were ranked in order of largest to smallest reported volume of production or resource, either in million or billion cubic meters, and results tabulated in the "RANK" field. Appropriate units are included in the field alias for quick reference as a alias suffix of either "_MCM" or "_BCM." Rankings are regional and based only on those geographic units included in this report (that is, country or petroleum province) and do not reflect global totals of hydrocarbon production. Fields beginning with "CAT" and "RANK" are numerically titled (for example, "CAT1," "RANK1," "CAT2," "RANK2," etc.) and refer to the data column that they immediately follow. 
Table 20. User-defined attribute fields in the OG_COUNTRY and OG_PETRO_PROV data feature classes.

[NA, not applicable; PP, petroleum province]

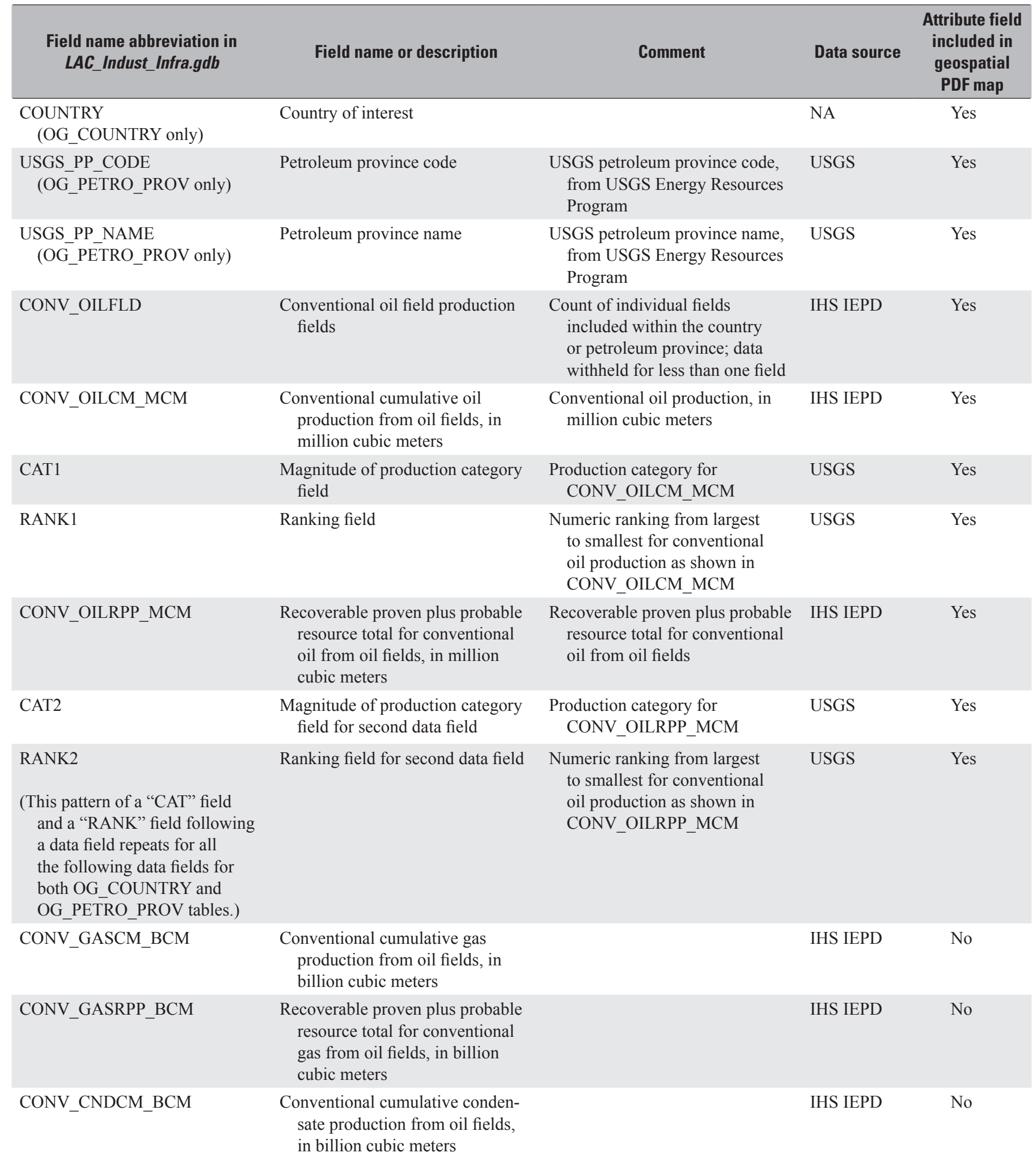


Table 20. User-defined attribute fields in the OG_COUNTRY and OG_PETRO_PROV data feature classes.—Continued

[NA, not applicable; PP, petroleum province]

\begin{tabular}{|c|c|c|c|c|}
\hline $\begin{array}{l}\text { Field name abbreviation in } \\
\qquad A C \_ \text {Indust_Infra.gdb }\end{array}$ & Field name or description & Comment & Data source & $\begin{array}{l}\text { Attribute field } \\
\text { included in } \\
\text { geospatial } \\
\text { PDF map }\end{array}$ \\
\hline CONV_GASOCM_BCM & $\begin{array}{l}\text { Conventional cumulative gas } \\
\text { production from gas-only fields, } \\
\text { in billion cubic meters }\end{array}$ & & IHS IEPD & No \\
\hline CONV_GASO_CNDCM_BCM & $\begin{array}{l}\text { Conventional cumulative conden- } \\
\text { sate production from gas-only } \\
\text { fields, in billion cubic meters }\end{array}$ & & IHS IEPD & No \\
\hline CONV_GASO_CNDRPP_BCM & $\begin{array}{l}\text { Recoverable proven plus probable } \\
\text { resource total for conventional } \\
\text { condensate from gas-only fields, } \\
\text { in billion cubic meters }\end{array}$ & & IHS IEPD & No \\
\hline XHC_OILFLD & $\begin{array}{l}\text { Extra-heavy crude petroleum oil } \\
\text { fields }\end{array}$ & $\begin{array}{l}\text { Count of individual fields } \\
\text { included within the country } \\
\text { or petroleum province; data } \\
\text { withheld for less than one field }\end{array}$ & IHS IEPD & No \\
\hline XHC_GASCM_BCM & $\begin{array}{l}\text { Conventional cumulative produc- } \\
\text { tion of gas from extra-heavy } \\
\text { crude resources from oil fields, } \\
\text { in billion cubic meters }\end{array}$ & & IHS IEPD & No \\
\hline XHC_GASRPP_BCM & $\begin{array}{l}\text { Recoverable proven plus probable } \\
\text { resource total for gas from extra- } \\
\text { heavy crude resources from oil } \\
\text { fields, in billion cubic meters }\end{array}$ & & IHS IEPD & No \\
\hline XHC_CNDCM_BCM & $\begin{array}{l}\text { Conventional cumulative } \\
\text { production of condensate from } \\
\text { extra-heavy crude resources } \\
\text { from oil fields, in billion cubic } \\
\text { meters }\end{array}$ & & IHS IEPD & No \\
\hline
\end{tabular}


Table 20. User-defined attribute fields in the OG_COUNTRY and OG_PETRO_PROV data feature classes.—Continued

[NA, not applicable; PP, petroleum province]

\begin{tabular}{|c|c|c|c|c|}
\hline $\begin{array}{l}\text { Field name abbreviation in } \\
\text { LAC_Indust_Infra.gdb }\end{array}$ & Field name or description & Comment & Data source & $\begin{array}{l}\text { Attribute field } \\
\text { included in } \\
\text { geospatial } \\
\text { PDF map }\end{array}$ \\
\hline XHC_CNDRPP_BCM & $\begin{array}{l}\text { Recoverable proven plus probable } \\
\text { resource total for condensate } \\
\text { from extra-heavy crude } \\
\text { resources from oil fields, in } \\
\text { billion cubic meters }\end{array}$ & & IHS IEPD & No \\
\hline UNCONV_OILFLD & $\begin{array}{l}\text { Unconventional petroleum resource } \\
\text { oil fields }\end{array}$ & $\begin{array}{l}\text { Count of individual fields } \\
\text { included within the country } \\
\text { or petroleum province; data } \\
\text { withheld for less than one field }\end{array}$ & IHS IEPD & No \\
\hline UNCONV_OILCM_MCM & $\begin{array}{l}\text { Conventional cumulative produc- } \\
\text { tion of oil from unconventional } \\
\text { resources from oil fields, in } \\
\text { million cubic meters }\end{array}$ & $\begin{array}{l}\text { Unconventional resources include } \\
\text { coalbed methane, shale gas, } \\
\text { tight gas, shale oil, and tight oil }\end{array}$ & IHS IEPD & No \\
\hline UNCONV_OILRPP_MCM & $\begin{array}{l}\text { Recoverable proven plus prob- } \\
\text { able resource total for oil from } \\
\text { unconventional resources from } \\
\text { oil fields, in million cubic meters }\end{array}$ & $\begin{array}{l}\text { Unconventional resources include } \\
\text { coalbed methane, shale gas, } \\
\text { tight gas, shale oil, and tight oil }\end{array}$ & IHS IEPD & No \\
\hline UNCONV_GASCM_BCM & $\begin{array}{l}\text { Conventional cumulative produc- } \\
\text { tion of gas from unconventional } \\
\text { resources from oil fields, in } \\
\text { billion cubic meters }\end{array}$ & $\begin{array}{l}\text { Unconventional resources include } \\
\text { coalbed methane, shale gas, } \\
\text { tight gas, shale oil, and tight oil }\end{array}$ & IHS IEPD & No \\
\hline UNCONV_GASRPP_BCM & $\begin{array}{l}\text { Recoverable proven plus probable } \\
\text { resource total for gas from } \\
\text { unconventional resources from } \\
\text { oil fields, in billion cubic meters }\end{array}$ & $\begin{array}{l}\text { Unconventional resources include } \\
\text { coalbed methane, shale gas, } \\
\text { tight gas, shale oil, and tight oil }\end{array}$ & IHS IEPD & No \\
\hline UNCONV_CNDCM_BCM & $\begin{array}{l}\text { Conventional cumulative } \\
\text { production of condensate from } \\
\text { unconventional resources from } \\
\text { oil fields, in billion cubic meters }\end{array}$ & $\begin{array}{l}\text { Unconventional resources include } \\
\text { coalbed methane, shale gas, } \\
\text { tight gas, shale oil, and tight oil }\end{array}$ & IHS IEPD & No \\
\hline UNCONV_CNDRPP_BCM & $\begin{array}{l}\text { Recoverable proven plus probable } \\
\text { resource total for condensate } \\
\text { from unconventional resources } \\
\text { from oil fields, in billion cubic } \\
\text { meters }\end{array}$ & $\begin{array}{l}\text { Unconventional resources include } \\
\text { coalbed methane, shale gas, } \\
\text { tight gas, shale oil, and tight oil }\end{array}$ & IHS IEPD & No \\
\hline OO_MCM & $\begin{array}{l}\text { Oil from oil fields, used for undis- } \\
\text { covered, technically recoverable } \\
\text { conventional hydrocarbon } \\
\text { resources from oil fields, in } \\
\text { million cubic meters }\end{array}$ & & USGS & No \\
\hline GO_BCM & $\begin{array}{l}\text { Gas from oil fields, used for undis- } \\
\text { covered, technically recoverable } \\
\text { conventional hydrocarbon } \\
\text { resources from oil fields, in } \\
\text { billion cubic meters }\end{array}$ & & USGS & No \\
\hline NGLO_MCM & $\begin{array}{l}\text { Natural gas liquids from oil fields, } \\
\text { used for undiscovered, techni- } \\
\text { cally recoverable conventional } \\
\text { hydrocarbon resources from oil } \\
\text { fields, in million cubic meters }\end{array}$ & & USGS & No \\
\hline
\end{tabular}


Table 20. User-defined attribute fields in the OG_COUNTRY and OG_PETRO_PROV data feature classes._-Continued

[NA, not applicable; PP, petroleum province]

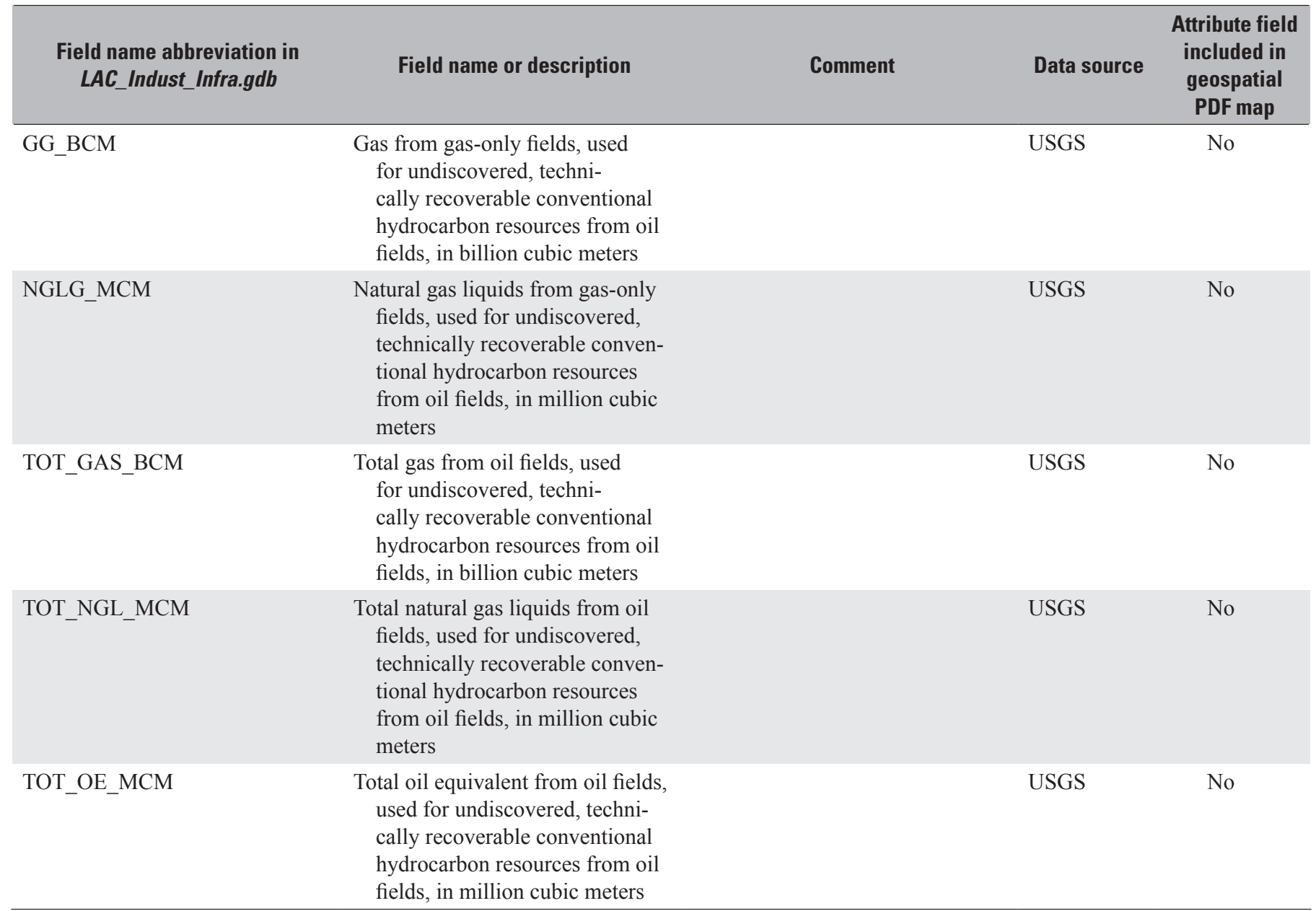

\section{IHS IEPD data as displayed on the geospatial PDF map}

For the geospatial PDF map, example map layers were drawn to show the rank and magnitude of the oil and gas production and resource data. These layers consist of (i) cumulative production of conventional oil by country, (ii) cumulative production of conventional oil by petroleum province, (iii) recoverable proven plus probable (RPP) hydrocarbon resources by country, and (iv) RPP by petroleum province. The layers are organized into two folders labelled "Cumulative Production" and "Recoverable Proven Plus Probable," with the individual layers including "by country" or "by petroleum province" in the layer name. Owing to file size limitations within the geospatial PDF, the entire OG_COUNTRY and OG_PETRO_PROV feature classes are not visually drawn within the map, but a user having access to Esri ArcGIS would be able to generate similar categorized and ranked maps, or use the tabular data to generate analyses in a similar fashion.

\section{Additional information and data tables for OG_COUNTRY and OG_PETRO_PROV}

Within this report, the $O_{-}$COUNTRY and OG_PETRO_ $P R O V$ feature classes were organized into a more readable format, to assist users not having access to the geodatabase data table. This was done to also show the data in a more specific format for the five hydrocarbon resource categories (four from IHS IEPD, one from USGS), as compared to the full data tables in the geodatabase that have over 50 data fields per feature class. For explanatory purposes, five data tables by country and five data tables by petroleum province were created to include in this report. Oil and gas production from unconventional sources includes shale oil, shale gas, coalbed methane, tight gas, and tight oil resources, whereas conventional excludes all of these categories.

Cumulative production is defined at the oil or gas field level and is cumulative from the time the field began production; thus, for the country and petroleum province 
level, production start dates vary based on the constituent fields within that geographic area. The ending time period for the most recent report of cumulative production was either 2014 or 2015 for 95 percent of the individual fields within this dataset. A gas field is defined as a field having a gas-to-oil ratio (GOR) greater than or equal to 20,000 cubic feet of gas at standard conditions to one stock barrel of oil, using industryaccepted conventional American oil field units. ${ }^{12}$ Historically,

\footnotetext{
${ }^{12}$ In this report, the term "standard conditions" refers to standard temperature and pressure and is defined by the Society of Petroleum Engineers as 14.7 pounds per square inch and $60^{\circ} \mathrm{F}$ when gas volumes are reported in industry-accepted conventional American oil field units. For the metric system, standard conditions are defined as $15^{\circ} \mathrm{C}$ and 1 atmosphere (Society of Petroleum Engineers, 2001, p. 31).
}

non-associated gas in gas-only fields was considered less economical for recovery, so associated gas production is greater from oil fields. Data may be withheld for individual geographic areas (countries or petroleum provinces) to conceal and protect proprietary data.

Table 21 shows cumulative production data and RPP resources for conventional hydrocarbon resources from oil fields by country, and table 22 shows the same by petroleum province. These two tables show example data from the IHS IEPD portion of the database. Table 23 and table 24 show the mean volumes of undiscovered, technically recoverable conventional hydrocarbon resources from oil fields by country and by petroleum province, respectively, as examples of the

Table 21. Cumulative production and recoverable proven plus probable resources of conventional hydrocarbon resources from oil fields, by country within Latin America and the Caribbean, from the OG_COUNTRY feature class.

[Data derived from IHS International Exploration and Production Database; used with permission from IHS Global, Inc. (IHS Global Inc., 2016). Excludes extra-heavy crude and unconventional resources (coalbed methane, shale gas, tight gas, shale oil, and tight oil). Data for oil and condensate in million cubic meters (MCM); data for gas in billion cubic meters (BCM). LT1, less than one unit; NA, not available; RPP, recoverable proven plus probable resources; $\mathrm{W}$, withheld to conceal proprietary data. Data are rounded to no more than three significant digits; may not add to totals shown. Data are unrounded for total of number of fields]

\begin{tabular}{|c|c|c|c|c|c|c|c|}
\hline Country & $\begin{array}{l}\text { Total number } \\
\text { of oil fields }\end{array}$ & $\begin{array}{l}\text { Cumulative } \\
\text { oil production } \\
\text { (MCM) }\end{array}$ & $\begin{array}{l}\text { Oil RPP } \\
\text { (MCM) }\end{array}$ & $\begin{array}{l}\text { Cumulative } \\
\text { gas production } \\
\text { (BCM) }\end{array}$ & $\begin{array}{c}\text { Gas RPP } \\
\text { (BCM) }\end{array}$ & $\begin{array}{c}\text { Cumulative } \\
\text { condensate } \\
\text { production } \\
\text { (MCM) }\end{array}$ & $\begin{array}{l}\text { Condensate } \\
\text { RPP } \\
\text { (MCM) }\end{array}$ \\
\hline Argentina & 825 & 1,490 & 1,960 & 372 & 503 & 3 & 6 \\
\hline Barbados & 16 & 2 & 3 & LT1 & 1 & LT1 & LT1 \\
\hline Belize & 4 & 1 & 4 & NA & LT1 & NA & NA \\
\hline Bolivia & 39 & 45 & 54 & 27 & 47 & 3 & 5 \\
\hline Brazil & 827 & 2,380 & 14,100 & 386 & 3,680 & LT1 & 72 \\
\hline Chile & 100 & 38 & 50 & 36 & 54 & NA & LT1 \\
\hline Colombia & 518 & 1,380 & 1,920 & 176 & 296 & NA & 9 \\
\hline Costa Rica & 1 & NA & NA & NA & NA & NA & NA \\
\hline Cuba & 35 & 57 & 96 & 1 & 16 & NA & NA \\
\hline Dominican Republic & 2 & NA & LT1 & NA & NA & NA & NA \\
\hline Ecuador & 186 & 901 & 1,490 & 33 & 72 & NA & NA \\
\hline $\begin{array}{l}\text { Falkland Islands / } \\
\text { Islas Malvinas } \\
\text { (United Kingdom) }\end{array}$ & 4 & NA & 72 & NA & 13 & NA & LT1 \\
\hline French Guiana & 1 & NA & NA & NA & NA & NA & NA \\
\hline Guatemala & 14 & 25 & 37 & NA & 1 & NA & NA \\
\hline Guyana & 2 & NA & 32 & NA & 3 & NA & NA \\
\hline Mexico & 459 & 6,790 & 9,340 & 1,500 & 2,200 & LT1 & LT1 \\
\hline Nicaragua & 4 & NA & LT1 & NA & LT1 & NA & NA \\
\hline Paraguay & NA & NA & NA & NA & NA & NA & NA \\
\hline Peru & 118 & 430 & 740 & 52 & 158 & NA & LT1 \\
\hline Suriname & 4 & 17 & 20 & NA & LT1 & NA & NA \\
\hline Trinidad and Tobago & 74 & 582 & 665 & 140 & 236 & NA & LT1 \\
\hline Venezuela & 375 & 10,300 & 16,000 & 2,380 & 4,940 & 52 & 367 \\
\hline Total & 3,608 & 24,500 & 46,600 & 5,100 & 12,200 & 58 & 461 \\
\hline
\end{tabular}


Table 22. Cumulative production and recoverable proven plus probable resources of conventional hydrocarbon resources from oil fields, by petroleum province within Latin America and the Caribbean, from the OG_PETRO_PROV feature class.

[Data derived from IHS International Exploration and Production Database; used with permission from IHS Global, Inc. (IHS Global Inc., 2016). Excludes extra-heavy crude and unconventional resources (coalbed methane, shale gas, tight gas, shale oil, and tight oil). Data for oil and condensate in million cubic meters (MCM); data for gas in billion cubic meters (BCM). LT1, less than one unit; NA, not available; RPP, recoverable proven plus probable resources; W, withheld to conceal proprietary data. Data are rounded to no more than three significant digits; may not add to totals shown. Data are unrounded for total of number of fields]

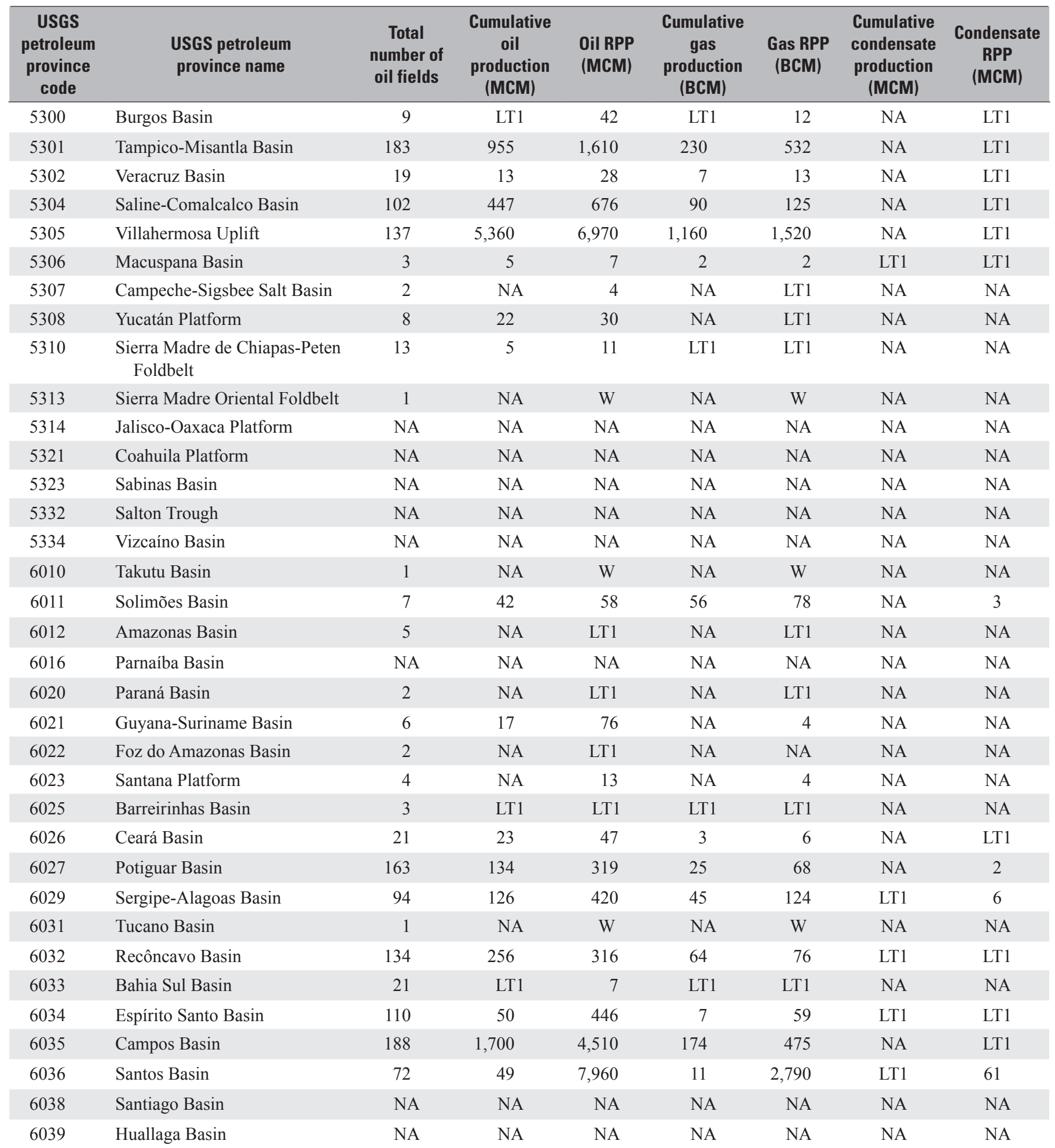


Table 22. Cumulative production and recoverable proven plus probable resources of conventional hydrocarbon resources from oil fields, by petroleum province within Latin America and the Caribbean, from the OG_PETRO_PROV feature class._Continued

[Data derived from IHS International Exploration and Production Database; used with permission from IHS Global, Inc. (IHS Global Inc., 2016). Excludes extra-heavy crude and unconventional resources (coalbed methane, shale gas, tight gas, shale oil, and tight oil). Data for oil and condensate in million cubic meters (MCM); data for gas in billion cubic meters (BCM). LT1, less than one unit; NA, not available; RPP, recoverable proven plus probable resources; $\mathrm{W}$, withheld to conceal proprietary data. Data are rounded to no more than three significant digits; may not add to totals shown. Data are unrounded for total of number of fields]

\begin{tabular}{|c|c|c|c|c|c|c|c|c|}
\hline $\begin{array}{c}\text { USGS } \\
\text { petroleum } \\
\text { province } \\
\text { code }\end{array}$ & $\begin{array}{l}\text { USGS petroleum } \\
\text { province name }\end{array}$ & $\begin{array}{c}\text { Total } \\
\text { number of } \\
\text { oil fields }\end{array}$ & $\begin{array}{l}\text { Cumulative } \\
\text { oil } \\
\text { production } \\
\text { (MCM) }\end{array}$ & $\begin{array}{l}\text { Oil RPP } \\
\text { (MCM) }\end{array}$ & $\begin{array}{l}\text { Cumulative } \\
\text { gas } \\
\text { production } \\
\text { (BCM) }\end{array}$ & $\begin{array}{l}\text { Gas RPP } \\
\text { (BCM) }\end{array}$ & $\begin{array}{c}\text { Cumulative } \\
\text { condensate } \\
\text { production } \\
\text { (MCM) }\end{array}$ & $\begin{array}{c}\text { Condensate } \\
\text { RPP } \\
\text { (MCM) }\end{array}$ \\
\hline 6040 & Ucayali Basin & 9 & 5 & 11 & NA & LT1 & NA & NA \\
\hline 6041 & $\begin{array}{l}\text { Putumayo-Oriente-Maranon } \\
\text { Basin }\end{array}$ & 267 & 1,120 & 1,870 & 45 & 91 & NA & NA \\
\hline 6043 & Madre dos Dios Basin & 1 & NA & W & NA & W & NA & NA \\
\hline 6044 & Beni Basin & 1 & NA & W & NA & W & NA & NA \\
\hline 6045 & Santa Cruz-Tarija Basin & 49 & 49 & 59 & 28 & 48 & 3 & 5 \\
\hline 6046 & Oran-Olmedo Basin & 35 & 22 & 29 & 5 & 6 & NA & NA \\
\hline 6051 & Cuyo Basin & 46 & 221 & 258 & 9 & 11 & NA & NA \\
\hline 6055 & Neuquén Basin & 419 & 522 & 636 & 200 & 252 & 2 & 3 \\
\hline 6058 & San Jorge Basin & 217 & 655 & 951 & 114 & 168 & NA & LT1 \\
\hline 6059 & Magallanes Basin & 194 & 104 & 129 & 80 & 120 & 1 & 2 \\
\hline 6060 & Falklands Plateau & 4 & NA & 72 & NA & 13 & NA & LT1 \\
\hline 6063 & Malvinas Basin & 2 & NA & LT1 & NA & LT1 & NA & NA \\
\hline 6065 & Altiplano Basin & 1 & $\mathrm{~W}$ & $\mathrm{~W}$ & NA & NA & NA & NA \\
\hline 6069 & Temuco Basin & NA & NA & NA & NA & NA & NA & NA \\
\hline 6074 & Central Chile Forearc Basin & NA & NA & NA & NA & NA & NA & NA \\
\hline 6080 & Sechura Basin & NA & NA & NA & NA & NA & NA & NA \\
\hline 6081 & Talara Basin & 58 & 256 & 393 & 48 & 143 & NA & LT1 \\
\hline 6083 & Progreso Basin & 16 & 23 & 48 & 5 & 13 & NA & LT1 \\
\hline 6087 & Choco Pacific Basin & 2 & NA & LT1 & NA & LT1 & NA & NA \\
\hline 6089 & Upper Magdalena Valley Basin & 57 & 139 & 174 & 11 & 37 & NA & LT1 \\
\hline 6090 & $\begin{array}{l}\text { Middle Magdalena Valley } \\
\text { Basin }\end{array}$ & 100 & 406 & 528 & 93 & 110 & NA & LT1 \\
\hline 6091 & Lower Magdalena Valley Basin & 9 & 11 & 12 & 7 & 7 & NA & NA \\
\hline 6093 & $\begin{array}{l}\text { Perijá-Venezuela-Coastal } \\
\text { Ranges }\end{array}$ & 1 & $\mathrm{~W}$ & W & NA & NA & NA & NA \\
\hline 6094 & Cesar Basin & 1 & NA & W & NA & W & NA & NA \\
\hline 6095 & Guarija Basin & 1 & NA & W & NA & W & NA & NA \\
\hline 6096 & Llanos Basin & 295 & 793 & 1,180 & 38 & 110 & NA & 8 \\
\hline 6097 & Barinas-Apure Basin & 16 & 135 & 372 & 4 & 5 & NA & LT1 \\
\hline 6098 & East Venezuela Basin & 347 & 3,680 & 5,940 & 1,400 & 3,180 & 33 & 293 \\
\hline 6099 & Maracaibo Basin & 71 & 7,020 & 10,200 & 1,120 & 1,970 & 19 & 74 \\
\hline 6100 & Falcon Basin & 16 & 19 & 32 & 3 & 14 & NA & LT1 \\
\hline 6102 & Cariaco Basin & 4 & NA & 14 & NA & 11 & NA & LT1 \\
\hline 6103 & Tobago Trough & NA & NA & NA & NA & NA & NA & NA \\
\hline 6104 & $\begin{array}{l}\text { South Caribbean Deformed } \\
\text { Belt }\end{array}$ & NA & NA & NA & NA & NA & NA & NA \\
\hline
\end{tabular}


Table 22. Cumulative production and recoverable proven plus probable resources of conventional hydrocarbon resources from oil fields, by petroleum province within Latin America and the Caribbean, from the OG_PETRO_PROV feature class._-Continued

[Data derived from IHS International Exploration and Production Database; used with permission from IHS Global, Inc. (IHS Global Inc., 2016). Excludes extra-heavy crude and unconventional resources (coalbed methane, shale gas, tight gas, shale oil, and tight oil). Data for oil and condensate in million cubic meters (MCM); data for gas in billion cubic meters (BCM). LT1, less than one unit; NA, not available; RPP, recoverable proven plus probable resources; W, withheld to conceal proprietary data. Data are rounded to no more than three significant digits; may not add to totals shown. Data are unrounded for total of number of fields]

\begin{tabular}{|c|c|c|c|c|c|c|c|c|}
\hline $\begin{array}{l}\text { USGS } \\
\text { petroleum } \\
\text { province } \\
\text { code }\end{array}$ & $\begin{array}{l}\text { USGS petroleum } \\
\text { province name }\end{array}$ & $\begin{array}{c}\text { Total } \\
\text { number of } \\
\text { oil fields }\end{array}$ & $\begin{array}{c}\text { Cumulative } \\
\text { oil } \\
\text { production } \\
\text { (MCM) }\end{array}$ & $\begin{array}{l}\text { Oil RPP } \\
\text { (MCM) }\end{array}$ & $\begin{array}{c}\text { Cumulative } \\
\text { gas } \\
\text { production } \\
\text { (BCM) }\end{array}$ & $\begin{array}{c}\text { Gas RPP } \\
\text { (BCM) }\end{array}$ & $\begin{array}{c}\text { Cumulative } \\
\text { condensate } \\
\text { production } \\
\text { (MCM) }\end{array}$ & $\begin{array}{c}\text { Condensate } \\
\text { RPP } \\
\text { (MCM) }\end{array}$ \\
\hline 6106 & West-Central Cordillera & 2 & NA & LT1 & NA & LT1 & NA & NA \\
\hline 6107 & Lesser Antilles Deformed Belt & 16 & 2 & 3 & LT1 & 1 & LT1 & LT1 \\
\hline 6114 & North Nicaraguan Rise & 3 & NA & LT1 & NA & LT1 & NA & NA \\
\hline \multicolumn{2}{|l|}{ Total } & 3,608 & 24,400 & 46,600 & 5,090 & 12,200 & 58 & 461 \\
\hline
\end{tabular}

Table 23. Total mean volumes of undiscovered, technically recoverable conventional hydrocarbon resources from oil fields, by country within Latin America and the Caribbean, from the OG_COUNTRY feature class.

[Data derived from IHS International Exploration and Production Database; used with permission from IHS Global, Inc. (IHS Global Inc., 2016). Excludes extra-heavy crude and unconventional resources (coalbed methane, shale gas, tight gas, shale oil, and tight oil). Data for oil, natural gas liquids, and total oil equivalent in million cubic meters (MCM); data for gas in billion cubic meters (BCM). LT1, less than one unit. Data are rounded to no more than three significant digits; may not add to totals shown. Data are unrounded for total of number of fields]

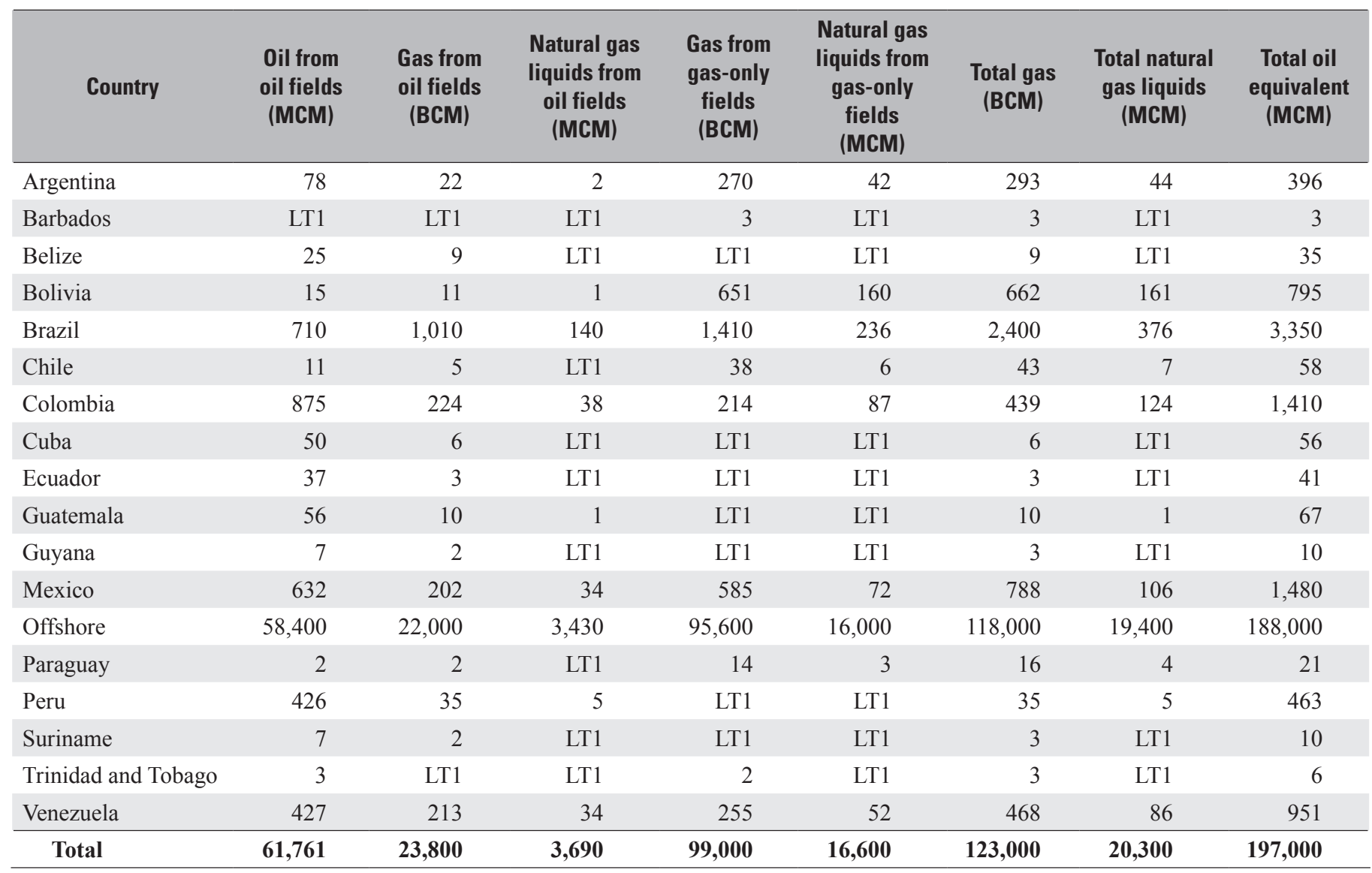


Table 24. Total mean volumes of undiscovered, technically recoverable conventional hydrocarbon resources from oil fields, by petroleum province within Latin America and the Caribbean, from the OG_PETRO_PROV feature class.

[Data derived from IHS International Exploration and Production Database; used with permission from IHS Global, Inc. (IHS Global Inc., 2016). Excludes extra-heavy crude and unconventional resources (coalbed methane, shale gas, tight gas, shale oil, and tight oil). Data for oil, natural gas liquids, and total oil equivalent in million cubic meters (MCM); data for gas in billion cubic meters (BCM). LT1, less than one unit; W, data withheld to conceal proprietary data. Data are rounded to no more than three significant digits; may not add to totals shown. Data are unrounded for grand total of number of fields]

\begin{tabular}{|c|c|c|c|c|c|c|c|c|c|}
\hline $\begin{array}{l}\text { USGS } \\
\text { petroleum } \\
\text { province } \\
\text { code }\end{array}$ & $\begin{array}{l}\text { USGS petroleum } \\
\text { province name }\end{array}$ & $\begin{array}{l}\text { Oil from oil } \\
\text { fields } \\
\text { (MCM) }\end{array}$ & $\begin{array}{l}\text { Gas from } \\
\text { oil fields } \\
\text { (BCM) }\end{array}$ & $\begin{array}{l}\text { Natural gas } \\
\text { liquids from } \\
\text { oil fields } \\
\text { (MCM) }\end{array}$ & $\begin{array}{c}\text { Gas from } \\
\text { gas-only } \\
\text { fields } \\
\text { (BCM) }\end{array}$ & $\begin{array}{c}\text { Natural gas } \\
\text { liquids from } \\
\text { gas-only fields } \\
\text { (MCM) }\end{array}$ & $\begin{array}{l}\text { Total gas } \\
\text { (BCM) }\end{array}$ & $\begin{array}{l}\text { Total natural } \\
\text { gas liquids } \\
\text { (MCM) }\end{array}$ & $\begin{array}{l}\text { Total oil } \\
\text { equivalent } \\
\text { (MCM) }\end{array}$ \\
\hline 5300 & Burgos Basin & 980 & 209 & 24 & 365 & 59 & 575 & 82 & 1,600 \\
\hline 5301 & $\begin{array}{l}\text { Tampico-Misantla } \\
\text { Basin }\end{array}$ & 866 & 286 & 49 & 402 & 59 & 688 & 108 & 1,600 \\
\hline 5302 & Veracruz Basin & 15 & 4 & LT1 & 246 & 7 & 250 & 7 & 256 \\
\hline 5303 & Tuxtla Uplift & 4 & LT1 & LT1 & 26 & LT1 & 27 & LT1 & 30 \\
\hline 5304 & $\begin{array}{l}\text { Saline-Comalcalco } \\
\text { Basin }\end{array}$ & 181 & 59 & 25 & 21 & LT1 & 80 & 25 & 281 \\
\hline 5305 & Villahermosa Uplift & 227 & 130 & 8 & 92 & 11 & 222 & 19 & 453 \\
\hline 5306 & Macuspana Basin & 4 & 4 & LT1 & 12 & LT1 & 16 & LT1 & 19 \\
\hline 5307 & $\begin{array}{l}\text { Campeche-Sigsbee } \\
\text { Salt Basin }\end{array}$ & 455 & 269 & 10 & 122 & 14 & 390 & 24 & 845 \\
\hline 5308 & Yucatán Platform & 205 & 84 & 5 & LT1 & LT1 & 84 & 5 & 289 \\
\hline 5310 & $\begin{array}{l}\text { Sierra Madre de } \\
\text { Chiapas-Peten } \\
\text { Foldbelt }\end{array}$ & 148 & 21 & 4 & LT1 & LT1 & 21 & 4 & 172 \\
\hline 6006 & Andean Province & LT1 & LT1 & LT1 & 28 & 7 & 29 & 7 & 34 \\
\hline 6011 & Solimões Basin & 91 & 132 & 18 & 523 & 81 & 655 & 99 & 804 \\
\hline 6012 & Amazonas Basin & 59 & 85 & 12 & 188 & 29 & 273 & 41 & 356 \\
\hline 6016 & Parnaíba Basin & 473 & 685 & 95 & 503 & 78 & 1,200 & 173 & 1,760 \\
\hline 6020 & Paraná Basin & 68 & 99 & 14 & 187 & 46 & 286 & 60 & 396 \\
\hline 6021 & $\begin{array}{l}\text { Guyana-Suriname } \\
\text { Basin }\end{array}$ & 2,200 & 606 & 92 & 489 & 97 & 1,100 & 190 & 3,400 \\
\hline 6022 & $\begin{array}{l}\text { Foz do Amazonas } \\
\text { Basin }\end{array}$ & 62 & 17 & 3 & 545 & 154 & 563 & 157 & 746 \\
\hline 6023 & Santana Platform & 26 & 7 & 1 & 230 & 65 & 237 & 66 & 314 \\
\hline 6029 & $\begin{array}{l}\text { Sergipe-Alagoas } \\
\text { Basin }\end{array}$ & 316 & 126 & 43 & 110 & 38 & 236 & 81 & 617 \\
\hline 6034 & Espírito Santo Basin & 303 & 114 & 12 & 419 & 85 & 533 & 97 & 899 \\
\hline 6035 & Campos Basin & 2,300 & 781 & 132 & 150 & 27 & 931 & 158 & 3,370 \\
\hline 6036 & Santos Basin & 9,500 & 4,200 & 685 & 1,760 & 295 & 6,000 & 980 & 16,000 \\
\hline 6037 & Pelotas Basin & 124 & 51 & 18 & 533 & 65 & 584 & 83 & 754 \\
\hline 6041 & $\begin{array}{c}\text { Putumayo-Oriente- } \\
\text { Maranon Basin }\end{array}$ & 747 & 61 & 9 & LT1 & LT1 & 61 & 9 & 813 \\
\hline 6044 & Beni Basin & LT1 & LT1 & LT1 & 21 & 5 & 21 & 5 & 26 \\
\hline 6045 & $\begin{array}{l}\text { Santa Cruz-Tarija } \\
\text { Basin }\end{array}$ & 18 & 13 & 2 & 680 & 167 & 693 & 168 & 834 \\
\hline 6046 & Oran-Olmedo Basin & LT1 & LT1 & LT1 & 8 & 2 & 8 & 2 & 9 \\
\hline 6054 & $\begin{array}{l}\text { Salado-Punta del } \\
\text { Este Basin }\end{array}$ & 107 & 44 & 15 & 214 & 26 & 258 & 41 & 389 \\
\hline 6055 & Neuquén Basin & 53 & 14 & 2 & 107 & 9 & 121 & 11 & 177 \\
\hline
\end{tabular}


Table 24. Total mean volumes of undiscovered, technically recoverable conventional hydrocarbon resources from oil fields, by petroleum province within Latin America and the Caribbean, from the OG_PETRO_PROV feature class.—Continued

[Data derived from IHS International Exploration and Production Database; used with permission from IHS Global, Inc. (IHS Global Inc., 2016). Excludes extra-heavy crude and unconventional resources (coalbed methane, shale gas, tight gas, shale oil, and tight oil). Data for oil, natural gas liquids, and total oil equivalent in million cubic meters (MCM); data for gas in billion cubic meters (BCM). LT1, less than one unit; W, data withheld to conceal proprietary data. Data are rounded to no more than three significant digits; may not add to totals shown. Data are unrounded for grand total of number of fields]

\begin{tabular}{|c|c|c|c|c|c|c|c|c|c|}
\hline $\begin{array}{l}\text { USGS } \\
\text { petroleum } \\
\text { province } \\
\text { code }\end{array}$ & $\begin{array}{l}\text { USGS petroleum } \\
\text { province name }\end{array}$ & $\begin{array}{l}\text { Oil from oil } \\
\text { fields } \\
\text { (MCM) }\end{array}$ & $\begin{array}{c}\text { Gas from } \\
\text { oil fields } \\
\text { (BCM) }\end{array}$ & $\begin{array}{l}\text { Natural gas } \\
\text { liquids from } \\
\text { oil fields } \\
\text { (MCM) }\end{array}$ & $\begin{array}{c}\text { Gas from } \\
\text { gas-only } \\
\text { fields } \\
\text { (BCM) }\end{array}$ & $\begin{array}{l}\text { Natural gas } \\
\text { liquids from } \\
\text { gas-only fields } \\
\text { (MCM) }\end{array}$ & $\begin{array}{l}\text { Total gas } \\
\text { (BCM) }\end{array}$ & $\begin{array}{l}\text { Total natural } \\
\text { gas liquids } \\
\text { (MCM) }\end{array}$ & $\begin{array}{l}\text { Total oil } \\
\text { equivalent } \\
\text { (MCM) }\end{array}$ \\
\hline 6058 & San Jorge Basin & 11 & 1 & LT1 & 6 & LT1 & 7 & LT1 & 18 \\
\hline 6059 & Magallanes Basin & 33 & 14 & LT1 & 167 & 28 & 181 & 29 & 231 \\
\hline 6060 & Falklands Plateau & 843 & 342 & 25 & 1,100 & 163 & 1,440 & 187 & 2,380 \\
\hline 6063 & Malvinas Basin & 22 & 9 & LT1 & 163 & 27 & 173 & 28 & 211 \\
\hline 6089 & $\begin{array}{l}\text { Upper Magdalena } \\
\text { Valley Basin }\end{array}$ & 62 & 16 & 2 & 14 & 1 & 30 & 3 & 93 \\
\hline 6090 & $\begin{array}{l}\text { Middle Magdalena } \\
\text { Valley Basin }\end{array}$ & 85 & 27 & 2 & 19 & 2 & 46 & 4 & 131 \\
\hline 6096 & Llanos Basin & 424 & 148 & 28 & 90 & 54 & 238 & 82 & 728 \\
\hline 6097 & Barinas-Apure Basin & 88 & 1 & LT1 & 25 & 1 & 26 & 2 & 114 \\
\hline 6098 & East Venezuela Basin & 537 & 323 & 40 & 820 & 129 & 1,140 & 168 & 1,780 \\
\hline 6099 & Maracaibo Basin & 148 & 55 & 13 & 169 & 27 & 225 & 40 & 398 \\
\hline 6103 & Tobago Trough & LT1 & LT1 & LT1 & 446 & 10 & 446 & 10 & 427 \\
\hline 6107 & $\begin{array}{l}\text { Lesser Antilles } \\
\text { Deformed Belt }\end{array}$ & 24 & 9 & 2 & 413 & 55 & 422 & 57 & 476 \\
\hline 6117 & $\begin{array}{l}\text { Greater Antilles } \\
\text { Deformed Belt }\end{array}$ & 894 & 265 & 132 & 109 & 17 & 375 & 150 & 1,400 \\
\hline
\end{tabular}

USGS data that comprise the last fields in the OG_COUNTRY and $O G \_P E T R O \_P R O V$ feature classes.

Additional tables in appendix 1 (data tables 1-1 through 1-7) follow this layout, for both country and petroleum province data, for the other hydrocarbon resource categories from IHS IEPD: (i) conventional hydrocarbon production and RPP resources for gas-only fields, (ii) extra-heavy crude resources from oil fields, and (iii) unconventional resources.

Venezuela leads the region for cumulative conventional oil production from oil fields, with over 10 billion cubic meters (BCM) produced, followed by Mexico (6.8 BCM), Brazil (2.4 BCM), Argentina (1.5 BCM), and Colombia (1.4 BCM). This order is nearly identical for recoverable proven plus probable conventional oil resources, with Venezuela containing over $16 \mathrm{BCM}$ of resources, followed by Brazil (14 BCM), Mexico (9 BCM), Argentina (2 BCM), and Colombia (1.9 BCM).
As shown in table 22, the Maracaibo Basin in Venezuela, which includes Lake Maracaibo, ranked first for cumulative conventional oil production by petroleum province, with over 7 BCM produced since production began. The Villahermosa Uplift, which includes producing areas near Paraíso, Tabasco State, Mexico, was second, with 5.4 BCM produced, followed by the East Venezuela Basin, which includes the Orinoco Oil Belt, with 3.7 BCM. The fourth ranked petroleum province was the Campos Basin off the coast of Rio de Janeiro State in Brazil, with approximately $1.7 \mathrm{BCM}$ produced. Similar to the country-level data, these petroleum provinces are also among the top five for recoverable proven plus probable conventional oil resources: the Maracaibo Basin with 10.2 BCM of RPP resources, the Santos Basin offshore of the States of Rio de Janeiro and São Paulo with almost 8 BCM, the Villahermosa Uplift with almost 7 BCM, the East Venezuela Basin with almost $6 \mathrm{BCM}$, and the Campos Basin with 4.5 BCM. The 
Santos Basin ranked 22d for cumulative conventional oil production but has been the site of intensive oil and gas exploration owing to its significant resources (Queiroz Galvão, 2016).

The undiscovered, technically recoverable conventional oil and gas resources data from the USGS 2012 world assessment (U.S. Geological Survey World Conventional Resources Assessment Team, 2013), as stated above, are very similar to the IHS IEPD data, although they employ different terminology. By country, the greatest total oil equivalent (TOE) for undiscovered, technically recoverable resources occurs in offshore areas that were not correlated to any specific country, at almost 188 BCM (table 23). Undiscovered, technically recoverable conventional offshore oil-only resources accounted for $58 \mathrm{BCM}$, or about 30 percent of the TOE for offshore areas. Onshore areas of Brazil accounted for the second-leading area for undiscovered resources, with about 3.4 BCM of TOE present, followed by onshore areas of Mexico (about 1.5 BCM) and Colombia (1.4 BCM).

As shown in table 24, by petroleum province, the greatest total oil equivalent (TOE) for undiscovered, technically recoverable resources occurs in the Santos Basin, at 16 BCM, followed by the Guyana-Suriname Basin offshore of the coasts of French Guiana, Guyana, and Suriname at 3.4 BCM; then the Campos Basin at slightly less than 3.4 BCM, the Falklands Plateau surrounding the Falkland Islands (an overseas territory of the United Kingdom, also known as Islas Malvinas) at 2.4 BCM, and the East Venezuela Basin at 1.8 BCM. The significant potential for all of these areas to contain additional hydrocarbon resources has been well documented throughtout industry literature, with considerable investment made by domestic and foreign companies looking to continue to explore and discover potentially economically exploitable resources, including those in deepwater and super-deepwater conditions.

\section{Transportation infrastructure- E_TRANSPOR_INFRA feature dataset}

The feature dataset E_TRANSPOR_INFRA contains one vector point feature class for mineral commodity exporting ports and one vector polyline feature class for railroads.

\section{Railroads-RAIL feature class}

The RAIL feature class originates from the 1992 version of the Digital Chart of the World (DCW), produced by the U.S. Defense Mapping Agency, which is now the National Geospatial-Intelligence Agency (NGA) (National GeospatialIntelligence Agency [formerly U.S. National Imagery and Mapping Agency], 1992). It is included for visual spatial reference and does not contain attribute information. While almost three decades old, the DCW is still one of the best generalized representations of approximate coverage of railroads worldwide. Some countries, notably Brazil, may have built railroads in the subsequent intervening time period; however, a rail-by-rail analysis and digitization effort was not possible for this project. Approximately $150,000 \mathrm{~km}$ of rail polylines are included in this feature class.

Rail ownership and operations within several countries have had periods of privatization and nationalization over the second half of the 20th century and into the 21st century. Brazil, for example, had a state-owned rail system that was nationalized in 1957 into the Rede Ferroviária Federal, S.A. (RFFSA) and operated under government control until 1999. At that time the system's assets were liquidated and leased to the following private companies for a 30 -year period, with the possibility of renewal for an additional 30-year period: Northeastern Railway Co. (CFN), Atlantic Central Railroad (FCA), MRS Logística S.A., Ferrovia Bandeirantes (Ferroban), Ferrovia Novoeste S.A., Latin America and Logistics (ALL), and Ferrovia Teresa Cristina S.A. (Rede Ferroviária Federal, S.A., 2007; Ministério dos Transportes, Portos e Aviação Civil, 2014). Similarly in Argentina, Ferrocarriles Argentinos S.A. (FA) was a state-owned company formed in 1948 which operated both passenger and freight services. In 1993, privatization of FA occurred, with seven companies taking ownership of freight services throughout the country. In 2015, the railways were re-nationalized under government control (Daily Ambito Financiero, 2015). Comparing these data from the DCW against Google Earth ${ }^{\mathrm{TM}}$ satellite imagery shows a rough approximation to on-the-ground paths of railroads, though some rail segments may have poorer locational accuracy than others and be farther off-course. However, at the regional scale, a visual comparison of the generalized rail paths to the mineral facility and other data feature classes shows a tight correlation between the locations of mines and mineral processing facilities and their degree of connectedness to the transportation network.

\section{Mineral commodity exporting ports- PORTS_LAC feature class}

The primary objective of constructing a ports feature class was to identify the maritime ports that export a significant contribution to the global supply of a subset of major primary mineral commodities that impact the global economy (table 25). The feature class comprises ports by name and location, their ownership or operating authority, primary mineral commodities exported, specific form of the mineral commodity, estimated annual export tonnage (estimated as the average for the years 2010-12), sources of the commodity (mine, smelter, or refinery, if known), and the destination country or countries of exports. This feature class includes 74 unique ports and 46 mineral commodities or commodity groupings, with a total record count of 230 data entries. Some mineral commodity groupings are shown by the primary metal in the "COMM_EXPD" (or "commodity exported") field, such as copper, with more specific forms of products listed in the "FORM_COMM" (or "form of commodity") field. Examples of a more specific form of copper exported include: anode copper, cathode copper, concentrates, ores and concentrates, refined metal, and wire. The majority of metals, such as 
Table 25. Description of user-defined attribute fields in the mineral commodity exporting ports feature class PORTS_LAC.

[ID, identification; GENC, Geopolitical Entities, Names, and Codes]

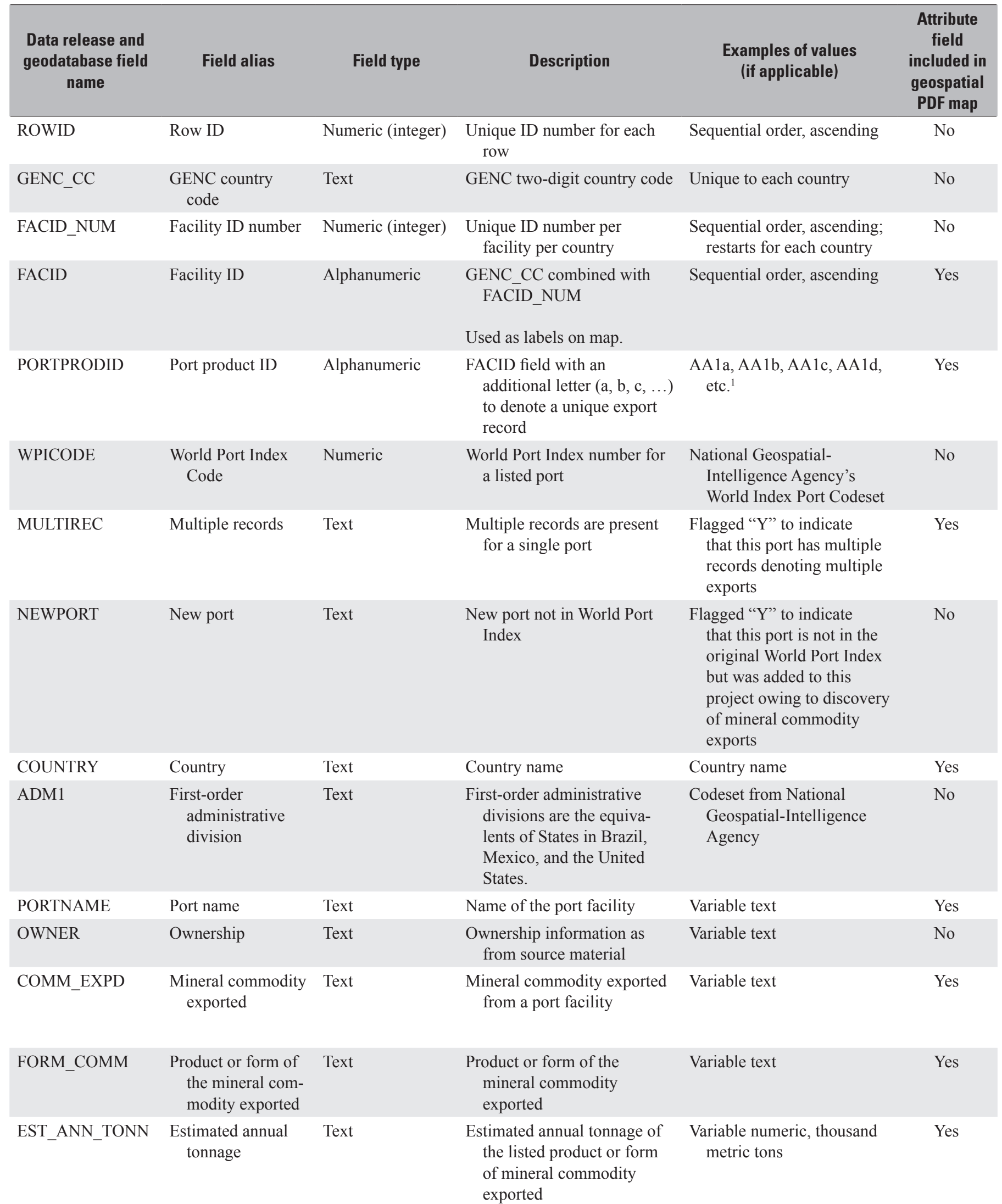


Table 25. Description of user-defined attribute fields in the mineral commodity exporting ports feature class PORTS_LAC.—Continued [ID, identification; GENC, Geopolitical Entities, Names, and Codes]

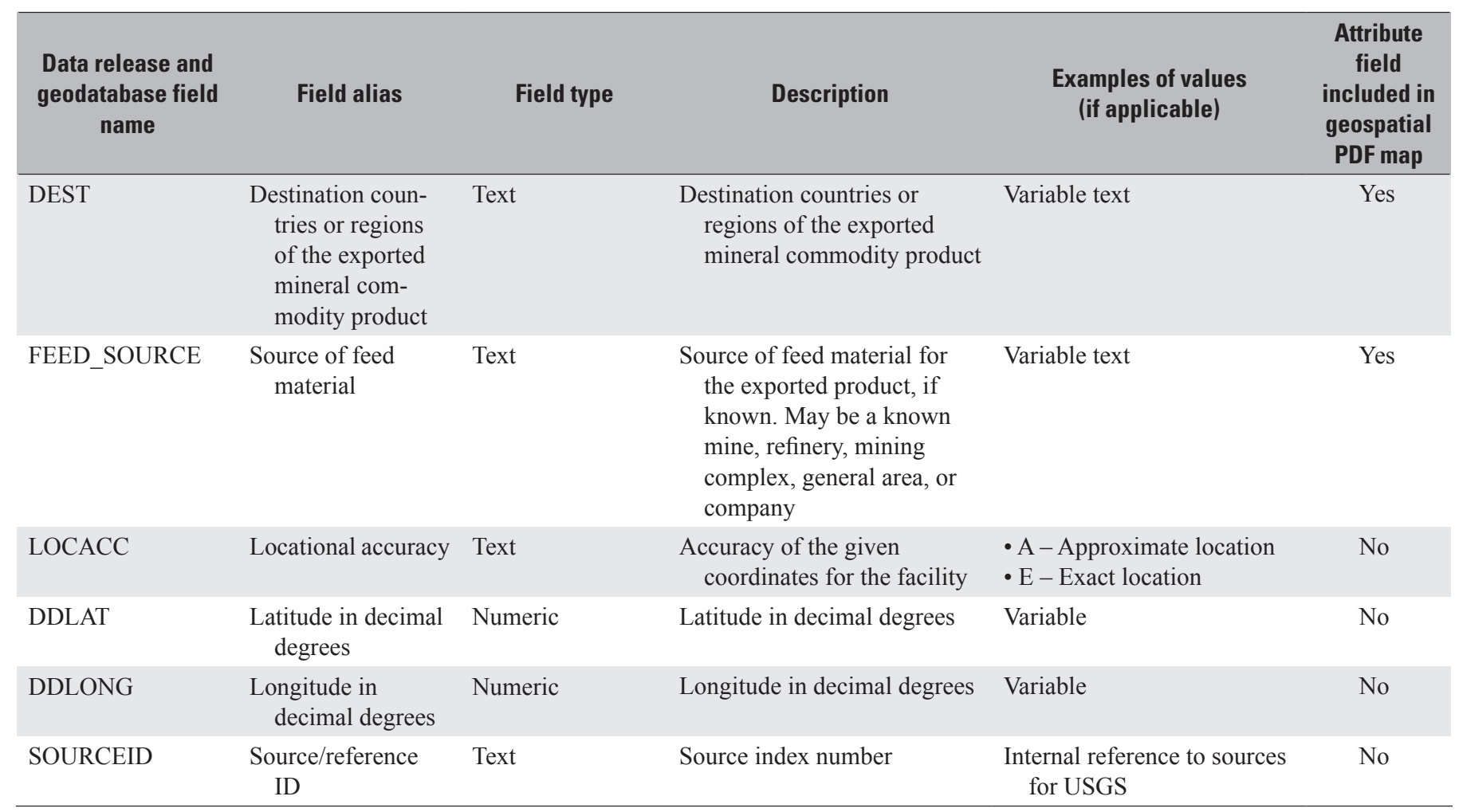

${ }^{1}$ For example, the feature class shows the FACID, or facility identification number, CL27 for the port of Mejillones, Chile. Mineral commodity products exported include copper cathodes (CL27a), silver-zinc concentrates (CL27b), lead-silver concentrates (CL27c), copper concentrates (CL27d), and molybdenum as contained in copper concentrates (CL27e).

copper, nickel, and zinc, are found to be contained within concentrates (either by gross weight or by content). Other mineral commodity categories, such as phosphate, include many specific downstream processed forms of minerals and materials, including diammonium phosphate, monoammonium phosphate, and trisodium phosphate.

This feature class presents data on mineral commodities in the primary form. Primary commodities refer to virgin materials such as ore, concentrates, other intermediate products, and refined metals originating from ore extraction activities. Exports of mineral commodities in the form of secondary materials, such as scrap aluminum and steel, were not specifically addressed. However, the tonnage of commodities recovered from scrap may be included in the exports of shipments from mineral processing plants that incorporate scrap into their feed (most likely including aluminum, copper, lead, and zinc smelters and refineries).

The primary source for the original port listing - the World Port Index (WPI) — was obtained from the National Geospatial-Intelligence Agency. Additional ports within the region were added if necessary during the course of research. The WPI did not contain any information about the mineral commodities exported but instead summarized the actual physical port characteristics, such as harbor depth and number of dockside servicing terminals. NMIC researchers investigated the specific mineral commodities, sometimes obtaining and verifying data contained within bills of lading from port authorities, and at other times using and verifying publicly available information contained in press reports and company websites. Table 25 describes the user-defined data attribute fields within the feature class and table 26 shows summary statistics. The full mineral commodity exporting port feature class, as well as metadata explaining all attribute field values, codes, and abbreviations, is available as a USGS data release (Baker and others, 2016) through the USGS ScienceBase data release page, available at https://doi.org/10.5066/F7BZ6460.

Due to relatively limited data availability on mineral commodity export details, forms of commodities exported vary. This dataset is not intended to be comprehensive in scope. It may be omitting ports or mineral commodities or forms of mineral commodities. Table 27 shows the total number of records per mineral commodity along with the number of different forms of the commodities. 
Table 26. Summary statistics on mineral commodity exporting ports of Latin America and the Caribbean, 2010-12, from the PORTS_LAC feature class.

\begin{tabular}{l|cccl}
\hline Country & $\begin{array}{c}\text { Number } \\
\text { of unique } \\
\text { ports }\end{array}$ & $\begin{array}{c}\text { Number of unique } \\
\text { mineral commodity } \\
\text { categories exported } \\
\text { per country }\end{array}$ & $\begin{array}{c}\text { Greatest number } \\
\text { of export data } \\
\text { records at single } \\
\text { port }\end{array}$ & Port with greatest number of export \\
data records
\end{tabular}

Table 27. Mineral commodity-level statistics for mineral commodity exporting ports in Latin America and the Caribbean, 2010-12. Continued

[NA, not applicable or not available]

\begin{tabular}{|c|c|c|c|}
\hline $\begin{array}{l}\text { Mineral } \\
\text { commodity } \\
\text { category } \\
\text { exported }\end{array}$ & $\begin{array}{l}\text { Total number of } \\
\text { export records } \\
\text { per mineral } \\
\text { commodity } \\
\text { category }\end{array}$ & $\begin{array}{l}\text { Number of } \\
\text { specific forms } \\
\text { of the mineral } \\
\text { commodity } \\
\text { exported }\end{array}$ & Specific forms exported \\
\hline Aggregate & 2 & 2 & Limestone, riverstone \\
\hline Alumina & 8 & 1 & Alumina \\
\hline Aluminum & 4 & 3 & Metal, metal and shapes \\
\hline Barite & 2 & 2 & Barium carbonate, crude barite \\
\hline Bauxite & 5 & 4 & Bauxite, chemical-grade bauxite, metallurgical-grade bauxite, refractory bauxite \\
\hline Cadmium & 1 & 1 & Metal \\
\hline Cement & 10 & 3 & Bulk, clinker, portland \\
\hline Chromite & 1 & 1 & Ore \\
\hline Clay & 2 & 1 & Bentonite \\
\hline Coal & 12 & 4 & Anthracite, metallurgical and steam, unknown, thermal \\
\hline Cobalt & 1 & 1 & Contained in unrefined nickel \\
\hline Copper & 41 & 5 & $\begin{array}{l}\text { Anode, cathode, concentrate (includes "concentrate (gross weight)," "contained in } \\
\text { concentrate," and "ores and concentrates"), refined metal, wire }\end{array}$ \\
\hline Ferroalloys & 7 & 4 & Ferromanganese, ferronickel, ferroniobium, ferrosilicon \\
\hline Fluorspar & 4 & 2 & Acid-grade, unknown (includes NA) \\
\hline Gold & 9 & 2 & Contained in concentrate, contained in copper concentrates \\
\hline Indium & 2 & 2 & In zinc concentrates, in Cajamarquilla zinc refinery residues \\
\hline
\end{tabular}


Table 27. Mineral commodity-level statistics for mineral commodity exporting ports in Latin America and the Caribbean, 2010-12.Continued

[NA, not applicable or not available]

\begin{tabular}{|c|c|c|c|}
\hline $\begin{array}{l}\text { Mineral } \\
\text { commodity } \\
\text { category } \\
\text { exported }\end{array}$ & $\begin{array}{l}\text { Total number of } \\
\text { export records } \\
\text { per mineral } \\
\text { commodity } \\
\text { category }\end{array}$ & $\begin{array}{l}\text { Number of } \\
\text { specific forms } \\
\text { of the mineral } \\
\text { commodity } \\
\text { exported }\end{array}$ & Specific forms exported \\
\hline Iron & 28 & 7 & Dross, iron ore, lump ore and sinter feed (gross weight), ore, pellets, pig iron, sinter \\
\hline Kaolin & 2 & 1 & Kaolin clay \\
\hline Lead-silver & 1 & 1 & Concentrate \\
\hline Lead-zinc & 1 & 1 & Concentrate \\
\hline Lithium & 3 & 3 & Carbonate, chloride, hydroxide \\
\hline Magnesium & 3 & 2 & Oxide, refined metal \\
\hline Manganese & 5 & 3 & Ore, refined metal, unknown (includes NA) \\
\hline Niobium & 1 & 1 & Niobium oxide \\
\hline Phosphate & 10 & 6 & $\begin{array}{l}\text { Dicalcium phosphate (DCP), diammonium, unspecified fertilizer (gross weight or } \\
\text { tonnage), monoammonium phosphate, ore, trisodium phosphate (TSP) }\end{array}$ \\
\hline Potash & 2 & 1 & Fertilizer (gross weight) \\
\hline Potassium & 3 & 3 & Chloride, nitrate, sulfate \\
\hline Salt & 4 & 3 & Bulk (various forms), rock, various forms \\
\hline Selenium & 1 & 1 & Metal \\
\hline Silver & 6 & 1 & Contained in copper concentrates \\
\hline Silver-zinc & 1 & 1 & Concentrate \\
\hline Zinc & 14 & 5 & Concentrate, ingots, metal and refined metal, oxide, unwrought \\
\hline
\end{tabular}

\section{Cartographic elements-F_CARTO feature dataset}

\section{Cartographic elements-CITIES, COUNTRY, LAC_ELEVATION, RIVERS, USA feature classes}

Base cartographic elements were incorporated from a range of copyright-free or open-source shapefiles to represent political and physical features. International boundaries were derived from the U.S. Department of State (DOS)'s Large-Scale International Boundary (LSIB) dataset. The LSIB was created by DOS's Office of the Cartographer and is one of the most accurate worldwide international boundary vector line files available (U.S. Department of State, 2017). These data include the World Vector Shoreline data and are an up-to-date representation of international boundaries. Physical and political features such as major rivers, capital 
cities, and other cities in the region were derived from base Esri files contained as part of their Data and Maps package, with additional regional cities of local importance added to the feature class via Google arth $^{\mathrm{TM}}$ for spatial reference. The LAC_ELEVATION feature class is a digital elevation model (DEM) that was created from original 90-meter data resampled to 250-meter resolution, obtained from the Consortium of International Agricultural Research Centers' Consortium for Spatial Information (CGIAR-CSI). To reduce file size, the DEM data were down-sampled by nearest neighbor approximation and may not match the original satellite data (Jarvis and others, 2008). One layer is included in this feature dataset solely for cartographic rendering purposes: a mask layer of the United States (as it is not part of this project's study area). The mask layer is to show the actual location of the United States in relation to the study area.

\section{Geodatabase annotation groups-G_ANNO feature dataset}

\section{Geodatabase annotation groups}

The $G_{-} A N N O$ feature dataset contains annotation feature classes stored in one centralized location within the geodatabase. These annotation featue classes correspond to the map labels on the geospatial PDF map and to the on-screen labels in the GIS map document (table 28). Within the geospatial PDF map document, annotation feature class layers immediately precede the layer to which they refer. They contain the word "labels" in the map layer description in the menu and contain the suffix "ANNO" to denote that they are an annotation group within the geodatabase. Layers that contain the prefix "XMark_" are a functional cartographic label used to indicate the visible layers in the upper right-hand area of the map.

Table 28. Annotation feature classes in the G_ANNO feature dataset and their corresponding map document feature class and corresponding geospatial PDF map layer, in alphabetical order by annotation feature class.

[Conv., conventional; RPP, recoverable proven plus probable resources; LNG, liquefied natural gas]

\begin{tabular}{|c|c|c|}
\hline $\begin{array}{l}\text { Annotation feature } \\
\text { class }\end{array}$ & $\begin{array}{l}\text { Geodatabase feature } \\
\text { class }\end{array}$ & Map document layer and geospatial PDF map layer name \\
\hline CITIES_ANNO & CITIES & Capitals and other cities (CITIES) \\
\hline CONV_OIL_PROD_CNTRY_ANNO & OG_COUNTRY & Conventional oil, by country (OG_COUNTRY) \\
\hline CONV_OIL_PROD_PP_ANNO & OG_PETRO_PROV & Conventional oil, by petroleum province (OG_PETRO_PROV) \\
\hline CONV_OIL_RPP_CNTRY_ANNO & OG_COUNTRY & Conventional oil, RPP, by country (OG_COUNTRY) \\
\hline COUNTRY_ANNO & COUNTRY, USA & International boundaries (COUNTRY), United States (USA) \\
\hline CU_PORPH_TRACTS_ANNO & CU_PORPH_TRACTS & Porphyry copper tracts (CU_PORPH_TRACTS) \\
\hline EXPLORE_LAC_ANNO & EXPLORE_LAC & Mineral exploration and development sites (EXPLORE_LAC) \\
\hline LNG_ANNO & LNG & Liquefied natural gas terminals (LNG) \\
\hline MINFAC_MINEPLANT_ANNO & MINFAC_LAC & Combined mine-processing plant operations (MINFAC_MINEPLANT) \\
\hline MINFAC_OGFIELDS_ANNO & MINFAC_LAC & Oil and gas fields (MINFAC_OGFIELDS) \\
\hline MINFAC_OGREFINE_ANNO & MINFAC_LAC & $\begin{array}{l}\text { Oil and gas refineries and (or) petrochemical complexes } \\
\text { (MINFAC_OGREFINE) }\end{array}$ \\
\hline PETRO_PROV_ANNO & PETRO_PROV & USGS petroleum provinces (PETRO_PROV) \\
\hline PORTS_LAC_ANNO & PORTS_LAC & Mineral commodity exporting ports (PORTS_LAC) \\
\hline POWER_LAC_ANNO & POWER_LAC & Electric power generating facilities (POWER_LAC) \\
\hline RIVERS_ANNO & RIVERS & Major rivers (RIVERS) \\
\hline
\end{tabular}




\section{References Cited}

[Entries marked with an asterisk $(*)$ at the beginning of the reference indicate a reference for data included in the geodatabase, geospatial PDF map, or metadata that may not be cited within the body of the text. References not included in the main body of the text may be referring to information presented in appendix 2 (Case study 1: Iron ore mining and transportation infrastructure in Brazil's Iron Quadrangle) and appendix 3 (Case study 2: Bauxite mining and alumina production in Jamaica).]

*Agência Nacional de Energia Elétrica [Brazil; National Electrical Energy Agency], 2016, Download KMZ: Agência Nacional de Energia Elétrica web page, accessed February 6, 2017, at http://sigel.aneel.gov.br/kmz.html.

*Agência Nacional do Petróleo, Gás Natural e Biocombustíveis [Brazil; National Petroleum, Natural Gas, and Biocombustibles Agency], 2017, Dados de E\&P—Dados Georreferenciados dos Blocos em Exploração e Campos de Produção [Explortion and production data-Exploration blocks and producing fields georeferenced data]: Agência Nacional do Petróleo, Gás Natural e Biocombustíveis web page, accessed April 30, 2017, at http://www.anp.gov.br/ wwwanp/exploracao-e-producao-de-oleo-e-gas/gestao-decontratos-de-e-p/dados-de-e-p.

Alcoa Inc., 2014, Alcoa to sell stake in Jamalco to Noble: Alcoa Inc. press release, October 15, accessed June 6, 2016, at http://news.alcoa.com/press-release/alcoa-sell-stakejamalco-noble.

Almánzar, Francisco, Baker, M.S., Elias, Nurudeen, and Guzmán, Eric, 2010, Mineral facilities of Europe:

U.S. Geological Survey Open-File Report 2010-1257, 1 pl., 47-p. table, accessed April 5, 2017, at https://pubs.usgs.gov/ of/2010/1257.

Anderson, Charles, 2015, Conflict minerals from the Democratic Republic of the Congo-Tin processing plants, a critical part of the tin supply chain (ver. 2.0, July 31, 2015): U.S. Geological Survey Fact Sheet 2015-3022, 4 p., accessed April 5, 2017, at https://doi.org/10.3133/ fs 20153022 .

Anderson, C.S., 2016a, Bismuth: U.S. Geological Survey Mineral Commodity Summaries 2015, p. 36-37, accessed April 5, 2017, at https://minerals.usgs.gov/minerals/pubs/ commodity/bismuth/mcs-2016-bismu.pdf.

Anderson, C.S., 2016b, Selenium: U.S. Geological Survey Mineral Commodity Summaries 2015, p. 148-149, accessed April 5, 2017, at https://minerals.usgs.gov/minerals/pubs/ commodity/selenium/mcs-2016-selen.pdf.

Anderson, C.S., 2016c, Tellurium: U.S. Geological Survey Mineral Commodity Summaries 2015, p. 168-169, accessed April 5, 2017, at https://minerals.usgs.gov/minerals/pubs/ commodity/selenium/mcs-2016-tellu.pdf.
Anderson, C.S., 2016d, Tin: U.S. Geological Survey Mineral Commodity Summaries 2015, p. 174-175, accessed April 5, 2017, at https://minerals.usgs.gov/minerals/pubs/ commodity/tin/mcs-2016-tin.pdf.

*Asociación Colombiana de Generadores de Energía Eléctrica (ACOLGEN) [Colombia], 2017, Mapa de Ubicación de Centrales-Centrales de Asociados mayors a $50 \mathrm{MW}$ : Asociación Colombiana de Generadores de Energía Eléctrica web page, accessed February 6, 2017, at http://www.acolgen.org.co/index.php/2013-01-31-06-37-23/ mapa-de-ubicacion.

Ausenco Ltd., 2016, Samarco iron concentrate pipelines system-Longest iron concentrate pipeline system in the world: Ausenco Ltd. case studies web page, accessed June 6, 2016, at http://www.ausenco.com/case-studies/ samarco.

*Autoridad de Fiscalización y Control de Electricidad [Bolivia], 2016a, Mapa plantas de generación eléctrica Bolivia [Map of electricity-generating plants in Bolivia]: GeoBolivia web catalog, accessed February 6, 2017, at http://geo.gob.bo/geonetwork/srv/eng/catalog.search\#/ metadata/a298df7e-4a49-4ee4-acba-06b8347fb29e.

*Autoridad de Fiscalización y Control de Electricidad [Bolivia], 2016b, Mapa red eléctrica de alta tensión en Bolivia [Map of the high-voltage power grid in Bolivia]: GeoBolivia web catalog, accessed February 6, 2017, at http://geo.gob.bo/geonetwork/srv/eng/catalog.search\#/ metadata/e2e0f864-2c6e-4d04-a519-25ddd8742c72.

Baker, M.S., Bleiwas, D.I., and Goonan, T.G., 2016, Mineral commodity exporting ports of Latin America and the Caribbean: U.S. Geological Survey data release, accessed April 5, 2017, at https://doi.org/10.5066/F7BZ6460.

Baker, M.S., and Buteyn, S.D., 2016, Mineral facilities of Latin America and the Caribbean: U.S. Geological Survey data release, accessed April 5, 2017, at https://doi. org/10.5066/F7MG7MM6.

Baker, M.S., Elias, Nurudeen, Guzmán, Eric, and Soto-Viruet, Yadira, 2010a, Mineral facilities of Asia and the Pacific: U.S. Geological Survey Open-File Report 2010-1254, 1 pl., 51-p. table, accessed April 5, 2017, at https://pubs.usgs.gov/ of $/ 2010 / 1254$.

Baker, M.S., Elias, Nurudeen, Guzmán, Eric, and Soto-Viruet, Yadira, 2010b, Mineral facilities of Northern and Central Eurasia: U.S. Geological Survey Open-File Report 2010-1255, 1 pl., 27-p. table, accessed April 5, 2017, at https://pubs.usgs.gov/of/2010/1255.

Baker, M.S., and Wilburn, D.R., 2016, Mineral exploration sites of Latin America and the Caribbean: U.S. Geological Survey data release, accessed April 5, 2017, at https://doi. org/10.5066/F7GQ6VWG. 
Bank of Jamaica, 2016, Jamaica in figures, 2015: Kingston, Jamaica, Bank of Jamaica, 2. p., accessed April 5, 2017, at http://www.boj.org.jm/uploads/pdf/jam_figures/jam figures_2015.pdf.

Bedinger, G.M., 2016, Titanium mineral concentrates (ilmenite) : U.S. Geological Survey Mineral Commodity Summaries 2015, p. 178-179, accessed April 5, 2017, at https://minerals.usgs.gov/minerals/pubs/commodity/ titanium/mcs-2016-timin.pdf.

Bermúdez-Lugo, Omayra, 2004, The mineral industries of the islands of the Caribbean, in Area reports - International-Latin America and Canada: U.S. Geological Survey Minerals Yearbook 2002, v. III, p. 12.1-12.12., 1 table, accessed April 5, 2017, at http://minerals.usgs.gov/minerals/ pubs/country/2001/caribbeanmyb01r.pdf.

Bermúdez-Lugo, Omayra, 2014, Conflict minerals from the Democratic Republic of the Congo-Global tungsten processing plants, a critical part of the tungsten supply chain (ver. 1.1, August 2014): U.S. Geological Survey Fact Sheet 2014-3069, 4 p., accessed April 5, 2017, at https://doi.org/10.3133/fs20143069.

Bermúdez-Lugo, Omayra, and Menzie, W.D., 2015, The Ebola virus disease outbreak and the mineral sectors of Guinea, Liberia, and Sierra Leone: U.S. Geological Survey Fact Sheet 2015-3033, 8 p., accessed April 5, 2017, at https://doi.org/10.3133/fs20153033.

Bernstein, Rachel, Eros, Mike, and Quintana-Velazquez, Meliany, 2006, Mineral facilities of Latin America and Canada: U.S. Geological Survey Open-File Report 2006-1375, 1 pl., 47-p. table, accessed April 5, 2017, at https://pubs.usgs.gov/of/2006/1375/.

BHP Billiton Ltd., 2002, Annual report 2001, part CDescription of business: BHP Billiton Ltd., 110 p., accessed June 6, 2016, at http://www.bhpbilliton.com/ /media/bhp/ documents/investors/reports/2001/2001bhpbillitonltdannual report_partc.pdf?la $=$ en.

Bray, E.L., 2016a, Bauxite: U.S. Geological Survey Mineral Commodity Summaries 2015, p. 32-33, accessed April 5, 2017, at https://minerals.usgs.gov/minerals/pubs/ commodity/bauxite/mcs-2016-bauxi.pdf.

Bray, E.L., 2016b, Magnesium compounds: U.S. Geological Survey Mineral Commodity Summaries 2015, p. 102-103, accessed April 5, 2017, at https://minerals.usgs.gov/minerals/ pubs/commodity/magnesium/mcs-2016-mgcom.pdf.

Bray, E.L., 2016c, Bauxite and alumina [advance release], in Metals and minerals: U.S. Geological Survey Minerals Yearbook 2014, v. I, p. 10.1-10.13, accessed March 26, 2017, at https://minerals.usgs.gov/minerals/pubs/ commodity/bauxite/myb1-2014-bauxi.pdf.
Brininstool, Mark, 2016, Copper: U.S. Geological Survey Mineral Commodity Summaries 2015, p. 54-55, accessed April 5, 2017, at https://minerals.usgs.gov/minerals/pubs/ commodity/copper/mcs-2016-coppe.pdf.

Burma, Christine, and Hong, C.H., 2014, U.S. gas boom turns global as LNG exports to shake up markets: Bloomberg News, October 1, 2014, accessed August 2016 at http://www.bloomberg.com/news/articles/2014-09-30/ u-s-gas-boom-turns-global-as-lng-exports-set-to-shakeup-market.

Campbell, Keith, 2013, The state of mining in South America-an overview: Mining Weekly, June 21, 2013, accessed August 2016 at http://www.miningweekly.com/ print-version/mining-and-south-america-today-2013-06-21.

*CartoCrítica, 2017, Industrias extractivas y concesiones: CartoCrítica interactive web map with data from the Comisión Nacional de Hidrocarburos of Mexico, accessed February 6, 2017, at http://www.cartocritica.org.mx/2015/ industrias-extractivas/.

Cawthorne, Andrew, 2016, Drought-hit Venezuela awaits rain at crucial Guri dam: Thomson Reuters, April 13, 2016, accessed April 14, 2016, at http://www.reuters.com/article/ us-venezuela-energy-idUSKCN0XA1WL.

*Cereijo, Manuel, 2010, Republic of Cuba-Power sector infrastructure assessment: Cuba Transition Project, Institute for Cuban and Cuban-American Studies, University of Miami, 79 p., accessed February 6, 2017, at https://web. archive.org/web/20121203044053/http://ctp.iccas.miami. edu/Appendices/Appendix_D_Power/Cereijo_2010a.pdf.

*CGX Energy Inc., 2016, CGX at a glance-Leasing overview map: CGX Energy Inc. web page, accessed April 2016 at http://cgxenergy.ca/At-A-Glance.aspx.

*Comisión Nacional de Energía Eléctrica [Guatemala; National Electric Energy Commission], 2017, Mapa de presas en Guatemala: Comisión Nacional de Energía Eléctrica web page, accessed February 6, 2017, at http://www.cnee.gob.gt/wp/?page_id=239.

*Comisión Nacional de Hidrocarburos [Mexico; National Hydrocarbons Commission], 2016, Portal de Información Técnica del CNIH [Technical Information Portal of the National Hydrocarbons Commission]: Comisión Nacional de Hidrocarburos interactive web map browser, accessed February 6, 2017, at http://portal.cnih.cnh.gob.mx/iicnih/. 
Companhia Hispano-Brasileira de Pelotização, 2014, Companhia Hispano-Brasileira de Pelotização-HISPANOBRAS, Demonstrações financeiras em 31 de dezembro de 2013 [Financial statements as of December 31, 2013]: Rio de Janeiro, Brazil, Companhia Hispano-Brasileira de Pelotização, 25 p., accessed June 6, 2016, at http://www.vale. $\mathrm{com} / \mathrm{EN} /$ investors/information-market/financial-statements/ ControladasColigadasDocuments/DC_Hispanobras_2013. pdf.

Corathers, L.A., 2016, Manganese: U.S. Geological Survey Mineral Commodity Summaries 2015, p. 106-107, accessed April 5, 2017, at https://minerals.usgs.gov/minerals/pubs/ commodity/manganese/mcs-2016-manga.pdf.

*Corporación Eléctrica del Ecuador, 2014, Sistema Nacional de Transmision (SNT) - Esquema geografico del SNT: Corporación Eléctrica del Ecuador web page, accessed February 6, 2017, at https://www.celec.gob.ec/transelectric/ images/stories/baners_home/Plan\%20expansion/mapa $\% 20$ snt $\% 20 \mathrm{a} \% 20$ diciembre\%202013.pdf.

*Corporación Eléctrica Nacional S.A. (CORPOLEC) [Venezuela], 2017, Transmision: Corporación Eléctrica Nacional S.A. web page, accessed February 6, 2017, at http://www. corpoelec.gob.ve/transmisi $\% \mathrm{C} 3 \% \mathrm{~B} 3 \mathrm{n}$.

Crangle, R.D., Jr., 2016, Boron: U.S. Geological Survey Mineral Commodity Summaries 2015, p. 38-39, accessed April 5, 2017, at https://minerals.usgs.gov/minerals/pubs/ commodity/boron/mcs-2016-boron.pdf.

Cunningham, C.G., Zappettini, E.O., Vivallo S., Waldo, Celada, C.M., Quispe, Jorge, Singer, D.A., Briskey, J.A, Sutphin, D.M., Gajardo M., Mariano, Diaz, Alejandro, Portigliati, Carlos, Berger, V.I., Carrasco, Rodrigo, and Schulz, K.J., 2008, Quantitative mineral resource assessment of copper, molybdenum, gold, and silver in undiscovered porphyry copper deposits in the Andes Mountains of South America: U.S. Geological Survey Open-File Report 2008-1253, 282 p., 1 CD-ROM, accessed April 5, 2017, at https://pubs.usgs.gov/of/2008/1253/.

*Daily Ambito Financiero, 2015, Senado convirtío en ley estatización de trenes: Daily Ambito Financiero [Buenos Aires, Argentina], April 15, 2015, accessed March 2016 at http://www.ambito.com/786700-senado-convirtio-en-leyestatizacion-de-trenes.

*Departamento Nacional de Produção Mineral [Brazil; National Department of Mineral Production], 2016, Sumário mineral 2015-Produção Mineral Brasileira [Mineral summary 2015-Brazilian mineral production]: Departamento Nacional de Produção Mineral, April 5, 2016, accessed June 6, 2016, at http://www.dnpm.gov.br/dnpm/ colecoes/colecao-de-sumarios-sumario-mineral.
*Dicken, C.L., Dunlap, Pamela, Parks, H.L., Hammarstrom, J.M., and Zientek, M.L., 2016, Spatial database for a global assessment of undiscovered copper resources: U.S. Geological Survey Scientific Investigations Report 2010-5090-Z, 29 p., and GIS data, accessed August 2016 at https://doi. org/10.3133/sir20105090Z.

Dixon, A.P., and Nakagawa, Masami, 2016, Geothermal energy for mining in Chile - Current situation and opportunities: Proceedings of the 41st workshop on geothermal reservoir engineering, Stanford University, February 22-24, 2016, accessed April 24, 2017, at https://pangea.stanford. edu/ERE/db/GeoConf/papers/SGW/2016/Dixon.pdf.

Dorr, J.V.N., and Barbosa, A.L. de M., 1963, Geology and Ore Deposits of the Itabira District, Minas Gerais, Brazil, U.S. Geological Survey Professional Paper 341-C, accessed June 6, 2016, at https://pubs.er.usgs.gov/publications/ pp341C.

Economic Commission for Latin America and the Caribbean, 2016, Foreign direct investment towards the region fell $9.1 \%$ in 2015 to total $\$ 179.10$ billion dollars: Economic Commission for Latin America and the Caribbean press release, June 15, 2016, accessed September 2016 at http://www.cepal.org/en/pressreleases/foreign-directinvestment-towards-region-fell-91-2015-total-17910-billiondollars.

Economic Commission for Latin America and the Caribbean, 2017, Latin America and the Caribbean - regional economic profile, data statistics and indicators: Economic Commission for Latin America and the Caribbean web page, accessed March 8, 2017, at http://estadisticas.cepal. org/cepalstat/WEB_CEPALSTAT/estadisticasIndicadores. asp? idioma $=\mathrm{i}$.

*Economic Consulting Associates Ltd., 2010, The potential of regional power sector integration - Central American Electric Interconnection System (SIEPAC) transmission and trading case study: Economic Consulting Associates Ltd., March 2010, accessed June 2016 at http://www.esmap.org/ sites/esmap.org/files/BN004-10_REISP-CD_Central\%20 American\%20Electric\%20Interconnection\%20SystemTransmisison\%20\&\%20Trading.pdf.

*Economist, The, 2005, Energy in the southern cone-Gas ring: The Economist (map content reproduced with permission), August 18, 2005, accessed June 21, 2016, at http://www.economist.com/node/4301018.

*Ecopetrol S.A., 2011, Form 20-F for the fiscal year ended December 31, 2010: U.S. Securities and Exchange Commission, July 25, 2011, accessed June 2016 at http://www.sec. gov/Archives/edgar/data/1444406/000114420411040868/ v228285_20f.htm. 
*Energy and Climate Partnership of the Americas, 2016, Advanced power sector integration and cross border trade in electricity-Central America and SIEPAC: Energy and Climate Partnership of the Americas web page, accessed June 2016 at http://www.ecpamericas.org/initiatives/ ?id $=70$.

*Ente Nacional Regulador de la Electricidad [Argentina; National Electricity Regulatory Body], 1999, Informe annual 1999 [Annual report 1999]: Ente Nacional Regulador de la Electricidad, 301 p., accessed August 2016 at http://www.enre.gov.ar/web/web.nsf/Files/informe1999. pdf/\$FILE/informe1999.pdf.

Eros, J.M., and Candelario-Quintana, Luissette, 2006, Mineral facilities of Africa and the Middle East: U.S. Geological Survey Open-File Report 2006-1135, 1 pl., 1 table, accessed April 5, 2017, at https://pubs.usgs.gov/ of/2006/1135/.

*Esri, 2012, Bolivian pipeline company expands into mobile asset management: Esri news release, Fall 2012, accessed October 2016 at http://www.esri.com/news/arcnews/ fall12articles/bolivian-pipeline-company-expands-intomobile-asset-management.html.

*Esri, 2017a, World cities-Esri data and maps: ArcGIS Online data layer package, April 21, accessed April 24, 2017, at http://www.arcgis.com/home/item.html?id=dfab 3b294ab24961899b2a98e9e8cd3d [modified by author to include regional data not included in this base map layer].

*Esri, 2017b, World major rivers-Esri data and maps: ArcGIS Online data layer package, January 17, accessed April 24, 2017, at http://www.arcgis.com/home/item. $\mathrm{html}$ ?id=44e8358cf83a4b43bc863646cd695945 [modified by author to include regional data not included in this base map layer, including a river course correction to the Paraguay River].

Flavin, Christopher, Gonzalez, Milena, Majano, A.M., Ochs, Alexander, Rocha Oliveira, M.G. da, and Tagwerker, Philipp, 2014, Study on the devleopment of the renewable energy market in Latin America and the Caribbean: InterAmerican Development Bank, Office of Evaluation and Oversight, working paper IDB RFP \#14-002, November, accessed August 2016 at https://publications.iadb.org/ bitstream/handle/11319/6711/Study-on-the-Developmentof-the-Renewable-Energy-Market-in-Latin-America-andthe-Caribbean.pdf.

Fortier, S.M., DeYoung, J.H., Jr., Sangine, E.S., and Schnebele, E.K., 2015, Comparison of U.S. net import reliance for nonfuel mineral commodities-A 60-year retrospective (1954-1984-2014): U.S. Geological Survey Fact Sheet 2015-3082, 4 p., accessed April 5, 2017, at https://doi. org/10.3133/fs20153082.
*French, C.D., and Schenk, C.J., comps., 2004, Map showing geology, oil and gas fields, and geologic provinces of the Caribbean region: U.S. Geological Survey Open-File Report 97-470-K, accessed September 2016 at https://pubs.usgs.gov/of/1997/ofr-97-470/OF97-470K.

Gambogi, J., 2016, Rare earths: U.S. Geological Survey Mineral Commodity Summaries 2015, p. 134-135, accessed April 5, 2017, at https://minerals.usgs.gov/minerals/pubs/ commodity/rare_earths/mcs-2016-raree.pdf.

*Gasoducto Cruz del Sur S.A., 2017, Gasoducto-Trazado: Gasoducto Cruz del Sur S.A. web page, accessed March 15, 2017, at http://www.gasoductocruzdelsur.com.uy/ gas_trazados.php.

George, M.W., 2015, Conflict minerals from the Democratic Republic of the Congo - Gold supply chain (ver. 1.1, December 10, 2015): U.S. Geological Survey Fact Sheet 2015-3075, 4 p., accessed April 5, 2017, at https://doi.org/10.3133/fs20153075.

George, M.W., 2016a, Gold: U.S. Geological Survey Mineral Commodity Summaries 2015, p. 72-73, accessed April 24, 2017, at https://minerals.usgs.gov/minerals/pubs/ commodity/gold/mcs-2016-gold.pdf.

George, M.W., 2016b, Silver: U.S. Geological Survey Mineral Commodity Summaries 2015, p. 152-153, accessed April 24, 2017, at https://minerals.usgs.gov/minerals/pubs/ commodity/silver/mcs-2016-silve.pdf.

Gleaner, The, 2014, RUSAL acquires remaining government stake in WINDALCO: The Gleaner [Kingston, Jamaica], December 12, 2014, accessed June 2016 at http://jamaica-gleaner.com/article/news/20141212/ rusal-acquires-remaining-government-stake-windalco.

Gleaner, The, 2016, Alpart sold for US \$300m-UC RUSAL seals deal with JISCO in Beijing: The Gleaner [Kingston, Jamaica], July 20, 2016, accessed April 5, 2017, at http://jamaica-gleaner.com/article/business/20160720/ alpart-sold-us300m-uc-rusal-seals-deal-jisco-beijing.

*Gray, F., Hammarstrom, J.M., Ludington, S., Zürcher, L., Nelson, C.E., Robinson, G.R., Jr., Miller, R.J., and Moring, B.C., 2014, Porphyry copper assessment of Central America and the Caribbean Basin: U.S. Geological Survey Scientific Investigations Report 2010-5090-I, 81 p., and GIS data, accessed August 2016 at https://doi.org/10.3133/ sir20105090I.

Guberman, D.E., 2016a, Antimony: U.S. Geological Survey Mineral Commodity Summaries 2016, p. 24-25, accessed April 24, 2017, at https://minerals.usgs.gov/minerals/pubs/ commodity/antimony/mcs-2016-antim.pdf. 
Guberman, D.E., 2016b, Lead: U.S. Geological Survey Mineral Commodity Summaries 2015, p. 96-97, accessed April 24, 2017, at https://minerals.usgs.gov/minerals/pubs/ commodity/lead/mcs-2016-lead.pdf.

*Hammarstrom, J.M., Robinson, G.R., Jr., Ludington, Steve, Gray, Floyd, Drenth, B.J., Cendejas-Cruz, Francisco, Espinosa, Enrique, Pérez-Segura, Efrén, Valencia-Moreno, Martín, Rodríguez-Castañeda, José Luis, Vásquez-Mendoza, Rigoberto, and Zürcher, Lukas, 2010, Porphyry copper assessment of Mexico: U.S. Geological Survey Scientific Investigations Report 2010-5090-A, 176 p., accessed October 2016 at https://pubs.usgs.gov/ sir/2010/5090/a/.

Hastorun, Sinan, Renaud, K.M., and Lederer, G.W., 2016, Recent trends in the nonfuel minerals industry of Iran: U.S. Geological Survey Circular 1421, 18 p., accessed April 24, 2017, at https://doi.org/10.3133/cir1421.

*ICR News, 2013, Tensions between Costa Rica and Nicaragua over oil concessions could lead to conflict: ICR News, July 23, 2013, accessed August 2016 at http://insidecostarica.com/2013/07/23/tensions-between-costa-rica-andnicaragua-over-oil-concessions-could-lead-to-conflict/.

IHS Global Inc., 2016, International exploration and production database: IHS Global database, accessed May 2, 2016, at https://www.ihs.com/pdf/International-ExplorationProduction-Database-IHS_165378110913044932.pdf. [Note: database is a subscription service not available via the web. Link is to an informational brochure.]

*Instituto Costarricense de Electricidad, 2006, Sistema de Transmisión Centraamericana-Año 2006 [Central American Transmission System-2006]: Instituto Costarricense de Electricidad, accessed July 2016 at http://www.geni. org/globalenergy/library/national_energy_grid/centralamerican-grid/graphics/centralamericagrid.gif.

*Instituto Nacional de Estadística y Geografía [Mexico; National Institute of Statistics and Geography], 2017, Datos vectoriales escala 1:1000000-descarga, Generación, transmisión, de energía, y conductos (conducto, línea transmisión, planta generadora): Instituto Nacional de Estadística y Geografía, accessed February 6, 2017, at http://www. inegi.org.mx/geo/contenidos/topografia/topografia_1m.aspx.

*International Council of Large Energy Systems (CIGRE), 2016, The electric power system - Chile: International Council of Large Energy Systems presentation, accessed August 2016 at http://www.cigre.org/var/cigre/storage/ original/application/6a789c1375a22a39e14a284bee7ff988. pdf.

International Gas Union, 2016, 2016 world LNG report: International Gas Union, 88 p., accessed October 2016 at http://www.igu.org/publications/2016-world-lng-report.
International Hydropower Association, 2016, BrazilHydropower overview: International Hydropower Association web page, accessed August 2016 at https://www.hydropower.org/country-profiles/brazil.

*Itaipu Binacional, 2016, Integraçao ao Sistema paraguano [Integration with the Paraguayan system]: Itaipu Binacional web page, accessed March 2017 at https://www.itaipu.gov. br/energia/integracao-ao-sistema-paraguaio.

Jamaica Bauxite Institute, 2015a, Alumina \& bauxite plants and ports: Jamaica Bauxite Institute web page, accessed June 2016 at http://www.jbi.org.jm/.

Jamaica Bauxite Institute, 2015b, Bauxite and alumina plants: Jamaica Bauxite Institute web page, accessed June 2016 at http://www.jbi.org.jm/pages/bauxite_alumina_plants.

Jamaica Bauxite Institute, 2015c, Government involvement: Jamaica Bauxite Institute web page, accessed June 2016 at http://www.jbi.org.jm/pages/government_involvement.

Jamaica Bauxite Institute, 2015d, The making of an industry: Jamaica Bauxite Institute web page, accessed June 2016 at http://www.jbi.org.jm/pages/bauxite_alumina_plants.

Jamalco Inc., 2014, About us-Who we are: Jamalco Inc. web page, accessed June 2016 at http://www.jamalco.com/ jamalco/about-us.html.

*Jarvis, A., Reuter, H.I., Nelson, A., and Guevara, E., 2008, Hole-filled SRTM for the globe, Version 4: International Centre for Tropical Agriculture CGIAR-CSI SRTM 90m database, accessed October 26, 2016, at http://srtm.csi.cgiar. org.

Jasinski, S.M., 2016a, Phosphate rock: U.S. Geological Survey Mineral Commodity Summaries 2015, p. 124-125, accessed April 24, 2017, at https://minerals.usgs.gov/minerals/pubs/ commodity/phosphate_rock/mcs-2016-phosp.pdf.

Jasinski, S.M., 2016b, Potash: U.S. Geological Survey Mineral Commodity Summaries 2015, p. 128-129, accessed April 24, 2017, at https://minerals.usgs.gov/minerals/pubs/ commodity/potash/mcs-2016-potas.pdf.

Jaskula, B.W., 2016, Lithium: U.S. Geological Survey Mineral Commodity Summaries 2015, p. 100-101, accessed April 24, 2017, at https://minerals.usgs.gov/minerals/pubs/ commodity/lithium/mcs-2016-lithi.pdf.

*Johnson, K.M., Hammarstrom, J.M., Zientek, M.L., and Dicken, C.L., 2014, Estimate of undiscovered copper resources of the world, 2013: U.S. Geological Survey Fact Sheet 2014-3004, 3 p., accessed August 2016 at https://doi.org/10.3133/fs20143004. 
*Kashi, David, 2013, Colombia warns Nicaragua not to explore for oil in Caribbean waters claimed by Colombia: International Business Times, August 2, 2013, accessed February 6, 2017, at http://www.ibtimes.com/colombiawarns-nicaragua-not-explore-oil-caribbean-waters-claimedcolombia-1370589.

*Klett, T.R., Ahlbrandt, T.S., Schmoker, J.W., and Dalton, G.L., 1997, Ranking of the world's known oil and gas provinces by known petroleum volumes: USGS Open-File Report 97-463, accessed February 1, 2016, at https://pubs. usgs.gov/of/1997/ofr-97-463/97463.html.

Kuck, P.H., 2016, Nickel: U.S. Geological Survey Mineral Commodity Summaries 2015, p. 114-115, accessed April 24, 2017, at https://minerals.usgs.gov/minerals/pubs/ commodity/nickel/mcs-2016-nicke.pdf.

Lederer, G.W., 2016, Resource nationalism in IndonesiaEffects of the 2014 mineral export ban: U.S. Geological Survey Fact Sheet 2016-3072, 6 p., accessed April 24, 2017, at https://doi.org/10.3133/fs20163072.

McCrae, M.A., 2016, Why Samarco tailings dam failed: MINING.com, August 29, 2016, accessed October 2016 at http://www.mining.com/why-samarco-tailings-dam-failed/.

McIntyre, A., El-Ashram, A., Ronci, M., Reynaud, J., Che, N., Wang., K., Acevedo, S., Lutz, M., Strodel, F., Osueke, A., and Yun, H., 2016, Caribbean energy-Macro-related challenges: International Monetary Fund Working Paper WP/16/53, March, accessed April 24, 2017, at https://www. imf.org/external/pubs/ft/wp/2016/wp1653.pdf.

McRae, M.E., 2016a, Barite: U.S. Geological Survey Mineral Commodity Summaries 2015, p. 30-31, accessed April 24, 2017, at https://minerals.usgs.gov/minerals/pubs/ commodity/barite/mcs-2016-barit.pdf.

McRae, M.E., 2016b, Fluorspar: U.S. Geological Survey Mineral Commodity Summaries 2015, p. 62-63, accessed April 24, 2017, at https://minerals.usgs.gov/minerals/pubs/ commodity/fluorspar/mcs-2016-fluor.pdf.

*Ministerio de Electricidad y Energía Renovable [Ecuador; Ministry of Electricity and Renewable Energy], 2016, Sistema de transmission de extra alta tension de 500 MIL voltios [Extra high voltage transmission system-500,000 volts]: Ministerio de Electricidad y Energía Renovable web page, accessed February 9, 2017, at https:// www.celec.gob.ec/transelectric/index.php?option $=$ com content\&view=article\&id=481\&Itemid=534\&lang=es.
*Ministerio de Energía, Infraestructura de Datos Especiales [Chile], 2017, Infraestructura Asociada a Combustible (Gasoductos y oleoductos), Centrales Generación Eléctrica (Eólicas, hidroeléctrica, solares, termoeléctricas), Sistema de Transmisión Eléctrica (Linea de Transmisión SING, Linea de Transmisión SIC, Linea de Transmisión Aysen): Ministerio de Energía, Infraestructura de Datos Especiales interactive map, accessed February 6, 2017, at http://sig. minenergia.cl/sig-minen/moduloCartografico/composer/.

*Ministerio de Energía y Minas, Dirección General de Hidrocarburos [Guatemala], 2007, Exploración y explotación petrolera en Guatemala: Ministerio de Energía y Minas web page and presentation, accessed February 6, 2017, at http://www.mem.gob.gt/wp-content/uploads/2012/05/1.A\%C3\%B1o-2007-Numero-1-Historia.pdf.

*Ministerio de Energía y Minas [Dominican Republic], 2015, Discovering the hydrocarbon potential of the Dominican Republic: Ministerio de Energía y Minas, 16 p., accessed February 6, 2017, at http://www.mem.gob.do/images/docs/ ExecutiveSummaryDRModeling.pdf.

*Ministerio de Energía y Minas [Nicaragua; Ministry of Energy and Mines], 2008, Areas disponibles para exploracion y explotacion de hidrocarburos en Nicaragua [Map of available areas for hydrocarbon exploration and exploitation in Nicaragua]: Ministerio de Energía y Minas, September 2008, accessed June 18, 2016, at http://insidecostarica. com/wp-content/uploads/2013/07/mapa-petroleo.png.

*Ministerio de Energía y Minas [Peru], 2005, Principales centrales eléctricas 2005: Ministerio de Energía y Minas, 1 p., accessed February 6, 2017, at http://web.archive.org/ web/20090620063719/http://www.minem.gob.pe/archivos/ dge/mapas/centraleselctricas.pdf.

* Ministerio de Energía y Minas [Peru], 2011, Líneas de Transmisión Eléctrica 2011 [Electric transmission lines 2011]: Ministerio de Energía y Minas, accessed February 9, 2017, at http://www.minem.gob.pe/_publicacion.php? idSector $=6 \&$ idPublicacion $=395$.

*Ministerio de Energía y Minería [Argentina], 2017a, Generación eléctrica - Centrales de generación: Ministerio de Energía y Minería web page, accessed February 6, 2017, at http://datos.minem.gob.ar/generacion-electrica-centralesde-generacion-.

*Ministerio de Energía y Minería [Argentina], 2017b, Producción hidrocarburos - Concesiones de explotación: Ministerio de Energía y Minería web page, accessed February 6, 2017, at http://datos.minem.gob.ar/produccionhidrocarburos-concesiones-de-explotacion. 
*Ministerio de Energía y Minería [Argentina], 2017c, Producción hidrocarburos-Lotes de explotación: Ministerio de Energía y Minería web page, accessed February 6, 2017, at http://datos.minem.gob.ar/produccion-hidrocarburos-lotesde-explotacion.

*Ministerio de Energía y Minería [Argentina], 2017d, Producción hidrocarburos-Permisos de exploración: Ministerio de Energía y Minería web page, accessed March 14, 2017, at http://datos.minem.gob.ar/exploracion-hidrocarburospermisos-de-exploracion.

*Ministerio de Energía y Minería [Argentina], 2017e, Transporte eléctrico-AT Líneas: Ministerio de Energía y Minería Presidencia de la Nación web page, accessed February 6, 2017, at http://datos.minem.gob.ar/transporteelectrico-at-lineas-.

*Ministerio de Energía y Minería [Argentina], 2017f, Transporte hidrocarburos - Ductos troncales - Gasoductos: Ministerio de Energía y Minería web page, accessed February 6, 2017, at http://datos.minem.gob.ar/transportehidrocarburos-ductos-troncales-gasoductos.

*Ministerio de Energía y Minería [Argentina], 2017g, Transporte hidrocarburos-Ductos troncales-Oleoductos: Ministerio de Energía y Minería web page, accessed February 6, 2017, at http://datos.minem.gob.ar/transportehidrocarburos-ductos-troncales-oleoductos.

*Ministerio de Energía y Minería [Argentina], 2017h, Transporte hidrocarburos-Ductos troncales-JP Ducto: Ministerio de Energía y Minería web page, accessed February 6, 2017, at http://datos.minem.gob.ar/transportehidrocarburos-ductos-troncales-jp-ducto.

*Ministerio de Energía y Minería [Argentina], 2017i, Transporte hidrocarburos-Ductos troncales-Poliductos: Ministerio de Energía y Minería web page, accessed February 6, 2017, at http://datos.minem.gob.ar/transportehidrocarburos-ductos-troncales-poliductos.

*Ministerio de Energía y Minería [Argentina], 2017j, Transporte hidrocarburos-Ductos troncales-Propanoductos: Ministerio de Energía y Minería web page, accessed February 6, 2017, at http://datos.minem.gob.ar/transportehidrocarburos-ductos-troncales-propanoductos.

*Ministerio Hidrocarburos y Energía [Bolivia; Ministry of Hydrocarbons and Energy], 2005, Bloques, campos, sistemas de conducción de hidrocarburos [Blocks, fields, and hydrocarbon driving systems]: Ministerio Hidrocarburoas y Energía web page, accessed February 6, 2017, at http://www2.hidrocarburos.gob.bo/.
*Ministerio de Industria, Energía, y Minería [Uruguay], 2016a, Listado de autorizaciones de generación en el marco del Decreto No360-2002: Ministerio de Industria, Energía y Minería web page, accessed February 6, 2017, at http://www.dne.gub.uy/web/energia/-/listado-deautorizaciones-de-generacion-en-el-marco-del-decreto$\mathrm{n} \% \mathrm{C} 2 \% \mathrm{~B} 0360-2002$.

* Ministerio de Industria, Energía, y Minería [Uruguay], 2016b, Mapas energéticos-Actualización octubre 2016: Ministerio de Industria, Energía, y Minería web map, accessed March 16, 2017, at http://www.miem.gub.uy/ web/energia/publicaciones-y-estadisticas/planificacion-ybalance/-/asset_publisher/mf9rbTfIofs2/content/mapasenergeticos-actualizacion-octubre-2016; jsessionid $=064 \mathrm{~B} 9$ FCA65E79C023C11521EDB75C6A3?redirect=http\%3A \%2F\%2Fwww.miem.gub.uy\%2Fweb\%2Fenergia\%2Fpubl icaciones-y-estadisticas\%2Fplanificacion-y-balance $\% 3 \mathrm{Bjs}$ essionid\%3D064B9FCA65E79C023C11521EDB75C6A3 $\% 3 \mathrm{Fp} \_\mathrm{p} \_$id $\% 3 \mathrm{D} 101$ INSTANCE_mf9rbTfIofs $2 \% 26 \mathrm{p} \_$_ lifecycle $\% 3 \mathrm{D} 0 \% 26 \mathrm{p} \_\mathrm{p} \_$state $\% 3$ Dnormal $\% 26 \mathrm{p} \_\mathrm{p}$ mode $\% 3$ Dview\%26p_p_col_id\%3Dcolumn-1\%26p_p_col_ count $\% 3 \mathrm{D} 1$.

*Ministerio de Industria, Energía, y Minería [Uruguay], 2016c, Mapa petrolero: Administración Nacional de Combustibles, Alcoholes y Portland, Exploración y Producción de Hidrocarburos, Ministerio de Industria, Energía, y Minería web map, accessed February 6, 2017, at http://exploracionyproduccion.ancap.com.uy/.

*Ministerio de Obras Publicas y Comunicaciones, Viceministerio de Minas y Energia [Paraguay], 2016, Catasto hidrocarburos-MAPA: Ministerio de Obras Publicas y Comunicaciones, November 1, 2016, accessed February 6, 2017, at http://www.ssme.gov.py/vmme/images/ CatastroHidrocarburo/hidrocar_1-11-2016.png.

*Ministerio de Obras Públicas y Comunicaciones, Viceministerio de Minas y Energía [Paraguay], 2017, ElectricidadGeneración: Ministerio de Obras Públicas y Comunicaciones, Viceministerio de Minas y Energía web page, accessed February 6, 2017, at http://www.ssme.gov.py/vmme/index. php?option $=$ com_content\&view $=$ article $\&$ id $=1216 \&$.

*Ministry of Energy, Science and Technology, and Public Utilities [Belize], 2015, Belize petroleum contracts map: Ministry of Energy, Science and Technology, and Public Utilities, December 2015, accessed February 6, 2017, at http://estpu.gov.bz/index.php/geology-petroleum/gpdpetroleum-maps.

MMX Mineração e Metálicos S.A, [undated], Histórico e perfil corporativo [History and corporate profile]: MMX Mineração e Metálicos S.A., accessed June 2016 at http://www.mmx.com.br/show.aspx?idCanal= WN8uWmElUNSP1Zd5BsG5aQ= $=$. 
*Mobbs, P.M., 2015, The mineral industry of Guyana [advance release], in Area reports - International-Latin America and Canada: U.S. Geological Survey Minerals Yearbok 2013, v. III, p. 12.1-12.3, accessed April 2016 at https://minerals.usgs.gov/minerals/pubs/country/2013/ myb3-2013-gy.pdf.

*Mobbs, P.M., 2016a, The mineral industry of French Guiana [advance release], in Area reports - International-Latin America and Canada: U.S. Geological Survey Minerals Yearbok 2013, v. III, p.11.1-11.2, accessed April 2016 at https://minerals.usgs.gov/minerals/pubs/country/2013/ myb3-2013-fg.pdf.

*Mobbs, P.M., 2016b, The mineral industry of Suriname [advance release], in Area reports - International-Latin America and Canada: U.S. Geological Survey Minerals Yearbok 2013, v. III, p. 16.1-16.4, accessed April 2016 at https://minerals.usgs.gov/minerals/pubs/country/2013/ myb3-2013-ns.pdf.

Myers, Garfield, 2015, Alpart begins bauxite export from Port Kaiser: Jamaica Observer, September 9, accessed June 2016 at http://www.jamaicaobserver.com/news/Paulwell-hailsresumption-of-bauxite-export-from-Alpart_19227791.

*National Geospatial-Intelligence Agency (formerly U.S. National Imagery and Mapping Agency), 1992, Digital chart of the world [data as of March 2016]: National GeospatialIntelligence Agency dataset, accessed March 2016 at http://earth-info.nga.mil/publications/vmap0.html.

*National Geospatial-Intelligence Agency, 2017, Geopolitical Entities, Names, and Codes Standard: National GeospatialIntelligence Agency dataset, accessed April 9, 2017, at https://nsgreg.nga.mil/genc/discovery.

*National Geospatial-Intelligence Agency, Maritime Safety Office, 2013, World port index (22d ed.): National Geospatial-Intelligence Agency, Publication 150, accessed October 31, 2013, at http://msi.nga.mil/MSISiteContent/ StaticFiles/NAV_PUBS/WPI/Pub150bk.pdf. [Note: URL is only available for the most current version, the 26th edition as of 2017.]

Noble Group Ltd., 2016, Annual report 2015: Noble Group Ltd., 208 p., accessed June 2016 at http://www.thisisnoble. com/images/investors/financialInformation/annualReport/ ar2015.pdf.

Noranda Aluminum Holding Corp., 2015, 2014 annual report: Noranda Aluminum Holding Corp., 122 p., accessed June 2016 at http://media.corporate-ir.net/media_files/ IROL/22/220051/AR/Noranda_AR14.pdf.

*Offshore Post, 2015, Ecopetrol discovers hydrocarbons offshore Colombia: Offshore Post, August 1, 2015, accessed August 2016 at http://www.offshorepost.com/ecopetroldiscovers-hydrocarbons-offshore-colombia/.
Oil and Gas Year Ltd., The, 2015, 10 years of Camisea-The natural gas revolution in Peru: The Oil and Gas Year Ltd., February 24, 2015, accessed October 2016 at http://www. theoilandgasyear.com/articles/10-years-of-camisea-thenatural-gas-revolution-in-peru/.

Olson, D.W., 2016, Graphite (natural): U.S. Geological Survey Mineral Commodity Summaries 2016, p. 74-75, accessed April 24, 2017, at https://minerals.usgs.gov/minerals/pubs/ commodity/graphite/mcs-2016-graph.pdf.

* Organismo Supervisor de la Inversión en Energía y Minería [Peru], 2016, Centrales de Generación Eléctrica-En operación: Organismo Supervisor de la Inversion en Energia y Mineria, October 2016, accessed February 6, 2017, at http://www.osinergmin.gob.pe/seccion/centro_documental/ electricidad/Documentos/PROYECTOS\%20GFE/ Generaci\%C3\%B3n/2-EN-OPERACION.pdf.

Papp, J.F., 2014, Conflict minerals from the Democratic Republic of the Congo - Global tantalum processing plants, a critical part of the tantalum supply chain: U.S. Geological Survey Fact Sheet 2014-3122, 4 p., accessed April 24, 2017, at https://doi.org/10.3133/fs20143122.

Papp, J.F., 2016a, Niobium (columbium): U.S. Geological Survey Mineral Commodity Summaries 2015, p. 116-117, accessed April 24, 2017, at https://minerals.usgs.gov/ minerals/pubs/commodity/niobium/mcs-2016-niobi.pdf.

Papp, J.F., 2016b, Tantalum: U.S. Geological Survey Mineral Commodity Summaries 2015, p. 166-167, accessed April 24, 2017, at https://minerals.usgs.gov/minerals/pubs/ commodity/niobium/mcs-2016-tanta.pdf.

Patterson, S.H., Kurtz, H.F., Olson, J.C., and Neeley, C.L., 1986, World bauxite resources, chap. B of Geology and resources of aluminum: U.S. Geological Survey Professional Paper 1076-B, p. B1-B151, accessed June 6, 2016, at https://pubs.er.usgs.gov/publication/pp1076B.

*Perez, A.A., 2016, The mineral industry of Mexico [advance release], in Area reports-International-Latin America and Canada: U.S. Geological Survey Minerals Yearbok 2013, v. III, p. 14.1-14.11, accessed March 7, 2016, at https://minerals.usgs.gov/minerals/pubs/country/2013/ myb3-2013-mx.pdf.

*PeruPetro S.A., 2016, Block maps: PeruPetro S.A. web page, accessed June 18, 2016, at http://www.perupetro.com.pe/ wps/wcm/connect/perupetro/site-en/ImportantInformation/ Block\%20Maps/Block\%20Maps.

*Petróleos Mexicanos, 2011, Form 20-F for the fiscal year ended December 31, 2010: U.S. Securities and Exchange Commission, June 30, 2011, accessed October 2016 at https://www.sec.gov/Archives/edgar/ data/932782/000119312511178804/d20f.htm. 
*Petroleum Economist, 2015, Energy map of Trinidad and Tobago, 2015 edition: The National Gas Company of Trinidad and Tobago Ltd. web page, accessed August 2016 at http://ngc.co.tt/wp-content/uploads/pdf/publications/ energy-map-of-tnt-2015-ed.pdf.

Piñón, J.R., 2007, Cuba's future energy challenge [abs.]: Law of the Sea Institute Conference, Corpus Christi, Texas, March 22-24, 2007, accessed February 2015 at http://losi.tamucc.edu/Panels/Panelist\%20Abstracts/ Abstract\%20-\%20Jorge\%20Pinon.pdf.

Polyak, D.E., 2016a, Molybdenum: U.S. Geological Survey Mineral Commodity Summaries 2015, p. 112-113, accessed April 24, 2017, at https://minerals.usgs.gov/minerals/pubs/ commodity/molybdenum/mcs-2016-molyb.pdf.

Polyak, D.E., 2016b, Rhenium: U.S. Geological Survey Mineral Commodity Summaries 2015, p. 136-137, accessed April 24, 2017, at https://minerals.usgs.gov/minerals/pubs/ commodity/rhenium/mcs-2016-rheni.pdf.

Porto Sudeste do Brasil S.A., 2016, Porto Sudeste Terminal, Porto Sudeste do Brasil S.A. web site, accessed June 2016 at http://www.portosudeste.com/.

Queiroz Galvão, 2016, Santos Basin: Queiroz Galvão web page, accessed August 2016 at http://www.qgep.com.br/ static/enu/bacia-de-santos.asp?idioma=enu.

Rede Ferroviária Federal, S.A., 2007, Inventariança de extinta Rede Ferroviária Federal, S.A. - RFFSA [Inventory of the defunct Federal Railway Network S.A.]: Rede Ferroviária Federal, S.A. web page, accessed August 2016 at http:// www.rffsa.gov.br/.

*Rodriguez, M.R. (PETROBRAS), and S.B. Suslick (UNICAMP), 2009, An overview of Brazilian petroleum exploration lease auctions: Terrae, v. 6, no. 1, p. 6-20, accessed August 2016 at https://www.ige.unicamp.br/terrae/ V6/PDF-N6/T-a1i.pdf.

*Rosales, M.A.Á., 2015, Mexican energy reform transforms markets: Transmission and Distribution World, February 24, 2015, accessed August 2016 at http://tdworld.com/ renewables/mexican-energy-reform-transforms-markets- 0 .

*Salazar, Gabriel, and Rudnick, Hugh, 2008, Hydro power plants in Ecuador: A technical and economical analysis, in Conversion and delivery of electrical energy in the 21st century-Institute of Electrical and Electronics Engineers Power and Energy Society General Meeting, Pittsburgh, Pa., July 20-24, 2008: IEEE Xplore, p. 439-443, accessed February 6, 2017, at http://ieeexplore.ieee.org/abstract/ document $/ 4596897 /$ ?section=abstract.

Samarco Mineração S.A., 2016, About Samarco: Samarco Mineração S.A., accessed June 2016 at http://www.samarco. com/en/institucional/a-empresa/.
*Schenk, C.J., Viger, R.J., and Anderson, C.P., comps., 1997, Maps showing geology, oil and gas fields, and geological provinces of the South America region: U.S. Geological Survey Open-File Report 97-470D, accessed June 14, 2016, at http://pubs.usgs.gov/of/1997/ofr-97-470/OF97-470D/ sam06Gmap.html.

Schnebele, E.K., 2016, Iodine: U.S. Geological Survey Mineral Commodity Summaries 2015, p. 82-83, accessed April 24, 2017, at https://minerals.usgs.gov/minerals/pubs/ commodity/iodine/mcs-2016-iodin.pdf.

*Secretaría de Hidrocarburos [Ecuador; Secretariat of Hydrocarbons], 2016, Mapa de bloques petroleros [Map of oil blocks] Secretaría de Hidrocarburos web page, accessed June 18, 2016, at http://www.she.gob.ec/mapa-de-bloquespetroleros/.

Seth, Shobhit, 2016, South American economies reel from low Chinese demand: Investopedia, February 25, 2016, accessed August 2016 at http://www.investopedia.com/articles/ investing/022516/south-american-economies-reel-lowchinese-demand.asp.

Shedd, K.B., 2016, Cobalt: U.S. Geological Survey Mineral Commodity Summaries 2015, p. 52-53, accessed April 24, 2017, at https://minerals.usgs.gov/minerals/pubs/ commodity/cobalt/mcs-2016-cobal.pdf.

*Sipse, 2013, Escasa infraestructura encarece combustibles [Poor infrastructure makes fuel expensive]: Sipse, January 25, 2013, accessed October 2016 at http://sipse.com/ mexico/escasa-infraestructura-encarece-combustibles-12185. html.

Sistema de Información Ambiental de Colombia (SIAC) [Colombia], 2017, Catálogo de mapas-Ductos S. Hidrocarburos, original data from Autoridad Nacional de Licencias Ambientales (ANLA): Sistema de Información Ambiental de Colombia Web page, accessed March 15, 2017, available at http://www.siac.gov.co/Catalogo_mapas. html.

Society of Petroleum Engineers, 2001, Guidelines for the evaluation of petroleum reserves and resources-A supplement to the SPE/WPC petroleum reserves definitions and the SPE/WPC/AAPG petroleum resources definitions: Society of Petroleum Engineers, accessed April 4, 2017, at http://www.spe.org/industry/docs/GuidelinesEvaluation ReservesResources_2001.pdf.

Soto-Viruet, Yadira, 2015a, The mineral industries of the Islands of the Caribbean (Aruba, Dominican Republic, Jamaica, Trinidad and Tobago, and other islands) [advance release], in Area reports-International-Latin America and Canada: U.S. Geological Survey Minerals Yearbok 2013, v. III, p. 13.1-13.9, accessed March 7, 2016, at https://minerals.usgs.gov/minerals/pubs/country/2013/ myb3-2013-aa-bf-bb-dr-jm-td.pdf. 
*Soto-Viruet, Yadira, 2015b, The mineral industry of Peru [advance release], in Area reports - International-Latin America and Canada: U.S. Geological Survey Minerals Yearbok 2013, v. III, p. 16.1-16.14, accessed April 2016 at https://minerals.usgs.gov/minerals/pubs/country/2013/ myb3-2013-pe.pdf.

*Soto-Viruet, Yadira, 2016a, The mineral industry of Brazil [advance release], in Area reports - International-Latin America and Canada: U.S. Geological Survey Minerals Yearbok 2013, v. III, p. 4.1-4.19, accessed April 2016 at https://minerals.usgs.gov/minerals/pubs/country/2013/ myb3-2013-br.pdf.

*Soto-Viruet, Yadira, 2016b, The mineral industry of Cuba [advance release], in Area reports - International-Latin America and Canada: U.S. Geological Survey Minerals Yearbok 2014, v. III, p. 8.1-8.6, accessed March 7, 2016, at https://minerals.usgs.gov/minerals/pubs/country/2014/ myb3-2014-cu.pdf.

*Soto-Viruet, Yadira, 2016c, The mineral industry of Paraguay and Uruguay [advance release], in Area reports-International-Latin America and Canada: U.S. Geological Survey Minerals Yearbok 2014, v. III, p. 14.1-14.6, accessed March 7, 2016, at https://minerals.usgs.gov/minerals/pubs/ country/2014/myb3-2014-pa-uy.pdf.

*Soto-Viruet, Yadira, 2016d, The mineral industry of Venezuela [advance release], in Area reports-International-Latin America and Canada: U.S. Geological Survey Minerals Yearbok 2013, v. III, p. 18.1-18.9, accessed April 2016 at https://minerals.usgs.gov/minerals/pubs/country/2013/ myb3-2013-ve.pdf.

*Staatsolie Maatschappij Suriname N.V., 2017, About us-Company history: Staatsolie Maatschappij Suriname N.V. web page, accessed February 6, 2017, at http://www. staatsolie.com/en/about-us/history/.

*Statoil ASA, 2016, Statoil strengthens its position in Uruguay: Statoil ASA web page, February 15, 2016, accessed March 2016 at https://www.statoil.com/en/news/ strengthens-position-uruguay.html.

Tewalt, S.J., Kinney, S.A., and Merrill, M.D., 2008, GIS representation of coal-bearing areas in North, Central, and South America: U.S. Geological Survey Open-File Report 2008-1257, accessed November 30, 2016, at https://pubs.usgs.gov/of/2008/1257/.
*Tirado, Sergio, 2009, Características de los sistemas eléctricos venezolanos de generación y distribución de energía eléctrica [Characteristics of Venezuelan electric power generation and distribution systems]: Departamento de Electricidad [Venezuela], Sistemas de Potencia monograph, June 2009, accessed February 6, 2017, at http://www. monografias.com/trabajos73/sistemas-electronicosvenezolanos-energia-electrica/sistemas-electronicosvenezolanos-energia-electrica2.shtml.

Tolcin, A.C., 2016, Zinc: U.S. Geological Survey Mineral Commodity Summaries 2015, p. 192-193, accessed April 24, 2017, at https://minerals.usgs.gov/minerals/pubs/ commodity/zinc/mcs-2016-zinc.pdf.

Tuck, C.A., 2016, Iron ore: U.S. Geological Survey Mineral Commodity Summaries 2015, p. 90-91, accessed April 24, 2017, at https://minerals.usgs.gov/minerals/pubs/ commodity/iron_ore/mcs-2016-feore.pdf.

*Tullow Oil plc, 2016, New ventures-Jamaica, Jamaica map: Tullow Oil plc web page, accessed February 6, 2017, at via http://www.tullowoil.com/operations/new-ventures/jamaica.

*Unidad de Planeacion Minero Energetica and Agencia Nacional de Hidrocarburos [Colombia], 2015, Mapa de tierras ANH-2015-12-23: Agencia Nacional de Hidrocarburos dataset, accessed February 6, 2017, at http://data.guaviare. info/dataset/anh_2015_tierras_12_23 and http://upmeonline. maps.arcgis.com/apps/PublicInformation/index.html? appid=d3f4deb3cd404e8ea3f7f1e34b97b223.

*Unidad de Planeacion Minero Energetica [Colombia], 2015, Sistema de transmisión nacional actual: Unidad de Planceación Minero Energética, 1 p., accessed February 6, 2017, at http://sig.simec.gov.co/GeoPortal/images/pdf/ UPME_EN_TRANSMISI\%C3\%93N\%20PLAN\%20 2015-\%202029\%20\%20ACTUAL\%202015.pdf.

*Unidad de Planeación Minero Energética [Colombia; Energy and Mining Planning Unit], 2010, Plan de expansión de referencia, generación - transmissión 2010-2024 [Reference expansion plan, generation-transmission 2010-2024]: Unidad de Planeación Minero Energética, 299 p., accessed February 6, 2017, at http://www.upme.gov.co/Docs/ Plan_Expansion/2010/Plan_Expansion_2010-2024_ Definitivo.pdf.

United Company RUSAL plc, 2015, Annual report 2014Taming the challenge: United Company RUSAL plc, 278 p., accessed June 6, 2016, at http://www.rusal.ru/upload/iblock/ f9c/Rusal_AR_2014_Eng.pdf.

United Company RUSAL plc, 2016, Annual report 2015 - Driven by green power: United Company RUSAL plc, 270 p., accessed June 6, 2016, at http://www.rusal.ru/ upload/iblock/a77/3600065-t01 fnar\%20(e-03.13).pdf. 
*United Nations Office for the Coordination of Humanitarian Affairs (OCHA), Regional Office for Latin America (ROLA) and Instituto Geográfico Nacional [Peru], 2015, Industria de Peru: Humanitarian Data Exchange dataset, July 24, 2015, accessed February 6, 2017, at https://data. humdata.org/dataset/industria-de-peru.

Usinas Siderúrgicas de Minas Gerais S.A., 2009, Relatorio anual 2008 [Annual report 2008], Usinas Siderúrgicas de Minas Gerais S.A. 83 p., accessed June 2016 at http://ri.usiminas.com/enu/arquivos/relatorios/ relatorio_anual_2008.pdf.

Usinas Siderúrgicas de Minas Gerais S.A., 2011, Relatorio anual 2010 [Annual report 2010], Usinas Siderúrgicas de Minas Gerais S.A. 167 p., accessed June 2016 at http://ri.usiminas.com/enu/arquivos/relatorios/ AnnualReport2010.pdf.

*U.S. Department of Energy, National Renewable Energy Laboratory, 2015, Energy Transition Initiative-IslandsBelize: U.S. Department of Energy, National Renewable Energy Laboratory Fact Sheet DOE/GO-102015-4582, 4 p., accessed February 6, 2017, at http://www.nrel.gov/ docs/fy15osti/62707.pdf.

*U.S. Department of State, 2017, Africa and AmericasSimplified Large Scale International Boundaries (LSIB) Polygons: U.S. Department of State Humanitarian Information Unit, U.S. Department of State web page, accessed April 24, 2017, at https://data.humdata.org/dataset/ africaamericas-1sib-polygons-simplified-2017mar30.

U.S. Geological Survey, 2016, Mineral commodity summaries 2016: U.S. Geological Survey, 202 p., accessed April 2016 at https://minerals.usgs.gov/minerals/pubs/ mcs/2016/mcs2016.pdf.

U.S. Geological Survey and Corporación Venezolana de Guayana, Técnica Minera C.A., 1993, Geology and mineral resource assessment of the Venezuelan Guayana Shield: U.S. Geological Survey Bulletin 2062, 121 p., 8 pls., accessed April 24, 2017, at https://pubs.er.usgs.gov/ publication/b2062.

U.S. Geological Survey and Geological Survey of Guyana, 1976, Merumite-A complex assemblage of chromium minerals from Guyana: U.S. Geological Survey Professional Paper 887, 49 p., accessed April 25, 2017, at https://pubs. usgs.gov/pp/0887/report.pdf.

U.S. Geological Survey and Servicio Geológico de Bolivia, 1992, Geology and mineral resources of the Altiplano and Cordillera Occidental, Bolivia, with a section on Application of economic evaluations to deposit models, by D.I. Bleiwas and R.G. Christiansen: U.S. Geological Survey Bulletin 1975, 365 p., 8 pls. in pocket, accessed April 24, 2017, at https://pubs.er.usgs.gov/publication/b1975.
U.S. Geological Survey and Servicio Geologico Nacional de Colombia, 1969, Phosphate rock in Colombia-A preliminary report: U.S. Geological Survey Bulletin 1272-A, 86 p., 3 pls. in pocket, accessed April 25, 2017, at https://pubs. usgs.gov/bul/1272a/report.pdf.

U.S. Geological Survey, Dirección General de Geología, Minas y Hidrocarburos, and Universidad de Costa Rica, 1987, Mineral Resource Assessment of the Republic of Costa Rica [Evaluación de los Recursos Minerales de la República de Costa Rica]: U.S. Geological Survey Miscellaneous Investigations Series Map I-1865, 78 p., 10 pls., accessed April 25, 2017, at https://pubs.usgs.gov/ imap/1865/report.pdf.

*U.S. Geological Survey World Conventional Resources Assessment Team, 2013, Supporting data for the U.S. Geological Survey 2012 world assessment of undiscovered oil and gas resources: U.S. Geological Survey Digital Data Series DDS-69-FF, various pages, accessed May 2016 at https://pubs.usgs.gov/dds/dds-069/dds-069-ff/.

*U.S. Geological Survey World Energy Assessment Team, 2000, U.S. Geological Survey world petroleum assessment 2000_Description and results: U.S. Geological Survey Digital Data Series DDS-60, 4 CD-ROMs, accessed May 2016 at https://pubs.usgs.gov/dds/dds-060/.

Vale Overseas Ltd., 2002, Annual report 2001: Rio de Janeiro, Brazil, Vale S.A., 250 p., accessed June 6, 2016, at http:// www.vale.com/EN/investors/information-market/annualreports/20f/20FDocs/F2001i.pdf.

Vale S.A., 2012a, Vale: constructing a brand, chap. 10, Vale our history: Rio de Janeiro, Brazil, Vale S.A., p. 335-417, accessed April 9, 2017, at http://www.vale.com/EN/ aboutvale/book-our-history/Documents/livro/ valehistorybook10.pdf.

Vale S.A., 2012b, Vale: the creation of Companhia Vale do Rio Doce, chap. 2, Vale our history: Rio de Janeiro, Brazil, Vale S.A., p. 41-73, accessed April 9, 2017, at http://www. vale.com/EN/aboutvale/book-our-history/Documents/livro/ valehistorybook2.pdf.

Vale S.A., 2012c, Vale: mining in the First Republic, chap. 1, Vale our history: Rio de Janeiro, Brazil, Vale S.A., p. 17-40, accessed April 9, 2017, at http://www.vale.com/EN/ aboutvale/book-our-history/Documents/livro/ valehistorybook.pdf.

Vale S.A., 2016a, Form 20-F for the fiscal year ended December 31, 2015: U.S. Securities and Exchange Commission, accessed April 9, 2017, at http://www.vale.com/EN/ investors/information-market/annual-reports/20f/20FDocs/ Vale\%2020-F\%202015_i.PDF. 
Vale S.A., 2016b, Vale across the world: Vale S.A., accessed April 9, 2017, at http://www.vale.com/en/aboutvale/acrossworld/pages/default.aspx.

Viscidi, Lisa, Sucre, Carlos, and Karst, Sean, 2015, Natural gas market outlook-How Latin America and the Caribbean can benefit from the U.S. shale boom: The Inter-American Dialogue and the Inter-American Development Bank, 15 p., September 2015, accessed September 2016 at http://www. thedialogue.org/wp-content/uploads/2015/09/Natural-GasMarket-Outlook.pdf.

*Wacaster, Susan, 2015a, The mineral industry of Argentina [advance release], in Area reports_-International-Latin America and Canada: U.S. Geological Survey Minerals Yearbok 2013, v. III, p. 2.1-2.11, accessed April 2016 at https://minerals.usgs.gov/minerals/pubs/country/2013/ myb3-2013-ar.pdf.

*Wacaster, Susan, 2015b, The mineral industry of Chile [advance release], in Area reports-International-Latin America and Canada: U.S. Geological Survey Minerals Yearbok 2013, v. III, p. 7.1-7.19, accessed April 2016 at https://minerals.usgs.gov/minerals/pubs/country/2013/ myb3-2013-ci.pdf.

*Wacaster, Susan, 2015c, The mineral industry of Colombia [advance release], in Area reports-International-Latin America and Canada: U.S. Geological Survey Minerals Yearbok 2013, v. III, p. 8.1-8.8, accessed April 2016 at https://minerals.usgs.gov/minerals/pubs/country/2013/ myb3-2013-co.pdf.

*Wacaster, Susan, 2016a, The mineral industry of Bolivia [advance release], in Area reports-International-Latin America and Canada: U.S. Geological Survey Minerals Yearbok 2013, v. III, p. 3.1-3.12, accessed April 2016 at https://minerals.usgs.gov/minerals/pubs/country/2013/ myb3-2013-bl.pdf.

*Wacaster, Susan, 2016b, The mineral industry of Central America-Belize, Costa Rica, El Salvador, Guatemala, Honduras, Nicaragua, and Panama [advance release], in Area reports - International-Latin America and Canada: U.S. Geological Survey Minerals Yearbok 2014, v. III, p. 7.1-7.8, accessed March 7, 2016, at https://minerals.usgs. gov/minerals/pubs/country/2014/myb3-2014-bh-cs-es-gtho-nu-pm.pdf.

*Wacaster, Susan, 2016c, The mineral industry of Ecuador [advance release], in Area reports - International-Latin America and Canada: U.S. Geological Survey Minerals Yearbok 2014, v. III, p. 12.1-12.5, accessed March 7, 2016, at https://minerals.usgs.gov/minerals/pubs/country/2014/ myb3-2014-ec.pdf.
Wacaster, Susan, Baker, M.S., Soto-Viruet, Yadira, and Textoris, Steven, 2015, Recent trends in Cuba's mining and petroleum industries (ver. 1.1, April 9, 2015): U.S. Geological Survey Fact Sheet 2015-3032, 6 p., accessed March 2016 at https://doi.org/10.3133/fs20153032.

Wacaster, Susan, Soto-Viruet, Yadira, Perez, A.A., Anderson, S.T., Gurmendi, A.C., Mobbs, P.M., Wallace, G.J., and Wilburn, D.R., 2014, The mineral industries of Latin America and Canada, in Area reports - International-Latin America and Canada: U.S. Geological Survey Minerals Yearbook 2012, v. III, p. 1.1-1.26, accessed June 2016 at http://minerals.usgs.gov/minerals/pubs/country/2012/ myb3-sum-2012-latin-canada.pdf.

Wallace, R.M., 1976, Geological reconnaissance of some Uruguayan iron and manganese deposits in 1962: U.S. Geological Survey Open-File Report 76-466, 32 p., 1 pl., accessed April 25, 2017, at https://pubs.usgs.gov/ of/1976/0466/report.pdf.

*Weaver, J.N., and Wood, G.H., Jr., 1994, Coal map of South America: U.S. Geological Survey Coal Investigations Map C-145, accessed March 15, 2017, at https://pubs. er.usgs.gov/publication/coal145.

Wheeler, Brian, 2012, Hydro powers Latin America: Renewable Energy World, June 21, 2012, accessed Auguust 2016 at http://www.renewableenergyworld.com/articles/2012/06/ hydro-powers-latin-america.html.

Wilburn, D.R., Bleiwas, D.I., and Karl, N.A., 2016, Global stocks of selected mineral-based commodities: U.S. Geological Survey Scientific Investigations Report 2016-5152, 13 p., accessed March 24, 2016, at https://doi.org/10.3133/ sir20165152.

Wilburn, D.R., and Karl, N.A., 2016, Exploration review, in Annual review 2015: Mining Engineering, v. 68, no. 5, p. 30-51, accessed March 24, 2016, at https://minerals.usgs. gov/minerals/mflow/exploration-2015.pdf.

*Wilburn, D.R., Rapstine, T.D., and Lee, E.C., 2012, Exploration review, in Annual review 2011: Mining Engineering, v. 64, no. 5, p. 28-48, accessed March 24, 2016, at https:// minerals.usgs.gov/minerals/mflow/exploration-2011.pdf.

*Wilburn, D.R., and Stanley, K.A., 2013, Exploration review, in Annual review 2012: Mining Engineering, v. 65, no. 5, p. 22-42, accessed March 24, 2016, at https://minerals.usgs. gov/minerals/mflow/exploration-2012.pdf.

*Wilburn, D.R., and Stanley, K.A., 2014, Exploration review, in Annual review 2013: Mining Engineering, v. 66, no. 5, p. 18-39, accessed March 24, 2016, at https://minerals.usgs. gov/minerals/mflow/exploration-2013.pdf. 
*Wilburn, D.R., Stanley, K.A., and Karl, N.A., 2015, Exploration review, in Annual review 2014: Mining Engineering, v. 67, no. 5, p. 16-38, accessed March 24, 2016, at https:// minerals.usgs.gov/minerals/mflow/exploration-2014.pdf.

Wilmot, R.C., Sullivan, A.C., and Trought, M.E., 1959, Bauxite, in Metals and minerals: Bureau of Mines Minerals Yearbook 1958, v. I, p. 209-227, accessed June 6, 2016, at http:/digicoll.library.wisc.edu/cgi-bin/EcoNatRes/ EcoNatRes-idx?type=turn\&entity=EcoNatRes. MinYB1958v1.p0218\&id=EcoNatRes. MinYB1958v1\&isize $=$ M.
Yepez-García, R.A., Johnson, T.M., and Andrés, L.A., 2010, Meeting the electricity supply/demand balance in Latin America and the Caribbean: The World Bank, September 2010, 144 p., accessed April 24, 2017, at https:/www. esmap.org/sites/esmap.org/files/REPORT\%20LAC\%20 Electricity $\% 20$ Challenge $\% 20$ octubre $\% 202010 \% 20$ LESMAP\%20FINAL.pdf. 


\section{Appendixes}

Appendix 1. Data tables 1-1 through 1-7

Appendix 2. Case study 1: Iron ore mining and transportation infrastructure in Brazil's Iron Quadrangle

Appendix 3. Case study 2: Bauxite mining and alumina production in Jamaica 
Table 1-1. Global reserve estimates (2015) and mine production (2014-15) of nonfuel mineral commodities for countries of Latin America and the Caribbean, by commodity and country.

[From the USGS Mineral Commodity Summaries, 2016. CPPGP, country production as percent of global production; \%, percent; kg, kilogram; mt, metric ton; NA, not available. Data are rounded to no more than three significant digits. Units are thousand metric tons (tmt) of metal content or of the industrial mineral, unless otherwise specified]

\begin{tabular}{|c|c|c|c|c|c|c|c|c|c|c|c|c|c|}
\hline \multirow{3}{*}{ Country } & \multirow{3}{*}{$\begin{array}{l}\text { Mineral } \\
\text { commodity }\end{array}$} & \multicolumn{4}{|c|}{2015 reserve estimates } & \multicolumn{6}{|c|}{ Production data } & \multirow{3}{*}{ Unit } & \multirow{3}{*}{ Comments } \\
\hline & & \multirow[b]{2}{*}{$\begin{array}{l}\text { Reserve } \\
\text { estimate }\end{array}$} & \multirow[b]{2}{*}{$\begin{array}{l}\text { Global } \\
\text { rank }\end{array}$} & \multirow{2}{*}{$\begin{array}{l}\text { Global } \\
\text { reserve } \\
\text { estimate }\end{array}$} & \multirow{2}{*}{$\begin{array}{l}\text { Percent } \\
\text { of global } \\
\text { reserve } \\
\text { estimate }\end{array}$} & \multicolumn{3}{|c|}{2014} & \multicolumn{3}{|c|}{$\begin{array}{c}2015 \\
\text { (preliminary estimates) }\end{array}$} & & \\
\hline & & & & & & $\begin{array}{l}\text { Country } \\
\text { produc- } \\
\text { tion }\end{array}$ & $\begin{array}{l}\text { Global } \\
\text { produc- } \\
\text { tion }\end{array}$ & CPPGP & $\begin{array}{l}\text { Country } \\
\text { produc- } \\
\text { tion }\end{array}$ & $\begin{array}{l}\text { Global } \\
\text { produc- } \\
\text { tion }\end{array}$ & CPPGP & & \\
\hline Bolivia & Antimony & 310 & 3 & 2,000 & 16.0 & 5.5 & 158 & 3.5 & 5 & 150 & 3.3 & & $\begin{array}{l}2014 \text { production } \\
\text { estimated. }\end{array}$ \\
\hline Mexico & Barite & 7,000 & 8 & 380,000 & 2.0 & 420 & 8,250 & 5.1 & 220 & 7,460 & 2.9 & & \\
\hline Peru & Barite & NA & NA & 380,000 & NA & 106 & 8,250 & 1.3 & 100 & 7,460 & 1.0 & & \\
\hline Brazil & Bauxite & $2,600,000$ & 3 & $28,000,000$ & 9.3 & 34,800 & 245,000 & 14.2 & 35,000 & 274,000 & 13.0 & & \\
\hline Guyana & Bauxite & 850,000 & 7 & $28,000,000$ & 3.0 & 1,600 & 245,000 & 0.7 & 1,700 & 274,000 & 0.6 & $\begin{array}{l}\text { thousand metric } \\
\text { tons dry }\end{array}$ & \\
\hline Jamaica & Bauxite & $2,000,000$ & 5 & $28,000,000$ & 7.1 & 9,680 & 245,000 & 4.0 & 10,700 & 274,000 & 3.9 & $\begin{array}{l}\text { thousand metric } \\
\text { tons dry }\end{array}$ & \\
\hline Suriname & Bauxite & 580,000 & 10 & $28,000,000$ & 2.1 & 3,000 & 245,000 & 1.2 & 2,200 & 274,000 & 0.8 & $\begin{array}{l}\text { thousand metric } \\
\text { tons dry }\end{array}$ & \\
\hline Venezuela & Bauxite & 320,000 & 11 & $28,000,000$ & 1.1 & 1,500 & 245,000 & 0.6 & 1,500 & 274,000 & 0.5 & $\begin{array}{l}\text { thousand metric } \\
\text { tons dry }\end{array}$ & \\
\hline Bolivia & Bismuth & 10 & 4 & 370 & 3.0 & 0.01 & 13.6 & 0.1 & 0.010 & 13.6 & 0.1 & & \\
\hline Mexico & Bismuth & 10 & 5 & 370 & 3.0 & 0.948 & 13.6 & 7.0 & 0.7 & 13.6 & 5.1 & & \\
\hline Argentina & Boron & NA & NA & 380,000 & NA & 500 & 5,860 & 9.0 & 500 & 5,960 & 8.4 & $\begin{array}{l}\text { thousand metric } \\
\text { tons gross } \\
\text { weight }\end{array}$ & $\begin{array}{l}\text { Global production } \\
\text { totals exclude } \\
\text { U.S. production. }\end{array}$ \\
\hline Bolivia & Boron & NA & NA & 380,000 & NA & 15 & 5,860 & 0.3 & 15 & 5,960 & 0.3 & $\begin{array}{l}\text { thousand metric } \\
\text { tons gross } \\
\text { weight }\end{array}$ & $\begin{array}{l}\text { Global production } \\
\text { totals exclude } \\
\text { U.S. production. }\end{array}$ \\
\hline Chile & Boron & 35,000 & 4 & 380,000 & 9.0 & 580 & 5,860 & 10.0 & 580 & 5,960 & 9.7 & $\begin{array}{l}\text { thousand metric } \\
\text { tons gross } \\
\text { weight }\end{array}$ & $\begin{array}{l}\text { Global production } \\
\text { totals exclude } \\
\text { U.S. production. }\end{array}$ \\
\hline
\end{tabular}


Table 1-1. Global reserve estimates (2015) and mine production (2014-15) of nonfuel mineral commodities for countries of Latin America and the Caribbean, by commodity and country.-Continued

[From the USGS Mineral Commodity Summaries, 2016. CPPGP, country production as percent of global production; \%, percent; kg, kilogram; mt, metric ton; NA, not available. Data are rounded to no more than three significant digits. Units are thousand metric tons (tmt) of metal content or of the industrial mineral, unless otherwise specified]

\begin{tabular}{|c|c|c|c|c|c|c|c|c|c|c|c|c|c|}
\hline \multirow{3}{*}{ Country } & \multirow{3}{*}{$\begin{array}{l}\text { Mineral } \\
\text { commodity }\end{array}$} & \multicolumn{4}{|c|}{2015 reserve estimates } & \multicolumn{6}{|c|}{ Production data } & \multirow{3}{*}{ Unit } & \multirow{3}{*}{ Comments } \\
\hline & & \multirow{2}{*}{$\begin{array}{l}\text { Reserve } \\
\text { estimate }\end{array}$} & \multirow{2}{*}{$\begin{array}{l}\text { Global } \\
\text { rank }\end{array}$} & \multirow{2}{*}{$\begin{array}{l}\text { Global } \\
\text { reserve } \\
\text { estimate }\end{array}$} & \multirow{2}{*}{$\begin{array}{l}\text { Percent } \\
\text { of global } \\
\text { reserve } \\
\text { estimate }\end{array}$} & \multicolumn{3}{|c|}{2014} & \multicolumn{3}{|c|}{$\begin{array}{c}2015 \\
\text { (preliminary estimates) }\end{array}$} & & \\
\hline & & & & & & $\begin{array}{l}\text { Country } \\
\text { produc- } \\
\text { tion }\end{array}$ & $\begin{array}{l}\text { Global } \\
\text { produc- } \\
\text { tion }\end{array}$ & CPPGP & $\begin{array}{l}\text { Country } \\
\text { produc- } \\
\text { tion }\end{array}$ & $\begin{array}{l}\text { Global } \\
\text { produc- } \\
\text { tion }\end{array}$ & CPPGP & & \\
\hline Peru & Boron & 4,000 & 6 & 380,000 & 1.0 & 225 & 5,860 & 3.8 & 225 & 5,960 & 3.8 & $\begin{array}{l}\text { thousand metric } \\
\text { tons gross } \\
\text { weight }\end{array}$ & $\begin{array}{l}\text { Global production } \\
\text { totals exclude } \\
\text { U.S. production. }\end{array}$ \\
\hline Mexico & Cadmium & NA & NA & NA & NA & 1.41 & 24.2 & 5.8 & 1.46 & 24.2 & 6.0 & & \\
\hline Peru & Cadmium & NA & NA & NA & NA & 0.769 & 24.2 & 3.2 & 0.75 & 24.2 & 3.1 & & \\
\hline Brazil & Cobalt & 78 & 11 & 7,100 & 1.0 & 2.6 & 123 & 2.1 & 2.6 & 124 & 2.1 & & \\
\hline Cuba & Cobalt & 500 & 3 & 7,100 & 7.0 & 3.7 & 123 & 3.0 & 4.2 & 124 & 3.4 & & \\
\hline Chile & Copper & 210,000 & 1 & 720,000 & 29.0 & 5,750 & 18,500 & 31.0 & 5,700 & 18,700 & 31.0 & & \\
\hline Mexico & Copper & 46,000 & 4 & 720,000 & 6.4 & 515 & 18,500 & 2.8 & 550 & 18,700 & 3.0 & & \\
\hline Peru & Copper & 82,000 & 3 & 720,000 & 11.0 & 1,380 & 18,500 & 7.5 & 1,600 & 18,700 & 8.6 & & \\
\hline Mexico & Fluorspar & 32,000 & 2 & 250,000 & 13.0 & 1,110 & 6,390 & 17.4 & 1,110 & 6,250 & 17.8 & & $\begin{array}{l}\text { Reserves measured } \\
\text { as } 100 \% \text { calcium } \\
\text { fluoride. }\end{array}$ \\
\hline Brazil & Gold & 2,400 & 7 & 56,000 & 4.3 & 80 & 2,990 & 2.7 & 80 & 3,000 & 3.0 & $\begin{array}{l}\text { metric tons of } \\
\text { gold content }\end{array}$ & \\
\hline Mexico & Gold & 1,400 & 11 & 56,000 & 2.5 & 118 & 2,990 & 3.9 & 120 & 3,000 & 4.0 & $\begin{array}{l}\text { metric tons of } \\
\text { gold content }\end{array}$ & \\
\hline Peru & Gold & 2,800 & 6 & 56,000 & 5.0 & 140 & 2,990 & 4.7 & 150 & 3,000 & 5.0 & $\begin{array}{l}\text { metric tons of } \\
\text { gold content }\end{array}$ & \\
\hline Brazil & Graphite & 72,000 & 2 & 230,000 & 31.0 & 80 & 1,190 & 7.0 & 80 & 1,190 & 7.0 & & \\
\hline Mexico & Graphite & 3,100 & 5 & 230,000 & 1.0 & 22 & 1,190 & 2.0 & 22 & 1,190 & 2.0 & & \\
\hline Chile & Iodine & 1,800 & 2 & 75,000 & 2.4 & 20 & 30.3 & 66.0 & 20 & 30.3 & 66.0 & & $\begin{array}{l}\text { Measured in } \\
\text { elemental iodine. }\end{array}$ \\
\hline Brazil & Iron ore & 23,000 & 3 & 190,000 & 12.0 & 411 & 3,420 & 12.0 & 428 & 3,320 & 13.0 & $\begin{array}{l}\text { million metric } \\
\text { tons gross } \\
\text { weight of } \\
\text { crude ore }\end{array}$ & $\begin{array}{l}\text { Reserves are of } \\
\text { crude ore. Iron } \\
\text { content of re- } \\
\text { serves for Brazil } \\
\text { is } 12 \text { billion } \\
\text { metric tons. }\end{array}$ \\
\hline
\end{tabular}


Table 1-1. Global reserve estimates (2015) and mine production (2014-15) of nonfuel mineral commodities for countries of Latin America and the Caribbean, by commodity and country.-Continued

[From the USGS Mineral Commodity Summaries, 2016. CPPGP, country production as percent of global production; \%, percent; kg, kilogram; mt, metric ton; NA, not available. Data are rounded to no more than three significant digits. Units are thousand metric tons (tmt) of metal content or of the industrial mineral, unless otherwise specified]

\begin{tabular}{|c|c|c|c|c|c|c|c|c|c|c|c|c|c|}
\hline \multirow{3}{*}{ Country } & \multirow{3}{*}{$\begin{array}{c}\text { Mineral } \\
\text { commodity }\end{array}$} & \multicolumn{4}{|c|}{2015 reserve estimates } & \multicolumn{6}{|c|}{ Production data } & \multirow{3}{*}{ Unit } & \multirow{3}{*}{ Comments } \\
\hline & & \multirow{2}{*}{$\begin{array}{l}\text { Reserve } \\
\text { estimate }\end{array}$} & \multirow{2}{*}{$\begin{array}{l}\text { Global } \\
\text { rank }\end{array}$} & \multirow{2}{*}{$\begin{array}{l}\text { Global } \\
\text { reserve } \\
\text { estimate }\end{array}$} & \multirow{2}{*}{$\begin{array}{c}\text { Percent } \\
\text { of global } \\
\text { reserve } \\
\text { estimate }\end{array}$} & \multicolumn{3}{|c|}{2014} & \multicolumn{3}{|c|}{$\begin{array}{c}2015 \\
\text { (preliminary estimates) }\end{array}$} & & \\
\hline & & & & & & $\begin{array}{l}\text { Country } \\
\text { produc- } \\
\text { tion }\end{array}$ & $\begin{array}{l}\text { Global } \\
\text { produc- } \\
\text { tion }\end{array}$ & CPPGP & $\begin{array}{c}\text { Country } \\
\text { produc- } \\
\text { tion }\end{array}$ & $\begin{array}{l}\text { Global } \\
\text { produc- } \\
\text { tion }\end{array}$ & CPPGP & & \\
\hline Bolivia & Lead & 1,600 & 9 & 89,000 & 1.8 & 94 & 4,870 & 1.9 & 82 & 4,710 & 1.7 & & \\
\hline Mexico & Lead & 5,600 & 5 & 89,000 & 6.3 & 250 & 4,870 & 5.0 & 240 & 4,710 & 5.0 & & \\
\hline Peru & Lead & 6,700 & 4 & 89,000 & 7.5 & 278 & 4,870 & 5.7 & 300 & 4,710 & 6.0 & & \\
\hline Argentina & Lithium & 2 & 3 & 14 & 14.0 & 3.2 & 31.7 & 10.0 & 3.8 & 32.5 & 12.0 & & \\
\hline Brazil & Lithium & 0.048 & 6 & 14 & 0.3 & 0.16 & 31.7 & 0.5 & 0.16 & 32.5 & 0.5 & & \\
\hline Chile & Lithium & 7.5 & 1 & 14 & 54.0 & 11.5 & 31.7 & 36.0 & 11.7 & 32.5 & 36.0 & & \\
\hline Brazil & $\begin{array}{l}\text { Magnesium } \\
\text { compounds }\end{array}$ & 86,000 & 7 & $2,400,000$ & 3.6 & 175 & 8,420 & 2.0 & 175 & 8,300 & 2.0 & & \\
\hline Brazil & Manganese & 50,000 & 5 & 620,000 & 8.1 & 1,040 & 17,800 & 6.0 & 1,000 & 18,000 & 6.0 & $\begin{array}{l}\text { thousand metric } \\
\text { tons gross } \\
\text { weight }\end{array}$ & \\
\hline Mexico & Manganese & 5,000 & 9 & 620,000 & 0.8 & 236 & 17,800 & 1.0 & 240 & 18,000 & 1.3 & $\begin{array}{l}\text { thousand metric } \\
\text { tons gross } \\
\text { weight }\end{array}$ & \\
\hline Chile & Molybdenum & 1,800 & 3 & 11,000 & 16.0 & 48.8 & 281 & 17.0 & 49 & 267 & 18.0 & & \\
\hline Mexico & Molybdenum & 130 & 11 & 11,000 & 1.0 & 14.4 & 281 & 5.0 & 13 & 267 & 4.9 & & \\
\hline Peru & Molybdenum & 450 & 4 & 11,000 & 4.0 & 17 & 281 & 6.0 & 18.1 & 267 & 6.8 & & \\
\hline Brazil & Nickel & 10,000 & 2 & 79,000 & 13.0 & 102 & 2,450 & 4.2 & 110 & 2,530 & 4.0 & & \\
\hline Colombia & Nickel & 1,100 & 13 & 79,000 & 1.4 & 81 & $2,450.0$ & 3.3 & 73 & 2,530 & 3.0 & & \\
\hline Cuba & Nickel & 5,500 & 5 & 79,000 & 7.0 & 50.4 & $2,450.0$ & 2.0 & 57 & 2,530 & 2.0 & & \\
\hline $\begin{array}{l}\text { Guate- } \\
\text { mala }\end{array}$ & Nickel & 1,800 & 11 & 79,000 & 2.3 & 38.4 & $2,450.0$ & 1.6 & 50 & 2,530 & 2.0 & & \\
\hline Brazil & $\begin{array}{l}\text { Niobium (co- } \\
\text { lumbium) }\end{array}$ & 4,100 & 1 & 4,300 & 95.0 & 50 & 55.9 & 89.0 & 50 & 56 & 89.0 & & $\begin{array}{l}\text { Global reserves } \\
\text { greater than } \\
4,300,000 \text { metric } \\
\text { tons of niobium } \\
\text { content. }\end{array}$ \\
\hline Brazil & $\begin{array}{l}\text { Phosphate } \\
\text { rock }\end{array}$ & 320,000 & 14 & $69,000,000$ & 0.5 & 6,040 & 218,000 & 3.0 & 6,700 & 223,000 & 3.0 & & \\
\hline
\end{tabular}


Table 1-1. Global reserve estimates (2015) and mine production (2014-15) of nonfuel mineral commodities for countries of Latin America and the Caribbean, by commodity and country.-Continued

[From the USGS Mineral Commodity Summaries, 2016. CPPGP, country production as percent of global production; \%, percent; kg, kilogram; mt, metric ton; NA, not available. Data are rounded to no more than three significant digits. Units are thousand metric tons (tmt) of metal content or of the industrial mineral, unless otherwise specified]

\begin{tabular}{|c|c|c|c|c|c|c|c|c|c|c|c|c|c|}
\hline \multirow{3}{*}{ Country } & \multirow{3}{*}{$\begin{array}{l}\text { Mineral } \\
\text { commodity }\end{array}$} & \multicolumn{4}{|c|}{2015 reserve estimates } & \multicolumn{6}{|c|}{ Production data } & \multirow{3}{*}{ Unit } & \multirow{3}{*}{ Comments } \\
\hline & & \multirow{2}{*}{$\begin{array}{l}\text { Reserve } \\
\text { estimate }\end{array}$} & \multirow{2}{*}{$\begin{array}{l}\text { Global } \\
\text { rank }\end{array}$} & \multirow{2}{*}{$\begin{array}{l}\text { Global } \\
\text { reserve } \\
\text { estimate }\end{array}$} & \multirow{2}{*}{$\begin{array}{c}\text { Percent } \\
\text { of global } \\
\text { reserve } \\
\text { estimate }\end{array}$} & \multicolumn{3}{|c|}{2014} & \multicolumn{3}{|c|}{$\begin{array}{c}2015 \\
\text { (preliminary estimates) }\end{array}$} & & \\
\hline & & & & & & $\begin{array}{l}\text { Country } \\
\text { produc- } \\
\text { tion }\end{array}$ & $\begin{array}{l}\text { Global } \\
\text { produc- } \\
\text { tion }\end{array}$ & CPPGP & $\begin{array}{l}\text { Country } \\
\text { produc- } \\
\text { tion }\end{array}$ & $\begin{array}{l}\text { Global } \\
\text { produc- } \\
\text { tion }\end{array}$ & CPPGP & & \\
\hline Mexico & $\begin{array}{l}\text { Phosphate } \\
\text { rock }\end{array}$ & 30,000 & 20 & $69,000,000$ & 0.0 & 1,700 & 218,000 & 0.8 & 1,700 & 223,000 & 0.8 & & \\
\hline Peru & $\begin{array}{l}\text { Phosphate } \\
\text { rock }\end{array}$ & 820,000 & 12 & $69,000,000$ & 1.2 & 3,800 & 218,000 & 1.7 & 4,000 & 223,000 & 2.0 & & \\
\hline Brazil & Potash & 13,000 & 13 & $3,700,000$ & 0.4 & 311 & 38,800 & 0.8 & 311 & 38,800 & 0.8 & $\begin{array}{l}\text { tmt of } \mathrm{K}_{2} \mathrm{O} \\
\text { equivalent }\end{array}$ & $\begin{array}{l}\text { Reserves of recov- } \\
\text { erable ore equal } \\
300 \text { million } \\
\text { metric tons. }\end{array}$ \\
\hline Chile & Potash & 150,000 & 8 & $3,700,000$ & 4.0 & 1,200 & 38,800 & 3.0 & 1,200 & 38,800 & 3.0 & $\begin{array}{l}\text { tmt of } \mathrm{K}_{2} \mathrm{O} \\
\text { equivalent }\end{array}$ & $\begin{array}{l}\text { Reserves of } \\
\text { recoverable ore } \\
\text { not available for } \\
\text { Chile. }\end{array}$ \\
\hline Brazil & Rare earths & 22,000 & 2 & 130,000 & 17.0 & NA & 123 & NA & NA & 124 & NA & $\begin{array}{l}\text { tmt of rare- } \\
\text { earth oxide } \\
\text { (REO) } \\
\text { equivalent }\end{array}$ & \\
\hline Chile & Rhenium & $1,300,000$ & 1 & $2,500,000$ & 52.0 & 25,000 & 44,700 & 56.0 & 26,000 & 46,000 & 57.0 & $\begin{array}{l}\mathrm{kg} \text { of rhenium } \\
\text { content }\end{array}$ & $\begin{array}{l}\text { Estimated amount } \\
\text { recovered with } \\
\text { copper and } \\
\text { molybdenum } \\
\text { production; ex- } \\
\text { cludes secondary } \\
\text { rhenium. }\end{array}$ \\
\hline Peru & Rhenium & 45,000 & 5 & $2,500,000$ & 2.0 & NA & 44,700 & NA & NA & 46,000 & NA & $\begin{array}{l}\mathrm{kg} \text { of rhenium } \\
\text { content }\end{array}$ & $\begin{array}{l}\text { Estimated amount } \\
\text { recovered with } \\
\text { copper and } \\
\text { molybdenum } \\
\text { production; ex- } \\
\text { cludes secondary } \\
\text { rhenium. }\end{array}$ \\
\hline
\end{tabular}


Table 1-1. Global reserve estimates (2015) and mine production (2014-15) of nonfuel mineral commodities for countries of Latin America and the Caribbean, by commodity and country.-Continued

[From the USGS Mineral Commodity Summaries, 2016. CPPGP, country production as percent of global production; \%, percent; kg, kilogram; mt, metric ton; NA, not available. Data are rounded to no more than three significant digits. Units are thousand metric tons (tmt) of metal content or of the industrial mineral, unless otherwise specified]

\begin{tabular}{|c|c|c|c|c|c|c|c|c|c|c|c|c|c|}
\hline \multirow{3}{*}{ Country } & \multirow{3}{*}{$\begin{array}{l}\text { Mineral } \\
\text { commodity }\end{array}$} & \multicolumn{4}{|c|}{2015 reserve estimates } & \multicolumn{6}{|c|}{ Production data } & \multirow{3}{*}{ Unit } & \multirow{3}{*}{ Comments } \\
\hline & & \multirow{2}{*}{$\begin{array}{l}\text { Reserve } \\
\text { estimate }\end{array}$} & \multirow{2}{*}{$\begin{array}{l}\text { Global } \\
\text { rank }\end{array}$} & \multirow{2}{*}{$\begin{array}{l}\text { Global } \\
\text { reserve } \\
\text { estimate }\end{array}$} & \multirow{2}{*}{$\begin{array}{l}\text { Percent } \\
\text { of global } \\
\text { reserve } \\
\text { estimate }\end{array}$} & \multicolumn{3}{|c|}{2014} & \multicolumn{3}{|c|}{$\begin{array}{c}2015 \\
\text { (preliminary estimates) }\end{array}$} & & \\
\hline & & & & & & $\begin{array}{l}\text { Country } \\
\text { produc- } \\
\text { tion }\end{array}$ & $\begin{array}{l}\text { Global } \\
\text { produc- } \\
\text { tion }\end{array}$ & CPPGP & $\begin{array}{l}\text { Country } \\
\text { produc- } \\
\text { tion }\end{array}$ & $\begin{array}{l}\text { Global } \\
\text { produc- } \\
\text { tion }\end{array}$ & CPPGP & & \\
\hline Chile & Selenium & 25,000 & 2 & 120,000 & 21.0 & 41 & NA & NA & 50 & NA & NA & $\begin{array}{l}\text { mt of selenium } \\
\text { content }\end{array}$ & $\begin{array}{l}\text { Selenium content } \\
\text { of refineray } \\
\text { production. }\end{array}$ \\
\hline Peru & Selenium & 13,000 & 4 & 120,000 & 11.0 & 49 & NA & NA & 50 & NA & NA & $\begin{array}{l}\text { mt of selenium } \\
\text { content }\end{array}$ & $\begin{array}{l}\text { Selenium content } \\
\text { of refineray } \\
\text { production. }\end{array}$ \\
\hline Bolivia & Silver & 22 & 8 & 570 & 4.0 & 1.34 & 26.8 & 5.0 & 1.3 & 27.3 & 5.0 & & \\
\hline Chile & Silver & 77 & 4 & 570 & 14.0 & 1.57 & 26.8 & 6.0 & 1.6 & 27.3 & 6.0 & & \\
\hline Mexico & Silver & 37 & 6 & 570 & 6.5 & 5 & 26.8 & 19.0 & 5.4 & 27.3 & 20.0 & & \\
\hline Peru & Silver & 120 & 1 & 570 & 21.0 & 3.78 & 26.8 & 14.0 & 3.8 & 27.3 & 14.0 & & \\
\hline Brazil & Tantalum & 36,000 & 2 & 100,000 & 36.0 & 150 & 1,200 & 13.0 & 150 & 1,200 & 13.0 & $\begin{array}{l}\text { mt of tantalum } \\
\text { content }\end{array}$ & $\begin{array}{l}\text { Global reserves } \\
\text { greater than } \\
100,000 \mathrm{mt} \text { of } \\
\text { tantalum content. }\end{array}$ \\
\hline Peru & Tellurium & 3,600 & 1 & 25,000 & 14.0 & NA & NA & NA & NA & NA & NA & $\begin{array}{l}\text { mt of tellurium } \\
\text { content }\end{array}$ & $\begin{array}{l}\text { Tellurium content } \\
\text { of refinery } \\
\text { production. }\end{array}$ \\
\hline Bolivia & Tin & 400 & 4 & 4,800 & 8.0 & 19.9 & 286 & 7.0 & 20 & 294 & 7.0 & & \\
\hline Brazil & Tin & 700 & 3 & 4,800 & 15.0 & 14.7 & 286 & 5.0 & 17 & 294 & 6.0 & & \\
\hline Peru & Tin & 130 & 9 & 4,800 & 3.0 & 23.1 & 286 & 8.0 & 22.5 & 294 & 8.0 & & \\
\hline Brazil & $\begin{array}{l}\text { Titanium } \\
\text { mineral } \\
\text { concentrates } \\
\text { (Ilmenite) }\end{array}$ & 43,000 & 6 & 740,000 & 6.0 & 100 & 5,570 & 2.0 & 100 & 5,610 & 2.0 & $\begin{array}{l}\text { tmt of con- } \\
\text { tained } \mathrm{TiO}_{2}\end{array}$ & \\
\hline Bolivia & Zinc & 4,600 & 8 & 200,000 & 2.0 & 449 & 13,300 & 3.0 & 430 & 13,400 & 3.0 & & \\
\hline Mexico & Zinc & 15,000 & 4 & 200,000 & 8.0 & 660 & 13,300 & 5.0 & 660 & 13,400 & 5.0 & & \\
\hline Peru & Zinc & 25,000 & 3 & 200,000 & 13.0 & 1,320 & 13,300 & 10.0 & 1,370 & 13,400 & 10.0 & & \\
\hline
\end{tabular}


Table 1-2. Cumulative production and recoverable proven plus probable resources of conventional hydrocarbon resources from gas-only fields, by country within Latin America and the Caribbean.

[Data derived from IHS International Exploration and Production Database; used with permission from IHS Global, Inc.' (IHS Global Inc., 2016). Excludes extra-heavy crude and unconventional resources (coalbed methane, shale gas, tight gas, shale oil, and tight oil). Data for oil and condensate in million cubic meters (MCM); data for gas in billion cubic meters (BCM). LT1, less than one unit; NA, not available; RPP, recoverable proven plus probable resources; $\mathrm{W}$, data withheld to conceal proprietary data. Data are rounded to no more than three significant digits; may not add to totals shown. Data are unrounded for grand total of number of fields]

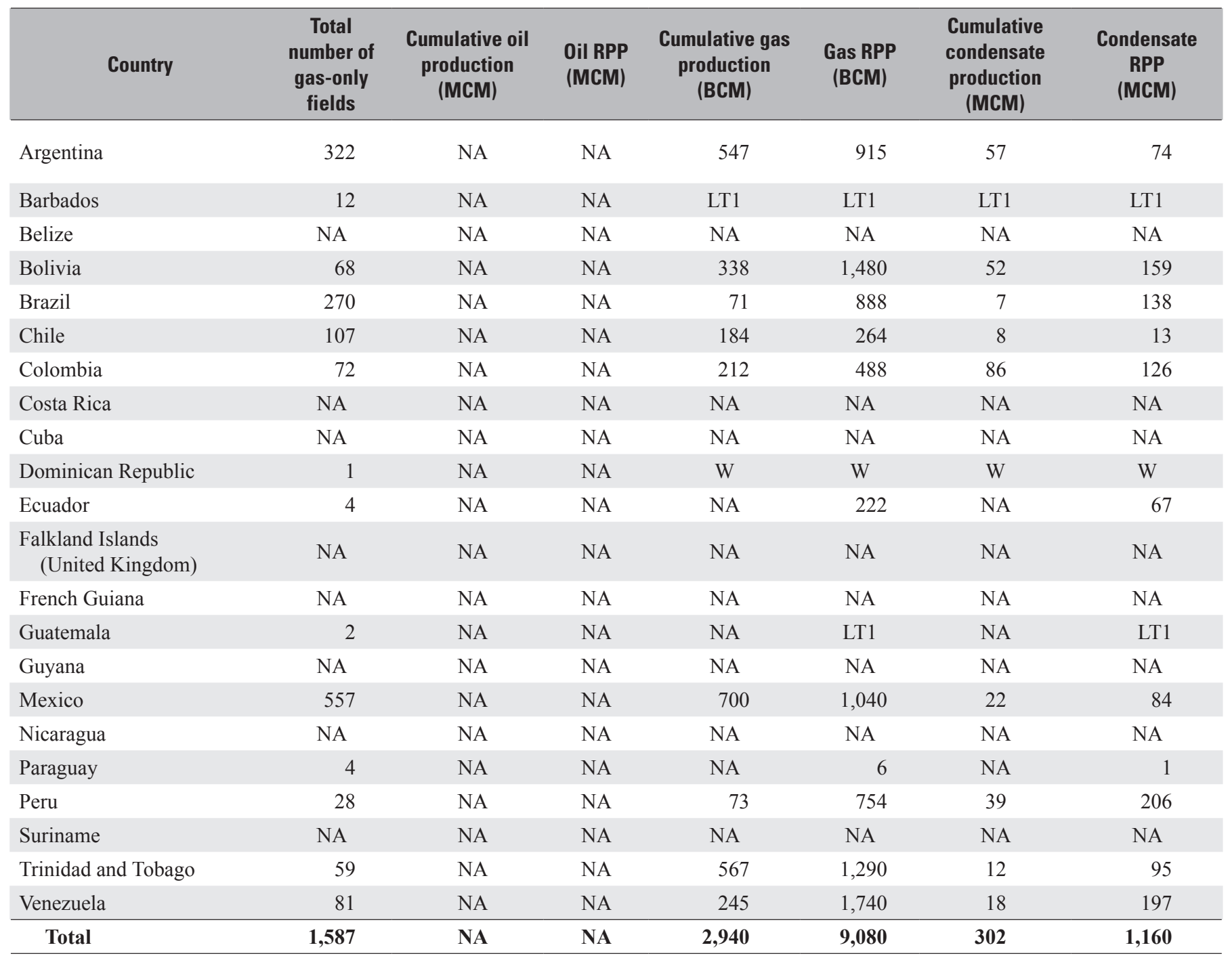

${ }^{1}$ In July 2016, the parent company of IHS Global, IHS Inc., merged with Markit Ltd. to become IHS Markit. These data were accessed and acquired in early 2016 , prior to the finalization of this merger. 
Table 1-3. Cumulative production and recoverable proven plus probable resources of extra-heavy crude resources from oil fields, by country within Latin America and the Caribbean.

[Data derived from IHS International Exploration and Production Database; used with permission from IHS Global, Inc. ${ }^{1}$ (IHS Global Inc., 2016). Excludes conventional and unconventional resources (coalbed methane, shale gas, tight gas, shale oil, and tight oil). Data for oil and condensate in million cubic meters (MCM); data for gas in billion cubic meters (BCM). LT1, less than one unit; NA, not available; RPP, recoverable proven plus probable resources; W, data withheld to conceal proprietary data. Data are rounded to no more than three significant digits; may not add to totals shown. Data are unrounded for grand total of number of fields]

\begin{tabular}{|c|c|c|c|c|c|c|c|}
\hline Country & $\begin{array}{c}\text { Total } \\
\text { number of } \\
\text { oil fields }\end{array}$ & $\begin{array}{l}\text { Cumulative oil } \\
\text { production } \\
\text { (MCM) }\end{array}$ & $\begin{array}{l}\text { Oil RPP } \\
\text { (MCM) }\end{array}$ & $\begin{array}{l}\text { Cumulative gas } \\
\text { production } \\
\text { (BCM) }\end{array}$ & $\begin{array}{c}\text { Gas RPP } \\
\text { (BCM) }\end{array}$ & $\begin{array}{c}\text { Cumulative } \\
\text { condensate } \\
\text { production } \\
\text { (MCM) }\end{array}$ & $\begin{array}{c}\text { Condensate } \\
\text { RPP } \\
\text { (MCM) }\end{array}$ \\
\hline Colombia & 6 & 2 & 65 & LT1 & LT1 & NA & NA \\
\hline Ecuador & 1 & NA & $\mathrm{W}$ & NA & $\mathrm{W}$ & NA & NA \\
\hline Trinidad and Tobago & 1 & NA & $\mathrm{W}$ & NA & $\mathrm{W}$ & NA & NA \\
\hline Venezuela & 33 & 566 & 43,000 & 17 & 627 & NA & NA \\
\hline Total & 60 & 568 & 43,200 & 17 & 634 & NA & NA \\
\hline
\end{tabular}

${ }^{1}$ In July 2016, the parent company of IHS Global, IHS Inc., merged with Markit Ltd. to become IHS Markit. These data were accessed and acquired in early 2016, prior to the finalization of this merger.

Table 1-4. Cumulative production and recoverable proven plus probable resources of unconventional hydrocarbon resources from oil fields, by country within Latin America and the Caribbean.

[Data derived from IHS International Exploration and Production Database; used with permission from IHS Global, Inc. ${ }^{1}$ (IHS Global Inc., 2016). Excludes conventional and extra-heavy crude resources. Data for oil and condensate in million cubic meters (MCM); data for gas in billion cubic meters (BCM). LT1, less than one unit; NA, not available; RPP, recoverable proven plus probable resources; W, data withheld to conceal proprietary data. Data are rounded to no more than three significant digits; may not add to totals shown. Data are unrounded for grand total of number of fields]

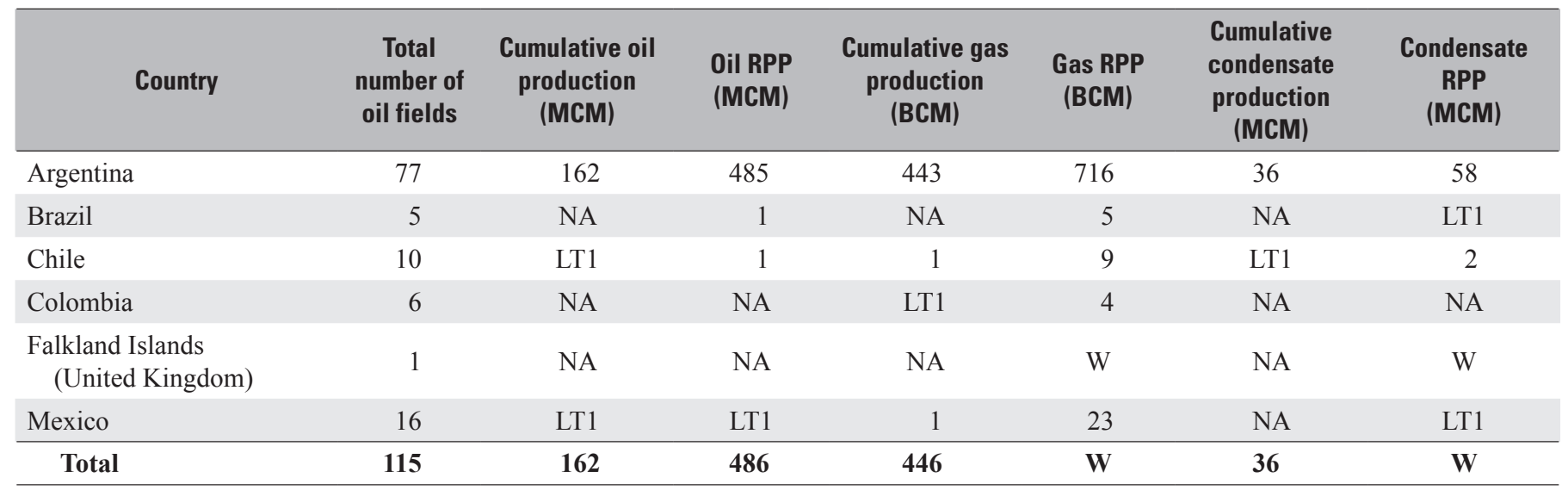

${ }^{1}$ In July 2016, the parent company of IHS Global, IHS Inc., merged with Markit Ltd. to become IHS Markit. These data were accessed and acquired in early 2016 , prior to the finalization of this merger. 
Table 1-5. Cumulative production and recoverable proven plus probable resources of conventional hydrocarbon resources from gas-only fields, by petroleum province within Latin America and the Caribbean.

[Data derived from IHS International Exploration and Production Database; used with permission from IHS Global, Inc. ${ }^{1}$ (IHS Global Inc., 2016). Excludes extra-heavy crude and unconventional resources (coalbed methane, shale gas, tight gas, shale oil, and tight oil). Data for oil and condensate in million cubic meters (MCM); data for gas in billion cubic meters (BCM). LT1, less than one unit; NA, not available; RPP, recoverable proven plus probable resources; W, data withheld to conceal proprietary data. Data are rounded to no more than three significant digits; may not add to totals shown. Data are unrounded for grand total of number of fields]

\begin{tabular}{|c|c|c|c|c|c|c|c|c|}
\hline $\begin{array}{l}\text { USGS } \\
\text { petroleum } \\
\text { province } \\
\text { code }\end{array}$ & $\begin{array}{l}\text { USGS petroleum } \\
\text { province name }\end{array}$ & $\begin{array}{c}\text { Total } \\
\text { number of } \\
\text { gas-only } \\
\text { fields }\end{array}$ & $\begin{array}{l}\text { Cumulative oil } \\
\text { production } \\
\text { (MCM) }\end{array}$ & $\begin{array}{l}\text { Oil RPP } \\
\text { (MCM) }\end{array}$ & $\begin{array}{l}\text { Cumulative gas } \\
\text { production } \\
\text { (BCM) }\end{array}$ & $\begin{array}{l}\text { Gas RPP } \\
\text { (BCM) }\end{array}$ & $\begin{array}{c}\text { Cumulative } \\
\text { condensate } \\
\text { production } \\
\text { (MCM) }\end{array}$ & $\begin{array}{c}\text { Condensate } \\
\text { RPP } \\
\text { (MCM) }\end{array}$ \\
\hline 5300 & Burgos Basin & 357 & NA & NA & 365 & 476 & 4 & 43 \\
\hline 5301 & Tampico-Misantla Basin & 21 & NA & NA & 4 & 12 & NA & LT1 \\
\hline 5302 & Veracruz Basin & 63 & NA & NA & 101 & 225 & LT1 & 4 \\
\hline 5304 & Saline-Comalcalco Basin & 9 & NA & NA & LT1 & 6 & NA & LT1 \\
\hline 5305 & Villahermosa Uplift & 20 & NA & NA & 41 & 58 & 17 & 19 \\
\hline 5306 & Macuspana Basin & 36 & NA & NA & 170 & 184 & LT1 & 17 \\
\hline 5307 & $\begin{array}{l}\text { Campeche-Sigsbee Salt } \\
\text { Basin }\end{array}$ & 2 & NA & NA & NA & 9 & NA & LT1 \\
\hline 5308 & Yucatán Platform & NA & NA & NA & NA & NA & NA & NA \\
\hline 5310 & $\begin{array}{l}\text { Sierra Madre de Chiapas- } \\
\text { Peten Foldbelt }\end{array}$ & 4 & NA & NA & NA & 4 & NA & 3 \\
\hline 5313 & $\begin{array}{l}\text { Sierra Madre Oriental } \\
\text { Foldbelt }\end{array}$ & NA & NA & NA & NA & NA & NA & NA \\
\hline 5314 & Jalisco-Oaxaca Platform & 1 & NA & NA & NA & W & NA & W \\
\hline 5321 & Coahuila Platform & 6 & NA & NA & NA & LT1 & NA & LT1 \\
\hline 5323 & Sabinas Basin & 33 & NA & NA & 19 & 21 & NA & LT1 \\
\hline 5332 & Salton Trough & 2 & NA & NA & NA & LT1 & NA & LT1 \\
\hline 5334 & Vizcaíno Basin & 2 & NA & NA & NA & LT1 & NA & LT1 \\
\hline 6010 & Takutu Basin & NA & NA & NA & NA & NA & NA & NA \\
\hline 6011 & Solimões Basin & 37 & NA & NA & LT1 & 66 & LT1 & 3 \\
\hline 6012 & Amazonas Basin & 10 & NA & NA & NA & 23 & NA & 1 \\
\hline 6016 & Parnaíba Basin & 19 & NA & NA & 3 & 57 & LT1 & LT1 \\
\hline 6020 & Paraná Basin & 11 & NA & NA & NA & 1 & NA & LT1 \\
\hline 6021 & Guyana-Suriname Basin & NA & NA & NA & NA & NA & NA & NA \\
\hline 6022 & Foz do Amazonas Basin & 6 & NA & NA & NA & 31 & NA & LT1 \\
\hline 6023 & Santana Platform & 1 & NA & NA & NA & W & NA & NA \\
\hline 6025 & Barreirinhas Basin & 4 & NA & NA & NA & 3 & NA & LT1 \\
\hline 6026 & Ceará Basin & 8 & NA & NA & NA & 3 & NA & LT1 \\
\hline 6027 & Potiguar Basin & 27 & NA & NA & 2 & 27 & LT1 & 3 \\
\hline 6029 & Sergipe-Alagoas Basin & 39 & NA & NA & 7 & 26 & LT1 & 2 \\
\hline 6031 & Tucano Basin & 4 & NA & NA & LT1 & LT1 & LT1 & LT1 \\
\hline 6032 & Recôncavo Basin & 41 & NA & NA & 24 & 49 & LT1 & 1 \\
\hline 6033 & Bahia Sul Basin & 7 & NA & NA & NA & 23 & NA & 2 \\
\hline 6034 & Espírito Santo Basin & 24 & NA & NA & 16 & 84 & 2 & 10 \\
\hline 6035 & Campos Basin & 16 & NA & NA & LT1 & 69 & NA & 64 \\
\hline 6036 & Santos Basin & 16 & NA & NA & 16 & 426 & 4 & 51 \\
\hline 6038 & Santiago Basin & 1 & NA & NA & NA & W & NA & W \\
\hline
\end{tabular}


Table 1-5. Cumulative production and recoverable proven plus probable resources of conventional hydrocarbon resources from gas-only fields, by petroleum province within Latin America and the Caribbean.-Continued

[Data derived from IHS International Exploration and Production Database; used with permission from IHS Global, Inc. ${ }^{1}$ (IHS Global Inc., 2016). Excludes extra-heavy crude and unconventional resources (coalbed methane, shale gas, tight gas, shale oil, and tight oil). Data for oil and condensate in million cubic meters (MCM); data for gas in billion cubic meters (BCM). LT1, less than one unit; NA, not available; RPP, recoverable proven plus probable resources; W, data withheld to conceal proprietary data. Data are rounded to no more than three significant digits; may not add to totals shown. Data are unrounded for grand total of number of fields]

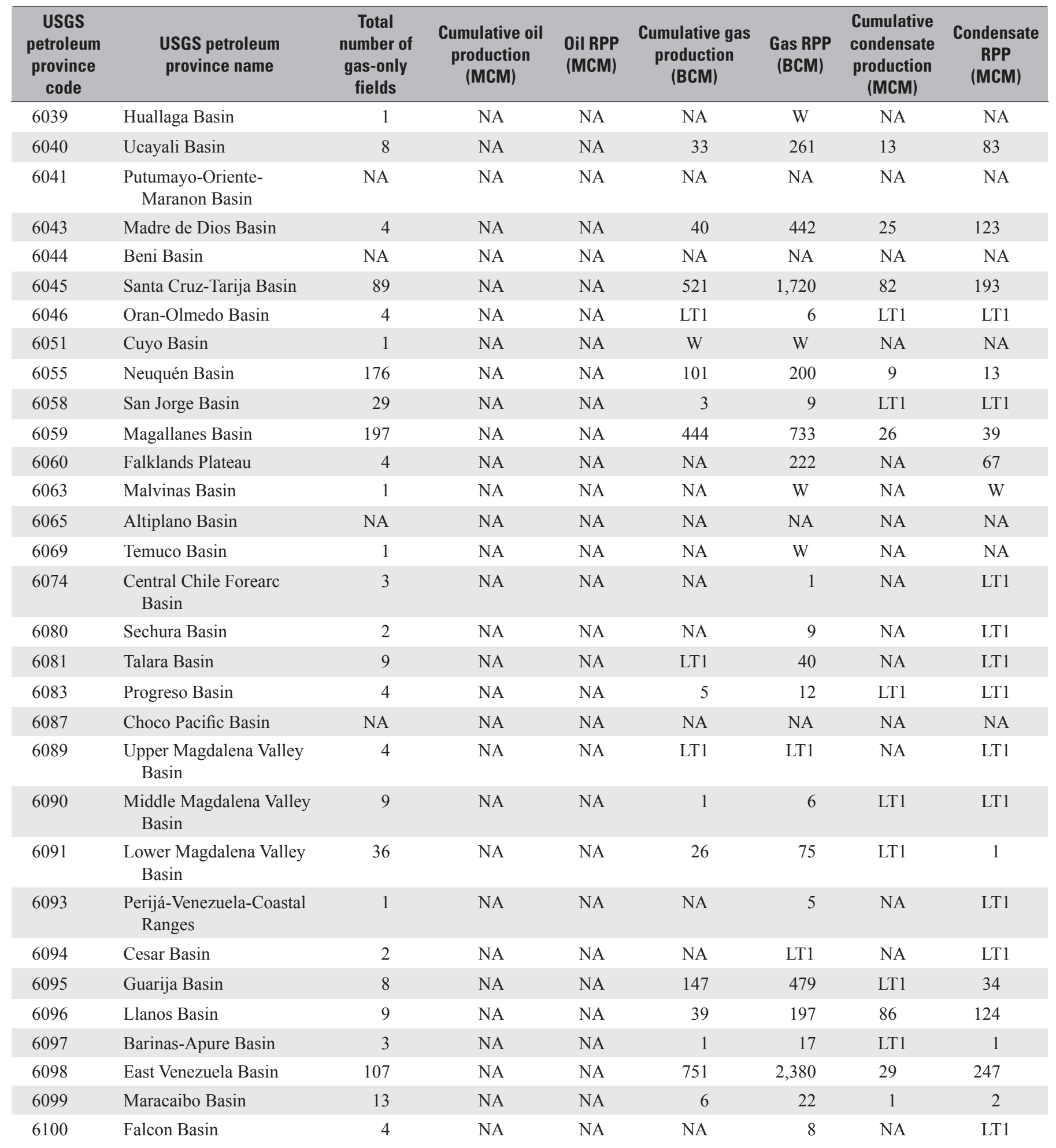


Table 1-5. Cumulative production and recoverable proven plus probable resources of conventional hydrocarbon resources from gas-only fields, by petroleum province within Latin America and the Caribbean.-Continued

[Data derived from IHS International Exploration and Production Database; used with permission from IHS Global, Inc. ${ }^{1}$ (IHS Global Inc., 2016). Excludes extra-heavy crude and unconventional resources (coalbed methane, shale gas, tight gas, shale oil, and tight oil). Data for oil and condensate in million cubic meters (MCM); data for gas in billion cubic meters (BCM). LT1, less than one unit; NA, not available; RPP, recoverable proven plus probable resources; W, data withheld to conceal proprietary data. Data are rounded to no more than three significant digits; may not add to totals shown. Data are unrounded for grand total of number of fields]

\begin{tabular}{|c|c|c|c|c|c|c|c|c|}
\hline $\begin{array}{l}\text { USGS } \\
\text { petroleum } \\
\text { province } \\
\text { code }\end{array}$ & $\begin{array}{l}\text { USGS petroleum } \\
\text { province name }\end{array}$ & $\begin{array}{l}\text { Total } \\
\text { number of } \\
\text { gas-only } \\
\text { fields }\end{array}$ & $\begin{array}{l}\text { Cumulative oil } \\
\text { production } \\
\text { (MCM) }\end{array}$ & $\begin{array}{l}\text { Oil RPP } \\
\text { (MCM) }\end{array}$ & $\begin{array}{l}\text { Cumulative gas } \\
\text { production } \\
\text { (BCM) }\end{array}$ & $\begin{array}{l}\text { Gas RPP } \\
\text { (BCM) }\end{array}$ & $\begin{array}{l}\text { Cumulative } \\
\text { condensate } \\
\text { production } \\
\text { (MCM) }\end{array}$ & $\begin{array}{c}\text { Condensate } \\
\text { RPP } \\
\text { (MCM) }\end{array}$ \\
\hline 6102 & Cariaco Basin & 3 & NA & NA & NA & 6 & NA & LT1 \\
\hline 6103 & Tobago Trough & 12 & NA & NA & 52 & 299 & LT1 & 9 \\
\hline 6104 & $\begin{array}{l}\text { South Caribbean } \\
\text { Deformed Belt }\end{array}$ & 1 & NA & NA & NA & W & NA & W \\
\hline 6106 & West-Central Cordillera & NA & NA & NA & NA & NA & NA & NA \\
\hline 6107 & $\begin{array}{l}\text { Lesser Antilles Deformed } \\
\text { Belt }\end{array}$ & 12 & NA & NA & LT1 & LT1 & LT1 & LT1 \\
\hline 6114 & North Nicaraguan Rise & NA & NA & NA & NA & NA & NA & NA \\
\hline 6117 & $\begin{array}{l}\text { Greater Antilles Deformed } \\
\text { Belt }\end{array}$ & NA & NA & NA & NA & NA & NA & NA \\
\hline
\end{tabular}

${ }^{1}$ In July 2016, the parent company of IHS Global, IHS Inc., merged with Markit Ltd. to become IHS Markit. These data were accessed and acquired in early 2016, prior to the finalization of this merger.

Table 1-6. Cumulative production and recoverable proven plus probable resources of extra-heavy crude from oil fields, by petroleum province within Latin America and the Caribbean.

[Data derived from IHS International Exploration and Production Database; used with permission from IHS Global, Inc. ${ }^{1}$ (IHS Global Inc., 2016). Excludes conventional and unconventional resources (coalbed methane, shale gas, tight gas, shale oil, and tight oil). Data for oil and condensate in million cubic meters (MCM); data for gas in billion cubic meters (BCM). LT1, less than one unit; NA, not available; RPP, recoverable proven plus probable resources; W, data withheld to conceal proprietary data. Data are rounded to no more than three significant digits; may not add to totals shown. Data are unrounded for grand total of number of fields]

\begin{tabular}{|c|c|c|c|c|c|c|c|c|}
\hline $\begin{array}{l}\text { USGS } \\
\text { petroleum } \\
\text { province } \\
\text { code }\end{array}$ & $\begin{array}{l}\text { USGS petroleum } \\
\text { province name }\end{array}$ & $\begin{array}{c}\text { Total } \\
\text { number } \\
\text { of oil } \\
\text { fields }\end{array}$ & $\begin{array}{l}\text { Cumulative oil } \\
\text { production } \\
\text { (MCM) }\end{array}$ & $\begin{array}{l}\text { Oil RPP } \\
\text { (MCM) }\end{array}$ & $\begin{array}{l}\text { Cumulative gas } \\
\text { production } \\
\text { (BCM) }\end{array}$ & $\begin{array}{l}\text { Gas RPP } \\
\text { (BCM) }\end{array}$ & $\begin{array}{c}\text { Cumulative } \\
\text { condensate } \\
\text { production } \\
\text { (MCM) }\end{array}$ & $\begin{array}{l}\text { Condensate } \\
\text { RPP } \\
\text { (MCM) }\end{array}$ \\
\hline 5304 & Saline-Comalcalco Basin & 3 & NA & 3 & NA & LT1 & NA & NA \\
\hline 5305 & Villahermosa Uplift & 10 & LT1 & 168 & LT1 & 3 & NA & NA \\
\hline 5307 & $\begin{array}{l}\text { Campeche-Sigsbee Salt } \\
\text { Basin }\end{array}$ & 5 & NA & 57 & NA & 2 & NA & NA \\
\hline 6036 & Santos Basin & 1 & NA & W & NA & W & NA & NA \\
\hline 6041 & $\begin{array}{l}\text { Putumayo-Oriente- } \\
\text { Maranon Basin }\end{array}$ & 3 & LT1 & 100 & NA & 1 & NA & NA \\
\hline 6096 & Llanos Basin & 4 & 1 & 47 & LT1 & LT1 & NA & NA \\
\hline 6098 & East Venezuela Basin & 34 & 566 & 42,800 & 17 & 627 & NA & NA \\
\hline Total & & 60 & 568 & $\mathbf{W}$ & 17 & $\mathbf{W}$ & NA & NA \\
\hline
\end{tabular}

${ }^{1}$ In July 2016, the parent company of IHS Global, IHS Inc., merged with Markit Ltd. to become IHS Markit. These data were accessed and acquired in early 2016 , prior to the finalization of this merger. 
Table 1-7. Cumulative production and recoverable proven plus probable resources of unconventional hydrocarbon resources from oil fields, by petroleum province within Latin America and the Caribbean.

[Data derived from IHS International Exploration and Production Database; used with permission from IHS Global, Inc. ${ }^{1}$ (IHS Global Inc., 2016). Excludes conventional and extra-heavy crude resources. Data for oil and condensate in million cubic meters (MCM); data for gas in billion cubic meters (BCM). LT1, less than one unit; NA, not available; RPP, recoverable proven plus probable resources; W, data withheld to conceal proprietary data. Data are rounded to no more than three significant digits; may not add to totals shown. Data are unrounded for grand total of number of fields]

\begin{tabular}{|c|c|c|c|c|c|c|c|c|}
\hline $\begin{array}{l}\text { USGS } \\
\text { petroleum } \\
\text { province } \\
\text { code }\end{array}$ & $\begin{array}{l}\text { USGS petroleum } \\
\text { province name }\end{array}$ & $\begin{array}{c}\text { Total } \\
\text { number of } \\
\text { oil fields }\end{array}$ & $\begin{array}{l}\text { Cumulative oil } \\
\text { production } \\
\text { (MCM) }\end{array}$ & $\begin{array}{l}\text { Oil RPP } \\
\text { (MCM) }\end{array}$ & $\begin{array}{l}\text { Cumulative gas } \\
\text { production } \\
\text { (BCM) }\end{array}$ & $\begin{array}{l}\text { Gas RPP } \\
\text { (BCM) }\end{array}$ & $\begin{array}{l}\text { Cumulative } \\
\text { condensate } \\
\text { production } \\
\text { (MCM) }\end{array}$ & $\begin{array}{c}\text { Condensate } \\
\text { RPP } \\
\text { (MCM) }\end{array}$ \\
\hline 5300 & Burgos Basin & 14 & LT1 & LT1 & LT1 & 16 & NA & LT1 \\
\hline 5323 & Sabinas Basin & 2 & NA & NA & 1 & 7 & NA & LT1 \\
\hline 6017 & São Francisco Basin & 1 & NA & NA & NA & $\mathrm{W}$ & NA & $\mathrm{W}$ \\
\hline 6055 & Neuquén Basin & 70 & 79 & 368 & 420 & 681 & 36 & 57 \\
\hline 6058 & San Jorge Basin & 7 & 83 & 117 & 23 & 35 & NA & 1 \\
\hline 6059 & Magallanes Basin & 10 & LT1 & 1 & 1 & 9 & LT1 & 2 \\
\hline 6060 & Falklands Plateau & 1 & NA & NA & NA & $\mathrm{W}$ & NA & $\mathrm{W}$ \\
\hline Total & & 115 & 162 & 486 & 446 & 785 & 36 & 61 \\
\hline
\end{tabular}

${ }^{1}$ In July 2016, the parent company of IHS Global, IHS Inc., merged with Markit Ltd. to become IHS Markit. These data were accessed and acquired in early 2016 , prior to the finalization of this merger. 


\section{Appendix 2-Case study 1: Iron ore mining and transportation infrastructure in Brazil's Iron Quadrangle}

\section{Geologic overview}

The Iron Quadrangle is a mountainous mining region located in the south-central part of the State of Minas Gerais, Brazil. The Iron Quadrangle is rich in iron ore, along with deposits of gold and manganese. Iron ore deposits in this area occur as a metamorphosed Precambrian banded iron formation, known as itabirite. Itabirite contains bands of hematite that range from millimeters to centimeters in thickness over long distances. Iron ore is extracted by open pit mining and the majority of the ore is concentrated locally. Further processing or pelletizing occurs locally at a few facilities, though a majority of material is processed near coastal ports (Dorr and Barbosa, 1963; Vale S.A., 2012a, p. 397).

\section{Country background}

In 2015, Brazil had a population of more than 200 million people and a land area of about 8.4 million $\mathrm{km}^{2}$. For the same year, Brazil was estimated to be the world's third largest producer of iron ore behind China and Australia, contributing about 13 percent of the world's total production. Iron ore accounted for over 87 percent of the country's mineral exports by value. Of the approximately $411 \mathrm{Mt}$ of iron ore produced in Brazil in 2014, nearly 72 percent of it was exported. The country's main export partners for iron ore were China, which accounted for 55 percent of Brazil's total iron ore exports, followed by Japan, South Korea, and the Netherlands, each accounting for less than 10 percent of Brazil's total iron exports (Tuck, 2016; Departamento Nacional de Produção Mineral, 2016, p. 9, 67).

\section{Historical perspective, pre-1950}

Interest in mining in the area of the Iron Quadrangle began with the discovery of gold in the region in the 1720s. It was not until the early 20th century that specific interest in the rich iron ore deposits of the region began to grow. In 1910, at the 11th International Geological Congress, the Geological and Mineralogical Service of Brazil presented a report identifying the locations of iron ore deposits in Minas Gerais and outlining their economic potential. For the first time, these deposits became internationally known, with the report garnering the attention of American and European mining companies (Dorr and Barbosa, 1963, p. C4; Vale S.A., 2012c, p. 27).

The first company to demonstrate interest in the iron ore deposits was the United Kingdom-based Brazilian Hematite Syndicate (BHS), which acquired 42,000 shares in the Estrada de Ferro Vitória a Minas (EFVM) railroad company in 1910. The BHS made a request to the Brazilian Government to change the route of the original railroad to include Itabira, the city closest to the deposits. After the request was granted, the BHS acquired nearly $77 \mathrm{~km}^{2}$ of land near Itabira which contained the major iron ore deposits known at the time, consisting of more than $1 \mathrm{Gt}$ of ore. The syndicate incorporated as the London-based Itabira Iron Ore Co., which in 1911 received authorization from the Brazilian Government to operate within the country.

Development, however, did not begin owing to the start of World War I, which cut the project off from potential funding from European sources. Following the war, the Itabira Iron Ore Co. signed a contract with the Brazilian Government granting the company the right to construct and operate mines in the Itabira region; however, ratification of the contract was delayed owing to internal nationalist opposition to the company. The global economic depression of the 1930s further restricted funding for the project, and in 1939 the government voided the contract with the company through Decree Law No. 1,507 (Vale S.A., 2012c, p. 29; 2012b).

In 1942, with fears that a German invasion of Spain and North Africa would cut off the United Kingdom's more proximal sources of iron ore, the United States, the United Kingdom, and Brazil signed the Washington Agreements. As part of these agreements, the British Government purchased Itabira Iron Ore Co. and EFVM and transferred the ownership to the Brazilian Government, which went on to form Companhia Vale do Rio Doce (CVRD), the precursor to Vale S.A. The role of CVRD was to manage EFVM and the mines originally owned by Itabira Iron Ore Co. The new company was divided into 85 percent public offering through shares and 15 percent private capital. Within nine years, CVRD became the leading exporter of iron ore in Brazil, increasing from 11 percent of total iron ore shipped in 1942 to over 81 percent in 1950. Total iron ore exports also greatly expanded for the country, from about 316,000 t exported in 1942 to 890,000 t exported in 1950 (Dorr and Barbosa, 1963, p. C5.; Vale S.A., 2012b). For comparison, approximately $296 \mathrm{Mt}$ of iron ore was exported from Brazil in 2014 (Departamento Nacional de Produção Mineral, 2016, p. 9, 67).

\section{Mineral production facilities, post-1950}

\section{Mines}

In 2014, nine companies were operating over 20 iron ore mines or mining complexes within the Iron Quadrangle 
(table 2-1, figure 2-1). Iron ore is extracted from open pit mines and transported either to pelletizing plants or directly to ports for export. The largest producing among these companies is Vale S.A., which operates six mining complexes within the Iron Quadrangle and has produced ore from more than 19 mines during the course of the company's operating history in the region.

Vale's six mining complexes are the Itabira, Itabirito, Mariana, Minas Centrais, Paraopeba, and Vargem Grande complexes, which are subsequently organized into two systems, the Southeastern System (Itabira, Minas Centrais, and Mariana complexes) and the Southern System (Itabirito, Paraopeba, and Vargem Grande complexes). Proven and probable iron ore $\left(\mathrm{Fe}_{2} \mathrm{O}_{3}\right)$ reserves total nearly $5.5 \mathrm{Gt}$ at an average 44 percent grade in the Southern System and 5.0 Gt at an average 46 percent grade in the Southeastern System. In 2015, Vale reported that its mines in the Iron Quadrangle accounted for about 60 percent of the company's annual iron ore production of $333 \mathrm{Mt}$ from Brazil (note: this total does not include production from Samarco, of which Vale owns a 50 percent interest;Vale S.A., 2016a, p. 27-28, 65; 2016b).

Samarco Mineração S.A., jointly owned by Vale ( 50 percent) and BHP Billiton plc (50 percent, Australia), operates the Alegria Mine and Germano concentrator, which have an annual capacity to process $22 \mathrm{Mt}$ of iron ore. Operations at the Germano Mine commenced in 1977, but have since closed owing to depletion of ore in 1991. The Alegria Mine, which commenced production in 1992, supplies the Germano concentrator with iron ore. Vale acquired 50 percent of Samarco in 2000 through its acquisition of S.A. Mineração da Trindade (Samitri). At the time of the acquisition Samarco was jointly controlled by Samitri (5 percent) and BHP Billiton
(49 percent). As part of the Vale acquisition, Samitri sold 1 percent of its share of Samarco to BHP Billiton, equalizing the partner's ownership interests (BHP Billiton Ltd., 2002, p. 28; Vale Overseas Ltd., 2002, p. 16; Vale S.A, 2016b).

Mineração Usiminas S.A. [Usinas Siderúrgicas de Minas Gerais S.A. (Usiminas), 70 percent and Sumitomo Corp., 30 percent] operates four mines in the western section of the Iron Quadrangle, known as the Serra Azul region, with a combined annual capacity of $12 \mathrm{Mt}$ of iron ore. Usiminas acquired the mines in the region through its 2008 acquisition of Brazilian mining companies Siderúrgica Oeste de Minas Ltda. and Global Mineração Ltda. Usiminas formed Mineracao Usiminas S.A. in 2010 as a partnership with Sumitomo Corp. (Usinas Siderúrgicas de Minas Gerais S.A., 2009, p. 38; 2011, p. 10). MMX Mineração e Metálicos S.A. owns and operates two mines within the Serra Azul region of the Iron Quadrangle: the Tico-Tico and Ipe mines. MMX acquired the Tico-Tico Mine in 2007 and the Ipe Mine in 2008 (MMX Mineração e Metálicos S.A, undated).

\section{Pelletizing plants}

Vale operates two pelletizing plants located within the Iron Quadrangle, one at the Itabiritos complex, known as the Fabrica pelletizing plant, and the other at the Vargem complex, known as Vargem Grande. Vale also owns eight pelletizing plants located at its port of Tubarão in Espírito State, which processes ore sourced from Vale's Southeastern System mines. Samarco operates three pelletizing plants located at the Port of Ubu (Ponta Ubu), Espírito Santo State. The pelletizing plants at Ponta Ubu process ore sourced from Samarco mining operations in the Iron Quadrangle. Companhia Hispano-Brasileira

Table 2-1. Iron ore mining companies within the Iron Quadrangle region, Minas Gerais, Brazil.

$[\%$, percent $]$

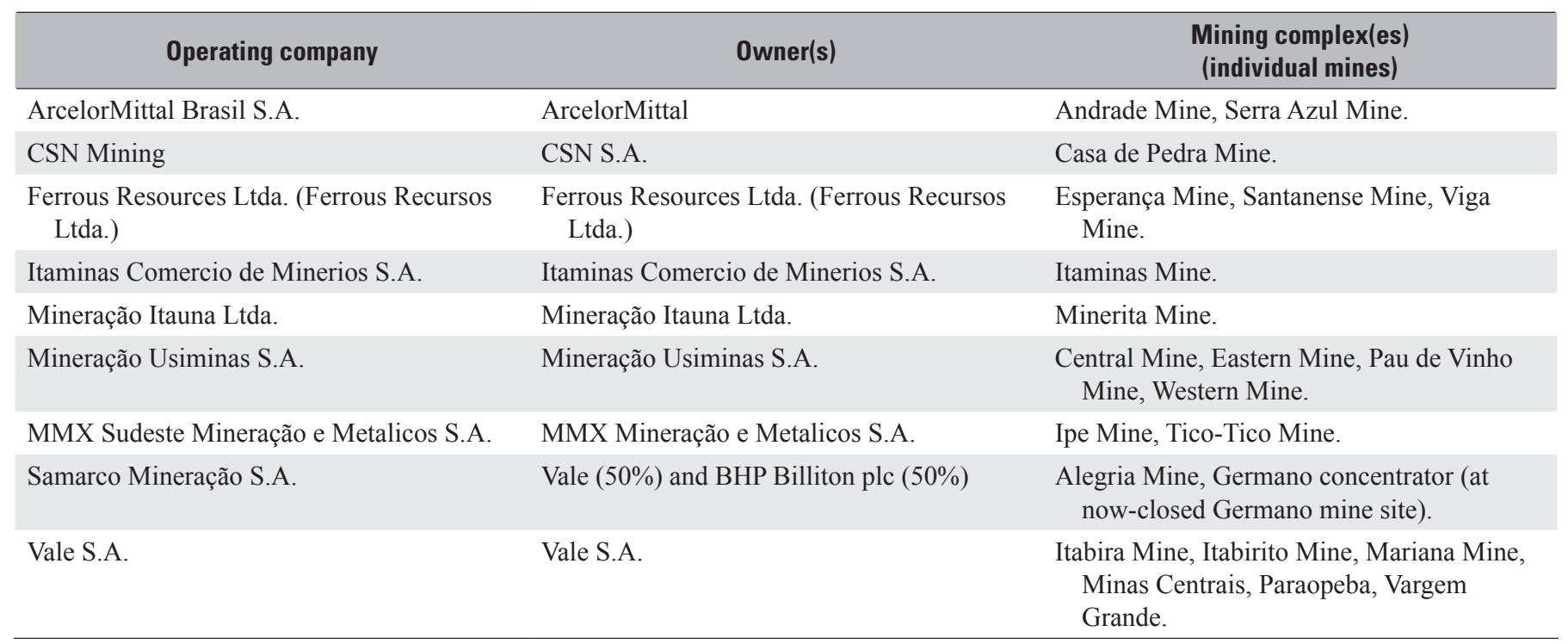




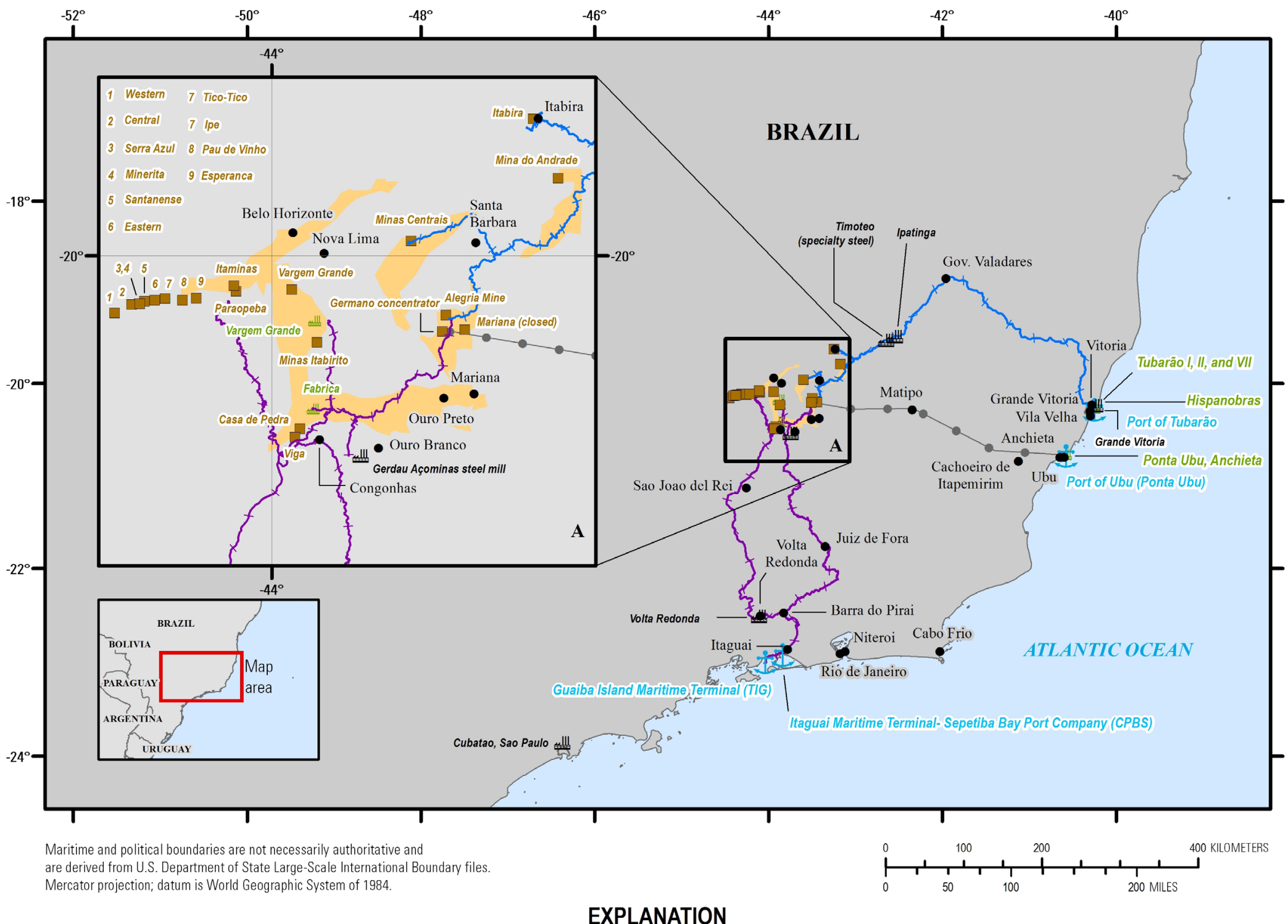

$\begin{array}{lll}\text { Mineral production } & \text { Other } & \text { Transportation infrastructure } \\ \text { Iron ore mine } & -\quad \text { City } & \text { Iron ore } \\ \text { deposit area } & - \text { Sort } \\ \text { Pelletizing plant } & & - \text { Malha Regional Sudeste (MRS) Logisitca railroad } \\ \text { Steel mill } & & \text { Estrada de Ferro Vitória a Minas (EFVM) railroad }\end{array}$

Figure 2-1. Overview map of iron ore mines, pelletizing plants, steel mills, and associated transportation infrastructure in the Iron Quadrangle, Minas Gerais, Brazil, 2015. 
de Pelotização S.A (HISPANOBRAS), jointly owned by Vale (50.9 percent) and ArcelorMittal (49.1 percent), operates a pelletizing plant in Vitória, Espírito Santo State, adjacent to the port of Tubarão (Companhia Hispano-Brasileira de Pelotização S.A., 2014, p. 7; Vale S.A., 2016c, p. 30; 2016b).

\section{Transportation infrastructure}

Two railroad companies serve the iron ore industry in the Iron Quadrangle region, the EFVM and MRS Logística S.A. Vale operates EFVM under a 30-year renewable concession that expires in 2027. Iron ore sourced from Vale's Southeastern System mines is transported by EFVM to Vale's pelletizing plants in Vitória. The EFVM also transports port passengers from Vitória to the capital of Minas Gerais, Belo Horizonte (Vale S.A., 2016a, p. 56; 2016b). MRS Logística is owned by a partnership between Companhia Siderúrgica Nacional S.A. (CSN), Gerdau S.A., Usiminas Particpacoes e Logística (subsidiary of Mineração Usiminas), and Vale. The MRS Logística railway connects iron ore facilities in the Iron Quadrangle to ports in Rio de Janerio State. Iron ore and pellets from Vale's Southern System mines are transported via the MRS Logística railway to Vale's Guaiba Island Maritime Terminal and the Itaguai Maritime Terminal (operated by
Vale's wholly owned subsidiary Cia. Portuaria Baia Sepetiba). MRS Logística transports ore sourced by CSN's Casa de Pedra Mine to CSN's fully owned terminal located adjacent to Vale's Itaguai Maritime Terminal. Ore sourced from MMX-owned mines is also transported to the CSN-owned terminal, as well as to the newly opened terminal operated by Porto Sudeste do Brasil S.A., jointly owned by a partnership between Impala Terminals (wholly owned subsidiaries of Trafigura Group) and Mubadala Development Company PJSC (65 percent) and MMX (35 percent) (MMX Mineração e Metálicos S.A, undated; Porto Sudeste do Brasil S.A., 2016; Vale S.A., 2016a, p. 27-28).

Iron ore sourced from Samarco's Alegria Mine is first transported for grinding to the nearby Germano concentrator. The ore is then transported more than $350 \mathrm{~km}$ using three separate underground slurry pipes that connect the Germano concentrator and Samarco's pelletizing plants at Ponta Ubu. The first of these pipelines was installed in 1977; construction on the second pipeline began in 2005 and was completed in 2008. A third pipeline was installed in 2014 as the production of the Samarco mining operations continued to expand (Ausenco Ltd., 2016; Samarco Mineração S.A., 2016; Vale S.A., 2016a, p. 28). Slurry pipelines were significantly damaged in the Fundão tailings dam collapse in November 2015 (McCrae, 2016). 


\section{Appendix 3-Case study 2: Bauxite mining and alumina production in Jamaica}

\section{Geologic overview}

The USGS classified bauxite deposits in Jamaica as pocket deposits, which are defined primarily as the fillings within depressions in limestones or dolomites that vary greatly in both shape and size. The irregularly shaped bauxite deposits have diameters that range from $15 \mathrm{~m}$ to more than $100 \mathrm{~m}$ and thicknesses that range from less than $1 \mathrm{~m}$ to more than $30 \mathrm{~m}$. The soils overlying these pocket deposits are rarely more than $1 \mathrm{~m}$ thick and can easily be stripped away without the use of drilling and blasting. The pocket deposits in Jamaica formed over the undulating surface of the White Limestone Formation, with bauxite filling sinkholes and extending over limestone ridges between sinkhole formations (Patterson and others, 1986, p. B10, B17-B18, B52-B53).

\section{Country background}

Bauxite production in Jamaica began in 1952, and within six years the country became the world's leading bauxite producer. In 2015, Jamaica ranked sixth in world bauxite production, producing about $10.7 \mathrm{Mt}$, which accounted for about 4 percent of the world's total bauxite production. Bauxite reserves in Jamaica were estimated to be about 2 Gt in 2015, which ranks Jamaica second in the Latin America and Caribbean region, behind Brazil, and fifth in the world. Jamaica produced about $1.95 \mathrm{Mt}$ of alumina in 2015, which accounted for about 1.7 percent of the world's alumina production.

Companies engaged in the production of bauxite and alumina in Jamaica include (1) Jamaica Aluminum Co. (Jamalco), which is 55 percent owned by Noble Group Ltd. of China and 45 percent owned by Clarendon Alumina Production (wholly owned by the Government of Jamaica); (2) Noranda Jamaica Bauxite Partners LLC, owned 51 percent by the Government of Jamaica and 49 percent by Noranda Aluminum Holding Corp. of Canada; and (3) United Company RUSAL of Russia through its two wholly owned subsidiaries, Alumina Partners of Jamaica (Alpart) and West Indies Alumina Co. (Windalco) (Bray, 2016c, p. 10.13; Jamaica Bauxite Institute, 2015b; Patterson and others, 1986, p. B52; Soto-Viruet, 2015a, p. 13.8; United Company RUSAL Plc, 2015).

All of Jamaica's bauxite and alumina is exported, as the country does not have the infrastructure to support the production of primary aluminum metal. The value of bauxite and alumina exports from Jamaica in 2015 was about $\$ 130$ million and $\$ 542$ million, respectively. Together, bauxite and alumina exports accounted for 53 percent of Jamaica's total value of exports in 2015, up from 46 percent in 2014 and 41 percent in 2013 (Bank of Jamaica, 2016, p. 2).

\section{Historical perspective}

Bauxite in Jamaica was first identified in the late 1930s on a farm in Lydford, St. Ann Parish, when soil fertility tests indicated the soil was highly aluminous. This discovery triggered an interest by European and North American aluminum companies. The first company to explore Jamaica for bauxite following the initial discovery was the Aluminum Co. of Canada, Ltd. (now Rio Tinto Alcan, Inc.). The Aluminum Co. of Canada constructed the Kirkvine Works, Jamaica's first alumina refinery, in 1952, and the country's second alumina refinery, the Ewarton Works, in 1959. United States-based companies Reynolds Metals Co. (acquired by Alcoa Inc. in 2000) and Kaiser Aluminum Corp. began exporting bauxite from a port in Ocho Rios on the eastern coast of St. Ann Parish in 1952 and from Port Kaiser in 1953, respectively. The Ocho Rios port is no longer operational, with the only northern coast transportation infrastructure located at Discovery Bay/Port Rhoades.

In 1957, five years after the opening of the Kirkvine Works, Jamaica had become the world's largest producer of bauxite and alumina. Alcoa was the fourth company to enter the bauxite and alumina market and began exporting bauxite in 1961. In 1969, Alumina Partners of Jamaica (Alpart) was established as a partnership between Kaiser Aluminum, Reynolds Metals, and the Anaconda Copper Mining Co., and commissioned the construction of the Nain alumina refinery. Revere Copper and Brass Co. constructed the country's fourth alumina refinery in Maggotty, St. Elizabeth Parish, in 1971. Alcoa constructed the Halse Hall refinery in 1973 (also known as the Clarendon Alumina Works), the fifth alumina refinery to operate in Jamaica. Jamaica stayed first in world production until 1971 (Jamaica Bauxite Institute, 2015d; Wilmot and others, 1959).

In the 1970s the Jamaican Government established (1) Jamaica Bauxite Mining (JBM), for the purpose of holding assets acquired from government/private partnerships and joint ventures; (2) the Jamaica Bauxite Institute (JBI), for the purpose of advising, monitoring, and implementing policies on all aspects of the bauxite and alumina industry; and (3) the Bauxite and Alumina Trading Co., for the purpose of carrying out all trading activities on behalf of governmentowned entities. Jamalco was formed in 1976, as a partnership between Alcoa (94 percent) and JBM (6 percent), and began to export bauxite through the port at Rocky Point in Clarendon Parish. The Jamaican Government formed Clarendon Alumina Production (CAP) in 1988 and acquired 44 percent of Alcoa's shares of Jamalco in order to continue operations at the Halse Hall/Clarendon refinery, which had closed in the same year. In 1985, the Jamaican Government acquired 
Reynolds Metals operations, which had closed in 1984. The Alpart operation closed in 1985, but reopened in 1988 under a new joint venture between Kaiser Aluminum (65 percent) and Norwegian-based Hydro Aluminum (35 percent). In 2001, Glencore International AG of Switzerland acquired Alcan Inc.'s (formerly Aluminum Company of Canada) 93-percent share in the Ewarton and Kirkvine alumina refineries, with the remaining 7 percent owned by JBM. JBM and Glencore formed the joint venture West Indies Alumina Co. (Windalco) to manage the Ewarton and Kirkvine refineries and the bauxite mines in Russell Place and Schwallenburgh (Bermúdez-Lugo, 2004). In 2007, RUSAL acquired Glencore's 93 percent share in Windalco and in 2014 acquired JBM's remaining 7 percent share in Windalco (Jamaica Bauxite Institute, 2015c-d; The Gleaner, 2014). In 2014, Alcoa World Alumina and Chemicals (AWAC) completed the sale of its 55-percent interest in Jamalco to Noble Group Ltd. of China, after receiving all regulatory approvals; AWAC would remain the managing operator until 2017 (Alcoa Inc., 2014).

\section{Mineral production facilities and transportation infrastructure}

\section{Mines and alumina refineries}

The majority of bauxite mining in Jamaica takes place in Manchester and St. Ann parishes, with some mining extending into the adjacent St. Elizabeth and St. Catherine parishes (figure 3-1).

Bauxite ore is hauled by truck and conveyor belt from mining sites and then transported to a domestic alumina refinery or transported by rail directly to a port for export. As of 2016, there were four alumina refineries having the physical infrastructure to process bauxite into alumina; however, not all were operational. The Ewarton Works in St. Catherine Parish (operated by Windalco) and the Clarendon Alumina Works in Clarendon Parish (operated by Jamalco) were both in operation. Windalco's Kirkvine Works has been suspended from processing alumina since 2009. The fourth alumina refinery, at Nain in St. Elizabeth Parish-sometimes referred to as the Alpart refinery — closed in 2009 and was sold to Jinquan Iron and Steel Co. in 2016 (The Gleaner, 2016).

Bauxite and alumina are exported from Jamaica by way of four ports, three on the southern coast and one on the northern coast. In the south, rail lines transport (1) bauxite and alumina produced by Windalco to Port Esquivel in St. Catherine Parish, (2) alumina produced by Jamalco's Clarendon Alumina Works to Rocky Point port in Clarendon Parish, and (3) bauxite mined by Alpart near Nain to Port Kaiser in St. Elizabeth Parish. In the north, bauxite mined by Noranda at the St. Ann bauxite operation is transported by rail to Discovery Bay/Port Rhoades (Jamaica Bauxite Institute, 2015a-b; Myers, 2015; Patterson and others, 1986, p. B10).

The St. Ann bauxite mining operation in St. Ann Parish, operated by Noranda, has the capacity to produce $5.4 \mathrm{Mt}$ (dry) of bauxite per year. Noranda reports that the mining at the operation is performed primarily by contracted third parties furnishing their own equipment. About $2.6 \mathrm{Mt}$ of the bauxite mined annually at the St. Ann operation is exported to Noranda's alumina refinery at Gramercy, Louisiana, United States, while the remaining bauxite is sold to third parties (Jamaica Bauxite Institute, 2015a; Noranda Aluminum Holding Corp., 2015, p. 2, 9).

RUSAL's wholly owned subsidiary, Alpart, operates a bauxite mine near Nain, St. Elizabeth Parish, having an annual capacity of 4.9 Mt. Operations at this mine resumed in 2015 following the 2009 closure of the mine and adjacent refinery, also owned by Alpart. The inactive Alpart alumina refinery in Nain had an annual capacity of $1.65 \mathrm{Mt}$. Bauxite mined by Alpart is exported to RUSAL's Nikolaev alumina refinery in Ukraine. RUSAL's other wholly owned subsidiary in Jamaica, Windalco, operates the Ewarton Works and Kirkvine Works alumina refineries, which have a combined annual capacity of 1.21 Mt. Bauxite is supplied to these refineries by two Windalco-owned and -operated mines, the Russell Place Mine and the Schwallenburgh Mine. The Russell Place Mine supplies the adjacent Kirkvine Works, while the Schwallenburgh Mine, which extends northward into St. Ann Parish, supplies the Ewarton Works. These two bauxite mines have a combined annual capacity of $4 \mathrm{Mt}$ (Jamaica Bauxite Institute, 2015b; Myers, 2015; United Company RUSAL Plc, 2016, p. 23-24).

The Clarendon Alumina Works in Halse Hall, Clarendon Parish, operated by Jamalco, has an annual capacity of about 1.4 Mt. Bauxite is supplied to the refinery via rail from Jamalco's Manchester Mine in south Manchester Parish. Alumina produced by the refinery is then transported about $20 \mathrm{~km}$ by rail to the Rocky Point port in Clarendon Parish, where it is exported to Canada, Iceland, and mainland Europe (Jamalco Inc., 2014; Noble Group, Ltd., 2016, p. 31-33). 


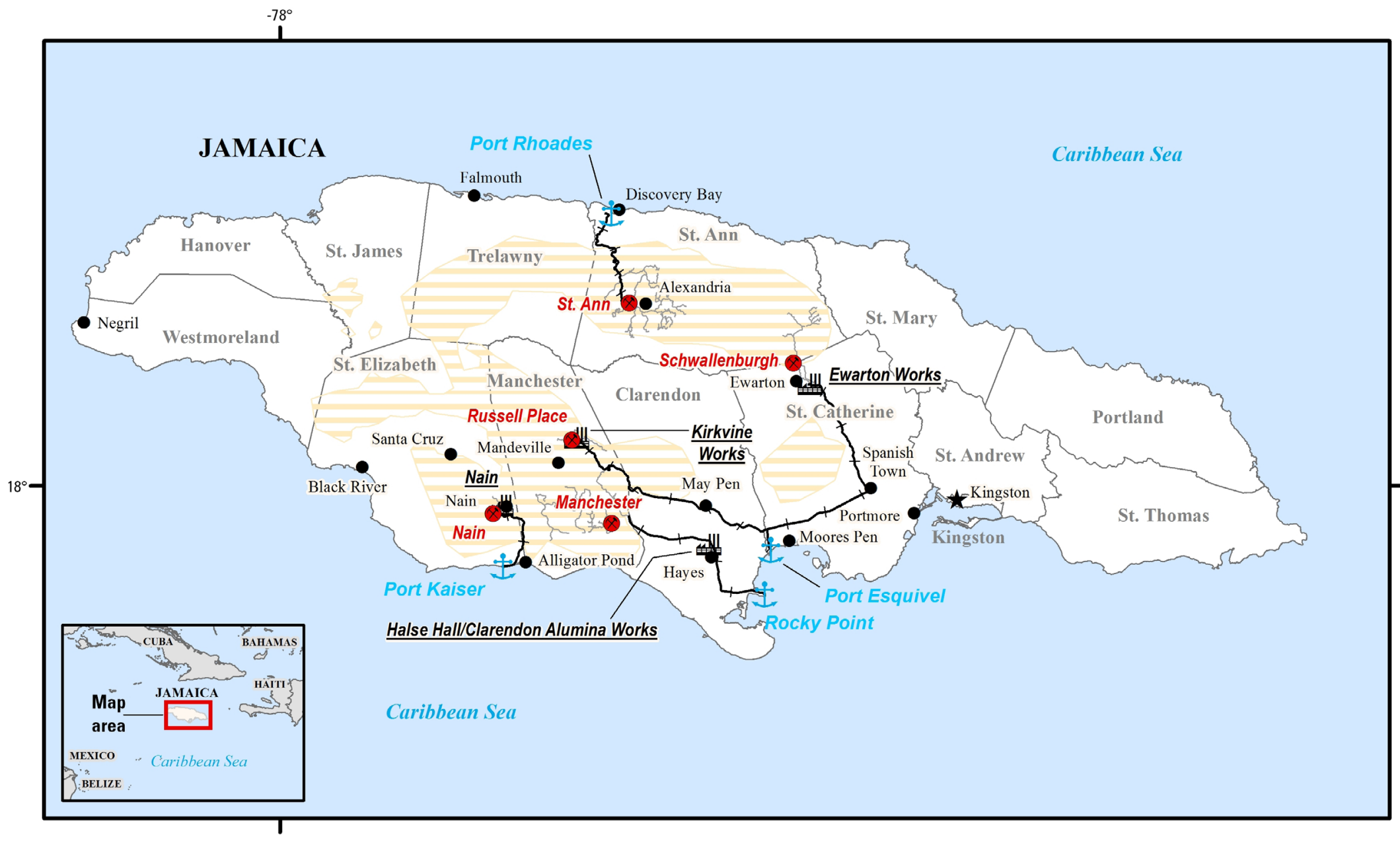

Parish boundaries from open-source files from University of Minnesota. Political boundaries are not necessarily authoritative.

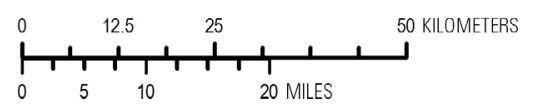

Mercator projection; datum is World Geographic System of 1984.

\section{EXPLANATION}

Mineral production

Other
- Bauxite mine

씨 Alumina refinery

$\begin{array}{lll}\text { - City } & \text { Bauxite deposit area } \\ \star & \text { Capital } & \square \text { Parish boundary }\end{array}$

$\underline{\text { Transportation infrastructure }}$

$$
\begin{aligned}
& \pm \text { Port } \\
& + \text { Railroad }
\end{aligned}
$$

- Mining area road

Figure 3-1. Overview map of bauxite mines and alumina refineries in Jamaica, 2016, showing associated transportation infrastructure. 

Manuscript approved on June 21, 2017

For more information about this publication contact: National Minerals Information Center

U.S. Geological Survey

12201 Sunrise Valley Drive

988 National Center

Reston, VA 20192

Email: nmicrecordsmgt@usgs.gov

For additional information visit https://minerals.usgs.gov/minerals

Prepared by the U.S. Geological Survey Science Publishing Network Reston Publishing Service Center

Edited by James R. Estabrook

Layout by Kay P. Naugle

Web support by Angela E. Hall 
